
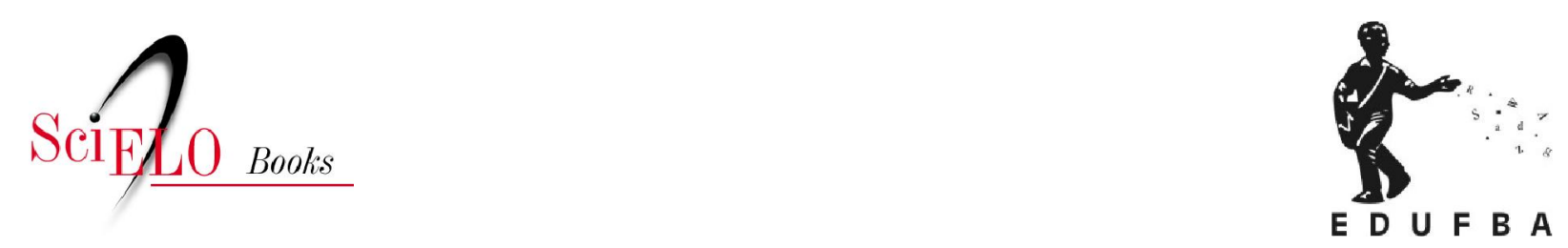

\title{
Como anda Salvador e sua região metropolitana
}

\author{
Inaiá Maia Moreira de Carvalho \\ Gilberto Corso Pereira \\ (orgs.)
}

\section{SciELO Books / SciELO Livros / SciELO Libros}

CARVALHO, IMM., and PEREIRA, GC., orgs. Como anda Salvador e sua região metropolitana [online]. 2nd ed. rev. and enl. Salvador: EDUFBA, 2008. 228 p. ISBN 978-85-232-0909-4. Available

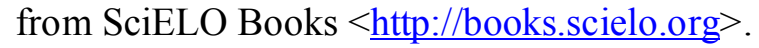

\section{(c)}

All the contents of this chapter, except where otherwise noted, is licensed under a Creative Commons Attribution-Non Commercial-ShareAlike 3.0 Unported.

Todo o conteúdo deste capítulo, exceto quando houver ressalva, é publicado sob a licença Creative Commons Atribuição - Uso Não Comercial - Partilha nos Mesmos Termos 3.0 Não adaptada.

Todo el contenido de este capítulo, excepto donde se indique lo contrario, está bajo licencia de la licencia Creative Commons Reconocimento-NoComercial-CompartirIgual 3.0 Unported. 
Inaiá Maria Moreira de Carvalho

Gilberto Corso Pereira

Organizadores

\section{COMO ANDA SALVADOR e sua Região Metropolitana}

$2^{\mathrm{a}}$ edição, revista e ampliada

Salvador - 2008

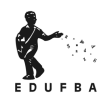


UNIVERSIDADE FEDERAL DA BAHIA

Reitor

Naomar de Almeida Filho

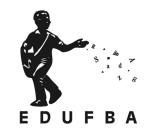

Editora da UFBA

DIRETORA

Flávia M. Garcia Rosa

CONSELHO EDITORIAL

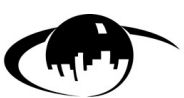

OBSERVATÓRIO DAS METRÓPOLES

Angelo Szaniecki Perret Serpa

Carmen Fontes Teixeira

Dante Eustachio Lucchesi Ramacciotti

Fernando da Rocha Peres

Maria Vidal de Negreiros Camargo

Sérgio Coelho Borges Farias

\section{SUPLENTES}

Bouzid Izerrougene

Cleise Furtado Mendes

José Fernandes Silva Andrade

Nancy Elizabeth Odonne

Olival Freire Júnior

Silvia Lúcia Ferreira
Revisão de linguagem

Dina Beck

Normalização

Neuza Nunes

Projeto gráfico, editoração e produção gráfica

Dadá Marques

Capa

Pasqualino Magnavita

Os trabalhos que compõem este livro foram elaborados com o apoio do

PRONEX, FAPESB/CNPq e do Instituto do Milênio.

C735

Como anda Salvador e sua Região Metropolitana/ organização

Inaiá Maia Moreira de Carvalho; Gilberto Corso Pereira -

Salvador; Edufba, 2008. 228 p.: grafs; mapas.

ISBN: 85-232-0393-1

1. Salvador (BA) 2. Região Metropolitana de Salvador (BA)

3. Metrópoles 4. Dinâmica Metropolitana I Carvalho, Inaiá Maria

Moreira de Carvalho II Pereira Gilberto Corso.

$\mathrm{CDU}=711.4(813.8)$ 
Para Milton Santos e Maria Brandão, por suas contribuições ao conhecimento de Salvador 



\section{NOTA DOS ORGANIZADORES}

Publicada em 2006, a primeira edição deste livro teve uma acolhida generosa e esgotou-se rapidamente. Esta segunda edição mantém os seus propósitos originais de alcançar tanto a academia como um público mais amplo, mas não 0 mesmo conteúdo. Os capítulos sobre a evolução da economia de Salvador e a formação de sua área metropolitana, sobre as condições demográficas e sobre as condições de vida, violências e extermínio, de autoria dos professores Paulo Henrique de Almeida, Cláudia Monteiro Fernandes e Jairnilson Paim, não chegaram a sofrer alterações. Mas, com a continuidade e o avanço dos trabalhos de pesquisa sobre a RMS, tornou-se possível aprofundar e atualizar as discussões referentes à segregação e dinâmica metropolitanas, às condições de ocupação e renda, habitação e infraestrutura, assim como às condições institucionais de cooperação entre os municípios que compõem a RMS, desenvolvidas pelos professores Gilberto Corso Pereira, Inaiá Carvalho e Celina Souza. Além disso, o livro foi enriquecido com mais dois capítulos, abordando a questão dos espaços públicos e o impacto do setor imobiliário turístico na conformação mais recente da região, de autoria dos professores Ângelo Serpa, Sylvio Bandeira de Mello e Silva, Barbara-Christine Nentwig Silva e Silvana Sá de Carvalho.

Ressaltando a importância dos estudos do Observatório das Metrópoles e da colaboração entre os seus pesquisadores para o avanço do conhecimento da realidade dessas regiões, renovamos, nesta oportunidade, os agradecimentos ao CNPq e a FAPESB, pelo apoio que viabilizou os estudos cujos resultados são apresentados nesta ocasião. 



\section{SUMÁRIO}

\section{Apresentação}

13 A Economia de Salvador e a Formação de sua Região Metropolitana Paulo Henrique de Almeida

53 Condições Demográficas

Cláudia Monteiro Fernandes

81 As "Cidades"de Salvador

Inaiá Maria Moreira de Carvalho

Gilberto Corso Pereira

109 Trabalho, Renda e Pobreza na Região Metropolitana de Salvador Inaiá Maria Moreira de Carvalho

137 Habitação e Infra-Estrutura Urbana em Salvador e Região Metropolitana Gilberto Corso Pereira

157 Condições de Vida, Violências e Extermínio Jairnilson Silva Paim

173 Os Espaços Públicos da Salvador Contemporânea Angelo Serpa

189 Metropolização e Turismo no Litoral Norte de Salvador: de um deserto a um território de enclaves?

Sylvio Bandeira de Mello e Silva

Barbara-Christine Nentwig Silva

Silvana Sá de Carvalho

213 Cooperação e Coordenação na Região Metropolitana de Salvador: o contexto institucional

Celina Souza 



\title{
APRESENTAÇÃO
}

\section{REGIÃO METROPOLITANA DE SALVADOR: espaço de refúgio, espaço de esperança}

\author{
Ana Fernandes* \\ Paulo Fábio Dantas Neto**
}

Desde a edição, há mais de duas décadas, de Bahia de Todos os Pobres, ${ }^{1}$ os interessados em conhecer mais e melhor a atualidade dos problemas sócio-urbanos de Salvador e de sua Região Metropolitana e em divisar suas perspectivas de equacionamento e solução ressentiam-se, para tal mister, de uma reflexão informada e informativa, a um só tempo densa - pelo conhecimento interdisciplinar em que se funda - e exposta de modo acessível ao entendimento e ao conseqüente uso por públicos internos e externos à academia.

Guardadas as diferenças de escopo e de circunstâncias, a presente coletânea, organizada por Inaiá Carvalho e Gilberto Corso Pereira, ao reunir trabalhos, individuais ou em parceria, deles próprios e de mais seis pesquisadores de áreas de conhecimento diversas, mas intelectualmente articulados para dar respostas ao requerimento acima indicado, corresponde plenamente ao que uma universidade pública merecedora desse nome deve almejar: usar recursos públicos para pesquisar

* Professora da Faculdade de Arquitetura da UFBa e presidente da Associação Nacional de PósGraduação e Pesquisa em Planejamento Urbano e Regional - ANPUR para a gestão 2005-2007.

** Professor do Departamento de Ciência Política da UFBA e Diretor do Centro de Recursos Humanos da UFBA.

${ }^{1}$ Coletânea organizada por Guaraci Adeodato de Sousa e Vilmar Faria, publicada, em 1980, pela Editora Vozes, reunindo, em perspectiva interdisciplinar, trabalhos de diversos pesquisadores, resultados de uma ampla pesquisa realizada conjuntamente pela UFBA/CRH e o Centro Brasileiro de Planejamento (CEBRAP). 
com ousadia, para transmitir o conhecimento adquirido com clareza e eficácia a quem pode continuar a buscá-lo e para difundi-lo mais amplamente, como forma de prestação de contas e de retribuição direta à sociedade pelo investimento.

Por este motivo, o Centro de Recursos Humanos da Faculdade de Filosofia e Ciências Humanas e o Programa de Pós-Graduação em Arquitetura e Urbanismo da Faculdade de Arquitetura sentem-se, como toda a UFBA, honrados e orgulhosos em apresentar à comunidade universitária e à sociedade baiana, tão relevante trabalho. $E$ assinalam, por dever de justiça e inspirados no reconhecimento manifestado pelos autores, a importância do PRONEX/CNPq/FAPESB, como programa financiador do projeto de pesquisa Metropóles, Desigualdades Sócio-Espaciais e Governança em Salvador (integrado ao Observatório das Metrópoles), do qual o presente livro é um dos resultados.

Estamos conscientes da dureza e da dramaticidade dos dados aqui mostrados, interpretados e analisados e não temos ilusões a respeito de fáceis e rápidas soluções para questões de longevos antecedentes e de complexidade sistêmica. Mas declaramos a conviç̧ão de que estudos como os que aqui se apresentam, ao lançarem luz sobre chagas sociais abertas, contribuem para a busca de caminhos que levem ao seu enfrentamento, ainda que não obriguem os seus usuários a uma concordância necessária com todas as interpretações, diagnósticos, argumentos e indicações de políticas aqui apresentados. Antes de tudo, este conjunto de estudos é um testemunho do enriquecimento de um saber sobre nossa região, 0 que equivale também a dizer que, depois dele, saberemos mais sobre nós mesmos.

Temos consciência de que as metrópoles sub-desenvolvidas se tornaram o grande refúgio das populações desassistidas do terceiro mundo. A concentração da pobreza na metrópole, tema por diversas vezes percorrido pelo prof. Milton Santos, se explicita a cada dia e se combina, no Brasil, com a criação de novas concentrações urbanas, novas realidades metropolitanas, sobretudo em realidades econômicas mais dinâmicas (a jusante do processo, como sua decorrência) ou em contextos institucionais mais agressivos (a montante do processo, como sua indução).

Os contornos da urbanização na Bahia e a ausência de políticas urbanas claramente definidas - em que pese o aumento de dinâmica de algumas áreas urbanas e a existência de zonas de atração inter-estadual - resultam na incapacidade de constituição, até o momento, de novas polaridades metropolitanas - nem por decorrência, nem por indução - que pudessem dividir com Salvador a forte polarização que sua região mantém sobre o território do Estado.

Fruto de modelos de ocupação territorial em rede centralizada, de seqüenciadas políticas econômicas indutoras de concentração e de clara opção geopolítica no âmbito federal, a Região Metropolitana de Salvador (RMS) já nasce de uma crise de configuração: desde sua criação, em 1973, ela é recortada do Recôncavo, sua região matriz, e passa a ser definida por um conjunto de municipios, cujas principais relações deveriam ser funcionais e decorrentes dos novos projetos industriais para eles implementados. Uma região vertical e corporativa se desenvolve a partir de então, 
ancorada num conjunto de pares de oposição: crescimento acelerado da produção paralelamente à elevação contínua das taxas de desemprego; municípios ricos e populações muito pobres; extrema concentração de renda e generalização da pobreza; produção industrial agressiva em ambientes naturais muito sensíveis; Salvador, cidade dormitório industrial e Salvador, centralidade absoluta de serviços; esgotamento do modelo e reforço - com variações - do mesmo modelo.

Fragmentado e contraditório: talvez assim possamos designar, na Bahia, o espaço metropolitano contemporâneo, produzido por esse processo e dele condicionante. Fragmentação na escala regional, na escala metropolitana, na escala urbana e na escala intra-urbana, com um sistema urbano operado por saltos, por descontinuidades, pelo aprofundamento das exclusões.

$O$ presente livro nos mostra contornos e entranhas dessa região, com seus dilemas econômicos, sociais, culturais, raciais, institucionais, espaciais. A cartografia e os indicadores trabalhados revelam recorrentemente imagens fortes, claras, inquietantes: a RMS do ano 2000 continua partida, segmentada, excludente. Logo, saber que Salvador "anda" não basta, nem nos dispensa de conhecer o "como anda", pois poucos são os indícios concretos aqui apresentados de transformação positiva da realidade dessa grande região urbana.

No entanto, as cidades, particularmente as metrópoles, por sua história, por sua complexidade e por suas contradições, geram espaços de esperança, onde as diferenças, a liberdade, os conflitos e o interesse comum trazem a possibilidade efetiva de construção de horizontes sociais alternativos. Não há por que duvidar disso. 



\section{A ECONOMIA DE SALVADOR E A FORMAČ̃̃ DE SUA REGIÃO METROPOLITANA}

Paulo Henrique de Almeida*

Este capítulo resume a evolução da economia de Salvador, de meados do século XX ao início dos anos 2000. Uma questão o guia: por que a economia dessa metrópole apresenta um ritmo de crescimento tão baixo na passagem do século, a ponto de convertê-la em recordista brasileira do desemprego? As respostas aqui ensaiadas se baseiam em dois pressupostos: primeiro, para compreender a evolução econômica recente da capital da Bahia é necessário resgatá-la de um passado mais remoto, de uma perspectiva de "longa duração"; segundo, é preciso ainda pensá-la em um contexto mais amplo, que vá além do seu arrière-pays, o Recôncavo Baiano e o estado da Bahia, de modo a enxergar os laços que sempre manteve com a economia mundial.

\section{BOOM E LIMITES DA CACAUICULTURA}

Até o final dos anos de 1940, a economia de Salvador, e de seu tradicional hinterland, o Recôncavo Baiano, permaneceu atrelada à evolução de alguns complexos estaduais exportadores de commodities minerais e agrícolas. A pauta baiana de exportação incluía cerca de uma dezena de itens, mas somente três produtos se destacavam: cacau, açúcar e fumo. A dependência em relação a essas três commodities definia um estreito horizonte de expansão para a economia da região, pois a Bahia, além de sofrer de modo intenso com as bruscas variações da demanda

* Professor do Mestrado em Economia da Universidade Federal da Bahia, Doutor em Economia pela Universidade de Paris X, Nanterre. 
e dos preços dos bens primários no mercado mundial, especializou-se em produtos cuja oferta aumentava rapidamente, com o aparecimento de novos concorrentes. Às flutuações e crises cíclicas, típicas dos mercados de matérias-primas, somou-se uma tendência secular à diminuição da fatia dos complexos baianos nos mercados nacionais e estrangeiros.

Essa particularidade dos complexos baianos de exportação marcou mais intensamente a evolução das atividades canavieiro-açucareira e fumageira no Recôncavo, que não conseguiram se modernizar e foram ultrapassadas pela produção de São Paulo (açúcar) e do sul do país (tabaco). Mas caracterizou, também, a evolução da oferta dos outros bens presentes na pauta: borracha vegetal, café, couros e peles, piaçava, ouro, manganês e outros minérios. Algumas dessas matérias-primas tiveram importância efêmera. Outras, tiveram uma presença mais constante na pauta, mas com valor pouco significativo e declinante. A única a se destacar foi o cacau, principal produto de exportação da Bahia até os anos 60.

As exportações de cacau passaram de $13 \%$, do total das exportações baianas em 1890, para mais de 40\%, no final da década de 1920. Durante esse mesmo intervalo, o cacau respondeu por cerca de $20 \%$ a $25 \%$ das receitas públicas estaduais (CPE, 1980, p. 77). Mas as dificuldades para a cacauicultura baiana começaram a surgir ainda nas primeiras décadas do século XX: com o aumento do consumo mundial de chocolate, os ingleses passaram a estimular a produção africana de cacau, o que acabou deslocando a cacauicultura baiana para uma posição secundária no mercado externo (Prado Jr., 1970, id., p. 248). É importante, de qualquer modo, não superestimar as dimensões da economia cacaueira e do volume de seu excedente. $\mathrm{Na}$ verdade, a massa de excedente criada pelo cacau na Bahia nunca alcançou o tamanho da produzida pelo café em São Paulo, ou pelo algodão e açúcar no Nordeste. Em 1929, no final do auge das exportações de cacau, as vendas desse produto no exterior representavam apenas $6 \%$ das exportações totais do país (CPE, 1980, p. 20).

Assim, a cacauicultura, diferentemente da lavoura do café em São Paulo, não pôde acelerar o crescimento urbano-industrial na Bahia. As dimensões da atividade cacaueira eram insuficientes para gerar uma das condições básicas dessa aceleração: a disponibilidade de uma "massa crítica" de excedente, concentrada sob a forma de capital-dinheiro num momento de boom, que pudesse ser transformada em capital industrial numa escala considerável. Além disso, a extrema concentração do excedente gerado pela cacauicultura - principal atividade econômica do estado, entre as décadas de 1910 e 1950 - limitou as possibilidades de expansão do mercado regional para produtos industriais e serviços.

0 próprio beneficiamento do cacau permaneceu quase sempre restrito à secagem das amêndoas em condições rudimentares, o que gerou possibilidades de investimento agroindustrial limitadas, até mesmo inferiores às existentes nos casos do tabaco e da atividade canavieiro-açucareira. Isso não excluiu o surgimento de um pequeno setor industrial de produção de derivados do cacau, concentrado em Salvador, 
setor que, no entanto, só conheceu alguma expansão a partir dos anos 40.

Além disso, é necessário lembrar que uma parcela não desprezível do excedente criado pela cacauicultura acabou sendo deslocada para outras regiões do país, especialmente para o Rio de Janeiro, atraída pelas melhores oportunidades de investimento em outras praças ou absorvida pelo comércio de outros centros. A região cacaueira - o eixo llhéus-Itabuna - deslocou seu abastecimento, em bens de consumo, da capital para o centro e sul do país, estabelecendo laços comerciais diretos com as cidades de Vitória, do Espírito Santo, Rio de Janeiro, Teófilo Otoni e outras cidades mineiras (ver Santos, 1954). ${ }^{1}$

Em suma, apesar da cacauicultura, não surgiu na economia baiana um novo front de acumulação capaz de garantir a expansão acelerada do conjunto da economia regional, levando-a a dar o salto de qualidade que caracterizou a evolução da economia cafeeira paulista. Concretamente: uma fronteira de acumulação capaz de criar as condições iniciais para o desenvolvimento de um processo de desenvolvimento centrado na expansão industrial (e na imigração estrangeira). A cacauicultura não pôde cumprir esse papel: ela permaneceu isolada no sul do estado, região que conheceu algum desenvolvimento, mas sem que, com isso, fosse alterado o quadro de crise do Recôncavo, isso é, da Bahia propriamente dita.

Nesse hinterland imediato de Salvador, e no mesmo período, a agricultura canavieira e fumageira de longa história colonial conheciam, em contraste com 0 relativo vigor da economia do cacau, um acelerado declínio.

Pressionado pela queda dos preços internacionais e atingido pela concorrência externa, o complexo canavieiro-açucareiro ainda manteve um certo peso na economia baiana até as primeiras décadas do século e, isso, graças à modernização de seu segmento industrial e à expansão do consumo nacional de açúcar. Ele respondeu, inicialmente, à crise com a introdução do trabalho assalariado e da máquina a vapor no seu segmento industrial, o que se fez com concentração do capital e aumento da escala de produção. Desde o final do século XIX, os antigos engenhos haviam começado a ceder lugar aos engenhos-centrais. Esse processo de modernização das unidades produtoras de açúcar continuou nas décadas seguintes com o aparecimento das usinas: cerca de duas dezenas de usinas absorviam a produção de cana-de-açúcar do Recôncavo no início dos anos de 1920 (CONDER, 1973, p. 46).

Mas, por volta de 1930, o quadro da agroindústria açucareira baiana já era de franca decadência. No que concerne às exportações, a situação do complexo baiano foi agravada pela modernização mais rápida da agroindústria açucareira de Pernambuco, que acabou por ocupar o pequeno espaço existente para o açúcar

${ }^{1}$ Reconhecer a importância dessa "fuga" de parte do excedente não implica aceitar a tese de que em sua maior parte ela tenha sido provocada pela política cambial dos anos de 1950, que teria prejudicado as exportações agrícolas do Nordeste em benefício da importação de bens de capital para as indústrias de São Paulo. Essa tese, de "confisco cambial", proposta por Mariani (1958) e retomada por vários historiadores da economia baiana, já foi suficientemente relativizada, sobretudo por Wilson Cano (1977, 1981). Cano enxerga aí uma tentativa de representantes das elites baianas de passar para o "imperialismo paulista" uma parte de suas próprias responsabilidades com relação ao atraso econômico da Bahia. 
nordestino no exterior. No que se refere ao mercado interno, a situação se complicou com a crise de 1929. Como lembrou Szmrcsányi (1979 e 1988), os empresários de São Paulo abandonaram parcialmente a cafeicultura a partir de 1930, diversificaram seus negócios e se interessaram inclusive pelo açúcar. Quando a produção açucareira paulista começou a crescer, as usinas baianas não puderam resistir à pressão dessa nova concorrência, baseada em uma tecnologia agronômica superior. Isso, basicamente, como resultado de uma persistente "dualidade técnica" - lavoura atrasada versus usinagem moderna - e dos baixos níveis de produtividade total dela derivados. 0 mercado para o açúcar baiano, no interior do país, ficou ainda mais restrito, continuando a existir apenas como resultado da proteção garantida pelo regime de cotas, nos marcos do antigo Instituto do Açúcar e do Álcool (IAA).

Quanto ao fumo, deve-se lembrar que o complexo fumageiro baiano era formado de três segmentos: uma fumicultura baseada no minifúndio, "armazéns" de beneficiamento vinculados a casas comerciais de exportação (com participação hegemônica de capital germânico) e algumas manufaturas de charutos e cigarrilhas. Ocupando dezenas de milhares de agricultores e operários manuais, esse conjunto de atividades, fundamental para a economia de Salvador, também conheceu seu auge entre o final do século XIX e as primeiras décadas do século XX. Com isso não se quer dizer que as exportações da folha tenham crescido aceleradamente no período: na verdade, elas permaneceram estabilizadas depois de 1900, ainda que no patamar, historicamente alto, de pouco mais de 25 mil toneladas por ano. $O$ que se quer afirmar é que, nesse período, consolidou-se o complexo do fumo na Bahia. 0 número de empresas baianas exportadoras de fumo passou de 6, em 1870, para 26, em 1890, e chegou a 40, em 1930 (Borba, 1975). O número de manufaturas de charutos também cresceu entre 1890 e 1930, ocorrendo ainda um intenso processo de concentração do capital nesse segmento. Abriu-se, assim, a possibilidade da transformação desse complexo "agro-manufatureiro-exportador" em uma moderna agroindústria do fumo, voltada para o mercado interno.

Entretanto, e mais uma vez, o salto qualitativo não se materializou e, basicamente, por quatro razões: $1^{\text {a }}$ ) a especialização da fumicultura baiana em tabaco escuro, destinado a charutos fortes, no momento em que a indústria mundial se deslocava para os fumos claros, matéria-prima para cigarros; $2^{\mathrm{a}}$ ) a concentração do crescimento urbano no Rio de Janeiro e em São Paulo, dificultando o acesso das empresas instaladas na Bahia aos principais mercados nacionais para artigos de fumo; $3^{\mathrm{a}}$ ) a vitória do truste anglo-americano do fumo (British American Tobacco), produtor de cigarros, na luta pelo mercado brasileiro, entre os primeiros anos do século XX e a década de 1930, truste que optou por desenvolver a fumicultura no sul do país, a partir da compra da Souza Cruz; e, $4^{\mathrm{a}}$ ) as derrotas alemãs nos dois conflitos mundiais, que reduziram a importância da colônia germânica em Salvador e a forte presença das empresas alemãs e de suas redes de relações internacionais na economia baiana.

A capital da Bahia se ressentiria da reduzida escala e do baixo dinamismo 
das atividades agropecuárias do estado até o final do século XX. Esse quadro só se modificou, parcialmente, com a expansão, a partir dos anos de 1980, da soja no Oeste baiano (Barreiras), da cafeicultura no Sudoeste (Vitória da Conquista) e também nos cerrados, da fruticultura irrigada no vale do São Francisco e de algumas outras lavouras mercantis, como o algodão no planalto de Guanambi. Parcialmente, de fato, porque, se essas novas atividades foram capazes de ampliar o mercado de consumo estadual, permitindo, inclusive, o desenvolvimento de uma nova classe média rural ou "rururbana", elas não foram mais suficientes para alavancar, a jusante ou a montante de suas cadeias, a produção regional de insumos e o desenvolvimento de novas atividades agroindustriais. Primeiro, e outra vez, por razões de escala. Mas também por timing: as oportunidades haviam sido perdidas e a localização dos principais pólos industriais do país já estava definida há mais de meio século; por conseguinte, uma fração considerável dos efeitos multiplicadores da nova agroindústria baiana não alcançou Salvador, mas serviu, principal e novamente, para irrigar a economia de outras regiões.

Numa perspectiva de longo prazo chega-se, assim, a uma primeira forte explicação para os elevados níveis de desemprego e pobreza na Salvador metropolitana da virada do século XX para o XXI. Faltaram, historicamente, à capital da Bahia, as redes econômicas e sociais que derivam de uma agropecuária capitalista stricto sensu e de uma agroindústria dinâmica, com participação crescente nos mercados nacional e/ ou internacional; faltou a conseqüente malha de cidades médias que se desenvolve a partir de uma agricultura diversificada, que opera para mercados extra-regionais; faltaram, enfim, os mercados derivados da formação de classes médias rurais e da generalização do trabalho assalariado no campo, que garantiram o vigor da economia industrial e terciária de cidades como Porto Alegre ou São Paulo desde meados do século XIX, ou de Belo Horizonte e Curitiba na segunda metade do século XX.

\section{A ESTAGNAÇÃO DE SALVADOR NOS ANOS 1920-1940}

Sem mercados no campo, em virtude da lenta implantação de relações capitalistas de produção e da extrema concentração da propriedade fundiária e da renda gerada por uma produção agropecuária estagnada tecnologicamente, a incipiente indústria baiana permaneceu, durante a primeira metade do século $X X$, sem poder contar, também, com a expansão dos mercados urbanos regionais.

Os poucos centros urbanos existentes na Bahia, até a primeira metade do século XX, encontravam, a exemplo de Salvador, nas atividades de comércio e administração pública, seus principais suportes econômicos. Boa parte da população economicamente ativa era formada por descendentes analfabetos de escravos. A maior parcela das ocupações era encontrada na prestação de serviços pessoais, no artesanato, na burocracia estatal, na construção civil e no pequeno comércio varejista. O movimento comercial era limitado, basicamente, ao fluxo de mercadorias entre Salvador e as cidades menores, por via marítima, concentrando-se no interior do 
Recôncavo. Não existindo meios de transporte adequados, o comércio entre as cidades de menor porte tinha pouca expressão. Comércio, construção civil pesada (portos e estradas), transporte, crédito e serviços públicos cresciam em função da expansão das atividades agroexportadoras estaduais. Como a expansão dessas atividades era débil, além de cíclica, as cidades baianas não atraíam novos investimentos, nem, por consequêencia, imigrantes em busca de trabalho. Assim, pouco cresceram no período.

Mesmo no caso de Salvador, a urbanização se deu de forma muito lenta entre fins do século XIX e primeiras décadas do século XX. A população da capital, que atingiu a marca dos 170 mil habitantes em 1890, cresceu vegetativamente em todo o período 1890-1920. Nesse último ano, a cidade alcançou a marca, já então modesta para os padrões do eixo Rio-São Paulo, dos 280 mil habitantes. Mais grave: suas taxas de expansão demográfica anual, que haviam se situado entre 1,6\% e $1,7 \%$, entre 1872 e 1920, despencaram para apenas $0,2 \%$, entre 1920 e 1940, do que resultou uma população praticamente estável, de 290 mil habitantes em 1940. ${ }^{2}$

Poder-se-ia insistir: mas o excedente gerado pelo cacau não levou, indiretamente, a qualquer aceleração da acumulação de capital e do grau de urbanização na Bahia? De fato, a apropriação de parte desse excedente, pelo Estado, abriu a possibilidade de maiores investimentos em setores como transporte e obras públicas. Não se pode negar a existência desses investimentos, mas deve ser levado em conta, como já se sublinhou, o volume reduzido das novas inversões. 0 tamanho absoluto do excedente produzido pela cacauicultura e pelas outras atividades de exportação na Bahia, estas ainda menos importantes que a atividade cacaueira, e 0 modo concentrador pelo qual esse excedente era gerado e apropriado, barraram a expansão de segmentos fundamentais da economia baiana.

Em Salvador, o bairro comercial foi reformado, a elite ocupou novas áreas residenciais e desenvolveram-se os serviços, inclusive com a expansão das linhas de bondes. Contudo, a indispensável modernização do porto atrasou-se e só foi realizada, finalmente, graças ao financiamento estrangeiro. A oferta de energia elétrica era limitada, sendo seu fornecimento um dos principais pontos de estrangulamento da economia baiana. Também não se podia falar numa verdadeira rede de rodovias no estado. $O$ caminhão, que começava a se firmar como importante meio de transporte, tinha alcance limitado. No interior ainda se convivia com as tropas de burros e os carros de boi. As estradas de ferro, é verdade, tiveram sua quilometragem duplicada entre 1890 e 1930, passando de $1.057 \mathrm{~km}$ para $2.669 \mathrm{~km}$. Mas esse crescimento não podia ser comparado à expansão da rede ferroviária no sul do país e foi, além disso, comandado por "companhias de segunda e terceira categorias" (CPE, 1980, p. 31; 118). Em resumo, como afirmou Vieira Lins, a capital se distanciava do seu interior, "[...] que passava a ser assistido comercialmente pelos estados vizinhos e Salvador se reduzia, cada vez mais, à condição de metrópole do Recôncavo" (Azevedo, T; Lins, V., 1969, p. 228).

${ }^{2}$ Sobre este ponto, ver Cano (1977) e Souza (1980). 
Embora a Bahia não tenha conhecido, até a segunda metade do século $X X$, um intenso processo de expansão maquinofatureira, acabou se implantando no estado uma indústria de alguma importância regional. Desde o final do século XIX a indústria baiana contava com estabelecimentos produtores de açúcar e outros alimentos, fumo beneficiado e charutos, cigarros, sabão, óleos, velas, fósforos, chapéus, tecidos, bebidas alcoólicas, embarcações, ferramentas e peças metálicas, além de outros produtos diversos.

Reconhecer a relativa importância dessa indústria não significa incorrer no erro de superestimar o parque industrial baiano anterior a 1950. Alguns autores exageram o peso dessa indústria, apontando uma suposta expansão "fabril" e "vigorosa", entre o final do século passado e os anos de 1920, e imaginando um falso "retrocesso" industrial após esse período. Tais autores não têm razão: em primeiro lugar, trabalhando exclusivamente com a categoria "estabelecimentos", confundem artesanato e manufatura com verdadeiras fábricas; em segundo, equiparando "crescimento industrial" a "industrialização", omitem o fato de que a indústria baiana tinha um reduzido grau de diversificação e articulação interna, e que se limitava, basicamente, ao processamento de matérias-primas regionais e à produção de alguns poucos bens de consumo corrente; finalmente, desconhecem o fato de que a indústria existente ainda não havia alcançado um tamanho mínimo a partir do qual se poderia falar, propriamente, de acumulação autônoma do capital industrial. ${ }^{3}$

Nos principais segmentos dessa indústria (usinas de açúcar, fábricas têxteis, manufaturas de charutos) eram estreitos os laços que uniam o capital industrial às grandes casas do comércio de exportação e importação. Na Bahia, entretanto, a transformação do capital comercial em capital de indústria, com a diversificação dos investimentos realizados pelas grandes casas comerciais, ocorreu numa escala bem menor que em outras regiões do país. A debilidade das atividades exportadoras baianas e o processo específico de desenvolvimento das relações capitalistas de produção na Bahia, com transição lenta e indireta para o assalariamento no campo, implicaram limitada mercantilização da economia estadual e barraram a intensificação daquela metamorfose. A debilidade das atividades de exportação limitou a expansão do mercado regional e restringiu o próprio crescimento do capital comercial, o que, por sua vez, reduziu o volume de excedente passível de transformação em capital de indústria. ${ }^{4}$

Deve-se considerar, ainda, que a inexistência de um sistema de crédito bancário desenvolvido, que pudesse potencializar a referida transformação, criou

${ }^{3} \mathrm{O}$ que não desmerece em nenhum momento a qualidade da pesquisa desses grandes historiadores. Trata-se, em todo caso, de um discurso muito presente nos anos 1950-1970, que vai da "decadência baiana", de Mariani (1958), à "dependência baiana", de Ritz (1972), passando pelo famoso "enigma baiano", de Pinto de Aguiar (1958), e pela "involução industrial da Bahia", de Tavares (1966).

${ }^{4} \mathrm{Na}$ Bahia, como em geral no Nordeste, a passagem do trabalho escravo para o trabalho assalariado pleno levará várias décadas, graças à manutenção de formas de parceria, como a meia na agricultura e a quarta na pecuária, somada à persistência do minifúndio, da agricultura de subsistência e de sistemas arcaicos de abastecimento, como o "barracão", que também bloqueavam a monetarização da economia rural. 
dificuldades adicionais para a ampliação do parque industrial instalado na Bahia. Não que o sistema bancário não tivesse se expandido desde o século XIX: ele realmente se expandiu, com a abertura de agências de bancos estrangeiros na praça de Salvador e com a consolidação de pelo menos dois bancos regionais (ver Azevedo e Lins, 1969; Oliveira, 1993). No entanto, o desenvolvimento desse sistema foi estrangulado pela hegemonia das grandes casas comerciais na oferta e na intermediação do crédito de custeio para a agropecuária, sem dúvida, o principal e quase exclusivo espaço para a valorização do capital de empréstimo na economia baiana do período. Financiamentos de longo prazo e baixa rentabilidade, indispensáveis para a expansão industrial, não estavam entre os principais interesses dos bancos na Bahia, preocupados, sobretudo, em ofertar crédito - ainda que, às vezes, indiretamente, através das casas de comércio - à agricultura de exportação.

As condições desfavoráveis que marcaram a gênese da indústria baiana foram responsáveis pela consolidação de uma estrutura industrial caracterizada, fundamentalmente, pela predominância de minúsculas empresas, mais próximas do artesanato e da manufatura que de verdadeiras unidades fabris. É verdade que a implantação da indústria têxtil e a modernização da atividade açucareira exigiram grandes concentrações iniciais de capital, assim como níveis tecnológicos equivalentes aos então dominantes no país e, mesmo, no mundo. Também é certo que, no ramo fumageiro, grandes firmas puderam surgir a partir da iniciativa de pequenos capitalistas - Suerdieck e Dannemann são os melhores exemplos. No entanto, esses ramos, que produziam para mercados externos e que se beneficiavam de vantagens locacionais significativas, foram exceções que apenas confirmaram a regra geral. Embora o número de estabelecimentos "industriais" tivesse crescido no período entre o final do século XIX e os anos 1930-40, a indústria localizada em Salvador e no seu entorno abstraídos os três setores destacados - manteve características atrasadas, quer no que diz respeito ao tamanho médio dos estabelecimentos, quer no que se refere ao padrão tecnológico predominante. A realidade é que, até os anos de 1940, existiam muito poucas fábricas na Bahia. A maioria dos estabelecimentos da indústria baiana era constituída por unidades de artesanato e manufaturas em sentido estrito, isso é, que "faziam à mão". Em 1930, como lembram Borba e Santos (1978), das 2.204 empresas "industriais" do estado "[...] apenas 61 tinham mais de 12 operários, 158 tinham de 7 a 12, 600 tinham de 1 a 6 e nada menos que $1.325(60,1 \%)$ tinham apenas um trabalhador [...]".

Pode-se resumir afirmando que a economia baiana conheceu, do final do século XIX aos anos 1930-1940, um período de lento crescimento, marcado pelo débil dinamismo ou pela instabilidade de suas atividades agroexportadoras, pela dominação quase absoluta do capital comercial sobre o conjunto das atividades econômicas regionais e, ainda, por baixas taxas de expansão urbana e industrial. ${ }^{5}$

\footnotetext{
${ }^{5}$ Pressionada no mercado nacional pela concorrência da indústria paulista, estrangulada no mercado regional pelo débil dinamismo das atividades agroexportadoras estaduais e pela reduzida penetração das relações capitalistas de produção no campo, a indústria baiana de bens não-duráveis conheceu
} 
Isso não significa dizer que a economia baiana tenha atravessado um período de generalizada "estagnação" ou "involução". A lentidão do desenvolvimento da economia estadual deve ser vista como um fato relativo: ela não deixou de crescer; apenas não acompanhou a vigorosa expansão da economia cafeeira e acabou por perder a posição privilegiada que detinha na economia brasileira, pelo menos até meados do século XIX. A perda dessa posição, visivel desde a consolidação da cafeicultura em São Paulo, acelerou-se com o desenvolvimento mais rápido das forças capitalistas de produção e com a concentração do crescimento industrial naquele estado.

No que diz respeito à indústria, a passagem da economia baiana para uma posição secundária no plano nacional tornou-se evidente já nas primeiras décadas do século XX. De acordo com os dados do Censo de 1920, a indústria baiana já era "insignificante" em relação ao Centro-Sul, como lembra Azevedo (1975, p. 35): sua participação no valor da produção nacional era, então, de 2,8\%. Ademais, ocupava apenas $5,7 \%$ do total dos operários do Brasil, com 3,5\% do valor total do capital, utilizando apenas $4,0 \%$ da força motriz instalada. Tais números, lembra o mesmo autor, "[...] vão se reduzir no Censo de 1940, quando a participação da produção cai para $1,8 \%$, a força de trabalho industrial baiana passa a ser $3,0 \%$ do total brasileiro, enquanto a participação no capital nacional e na força motriz instalada cai para 1,9\% e $2,3 \%$ respectivamente".

Ainda na perspectiva de longo prazo, chega-se, assim, a uma segunda causa histórica para o baixo dinamismo da economia de Salvador e para os seus conseqüentes níveis de desemprego e pobreza na virada do século XX para o XXI. Faltou a Salvador uma verdadeira base industrial, a exemplo daquela que pôde se desenvolver em capitais como São Paulo e Porto Alegre e, mesmo, em cidades de porte médio do interior dos estados brasileiros mais ricos. Uma base que fosse diversificada e complexa, reunindo empresas de diversos ramos e tamanhos, e operando com rendimentos crescentes, a partir de externalidades positivas geradas por sua própria expansão: mercado regional de mão-de-obra qualificada, difusão de conhecimento tácito, fortes redes de distribuição etc. Vale ressaltar que essa ausência teve desdobramentos político-sociais de grande significado econômico: de um lado, a preservação da hegemonia política de uma oligarquia agrária conservadora, de cultura patrimonialista; de outro, a inexistência de uma forte classe operária industrial que, organizada em sindicatos e partidos políticos, pudesse impor melhores condições de habitação, trabalho e remuneração na capital.

uma taxa média de crescimento anual de apenas $0,2 \%$, nas décadas de 1920 e 1930 . Embora outros setores da indústria baiana - bens intermediários, duráveis e de capital - tenham apresentado taxas de crescimento bem mais elevadas, em torno de $8,0 \%$ ao ano, esse fato teve pouco significado: tais setores praticamente nada representavam no contexto da indústria regional da época. Em 1941, os ramos têxteis, fumageiro e de produção de alimentos (inclusive açúcar), ainda concentravam quase $80 \%$ do valor da produção industrial no estado (Azevedo, 1975, p. 39). 


\section{A ECONOMIA DE SALVADOR ENTRE 1950 E 1980 - A NOVA INDÚSTRIA}

A situação econômica da Bahia e de Salvador começou a mudar entre os últimos anos da década de 1940 e o final dos anos de 1950. Algumas iniciativas estatais abriram caminho para rápidas transformações, entre elas a construção da usina hidroelétrica de Paulo Afonso, a implantação das atividades de extração e refino do petróleo no Recôncavo, a construção da ligação rodoviária Rio-Bahia (BR-116) e a criação do Banco do Nordeste do Brasil e da Superintendência do Desenvolvimento do Nordeste.

Paulo Afonso ampliou a oferta de energia elétrica para o consumo industrial no estado, eliminando um dos principais pontos de estrangulamento da economia regional. As obras da primeira usina do complexo hidrelétrico foram iniciadas em 1949, após a criação efetiva da CHESF - Companhia Hidroelétrica do São Francisco, em 1948, e a entrada em operação das primeiras turbinas ocorreu em 1954, assegurando-se, a partir de então, mediante sucessivas ampliações, 0 abastecimento de Recife e Salvador.

A BR-116 começou a ser construída em 1939 e foi concluída, mas não asfaltada, em 1949. Foi a primeira estrada brasileira de longo percurso e a primeira grande via terrestre de integração nacional, permitindo o rápido desenvolvimento do comércio interestadual e acelerando o processo de conexão entre a economia regional e o centro industrial do país. Essa conexão, é importante sublinhar, consolidou-se também em um outro sentido, na medida em que permitiu a transferência massiva de mão-de-obra excedente da Bahia para as cidades de São Paulo e Rio de Janeiro.

Com a entrada em operação do BNB, em 1954, e a criação da SUDENE, em 1959, expandiu-se a oferta de financiamentos públicos de baixo custo, amortizáveis em longo prazo, capazes de garantir novos investimentos industriais, a modernização das plantas já existentes e a implantação de infra-estrutura urbana (água potável, saneamento, energia, telecomunicações e transporte). Tais financiamentos se multiplicaram nos anos 60 e 70, com base em duas fontes de recursos: de um lado, o repasse de empréstimos externos, principalmente, do BID - Banco Interamericano de Desenvolvimento, e, de outro, os depósitos oriundos dos sistemas de incentivos fiscais (desde 1962, através do dispositivo 34/18, que permitia a dedução do Imposto de Renda de pessoas jurídicas para aplicação em projetos industriais nordestinos) e, a partir de 1974, via FINOR - Fundo de Investimentos do Nordeste (que, também por meio de deduções do $I R$, abriu maior espaço para empresas nordestinas no mercado nacional de capitais) (BNB, 2005). Esses novos sistemas de incentivos fiscais, centralizados pelo BNB e pela SUDENE, teriam uma importância vital no desenvolvimento econômico de Salvador e sua região periférica, na medida em que estas viriam a ser as principais beneficiárias dos recursos mobilizados para investimentos no Nordeste.

O mais importante dos eventos econômicos do período foi, todavia, a 
implantação da Petrobrás, que se traduziu na exploração do petróleo no Recôncavo, na construção do terminal marítimo de Madre de Deus e na implantação da refinaria Landulpho Alves em Mataripe (RLAM). Além de transformações imediatas na economia do Recôncavo (redefinição do uso de terras antes destinadas à agropecuária, crescimento de algumas cidades de pequeno porte, surgimento de uma importante malha rodoviária), os investimentos da empresa estatal provocaram um incremento considerável da renda gerada no estado. No ano de pico para as inversões (1959), os investimentos da Petrobrás na exploração e refino do petróleo foram equivalentes a 59,9\% do PIB industrial da Bahia e a 7,9\% do seu PIB total (CEPLAB, 1978, p. 14). Além disso, os investimentos diretos, somados aos investimentos nas atividades de suporte para a implantação e funcionamento da indústria petrolífera, permitiram a constituição de um mercado de força de trabalho especializada, passivel de recrutamento para as novas atividades implantadas na esteira da estatal (Azevedo, 1998).

Nas duas décadas seguintes à implantação da empresa, a economia do entorno de Salvador continuou transformando-se aceleradamente, sobretudo com a expansão de uma nova indústria centrada na petroquímica e na metalurgia. A RLAM estimulou, ainda no final dos anos de 1950, o investimento em fábricas de produtos químicos, que visavam ao aproveitamento das matérias-primas disponibilizadas pela refinaria. As inversões da Petrobrás também levaram ao desenvolvimento de algumas indústrias metal-mecânica, associadas ao fornecimento de equipamentos para a estatal. $\mathrm{O}$ grande salto de qualidade na evolução da indústria baiana dar-se-ia, entretanto, com os investimentos nas fábricas do Centro Industrial de Aratu (CIA) e do Complexo Petroquímico de Camaçari (COPEC).

O CIA, criado em 1967, viria a ser o mais destacado exemplo baiano de uma concepção de industrialização, baseada na apropriação, por policy makers brasileiros, de algumas teorias de desenvolvimento regional, em voga nos anos 50 . Essa concepção, já presente no documento fundador do planejamento baiano - 0 PLANDEB, Plano de Desenvolvimento da Bahia, de 1959 - estava assentada em versões vulgarizadas de três idéias-chave: o "distrito industrial", de Marshall (1900,1919), o "pólo" de "indústrias motrizes" ou "propulsoras" de Perroux $(1950,1955)$ e os "encadeamentos a jusante e a montante", de Hirschman (1958).

No caso do $\mathrm{ClA}$, e de inúmeras outras zonas ou distritos industriais criados artificialmente no Brasil e em outros países, os ricos modelos europeus estudados por Marshall, caracterizados pela auto-organização e sustentados numa lenta acumulação de capital social e conhecimento tácito, foram traduzidos em uma intervenção estatal que se resumiu, na prática, a somar incentivos fiscais à preparação de áreas (terraplenagem, ruas, pistas de acesso), onde se implantou infra-estrutura básica (abastecimento de água, energia elétrica, telecomunicações e saneamento) e se garantiu o fornecimento de alguns serviços essenciais (transporte, segurança). A partir desses investimentos, alguns terrenos foram oferecidos, para compra, arrendamento ou uso gratuito, às empresas porventura interessadas na implantação de fábricas. Esse tipo de ação, difundida internacionalmente, mostrou-se arriscada 
também na Bahia: de fato, se o uso intensivo dos incentivos fiscais e creditícios, que no CIA foram, basicamente, os do dispositivo 34/18, via SUDENE, e os do crédito relativo ao Imposto de Circulação de Mercadorias através do governo estadual, permitiram atrair pouco mais de uma centena de plantas, o Distrito assim criado se mostrou desconectado da economia local, pouco integrado setorialmente e, o que foi pior, efêmero.

Os dois primeiros problemas foram sublinhados, inicialmente, por autores como Azevedo (1975) e Canuto (1976), a partir das análises de Castro (1971) e Oliveira; Reichstul (1973). Mais recentemente, pesquisadores da indústria baiana, como Guerra e Teixeira (2000) e Menezes (2001), continuaram insistindo na "falta de identidade setorial clara" de investimentos subordinados à lógica de expansão da indústria do Centro-Sul do país e marcados pela concentração na produção de bens intermediários com base em tecnologias intensivas em capital. ${ }^{6} \mathrm{~A}$ efemeridade, por sua vez, seria confirmada entre a segunda metade dos anos 80 e a primeira dos de 1990. 0 esgotamento da industrialização, por substituição de importações com base no endividamento externo e interno, a crise fiscal e a virada neoliberal dos policy makers nacionais, levaram ao esvaziamento das políticas regionais de desenvolvimento e, antes de tudo, ao fechamento da torneira dos incentivos fiscais bancados nacionalmente. Isso liquidou com empresas que não tinham escala e fôlego financeiro para suportar as novas condições de concorrência. "No contexto de abertura comercial e desregulamentação econômica" que caracterizou o período seguinte, como afirma ainda Cavalcante (2004, p. 131), não houve mais espaço para uma política de atração de indústrias baseada em uma estratégia de "complementaridade com a economia da região Sudeste do país". O ClA se esvaziou, sendo caracterizado, no início dos anos 2000, pela imprensa baiana, como um "cemitério de empresas" ou, mais precisamente, nos termos de Spinola (2001, p. 42), como "uma sombra do grande empreendimento sonhado na década de 60 e que, segundo os seus idealizadores, iria transformar a face da Bahia, projetando-a como um estado moderno, industrializado e, conseqüentemente, desenvolvido".

No caso da RLAM e da sua extensão a jusante, o COPEC, implantado entre 1972 e 1978, o modelo de intervenção estatal foi inspirado diretamente nos conceitos de Perroux e Hirschman, como os textos de Rômulo de Almeida deixam explícitos (ver, por exemplo, Almeida, 1986). Para Perroux, o desenvolvimento não ocorreria de forma uniforme numa economia, mas tenderia a se concentrar num número

\footnotetext{
${ }^{6}$ Como lembra Cavalcante (2004), ainda que o CIA seja freqüentemente associado à indústria de bens de consumo final, ele abrigou, na realidade, uma proporção considerável de indústrias produtoras de bens intermediários, particularmente na siderurgia, metalurgia e mecânica. Não foi por acaso que a Usina Siderúrgica da Bahia, do grupo Gerdau, foi a primeira grande indústria

${ }^{7} \mathrm{Na}$ verdade, o CIA conheceria alguma recuperação a partir de 1995, com novas empresas ocupando antigas plantas desativadas. Essa "revitalização" se daria, é importante frisar, em momento completamente distinto: 0 da migração de indústrias footloose, em busca de incentivos fiscais e salários baixos, nos anos da "guerra fiscal" interestadual, da virada do séculos XX para o XXI. Voltar-se-á a esse ponto mais adiante.
} 
limitado de núcleos ou focos industriais. Ele era visto como a mudança estrutural provocada no espaço econômico pela expansão desses núcleos de indústrias dinâmicas. Os pólos de crescimento industrial iniciariam o processo que seria, em seguida, difundido ao resto da economia por efeitos multiplicadores e de aglomeração sobre 0 investimento, a renda e o emprego, incluindo a multiplicação de pequenas empresas. A teoria de Perroux se completava, assim, com a idéia de encadeamentos para frente e para trás de Hirschman (1958). Diga-se, ainda, que as indústrias "motrizes" eram associadas à indústria pesada (siderurgia, metal-mecânica, química), evidenciando as relações entre a teoria dos "pólos de crescimento" e o modelo soviético de desenvolvimento adotado a partir dos anos de 1930 (Almeida, 2002c).

Com o COPEC, esse tipo de concepção de desenvolvimento daria suporte a um novo e gigantesco pacote de investimentos na periferia de Salvador, que, no bojo dos Planos Nacionais de Desenvolvimento (1972-1979), seria bancado, sobretudo, pelo Governo Federal. Como nota Guerra (2001), entre outros autores, três razões explicariam esse novo ciclo de investimento industrial. Em primeiro lugar, o fato de que a Bahia se transformara no principal estado produtor de petróleo do país e abrigava uma grande refinaria, passível de ampliação; em segundo, e como conseqüência, porque a Bahia era a localização ideal para um novo pólo petroquímico, capaz de atender à crescente demanda de insumos básicos da indústria brasileira concentrada em São Paulo; e, finalmente, porque o governo central ainda defendia, na época, uma política de integração nacional baseada, em tese, no objetivo de diminuição dos desequilibrios regionais. Essa política conduziria, de forma planejada, isso é, sob a orientação da SUDENE e dos Planos Nacionais de Desenvolvimento, a grandes inversões de capital público, estrangeiro e privado, também no entorno de Salvador.

Operando em grande escala, e com tecnologia de ponta, as novas fábricas do Pólo Petroquímico, implantadas entre os anos de 1970 e 1980, alteraram completamente o perfil da indústria baiana, no que foram ajudadas por outros grandes empreendimentos isolados, como aqueles centrados na siderurgia (SIBRA, FERBASA e USIBA) e na mineração-metalurgia do cobre (Caraíba Metais, inaugurada em 1984). $O$ que seria mais importante para a economia estadual é que, diferentemente das fábricas de bens finais do CIA, essas grandes empresas teriam consideráveis custos potenciais de saída, o que asseguraria a perenidade das suas plantas.

Em 1981, os investimentos no Pólo Petroquímico de Camaçari somavam algo em torno de US\$3,7 bilhões. No mesmo ano, o PIB da Bahia poderia ser estimado em, mais ou menos, US\$ 12 bilhões, ou 4,4\% de um PIB brasileiro da ordem de US\$ 267,5 bilhões. Assim, os investimentos do Pólo representavam o equivalente a 30\% do PIB estadual, uma proporção quatro vezes superior à registrada para a implantação da Petrobrás, pouco mais de vinte anos antes (Almeida, 1999). Tratava-se, portanto, de um evento de inegável importância para a dinâmica econômica do estado: 0 segundo de maior significado, na história da Bahia do século XX, e que só não pode ser considerado como o mais relevante, porque foi uma conseqüência quase direta da RLAM. 
Mudando o perfil da indústria regional, os investimentos na RLAM, no CIA e no COPEC, modificaram também a macroestrutura da economia baiana e causaram impacto intenso na economia de Salvador e do seu hinterland imediato. A participação da indústria no PIB estadual saltou de 12,0\%, em 1960, para 31,6\%, em 1980, e 38,1\%, em 1990 (Menezes, 2001, p.-50). O investimento industrial e a entrada em operação das fábricas do Pólo Petroquímico e de outras grandes unidades aceleraram a expansão do PIB baiano, que cresceu a taxas superiores às verificadas para 0 Brasil e Nordeste, entre meados da década de 70 e a primeira metade da década de 1980. A expansão da nova indústria teve importantes conseqüências, também, para a tributação estadual, com o ICM industrial passando de $30 \%$, do total desse imposto, para $55 \%$, no mesmo período. De um ponto de vista muito estrito, levando-se em conta apenas o produto e a estrutura setorial da sua economia, poder-se-ia dizer que a economia baiana, e principalmente a de Salvador e sua periferia, havia se "industrializado".

Contudo, esse não era o quadro real a partir do ângulo da ocupação e do emprego. A opção por uma indústria de bens intermediários, centrada em grandes plantas automatizadas de produção contínua, resultou em limitada criação de empregos diretos. Toda a nova indústria baiana havia gerado, ao final dos anos de 1980, cerca de 50 mil novos postos de trabalho, distribuídos quase meio a meio entre CIA e COPEC. Se isso significava cerca de metade da força de trabalho formal da indústria de transformação da Bahia - 94 mil postos em 1991, segundo a SEI (2002, p. 36) - continuava sendo uma quantidade pouco expressiva em face da demanda crescente por empregos que resultava da retomada da expansão urbana no estado. No Pólo Petroquímico, no início dos anos 90, US\$ 8 bilhões de investimento significavam 24 mil trabalhadores empregados diretamente. Vale dizer: 3 postos para cada milhão de dólares investido (Guerra, 2001, p. 15).

Não haveria, ademais, a compensação, sempre alardeada pelos policy makers baianos, da multiplicação de empregos industriais indiretos, uma vez que não ocorreram os "encadeamentos a jusante e a montante", previstos pela teoria adaptada de Perroux e Hirschman. Como sublinharam Spinola e vários outros economistas baianos, "o complexo petroquímico não produziu os efeitos multiplicadores (de polarização) esperados e que responderiam pelo desenvolvimento de um parque de indústrias de transformação, produtoras de bens finais, a jusante das suas centrais. Por outro lado, reduziu a capacidade de financiamentos de vários segmentos industriais alternativos, ao monopolizar a captação dos escassos recursos regionais para 0 financiamento da indústria" (2001, p. 36).

Houve, certamente, importantes efeitos induzidos sobre a construção civil e a produção de serviços, especialmente em Salvador e nos municípios em que se implantaram as novas fábricas, como será visto em outra seção. Quanto à limitada geração de empregos diretos industriais, isso revelava, todavia, apenas uma parte da questão. Uma análise mais fina da "industrialização" baiana mostraria uma estrutura industrial hiperconcentrada na química e na petroquímica, desde os anos 60 . A 
Petrobrás, e algumas poucas outras empresas do ramo, responderam por cerca de $30 \%$ do valor gerado pela indústria da Bahia até a implantação do Pólo: a partir daí, essa proporção saltou para mais de 50\% (ver Almeida; Damasceno, 2005b).

Avena (1983) definiu essa composição setorial como a de um "estado monoindustrial". Na realidade, a situação era mais inquietante, porque, à concentração em um ramo, se somavam as centralizações espacial e empresarial. Menezes (2001, p. 50) descreveu a realidade industrial baiana mais precisamente, ao falar de "tríplice concentração" na nova indústria e, por conseguinte, na nova economia da Bahia: em primeiro lugar, a convergência setorial, citada por Avena, com o gênero química respondendo por cerca de metade do valor de transformação industrial, ou seja, por $15 \%$ a $20 \%$ do PIB baiano; em segundo, a centralização empresarial, dado o caráter capital-intensivo da produção de bens intermediários, seu reduzido grau de relações intersetoriais e a presença pouco expressiva de empresas de médio ou pequeno porte. Do ponto de vista do capital, isso se traduziu em uma indústria estruturada em cerca de cinco dezenas de grandes empresas que, por sua vez, eram hegemonizadas por meia dúzia de grandes grupos empresariais associados aos governos federal e estadual; 8 e, em terceiro lugar, a concentração espacial, haja vista que as novas fábricas se instalaram na Região Metropolitana de Salvador (RMS, criada em 1973), ou em sua área de influência mais imediata, o município de Feira de Santana, onde outro "distrito industrial" foi implantado (o Centro Industrial de Subaé, também em 73). ${ }^{9}$

0 presente texto já chamou a atenção para o fato de que a ausência de uma base industrial diversificada e complexa, reunindo empresas de diversos ramos e tamanhos e operando com externalidades positivas geradas por sua própria expansão, explica, em grande parte, a relativa estagnação econômica de Salvador nos anos 1990-2000 e, por conseguinte, seus recordes de desemprego. Como se viu, a "industrialização", dos anos 1950-1980, apesar dos efeitos multiplicadores dos seus investimentos, não criou essa base. É importante sublinhar que isso não se deveu exclusivamente ao caráter capital-intensivo da nova indústria, caso se entenda, por isso, de um modo simplista, uma elevada relação técnica capital/trabalho. É preciso lembrar que a hiperconcentração setorial e da propriedade do capital, nessa indústria, reduziu também seus efeitos indiretos e induzidos. Primeiro, porque sua natureza de "quase enclave" implicou "vazamento" extra-regional da sua própria demanda de insumos; segundo, porque a concentração dos rendimentos do capital reforçou a concentração da renda do trabalho implícita na limitada geração de empregos diretos, com postos inicialmente bem remunerados, mas acessíveis apenas a uma minoria de trabalhadores qualificados; e, terceiro, porque implicou "fugas" e "vazamentos" extra-regionais do excedente, na medida em que os grandes grupos econômicos

\footnotetext{
${ }^{8}$ A retomada da centralização do capital no COPEC, nos anos 2000 , fez da indústria química na Bahia um ramo praticamente subordinado a apenas duas grandes empresas - a Petrobrás e a Braskem, esta última controlada por dois grupos familiares baianos, o Odebrecht e o Mariani.

${ }^{9} \mathrm{O}$ significado da criação da RMS será discutido mais adiante.
} 
envolvidos usaram seus lucros locais para impulsionar seus investimentos em outros estados e países. Todos esses elementos ficaram mais evidentes nos anos entre 1990-2000, quando a ampliação da indústria petroquímica regional (expansão da RLAM e do COPEC) se fez em paralelo à redução do já limitado emprego direto, do uso intensivo do outsourcing, da reconcentração do capital e de seu controle e da mudança das sedes de empresas locais para o Sudeste.

Diga-se, ainda, que tais efeitos multiplicadores só não foram menores na medida em que a tributação sobre a nova indústria incrementou os gastos públicos estaduais com custeio e investimento. Coube, em princípio, ao governo estadual, através desses novos recursos ou do endividamento que eles permitiram, ampliar os efeitos indiretos e induzidos da nova indústria, não apenas na RMS, mas, também, em outras regiões do estado. $O$ problema é que esse processo também foi limitado pelo fato de 0 executivo estadual ter de bancar o grosso dos incentivos fiscais no período seguinte, marcado não apenas pelo colapso dos antigos mecanismos nacionais de financiamento (FINOR, SFH etc.), mas, sobretudo, pela omissão federal em relação aos programas regionais de industrialização.

\section{A ECONOMIA DE SALVADOR ENTRE 1950 E 1980 - IMPACTO LIMITADO DA NOVA AGRICULTURA ESTADUAL}

Em contraste com a nova indústria, a produção agrícola baiana cresceu lentamente após 1950, compensando, parcialmente, a queda da fertilidade natural dos solos, secularmente utilizados, com a expansão mais acelerada da área cultivada. A fronteira agrícola foi ampliada, estendendo-se em direção às regiões do vale do São Francisco, Extremo-Sul e Oeste do estado. É fato ainda que, na década de 1970, acelerou-se a transformação das relações de produção no campo, com a expansão da força de trabalho assalariada e volante, residente na periferia de cidades do interior - os "bóias-frias". Mas a modernização da produção ocorreu vagarosamente na maior parte das lavouras e, esse atraso tecnológico, só seria revertido a partir da década de 1980, com a expansão da sojicultura mecanizada nos cerrados da região de Barreiras, no Além-São Francisco, da fruticultura irrigada (melão, manga, uvas) no norte do vale do mesmo rio e da produção de celulose no sul do estado.

Entre 1950 e 1980, os principais produtos agrícolas exportados pela Bahia foram cacau (amêndoas, manteiga e torta), sisal e algodão (fibras), mamona (óleo) e fumo. Foi somente por volta de 1985 que a pauta de exportações agrícolas começou a se expandir, com o café, a soja e algumas frutas (mamão e laranja). Os principais alimentos cultivados foram mandioca, feijão, milho e cana-de-açúcar. No setor pecuário, destacou-se somente a criação de gado bovino para corte e, apenas como atividade subsidiária, para leite.

A Bahia continuou concentrando cerca de $90 \%$ da produção brasileira de cacau, destinando-o, principalmente, à exportação (idem, p.-138). Em 1962, o governo 
federal criou a CEPLAC - Comissão Executiva do Plano de Recuperação EconômicoRural da Lavoura Cacaueira, órgão de pesquisa, desenvolvimento e financiamento da produção, que introduziu, em vinte anos, novas espécies, de maior produtividade, forneceu fertilizantes e defensivos e apoiou a renovação dos cacauais antigos, conseguindo, através dessas medidas, elevar a produtividade por hectare na cacauicultura baiana. A produção voltou a crescer a partir da segunda metade da década de 1960, depois de ter permanecido estagnada entre o imediato pós-guerra e 1965. A cacauicultura baiana, entretanto, não recuperou jamais a posição privilegiada que detinha no mercado internacional até os anos de 1930. Na segunda metade dos anos 80 , após vários anos de boom, puxado por uma extraordinária alta dos preços internacionais, seria quase dizimada por uma praga oriunda da Amazônia, a vassourade-bruxa, provocada por um fungo, o Crinipellis perniciosa.

A produção estadual de cana-de-açúcar, ainda concentrada no Recôncavo, cresceu lentamente no pós-guerra. Foram necessários cerca de 20 anos (1950-1970) para que dobrasse. Áreas tradicionalmente produtoras do Recôncavo foram abandonadas, em razão da extração do petróleo e da implantação das novas indústrias, ou como conseqüência da fragmentada estrutura fundiária regional, que retardou a mecanização da lavoura ao exigir prévia concentração da propriedade da terra. A expansão da área cultivada total, bastante apreciável entre o início dos anos 60 e a primeira metade da década de 1970, ocorreu graças à difusão da cana em outras regiões do estado, que não objetivava, necessariamente, o crescimento da produção usineira de álcool ou açúcar, mas a elaboração artesanal ou semi-artesanal de aguardente, rapadura e forragem para o rebanho bovino. A produtividade média por hectare, que já era baixa, continuou caindo, e isso apesar do uso mais intenso de fertilizantes e defensivos nas poucas fazendas controladas por usinas. Praticamente até meados dos anos 70, não havia ocorrido introdução de novas variedades mais rentáveis, nem progresso técnico considerável nas atividades de plantio e colheita (idem, p. 143).

O número de usinas de açúcar decresceu consideravelmente. Das 20 usinas em funcionamento em 1920, no Recôncavo, restavam 10, em 1965, e apenas 5, no início da década de 70 (CONDER, 1973, p. 81). E só duas sobreviveram até a virada do século. A Bahia, um dos maiores centros açucareiros do mundo durante o período colonial, tornou-se importadora de açúcar refinado. Alguns poucos projetos canavieiroaçucareiros, desenvolvidos no estado a partir dos anos de 1970, optaram pelas regiões de fronteira no vale do São Francisco. Mais grave: a produção de álcool-combustível não se viabilizou como alternativa real para a recuperação da atividade, pois as novas usinas de álcool-cana se concentraram em outras regiões do país, dotadas de uma lavoura canavieira mais avançada tecnicamente e próxima dos principais mercados para o produto.

Outras atividades agropecuárias floresceram na Bahia entre 1960 e 1980, sendo que algumas delas foram, inicialmente, consideradas muito promissoras. Todavia, após algum crescimento, perderam quase todo o dinamismo inicial, exceção 
feita à cafeicultura, beneficiada pela política federal de descentralização dos cafezais e protegida pelo crédito subsidiado. Na região de Guanambi, o algodão sofreu com a praga do "bicudo" e a instabilidade de preços. No Recôncavo, a citricultura e a avicultura foram esmagadas pela concorrência nordestina (laranja) ou paulista e mineira (laranja e aves). Nas áreas de horticultura (principalmente tomate e cebola), o grande entrave foi o lento crescimento da indispensável irrigação e do sistema estadual de comercialização e crédito. A Bahia, e Salvador particularmente, continuaram importando de outras regiões do país uma parcela relevante dos alimentos consumidos, fato que as estiagens, isoladamente, não podiam explicar.

Como a utilização de matérias-primas regionais foi limitada, basicamente, ao aproveitamento de parte das reservas minerais do estado, especialmente o petróleo, a nova indústria estabeleceu conexões pontuais com a agropecuária baiana. É verdade que o processamento da produção agropecuária regional avançou entre 1950 e 1980, pois surgiram novas empresas agroindustriais exportadoras, voltadas para 0 processamento do cacau, de óleos vegetais (dendê e mamona), celulose e papel, fibra de sisal e frutas (sucos e concentrados). Além disso, modernizou-se a produção de alimentos destinados aos mercados locais, com a implantação de matadouros industriais e frigoríficos, granjas modernas e fábricas de leite pasteurizado e em pó. Mas o processamento agroindustrial continuou sendo realizado de forma limitada, esbarrando sempre nos baixos níveis de produtividade e de volume de produção alcançados pela produção baiana de matérias-primas agrícolas, pouco capitalizada e sujeita, ciclicamente, aos efeitos das secas.

É necessário lembrar, ainda, que os focos e surtos de desenvolvimento agroindustrial se desenvolveram em regiões do estado cada vez mais distantes de Salvador. No hinterland metropolitano, o quadro, no período, foi de rápido esvaziamento da economia rural, e isso apesar de uma ou outra atividade agropecuária ter se desenvolvido pontual e temporariamente.

No Litoral Norte da capital, uma região marcada pela concentração fundiária, a decadência da produção açucareira levou a tentativas efêmeras de exploração da citricultura para suco, do coco e da madeira (primeiro para carvão vegetal e, depois, para celulose). Mas nenhuma dessas atividades tem relevância econômica, no início deste século XXI, voltando-se essa microrregião para uma relativamente bem sucedida combinação de indústria, serviços e veraneio (Camaçari) e de veraneio e turismo em destinos como Praia do Forte e Sauípe, no município de Mata de São João, beneficiados pela implantação de uma rodovia litorânea unindo Salvador à fronteira de Sergipe - a Estrada do Coco, aberta na metade dos anos 70, e sua extensão, a Linha Verde, ou BA-099, inaugurada em 1993.

Nas microrregiões do Paraguaçu (Feira de Santana), nos tabuleiros do Recôncavo e no Recôncavo Sul, a evolução da agricultura foi definida pelo declínio continuado dos complexos da cana-de-açúcar, baseado na grande propriedade, e do fumo, assentado no minifúndio, cujos eventos símbolos foram o fechamento de tradicionais usinas e manufaturas de charutos. Houve ensaios localizados de 
substituição dessas lavouras, com maior ou menor sucesso, como nos casos da exploração do dendê (Cachoeira), da celulose do bambu (Santo Amaro), da citricultura (Cruz das Almas) e da avicultura (Conceição de Feira). No entanto, a única atividade rural, praticada em larga escala, que sustentou um dinamismo moderado no período foi a pecuária bovina de corte, centrada em Feira de Santana e voltada para 0 abastecimento de Salvador.

Nessas três últimas microrregiões, isso é, no tradicional arrière-pays de Salvador, a transição do século XX para o XXI seria marcada, assim, pelo esvaziamento do campo e pela aposta em combinações restritas de investimentos industriais e atividades de serviços. $\mathrm{Na}$ indústria de transformação, vale a pena lembrar a implantação do já citado distrito de Feira de Santana, o Centro Industrial de Subaé, extensão do CIA, e, no período seguinte (entre os anos de 1990-2000), de algumas fábricas de calçados dispersas em pelo menos cinco municípios do Recôncavo. No caso dos serviços, é necessário notar a permanência do tradicional pequeno centro de varejo de Santo Antônio de Jesus, a expansão do ensino superior em Feira de Santana e outras cidades, com uma universidade estadual (UEFS), campi da UNEB e faculdades privadas e o crescimento dos serviços de saúde (em Feira). Além disso, desde 0 início dos anos 80, acreditou-se no estímulo ao turismo (Cachoeira e vários outros municípios), ainda que isso tenha mostrado uma performance sempre aquém da esperada e bem distante do movimento alcançado pelos destinos turísticos da RMS e do Litoral Norte.

Feitas todas essas ressalvas, é possível admitir que o aparecimento, na Bahia, de uma nova agroindústria, ainda que muito dispersa e também fortemente subsidiada, não deixou de repercutir positivamente sobre a economia de Salvador. De fato, as exportações agroindustriais ajudaram a sustentar o movimento do porto da capital e das atividades de serviços relacionadas ao comércio de exportação. Além da sustentação da atividade de exportação na capital, é importante ressaltar que o comércio de Salvador absorveu parte da demanda indireta e induzida por esses núcleos agroindustriais, o que também foi facilitado pela expansão e asfaltamento da rede rodoviária estadual, notadamente com a construção das BRs 101 e 242 - a primeira acompanhando o litoral e religando o estado ao Centro-Sul e ao Nordeste do país e, a segunda, unindo Salvador à Chapada Diamantina, aos cerrados do Além São Francisco e à Brasília. No entanto, esses efeitos foram limitados pelo caráter quase sempre pontual dos novos empreendimentos agroindustriais.

A opção por uma indústria de processo contínuo, automatizado, como a petroquímica, extremamente concentrada, não apenas do ponto de vista espacial, mas também no que diz respeito à propriedade do capital e à geração de renda, combinou com o relativo atraso, quase conseqüente, haja vista a escassez de recursos, da transformação agroindustrial do campo baiano. A Bahia, que não conseguiu construir uma agropecuária capitalista moderna na primeira metade do século $X X$, também não o fez nas três décadas que se seguiram ao pós-guerra. Na medida em que a agroindústria foi a principal atividade industrial criadora de empregos, no final do 
século XX, esse atraso cobrou seu preço em termos de êxodo rural e taxas elevadas de desemprego rural e urbano.

Vale a pena lembrar, ainda, que o declínio das duas principais lavouras de exportação do hinterland de Salvador não levou ao esperado desenvolvimento de um verdadeiro "cinturão verde", que melhorasse as condições de abastecimento da cidade e, ao mesmo tempo, permitisse o fortalecimento de uma nova classe média rural. As causas foram várias, a começar pela permanência de uma estrutura agrária polarizada entre a grande propriedade e o minifúndio. Além disso, corroboraram a falta de políticas governamentais consistentes e permanentes de financiamento e apoio tecnológico, as prioridades dadas ao uso do solo e da água (industrialização e abastecimento urbano), o incremento do preço da terra, a ausência de tradição cultural, tanto para a produção quanto para o consumo de hortícolas e, last but not least, a opção pela construção de um sistema público de abastecimento alimentar (Cesta do Povo, 1979; Empresa Baiana de Alimentos, 1980), fundado em uma estratégia de compras nacionais, exceção feita da farinha de mandioca adquirida localmente (ver, por exemplo, Maluf, 1999).

\section{A ECONOMIA DE SALVADOR ENTRE 1950 E 1980 - URBANIZAÇÃO CONCENTRADA E EXPANSÃO DOS NOVOS SERVIÇOS}

Acompanhando a implantação da nova indústria, a urbanização na Bahia ganhou novo ritmo após 1950. Essa aceleração do crescimento urbano, um processo concentrado em Salvador e seu entorno, se deu simultaneamente ao desenvolvimento de um "terciário moderno", para adotar a terminologia da época. A visão convencional descreve essa retomada da expansão urbana, e o conseqüente desenvolvimento dos serviços na capital, como resultado exclusivo da "industrialização", que se traduz numa determinada representação do funcionamento da economia regional, dominante desde os anos de 1960 e, ainda hoje, entre técnicos e policy makers baianos, a saber: o modelo de "base exportadora". Segundo essa representação, a grande indústria, sempre dinâmica porque voltada para a exportação, leva a reboque um "terciário" de crescimento derivado e sempre dependente da demanda local.

Os efeitos multiplicadores dos investimentos industriais no CIA e no COPEC foram mais que significativos, como se viu, e não podem ser negados. Contudo, para explicar o ritmo da urbanização e 0 avanço da terciarização na RMS deve-se levar em conta, além dos novos investimentos industriais, as transferências federais e os investimentos estatais e privados em outros segmentos da economia baiana, bem como as dinâmicas próprias, autônomas, de várias atividades dos novos serviços, algumas das quais - o melhor exemplo é o turismo - desde sempre voltadas também para o mercado extra-regional.

Na segunda metade do século XX, a Bahia permaneceu um dos estados menos urbanizados do país - tinha, em 1980, segundo os elásticos critérios do IBGE, 
um grau de urbanização ainda muito inferior à média do Brasil, com $49,25 \%$ da sua população residindo em cidades, enquanto $67,57 \%$ da população brasileira já se encontrava nessa situação (IBGE, 1983). Esse fato refletia, de um lado, a peculiar estrutura agrária e agrícola da Bahia, com forte presença da pequena propriedade e lento progresso da produtividade, e, de outro, a inexistência de uma rede de cidades médias no estado, dado o baixo dinamismo das atividades econômicas em boa parte de suas microrregiões. Esse baixo dinamismo desviou parte do fluxo migratório oriundo do campo baiano para outros pólos do país, notadamente São Paulo, reduzindo as taxas de crescimento das cidades de porte intermediário na Bahia (Borges, 1993). 0 atraso da urbanização no interior não impediu, contudo, o avanço da "metropolização" de Salvador nas décadas de 1960 e 1970, um fenômeno, então, comum a várias das capitais brasileiras.

A população da Região Metropolitana de Salvador atingiu a marca dos 1,8 milhão de habitantes, em 1980, dos quais quase 1,5 milhão na capital. No resto do estado existiam, no mesmo ano, apenas oito centros urbanos com população superior a 60 mil habitantes e, desses, só três com mais de 100 mil (Almeida; Damasceno, 2005b). Essa situação se confirmou nos anos de 1980 e 1990. Das 10 cidades do interior do estado com população superior a 100 mil habitantes, em 2000, duas Feira de Santana e Vitória da Conquista - cresceram a taxas semelhantes à verificada na capital na última década do século XX e apenas quatro se expandiram mais rapidamente - Barreiras, Camaçari, Lauro de Freitas e Juazeiro. Mas, desse conjunto de seis cidades médias que apresentaram algum dinamismo demográfico, duas delas, Camaçari e Lauro de Freitas, pertenciam a RMS e uma, Feira de Santana, a segunda cidade do estado, com cerca de 430 mil habitantes, era quase satélite de Salvador, sobretudo no que diz respeito à dependência da oferta de serviços superiores: serviços empresariais, ensino de pós-graduação, transporte aéreo etc. Além disso, é necessário frisar que a terceira cidade baiana em termos demográficos, Vitória da Conquista, tinha, em 2000, apenas 225 mil habitantes. Em síntese, num estado que praticamente não contava com aglomerações urbanas de porte médio, a capital, que havia crescido a taxas anuais de $3 \%$ a $5 \%$, entre os anos de 1950-1990, começaria o século XXI na condição de metrópole absoluta.

A RMS, que alcançaria o patamar de pouco mais de 3,0 milhões de habitantes em 2000, 80\% dos quais residindo na capital, constituiu-se num dos maiores mercados urbanos do país. Algumas razões para isso serão listadas a seguir; parte delas guarda relação longínqua com os efeitos indiretos ou induzidos pela nova indústria.

Salvador era a sede política e administrativa do estado, abrigando, além disso, instituições do governo federal e uma grande prefeitura, logo, um número considerável de funcionários públicos - cerca de $10 \%$ da população ocupada da cidade no final dos anos de 1980 (8,1\% apenas na administração pública, segurança e defesa) (ver Almeida; Damasceno, 2005b). O desequilíbrio da malha urbana do estado não deixaria de reforçar esse efeito "capital" sobre a economia soteropolitana, que se traduziria, 
de saída, na presença de uma importante classe média empregada, integral ou parcialmente, pelo Estado.

Apesar da pobreza da maioria de sua população, e de uma elevada concentração de renda, mesmo para os altos padrões nacionais, o tamanho de Salvador permitiu, por si só, o desenvolvimento de uma pequena indústria urbana (alimentos, materiais de construção, construção residencial, mobiliário, gráficas) e assegurou a expansão de serviços pessoais, atraindo, inclusive, grupos econômicos não-industriais já instalados no eixo Rio-São Paulo. Esses grupos avançaram sobre setores até então controlados pelo capital de origem regional, como comércio varejista, serviços financeiros e entretenimento, impulsionando sua já iniciada modernização. Destaque-se, nesse movimento, a rápida transformação do varejo, impulsionada pela concorrência e materializada na expansão das lojas de departamento, supermercados e shopping centers, entre os anos de 1960 e 1970. Ainda que parte desse processo deva ser associada aos efeitos multiplicadores do CIA e do COPEC, é preciso reconhecer que se tratava de inovações organizacionais difundidas nos EUA a partir dos anos de 1920, as quais, mais cedo ou mais tarde, acabariam por chegar também à capital da Bahia. ${ }^{10}$

Os investimentos da Petrobrás e a montagem de plantas industriais na Bahia e em outros estados do Nordeste permitiram a expansão de empresas baianas de construção civil pesada. Essas empresas, das quais o exemplo paradigmático foi a Odebrecht, cresceram, ainda, com o incremento do gasto público com obras de infra-estrutura - estradas, pontes, barragens, abastecimento de água, saneamento e avenidas -, entre o final dos anos 60 e a década de 80. No mesmo período, em Salvador, ocorreram a expansão da construção civil residencial e a valorização da terra urbana nos novos bairros de classe média (Pituba, Caminho das Árvores e outros), ambas impulsionadas pela criação do Sistema Financeiro de Habitação. A expansão residencial, por sua vez, incentivou o desenvolvimento dos serviços imobiliários, dos serviços pessoais e do varejo de bairro, bem como da pequena indústria e do comércio de materiais de construção.

O desenvolvimento do transporte aeroviário no país e o asfaltamento da estrada Rio-Bahia (1963) colocaram Salvador no mapa do turismo nacional: em 1968, foi criada a estatal Bahiatursa - Empresa de Turismo da Bahia. Nos anos seguintes,

\footnotetext{
${ }^{10}$ É necessário evitar, assim, uma concepção excessivamente simplista da modernização dos serviços soteropolitanos na segunda metade do século XX. Dito de forma direta: o Shopping Center Iguatemi, maior shopping do Norte e Nordeste do país, inaugurado em Salvador no ano de 1975, não "resultou" apenas da nova indústria da RMS, como alguns economistas locais pretendem afirmar. $\mathrm{O}$ varejo, como outros segmentos dos serviços, tem também dinâmica própria, e é por isso, por exemplo, que um shopping como o Jequitibá Plaza pode surgir, no ano 2000, em Itabuna, principal pólo comercial da região cacaueira, em plena crise econômica provocada pela vassoura-de-bruxa. A visão convencional mistura uma interpretação mecanicista, do "modelo de base exportadora", com um forte preconceito em relação aos serviços, que supostamente não criariam "valor" e teriam crescimento dependente da renda gerada pela indústria ou pela agricultura (ver, sobre essa questão, Almeida, 1997). Na verdade, isso é desconhecer a própria origem de inovações como o shopping e o supermercado, que se difundiram nos Estados Unidos durante a Grande Depressão de 1929-1938.
} 
a implantação de unidades de cadeias hoteleiras, nacionais e internacionais, eliminaria o gargalo que era a falta de grandes hotéis na cidade, ressalvada a existência do Hotel da Bahia, construído pelo governo baiano e inaugurado em 1949. Assim, em meados dos anos 70 , estavam dadas as condições para o primeiro grande boom do turismo soteropolitano (1974-1979), que resultaria em novos investimentos, com destaque para a construção do Centro de Convenções da Bahia, em 1979, e na consolidação do marketing turístico local, assentado no mix praia/música/carnaval (ver Spinola, 2000).

A educação superior - outro setor vital para a futura economia soteropolitana - também começaria a se desenvolver desde os anos de 1950-70. Em 1946 foi criada a Universidade Federal da Bahia, que cresceu até o final da década de 1970; nos anos 50, surgiram as primeiras faculdades privadas, inclusive a importante Escola Baiana de Medicina; em 1961, implantou-se a Universidade Católica de Salvador; e, em 1972, a FACS, que daria origem, nos anos 90, à UNIFACS, primeira universidade privada e laica do estado. A partir daí, inauguraram-se novas unidades privadas isoladas e, pouco mais tarde, entre 1983 e 1986, uma universidade pública estadual, a UNEB, com campi em várias cidades baianas, inclusive na capital, onde também se localiza sua reitoria. Tais empreendimentos tiveram um múltiplo papel para a economia soteropolitana, qualificando a força de trabalho local, incrementando sua capacidade empreendedora e atraindo recursos públicos federais e estaduais. Além disso, Salvador pôde dar continuidade a uma de suas mais tradicionais vocações: a acolhida de estudantes de outras regiões, que contribuíam para dinamizar não apenas a vida econômica da cidade, mas, também, sua vida cultural. No final dos anos de 1980, a Bahia contava com quase 50 mil estudantes matriculados no $3^{\circ} \mathrm{grau}$, a esmagadora maioria dos quais concentrados em Salvador (ver Almeida, 2002a, 2002b).

É necessário lembrar ainda que, num estado monocêntrico como a Bahia, a capital tendeu a concentrar quase todas as sedes de médias e grandes empresas operando regionalmente. Esse fato teve grande importância para a economia local, na medida em que os centros administrativos empresariais favorecem a expansão dos serviços superiores, criando empregos diretos para trabalhadores altamente qualificados, consumindo serviços empresariais terceirizados e sustentando o turismo de negócios e as viagens profissionais. Ainda que Salvador viesse a perder sedes de importantes organizações no período seguinte (Banco Econômico, Banco do Estado da Bahia, Supermercados Paes Mendonça, Odebrecht), como conseqüência da privatização de empresas públicas estaduais, da globalização e da reconcentração terciária em São Paulo, ela ainda manteria, nesse campo, a primeira posição em relação ao Norte e Nordeste, disputando corpo a corpo com Recife. Em 1990, abrigava 234 sedes empresariais entre as 6.250 mais importantes do país, número que passaria para 264, em um total de 9.131, em 2001, vale dizer, $3 \%$ dos quartéis-generais de empresas do país e $20 \%$ do Norte e Nordeste (ver Almeida; Britto; Mendonça, 2004).

$\mathrm{Na}$ virada do século XX para o século XXI, esse amplo conjunto de atividades industriais e "terciárias" - e não exclusivamente a nova indústria - criou as 
condições para a rápida expansão e diversificação dos serviços empresariais. Como em toda metrópole contemporânea, são esses serviços - business services ou, mais precisamente, business-to-business services (B2B) - que constituirão a coluna vertebral da economia soteropolitana a partir dos anos de 1990. Esse tema será, todavia, desdobrado em outra seção. Por enquanto, o foco será deslocado para 0 impacto das transformações aqui tratadas sobre a inserção espacial de Salvador.

\section{DECLÍNIO DO RECÔNCAVO E FORMAÇÃO DA RMS}

Houve, primeiramente, uma mudança qualitativa nas relações de Salvador com o Recôncavo Baiano - seu arrière-pays imediato. A conclusão e o asfaltamento da BR-116 (1949-63), ligando Salvador às regiões industriais do Centro-Sul do país, e a implantação de uma malha rodoviária no Recôncavo, a partir dos investimentos da Petrobrás, desarticularam as antigas redes de transporte regionais, de base ferroviária e flúvio-marítima. Os investimentos nas fábricas do CIA e do COPEC completaram essa desarticulação, na medida em que reduziram a importância da já declinante economia agroexportadora regional. A decadência do açúcar e do fumo, contemporânea da ascensão do caminhão como principal meio de transporte de carga, marcou também o declínio - emblemático - dos saveiros, dos "vapores" da Companhia Baiana de Navegação e das feiras, que faziam da capital um duplo mercado, de demanda e oferta, para o entorno da Baía de Todos os Santos (BTS). Foram morrendo à míngua os antigos portos dessa orla: Cachoeira, Nazaré, Santo Amaro, Maragogipe. O tiro de misericórdia na navegação tradicional da BTS foi dado pela construção da Ponte do Funil e pela implantação de sistema de ferry-boat, ligando a llha de Itaparica ao continente por via rodoviária, no início dos anos 70 . Cresceram, em contrapartida, as cidades que conseguiram passar de entroncamentos ferroviários para cruzamentos rodoviários - Cruz das Almas, Santo Antônio de Jesus e, sobretudo, fora do Recôncavo, mas ancorada na BR-116 e, mais tarde, também na BR-101, Feira de Santana (ver SEl, 2003).

Abstraindo-se o caso de Feira de Santana, pode-se falar de um deslocamento do centro de gravidade econômico e, conseqüentemente, da hierarquia urbana regional do Recôncavo Sul (cana-de-açúcar) e dos tabuleiros do Paraguaçu (fumo), para os municípios que abrigaram a nova indústria. No Recôncavo Norte, São Francisco do Conde, Candeias, Simões Filho; no Litoral Norte, atlântico, Lauro de Freitas e Camaçari. Como se viu, o deslocamento neste último sentido foi reforçado pela implantação da Estrada do Coco (1975) e da Linha Verde (1993), que asseguraram a multiplicação dos imóveis de veraneio e dos equipamentos turísticos, inclusive grandes resorts internacionais, ao longo da costa.

Decorreu, dessas mudanças, na estruturação do espaço econômico regional, a criação, em 1973, da Região Metropolitana de Salvador, reunindo, em princípio, uma dezena de municípios, mas, de fato, apenas a capital e sua periferia 
industrial (São Francisco do Conde, Candeias, Simões Filho, Camaçari, Dias D'Ávila e Lauro de Freitas). ${ }^{11}$ A RMS passou a ser o lugar privilegiado da intervenção governamental, com o Conselho de Desenvolvimento do Recôncavo, criado em 1967, transformado em Companhia de Desenvolvimento da RMS, com a mesma sigla CONDER - não antes de produzir o primeiro Plano de Desenvolvimento Integrado da nova região. Conseqüência simétrica e indesejada desse processo foi o abandono do Recôncavo e da BTS como espaços de planejamento e de investimento público e privado. A capital da Bahia "deu as costas" ao seu litoral tradicional e seus governantes só se deram conta do erro quando, a partir dos anos de 1990, a necessidade de combater a poluição da baía e a importância da Bahia de Todos os Santos para a náutica de lazer e para o turismo de base ecológica e cultural ficaram evidentes. ${ }^{12}$

Ocorreu, nas mesmas décadas, uma mudança na qualidade dos laços de Salvador com seu hinterland em sentido amplo, as regiões do interior do estado da Bahia. A redução do peso econômico das atividades agropecuárias, que passaram a representar pouco mais de $10 \%$, em média, do PIB estadual, foi um primeiro fator a enfraquecer as relações entre a capital e as regiões mais distantes do estado. Outro elemento de grande significado foi o desvio de parte da emigração rural do estado para as cidades situadas nas suas fronteiras econômicas e geográficas - Barreiras, Juazeiro, Porto Seguro e Teixeira de Freitas, principalmente. Além disso, o desenvolvimento de uma malha rodoviária nacional, o fortalecimento relativo do governo federal e o maior dinamismo econômico de algumas metrópoles situadas em estados vizinhos, contribuíram para reforçar as forças centrífugas exercidas, principalmente, nessas mesmas regiões limítrofes. 0 caso mais evidente foi o dos cerrados do Além São Francisco, ocupados pela soja e pela colonização gaúcha, com vínculos crescentes com o pólo agroindustrial e de serviços do eixo BrasíliaGoiânia. Mas esse tipo de força esteve também presente no São Francisco (Juazeiro/ Petrolina), no Sul e no Extremo-Sul, com seus tradicionais laços com o Espírito Santo e o Rio de Janeiro, bem como no Sudoeste, com suas também tradicionais ligações com a economia mineira. ${ }^{13}$

É necessário levar em conta, ainda, os efeitos espaciais diretos da nova

${ }^{11}$ Os outros municípios da RMS são Vera Cruz e Itaparica, situados na ilha de mesmo nome. Com economia assentada no turismo e no veraneio, responderam, em 2002, por apenas $0,5 \%$ do PIB da região.

${ }^{12}$ Daí o mega projeto Bahia Azul, voltado para a construção de um sistema de saneamento urbano e para o controle da poluição industrial em Salvador e no entorno da BTS, com investimentos de cerca de US $\$ 600$ milhões, bancados pelo BID, Banco Mundial, BNDES e governo estadual, entre outros financiadores. Para mais informações, consultar o site da EMBASA - Empresa Baiana de Águas e Saneamento S.A., em: http://www.embasa.ba.gov.br/a_empresa/bazul.htm.

${ }^{13}$ Um efeito paralelo dessas forças centrífugas é o esvaziamento econômico e populacional de áreas centrais do estado, prejudicadas pelo clima do semi-árido, e dependentes, portanto, de uma agropecuária de baixo dinamismo (e.g. sisal, caprinocultura). 0 turismo, estimulado principalmente na Chapada Diamantina, não se mostrou capaz de assegurar a geração de emprego e renda necessária para reverter esse quadro. Daí a continuidade da probreza e da emigração líquida, que leva, em alguns casos (municípios do Piemonte da Diamantina), à redução absoluta da população. 
indústria e da terciarização na RMS. Como se observou, a indústria baiana se desenvolveu, até os anos de 1990, com base em políticas nacionais de "desconcentração industrial". Tais políticas criaram uma indústria produtora de bens intermediários mais que dependente dos capitais e mercados do Centro-Sul e do exterior do país. Fortes laços econômicos se desenvolveram, a partir disso, com outras grandes cidades e, particularmente, com São Paulo. A chegada de grandes firmas de origem nacional ou estrangeira, a modernização, a desnacionalização e a expansão de empresas locais em vários setores (supermercados, construção civil, telecomunicações, publicidade e outros) reforçaram e aprofundaram os vínculos com outras metrópoles. O desenvolvimento do turismo, nacional e internacional, com Salvador se consolidando não apenas como pólo receptivo, mas também emissor, completou esse novo quadro.

Tais mudanças colocam um duplo desafio para a Salvador do século XXI: para a capital da Bahia, como para toda metrópole contemporânea, as relações econômicas e culturais com outras grandes cidades tendem a se tornar mais importantes do que a preservação dos vínculos tradicionais que a ligam com seu próprio hinterland. A evidência mais material desse fato é a crescente importância do aeroporto (de vocação internacional) da cidade diante dos que eram seus portões de entrada tradicionais para carga e pessoas - o porto e o terminal rodoviário. ${ }^{14}$ Mas, por outro lado, a afirmação de Salvador como metrópole regional passa, antes de tudo, pela hegemonia sobre o seu próprio "interior". Ainda que a posição de pólo da capital seja fortalecida pela inexistência de uma rede estadual de cidades de tamanho médio, a relativa perda de importância dos vínculos sociais e econômicos estabelecidos entre a capital e seu hinterland e as forças centrífugas exercidas por metrópoles vizinhas sobre as fronteiras baianas exigem um novo tipo de soldagem, que vá além daquela criada pelo êxodo rural, o seu comércio e o porto. É possível que a solução venha a estar na exportação intra-estadual de serviços superiores, vale dizer, serviços intensivos em conhecimento, em serviços sociais (saúde, educação superior) ou prestados a empresas.

As transformações que redefiniram a inserção nacional e regional de Salvador na geografia econômica brasileira, na virada do século XX para o XXI, também foram responsáveis por mudanças no espaço econômico interno dessa metrópole. Em Salvador, do mesmo modo que em qualquer grande cidade das últimas décadas do século XX, o processo de diversificação, expansão e modernização dos serviços se materializou espacialmente sob a forma de um novo Central Business District (CDB). $\mathrm{Na}$ capital baiana, o abandono do antigo centro e a migração de organizações públicas e privadas para o novo pólo intra-urbano de serviços foi o resultado de uma intervenção orquestrada pelo governo estadual e pelo grande capital imobiliário local. A ação começou entre o final dos anos 60 e o início da década seguinte. Primeiro, novas

${ }^{14}$ É importante sublinhar que o aeroporto de Salvador era, em 2001, o sexto do país em termos de movimentação de passageiros e o terceiro em carga aérea doméstica movimentada (Almeida, 2003) 
avenidas foram abertas para criar um novo eixo Sul-Norte, que ligasse espaços ainda vazios - mas já apropriados por empresas imobiliárias - ao aeroporto e aos novos bairros residenciais destinados às novas classes médias, assalariadas, da cidade. Em seguida, o governo implantou seu novo núcleo administrativo (o $\mathrm{CAB}$, Centro Administrativo da Bahia) sobre o corredor principal do novo eixo (a Avenida Paralela), a meio caminho entre 0 aeroporto e 0 antigo centro comercial, situado no entorno do porto. Enfim, o Estado e o capital imobiliário instalaram alguns equipamentos estratégicos no coração do futuro CDB: a nova estação rodoviária, um grande shopping center regional, o primeiro hipermercado da capital e alguns dos primeiros prédios de escritórios (ver Scheinowitz, 1998). Começa, então, a migração das empresas do centro histórico. $O$ êxodo, que se inicia na segunda metade dos anos 70 , se acelera nos anos 80 e se completa na década de 90: uma pesquisa, realizada em 2001, revelou que $36 \%$ das firmas do novo CDB tinham começado aí suas atividades, $43 \%$ eram originárias do velho centro $\mathrm{e}$, as outras, na maior parte, eram filiais de empresas oriundas de outras metrópoles brasileiras (Almeida e Norberto, 2001).

Ainda que a implantação do novo CDB tenha sido planejada pelo Estado e pelo grande capital, é importante evitar uma certa visão "conspiratória" desse processo. O fato é que havia se esgotado as possibilidades de expansão para os imóveis empresariais no antigo centro. No início dos anos de 1970, o problema mais citado eram os engarrafamentos nas ruas e avenidas muito estreitas, herdadas do século $\mathrm{XIX}$, quando não do período colonial. Além desse, os empresários locais listavam outros problemas: falta de acessibilidade (estacionamentos), ausência de hotéis, serviços de alimentação e opções de lazer para executivos, distância do aeroporto e, sobretudo, inexistência de espaço disponível para novos prédios de escritórios, não apenas em razão da escassez de grandes terrenos livres, mas, também, em função da presença de áreas de preservação arquitetônica, submetidas à legislação de proteção do patrimônio histórico. Que a transferência dos serviços empresariais tenha se dado por uma linha Sul-Norte atlântica - e não pela alternativa de contornar a BTS, acompanhando a BR-324, que liga Salvador a Feira de Santana, e as BR-116 e 101, no eixo industrial da RMS - parece, nesse contexto, uma solução bastante lógica, haja vista a dependência dos novos serviços em relação ao aeroporto, as ambições turísticas da cidade e a maior valorização imobiliária dos bairros do litoral oceânico da cidade, fator fundamental para empresas dependentes de status e imagem.

Completa-se, assim, a conformação espacial da cidade, sua integração ao seu novo hinterland - a RMS - e sua abertura para novas relações nacionais e internacionais.

Tratou-se, em resumo, como destaca a SEI (2003, p. 157-158), das transformações da rede viária, sobretudo a construção das "avenidas de vale" e da via Paralela, que permitiram a criação de novos bairros residenciais e do novo CDB, deslocando o coração econômico e cultural da cidade, primeiro, para o pólo IguatemiPituba e, mais tarde, na sua extensão norte, também para o eixo Avenida Tancredo Neves-Paralela, sempre em direção ao aeroporto. Acompanhando esse movimento, 
ocorreu a priorização da orla atlântica para os empreendimentos turísticos, a infraestrutura (telecomunicações, iluminação, saneamento) e os investimentos sociais (esporte, lazer, cultura), com "fortalezas de moradia" e "ilhas de excelência" (Porto; Carvalho, 2001), agrupando hotéis, condomínios fechados e shopping centers, entre manchas sempre presentes de bairros proletários, favelas e "invasões". Tratou-se, ainda, da ocupação da orla suburbana da Baía de Todos os Santos, do eixo da BR324 e do "miolo" (os bairros proletários entre os dois vetores de expansão, a BR e a Avenida Paralela), por uma imensa massa de "habitações construídas sem licença oficial", em vales insalubres, encostas e palafitas.

Nesse contexto, resta lembrar que o encarecimento da terra em Salvador levou os novos emigrantes pobres a procurar moradia nas favelas fronteiriças de dois municípios vizinhos - Lauro de Feitas e Simões Filho. $O$ encontro de habitações proletárias daí resultante confirma, de modo perturbador, a conurbação metropolitana.

\section{A ECONOMIA DE SALVADOR ENTRE 1980 E 2005 - IMPACTO DA GLOBALIZAÇÃO E DA REESTRUTURAÇÃO PRODUTIVA}

Pode-se dizer que, no período entre 1950-1980, a Bahia não se industrializou, apesar de ter se tornado o principal pólo industrial do Nordeste e disso ter implicado o fim da hegemonia do capital mercantil regional sobre o processo de acumulação no estado. Vale dizer: não se formou, no estado, um setor industrial com movimento próprio, diversificado e integrado, capaz de acelerar a urbanização, alterar a distribuição do emprego em favor do setor secundário, elevar significativamente 0 nivel da renda regional e redefinir o papel e os métodos de produção da agricultura regional. $O$ desenvolvimento da agroindústria e da produção industrial de bens finais foi limitado: a nova indústria era, basicamente, produtora de insumos e divisas, sustentando-se nas exportações intra-regionais e internacionais de produtos intermediários petroquímicos. Sua evolução estava, desse modo, subordinada à dinâmica da acumulação do grande capital financeiro e industrial concentrado no pólo econômico do país. A nova indústria não eliminou, portanto, o atraso relativo da economia regional diante da economia do "pólo" nacional; ela apenas o repôs num patamar mais elevado. E, como se viu, ela tampouco criou a massa de empregos prometida.

Segundo a Pesquisa de Emprego e Desemprego - PED, a taxa de desemprego aberto em Salvador saltou de 8,9\%, nos anos de 1987-88, para 12,6\%, em 1997-98, e 15,2\%, em 2003-04 (Almeida; Damasceno, 2005a). No conceito de desemprego aberto, que inclui os que não procuram emprego em razão do "desalento", tais porcentagens foram, respectivamente, $15,7 \%, 21,8 \%$ e $26,0 \%$. Isso significa que, no início do século XXI, após meio século de "industrialização", um em cada quatro soteropolitanos estava sem ocupação (ver Almeida; Damasceno, 2005a). Tais taxas fizeram de Salvador a metrópole brasileira recordista em desemprego na virada do 
século e, isso, não apenas segundo a PED, mas também segundo a Pesquisa Mensal de Emprego - PME, do IBGE (ver Almeida, 2002d).

Por que a capital da Bahia, principal pólo industrial do Norte e Nordeste, não conseguia ocupar $1 / 4$ da sua População Economicamente Ativa no início dos anos 2000?

Para responder a essa questão é necessário - mas não suficiente - levar em conta a conjuntura nacional após 1980 . No novo contexto mundial, aberto pelas crises do petróleo (1973-1979), o esgotamento do chamado "modelo de substituição de importações" ficou evidenciado com o fracasso parcial do segundo Plano Nacional de Desenvolvimento (1975-1979). A substituição de importações, financiadas pelo endividamento externo e interno, levou a uma crise que combinou inflação e desaquecimento da economia brasileira. Como a nova indústria baiana dependia, essencialmente, dos capitais e mercados do pólo industrial do país, esse desaquecimento nacional se traduziu em queda significativa das taxas de crescimento dos PIBs da Bahia, da RMS e de Salvador. De fato, a economia baiana, que havia crescido, em média, 8,8\% a.a., no intervalo 1975-1980, cresceu apenas 2,4\% anuais, na década de 1980, e 2,5\% no decênio seguinte. ${ }^{15}$ Estimativas do IPEA confirmam a desaceleração paralela da economia de Salvador a partir de 1985. Entre 1970 e 1985, Salvador esteve entre as metrópoles mais dinâmicas do país, ao lado de Belo Horizonte, Brasília, Porto Alegre, Curitiba, Fortaleza e Belém. Contudo, o crescimento do PIB da capital da Bahia e da sua região metropolitana se desacelerou, em relação aos produtos das capitais mais ativas do país, entre 1985 e 1996, perdendo terreno em relação a Curitiba, Belo Horizonte, Brasília e Fortaleza. Concretamente, e ainda segundo o IPEA, o PIB de Salvador teria crescido, em média, 9,1\% a.a. entre 1970 e $1975,11,3 \%$, em 1975-80, 3,3\%, em 1980-85, 5,7\%, em 1985-90, e apenas $1 \%$, entre 1990 e 1996 (Almeida; Damasceno, 2005b).

Como se sabe, a resposta brasileira ao esgotamento da substituição de importações foi a abertura da economia nacional, a partir de 1990. Isso se traduziu em maior penetração no mercado nacional de produtos e capitais estrangeiros, com as empresas, no Brasil, sendo obrigadas a competir com o produto importado (e contrabandeado), em condições difíceis, haja vista a política de valorização cambial que se radicalizou entre 1994 e 1998. Essa política, além disso, favoreceu a entrada de novas empresas internacionais portadoras de novas tecnologias, inclusive organizacionais, e prejudicou, ao mesmo tempo, as exportações nacionais, como no caso das empresas petroquímicas da Bahia.

0 resultado foi a quebra de muitas empresas brasileiras em vários segmentos. Ramos inteiros, a exemplo da indústria de brinquedos e do complexo têxtil-confecções, estiveram próximos do colapso. Eis uma primeira razão para a destruição do emprego formal: a crise dos setores prejudicados pelas políticas tarifárias

\footnotetext{
${ }^{15}$ Dados da SEl, ver: http://www.sei.ba.gov.br/. Ver também Carvalho JR; Pessoti; Pereira, que registram taxas de crescimento médio anual do PIB baiano de 6,5\% em 1975/86, 0,1\% em 1986/92 e 2,6\% em 1992/00.
} 
e cambiais dos anos 1990-1998. A concorrência externa e o desemprego atingiram tanto os ramos exportadores, quanto os segmentos voltados para o mercado interno, que sobreviviam, até 1990, graças aos subsídios e tarifas protetoras.

Em segundo lugar, ocorreu significativa desnacionalização. A penetração do capital estrangeiro com base na aquisição de empresas nacionais privadas ou estatais resultou também em mais desemprego, pois esse capital trouxe consigo novas tecnologias e novos formatos organizacionais, implicando reengenharia e downsizing das estruturas herdadas. $\mathrm{Na}$ Bahia, como no resto do país, a nova onda de investimento estrangeiro se concentrou em alguns ramos de serviços: telefonia, bancos, supermercados, distribuição de energia elétrica, com impacto negativo sobre a ocupação em alguns desses setores. Note-se, por exemplo, a redução do peso, em Salvador, da ocupação nos serviços financeiros e serviços de utilidade pública (ver Almeida; Damasceno, 2005b).

Em terceiro lugar, a abertura da economia implicou rápida penetração, no Brasil, das novas tecnologias, especialmente das tecnologias da informação e comunicação (TICs), que alteraram tanto as condições de trabalho, quanto a localização do próprio trabalho. Seu impacto sobre a economia local se deu em pelo menos três planos.

Primeiro: empresas e outras organizações modificaram suas estruturas e processos, enxugando seus quadros superdimensionados face às novas tecnologias. Isso provocou grande desemprego, tanto na indústria quanto em segmentos terciários importantes, como serviços financeiros ou grande varejo. Na Bahia, o caso emblemático foi a redução da mão-de-obra direta, empregada no COPEC, para cerca de $1 / 3$ do máximo alcançado nos anos de 1980, com larga utilização de trabalho terceirizado e temporário. Almeida e Damasceno (2005a) confirmam o avanço da terceirização não apenas na petroquímica, mas, também, na indústria metal-mecânica e em alguns importantes ramos de serviços da economia soteropolitana, como financeiros e de utilidade pública. A contrapartida dessa rápida expansão do outsourcing, na economia da RMS, foi a criação de um importante pólo de serviços empresariais em Camaçari e a expansão da oferta desses serviços em Salvador, conforme indica o crescimento dos segmentos de serviços auxiliares e especializados.

Segundo: as novas tecnologias permitiram que empresas e outras instituições se organizassem em redes de fornecedores e clientes operando online e com base no just-in-time, o que implicou elevação da produtividade, redução de custos e economia de força de trabalho. Esse tipo de movimento se processou aceleradamente em diversos setores e segmentos, como no caso das relações entre o grande comércio varejista (supermercados e outros ramos) com seus fornecedores de bens e de serviços (e.g. sistema bancário). A conseqüência mais direta foi a destruição do emprego nos departamentos de retaguarda (back-office) das empresas, com a extinção de postos em áreas como contabilidade, armazenagem etc. Esse processo foi aprofundado, nos anos 2000, com a introdução de unidades de "serviços compartilhados" em grandes organizações, permitindo maiores ganhos de escala nas atividades de retaguarda. 
Finalmente, o uso das TICs, o barateamento das telecomunicações e do transporte, particularmente do aéreo, possibilitaram a relocalização de empresas e a montagem de redes inter-regionais e internacionais de suprimento (global sourcing). Estes últimos movimentos tiveram efeitos contraditórios sobre o mercado de trabalho local. Houve desaparecimento de postos de trabalho, por exemplo, em segmentos do setor financeiro e dos serviços de informática locais. Mas ocorreu, também, a atração de unidades produtivas, sobretudo quando empresas footloose puderam se beneficiar com custos mais baixos de mão-de-obra e incentivos fiscais. ${ }^{16}$

Estima-se que a revolução tecnológica e organizacional tenha eliminado, entre 1990 e 2001, quase 11 milhões de postos de trabalho no Brasil. A abertura às importações, no mesmo intervalo, teria sido responsável por outro 1,5 milhão (ver Freitas; Kupfer; Young, 2004). Ainda que o crescimento (lento) do mercado doméstico e o avanço das exportações (somente a partir de 1999) tenham assegurado um saldo líquido positivo de pouco mais de 3 milhões de postos, esse crescimento não foi, até 2003, suficiente para reduzir as taxas de desemprego no país.

De qualquer modo, no Brasil ou em Salvador, a alta do desemprego só pode ser totalmente explicada quando são também considerados alguns fatores presentes no lado da oferta metropolitana de trabalho. Não se trata, principalmente, como no passado, do êxodo rural. Em Salvador, a proporção de recém-imigrados na PEA (imigrantes com menos de 3 anos de moradia na cidade) vem diminuindo. A PED revela uma proporção de recém-imigrados de 7,2\%, na amostra de 1997-98, e de $6,1 \%$, na de 2003-04 (ver Almeida; Damasceno, 2005). Trata-se, no entanto, do incremento da participação das mulheres na força de trabalho: em Salvador, ainda segundo a PED, de 44,6\%, em 1987-88, para 48\%, em 2003-04. E, sobretudo, do momento particular da demografia, que corresponde às décadas da virada do século, caracterizadas pelo rápido crescimento da quantidade de jovens e adultos jovens em busca de trabalho. Em Salvador, ainda segundo a mesma fonte, as faixas modais de idade da população total estavam entre 10 e 24 anos, em 1997-98, e entre 15 e 29 anos, em 2003-04, reunindo, respectivamente, $33,5 \%$ e $32 \%$ da população local em cada um dos períodos (2005).

Note-se que tais fatores ajudam a explicar os níveis de desemprego na capital da Bahia, mas não explicam o por quê do seu recorde negativo entre as principais metrópoles do país, em boa parte dos últimos quinze anos. Com efeito, todas as causas listadas acima também são válidas para as outras regiões metropolitanas e grandes cidades do país.

\footnotetext{
${ }^{16}$ O termo "footloose" (livre para ir para onde se quer) tem servido para caracterizar a indústria e os segmentos dos serviços que se deslocam em busca de menores custos salariais e incentivos fiscais. Essas empresas têm maior liberdade de localização graças ao avanço da terceirização e subcontratação de serviços, à redução do valor imobilizado em capital fixo e ao uso de mão-de-obra pouco qualificada, num contexto de queda dos custos de transporte e telecomunicação. É o caso típico da indústria calçadista, que abandona o Rio Grande do Sul e São Paulo para se reinstalar na Bahia e no Ceará, ou ainda dos call-centers de telemarketing.
} 
Viu-se que as deformações históricas da estrutura econômica da Bahia e da RMS podem ajudar a compreender o problema: $1^{\circ}$ ) a lenta expansão da agricultura capitalista stricto sensu no estado e a ausência de uma agroindústria dinâmica no hinterland imediato da capital; $2^{\circ}$ ) a ausência de uma base industrial diversificada e uma indústria produtora de bens intermediários, intensiva em capital e pouco integrada à economia local; e $3^{\circ}$ ) a renda pessoal hiperconcentrada (ver Almeida; Damasceno, 2005a, 2005b). É indispensável, contudo, agregar a essas causas dois outros fatores fundamentais: a ausência de uma política local de desenvolvimento e uma política estadual desenvolvimentista descolada da realidade econômica da cidade.

Em resposta ao esgotamento do modelo de substituição de importações, que havia permitido a implantação do COPEC, e ao fim das políticas nacionais de desenvolvimento industrial - um subproduto da crise fiscal brasileira e da hegemonia neoliberal a partir de 1985-90 - o governo baiano limitou-se, praticamente, a aderir à chamada "guerra fiscal". Como em outros estados, essa política obteve algum sucesso, pois ia ao encontro dos interesses de certos ramos industriais, que vinham se tornando cada vez mais footloose, graças à redução de suas necessidades de capital fixo e de giro (novas tecnologias, terceirização) e ao avanço da logística e das telecomunicações no país. Várias empresas industriais, atraídas pelos incentivos fiscais estaduais e pelos baixos salários pagos no Nordeste e, ao mesmo tempo, fugindo de deseconomias de aglomeração presentes no Centro-Sul, notadamente dos sindicatos fortes presentes nos pólos industriais dessa região, deslocaram fábricas para a Bahia. $O$ caso mais evidente foi o da indústria calçadista; o mais espetacular, a atração do novo complexo automobilístico da Ford para Camaçari. Mas essa política atraiu também investimentos em ramos diversos, como montagem eletrônica (as "maquiladoras" do pólo de "informática" de llhéus), confecções, metalurgia, plásticos (com o programa Bahiaplast), celulose e química (inclusive o mega investimento da Monsanto, na produção de defensivos agrícolas em Camaçari).

Embora seja obrigatório reconhecer o relativo sucesso dessa estratégia, é indispensável destacar três pontos: primeiro, a localização dessa nova indústria footloose é descentralizada e/ou interiorizada, salvo exceções. Isso significa que ela impacta indiretamente sobre a economia de Salvador e o faz, sobretudo, reforçando o peso dos business services na capital ${ }^{17}$; segundo, essa política tende a ter resultados declinantes, na medida em que é imitada por todos os estados brasileiros e se torna uma ameaça ao equilíbrio fiscal, haja vista que a "guerra" só pode ser vencida com incentivos e concessões cada vez maiores; e, terceiro, até por conseqüência, ela não soluciona o problema, que é definir uma nova política de desenvolvimento econômico para uma metrópole de 3 milhões de habitantes, com a economia centrada em serviços.

\footnotetext{
${ }^{17} \mathrm{~A}$ desconcentração espacial da indústria talvez possa explicar a participação declinante das capitais brasileiras no PIB nacional, bem como o caso excepcional de Manaus, que continua concentrando a montagem eletrônica da sua Zona Franca. Com efeito, muito se falou do dinamismo de pólos no interior dos estados na virada do século, que teriam sido alavancados pelo boom do agronegócio e pela indústria footloose.
} 
Da Cruz e Menezes (2000) calcularam que, em 1998, 82\% do PIB de Salvador era gerado por atividades terciárias, sendo o comércio responsável por cerca de $12 \%$ e, os serviços, em sentido estrito, por $70 \%$. Os mesmos autores descobriram ainda que, em Salvador, o crescimento do peso dos serviços no produto local ocorria, principalmente, em quatro segmentos: (a) hotelaria e serviços de alimentação; (b) transporte, armazenagem e comunicações; (c) serviços financeiros; e (d) serviços empresariais, vale dizer, business services. Dados mais recentes do IBGE e da PED confirmam, a grosso modo, essa distribuição. Segundo o IBGE (2005), os serviços já respondiam por mais de 75\% do PIB de Salvador, em 2002 (Almeida; Damasceno, 2005b). De acordo com a PED, serviços e comércio seriam responsáveis por $87,4 \%$ da ocupação na capital da Bahia, em 2003/04 (2005b). ${ }^{18}$

Apesar da evidente terciarização da economia soteropolitana, a visão industrialista tradicional, ainda hegemônica na Bahia, continuou a ver, nessa expansão dos serviços, uma evidência do atraso econômico da cidade. Loiola (1997, p. 23) lembra que, em razão da "longa hegemonia do paradigma industrializante, que fez da indústria o único vetor de desenvolvimento e modernidade, firmou-se, nos meios intelectuais e políticos [baianos], um acentuado ceticismo quanto ao futuro [de Salvador]". A especialização da cidade na produção de serviços era vista como fonte de problemas e não de oportunidades. O próprio Poder Público Municipal teria sido influenciado por esse tipo de visão. "A sua omissão quanto aos rumos do desenvolvimento econômico da cidade sempre foi justificada com base no argumento de que os fatores que poderiam estimular a economia, isto é, o setor secundário, não estavam sob seu controle."

É indiscutível o papel dos novos investimentos industriais para o incremento do produto da RMS. Somente o Complexo Amazon, da Ford, e seus desdobramentos devem implicar um impacto equivalente a algo entre $5 \%$ a $13 \%$ do PIB baiano, por volta de 2006 (Alban, 2000). Dito isso, é necessário reafirmar que o foco de uma estratégia de desenvolvimento para Salvador não pode ser o crescimento industrial. Os dados de estudos, como os de Da Cruz e Menezes, comprovam o que seria de se esperar para uma metrópole regional - a economia de Salvador é uma economia de serviços em transição de atividades de consumo corrente e local para atividades superiores exportáveis: serviços prestados às empresas, serviços sociais (saúde e educação), produção de conhecimento, cultura e turismo.

Felizmente, com 0 acúmulo das evidências, políticos e estudiosos de Salvador começaram a se convencer, ainda que lentamente, de que é possível pensar o desenvolvimento da cidade de forma relativamente autônoma, em relação ao parque industrial da RMS. A tradicional intervenção do governo estadual nos segmentos do turismo e entretenimento (reforçada pelo recente apoio ao seu clustering) e sua política de incentivos fiscais para a atração de empresas de telemarketing (call centers) foram

${ }^{18}$ Os trechos seguintes deste texto estão largamente baseados em três dos nossos mais recentes trabalhos sobre a terciarização de Salvador. Ver Almeida (2002d, 2004a) e Almeida; Damasceno (2004). 
dois exemplos de políticas alternativas, baseadas em vetores de serviços. Trata-se de seguir adiante nessa direção e, tendo em vista seu papel essencial, propor uma política específica para os segmentos de serviços prestados às empresas e, notadamente, para os serviços empresariais intensivos em conhecimento.

A opção por um enfoque em serviços superiores é uma decisão vital para o futuro da cidade. Do ponto de vista econômico e cultural, Salvador já é uma das duas principais metrópoles do Nordeste. Tem condições de manter e consolidar essa posição e, mesmo, ultrapassar Recife. Se não pode ambicionar o posto de cidade global do país, dividido entre São Paulo e Rio de Janeiro, pode se tornar a terceira metrópole gateway brasileira, sobretudo, se consolida sua vocação de centro turístico e cultural, firmando-se como portão (e portal) de entrada para o Norte e Nordeste do país.

No entanto, uma política de sustentação, ao desenvolvimento local, de serviços superiores ou estratégicos não pode ficar limitada aos instrumentos tradicionais utilizados na chamada guerra fiscal, até aqui voltada basicamente para a atração de indústrias. Philippe, Léo e Boulianne (1998) e Philippe e Léo (1999), entre outros, chamaram a atenção para as dificuldades de construir uma política de "descentralização terciária".

De fato, em primeiro lugar, é necessário reconhecer que o relativo sucesso das políticas de atração de indústrias com base em incentivos fiscais se deveu, também, a um fato objetivo: empresas de alguns ramos industriais (e.g. calçados, montagem eletrônica) tendiam, de fato, à migração, pois pretendiam fugir das deseconomias de aglomeração e dos custos presentes em suas regiões de origem. Isso não ocorre com os serviços, particularmente com os superiores. Ao contrário, eles são, em geral, muito mais dependentes de economias de aglomeração e de uma infra-estrutura sofisticada, que só encontram nas maiores cidades. A idéia de que 0 desenvolvimento das novas tecnologias de informação e comunicação permitiria a migração de organizações produtoras de serviços para cidades de porte médio ainda está para ser comprovada. Há exceções e casos isolados, é claro. De qualquer modo, os parâmetros de decisão locacional de organizações produtoras de serviços superiores vão muito além do custo direto stricto sensu. 0 mesmo pode-se dizer, ainda com mais razão, no que diz respeito às sedes de grandes empresas. $E$, aliás, como se mostrou acima, a implantação do novo CDB de Salvador é uma forte evidência da importância desses outros fatores locacionais, que vão da proximidade de um grande aeroporto à imagem internacional da cidade.

Em segundo lugar, nos casos em que a atração é possível, por exemplo, nas operações de back-office, como telemarketing e processamento de dados, 0 caráter footloose dos serviços estandardizados aumenta o risco de políticas exclusivamente centradas em vantagens fiscais. Como lembram os autores citados, "[...] a extrema mobilidade dos serviços empresariais condena antecipadamente este tipo de política ao fracasso: a entrega de prêmios para [a localização no] território não garantiria em nada implantações estáveis" (Philippe; Léo; Boulianne, 1998).

Levando em conta esses obstáculos, a literatura internacional tem procurado 
desenhar uma estratégia alternativa para cidades de "segundo nível", baseada em dois ou três vetores e um foco bem determinado, que é a ênfase na expansão e diversificação da base de serviços empresariais já existentes. No caso de Salvador, vetores de grande potencial podem vir a ser serviços sociais exportáveis, como saúde de maior complexidade e ensino superior, além da expansão das atividades do seu complexo cultura/turismo/entretenimento, de dinamismo comprovado.

\section{O FUTURO DA ECONOMIA SOTEROPOLITANA: serviços superiores, conhecimento e cultura}

Segundo o IBGE, com pouco mais de 2,6 milhões de habitantes, em 2004, Salvador é a terceira cidade mais populosa do país. Cresce à taxa de 1,9\% ao ano: mais rápido que Recife e Belo Horizonte, mas a uma velocidade inferior a de Fortaleza e Brasília. A capital da Bahia comanda a sétima mais populosa região metropolitana do Brasil, a RMS, com quase 3,3 milhões de habitantes (Almeida; Damasceno, 2005b).

A RMS era, de acordo com o IBGE, em 2002, a quinta região metropolitana do país e a primeira do Nordeste em termos de criação de valor, com um PIB de cerca de $R \$ 31$ bilhões, a preços do ano, vale dizer US\$11,5 bilhões, à taxa de câmbio de US\$ 1 para R $\$ 2,70$. Salvador, segundo a mesma fonte, era o nono PIB entre as capitais do país no mesmo ano, com $\mathrm{R} \$ 9,3$ bilhões ou US $\$ 3,4$ bilhões (idem).

Note-se que todas essas estimativas, que confirmam Salvador e sua região metropolitana como um dos principais pólos econômicos do país e a mais importante economia metropolitana do Nordeste, estão significativamente subestimadas, principalmente porque ainda não incorporam o impacto direto e indireto sobre o PIB regional da Ford em Camaçari.

É claro que a importância do produto da RMS, em termos nacionais (pouco mais de $2 \%$ do PIB brasileiro) e, sobretudo, em termos regionais (maior PIB metropolitano do Nordeste), deve ser relativizada em face da pobreza da maioria da população e da extrema desigualdade socioeconômica que caracterizam Salvador e sua região metropolitana. A RMS apresentava, em 1999, um dos piores índices de desigualdade entre dez das mais importantes regiões metropolitanas do país. Além disso, o rendimento médio da população era bem inferior ao verificado nas capitais do Sudeste e Sul do país (idem). Essa situação não se alterou nos primeiros anos do século XXI: pelo contrário, como mostra a PED, os rendimentos médio e mediano mensais da população soteropolitana voltaram a cair, entre o final dos anos 1990 e o início da década seguinte, quando atingiram, respectivamente, os níveis de $R \$ 798,5$ e R\$ 401,00 (Almeida, Damasceno, 2005a).

Além disso, se a taxa de informalidade, da população ocupada em Salvador, parece ter se estabilizado, com o crescimento recente da proporção de trabalhadores assalariados com carteira assinada, ela o fez no patamar elevado que a precarização do trabalho impôs nas duas últimas décadas (2005a). Na RMS e em Salvador, 45\% 
da força de trabalho estava na informalidade, no intervalo de 2003-04 (ou seja, era assalariada, sem carteira, ou autônoma, sem previdência social).

Apesar da informalidade, da desigualdade e independente dos níveis de renda médios per capita, que são baixos numa capital nordestina como Salvador, o tamanho absoluto da população, sua densidade e sua velocidade de crescimento em torno de $1 \%$ ao ano nas próximas duas décadas, conforme prevê o novo Plano Diretor da cidade (ver PMS/SEPLAM, 2004) -, constituem, por si só, um indicador do seu potencial econômico. Como já se enfatizou neste texto, grandes cidades constituem grandes mercados, porque concentram população e criam, assim, condições para 0 desenvolvimento da chamada economia de urbanização: pequenas indústrias de alimentos, vestuário ou mobiliário residencial, comércio varejista, prestação de serviços pessoais, serviços de alimentação etc. A análise da estrutura econômica da RMS parece indicar um déficit considerável, particularmente no que concerne às indústrias de bens de consumo finais leves, embora seja possivel que existam possibilidades inexploradas de substituição de importações regionais desses bens (e.g. confecções, mobiliário doméstico). Além disso, a economia de urbanização local continua a ser um poderoso fator de atração para investimentos de empresas de serviços nacionais e internacionais: cadeias de supermercados, franquias de varejo, redes de restaurantes fast-food etc. (ver Almeida, 2002d).

Porém, quando se trata de serviços estratégicos, os que importam não são os serviços de urbanização, destinados ao consumo final e à demanda local. É necessário insistir nesse ponto: o que interessa, estrategicamente, para a metrópole soteropolitana são três tipos de serviços:

- Business services, isso é, serviços de consumo intermediário, que asseguram uma infra-estrutura capacitada a atrair e manter investimentos, entre os quais se destacam os serviços empresariais, intensivos em conhecimento;

- Turismo de lazer e de negócios, incluindo dois dos seus segmentos mais dinâmicos - o turismo cultural e o de eventos;

- Serviços sociais de consumo coletivo, que podem ser crescentemente exportados para outras regiões da Bahia e, mesmo, para outros estados, notadamente nas áreas de educação (ensino superior) e saúde (pólo médico).

São esses os setores da nova economia de serviços que podem levar Salvador, que já é uma das duas maiores metrópoles do Nordeste, da condição de centro terciário para a situação de centro nacional exportador de serviços superiores, cultura e conhecimento; para a condição de uma economia metropolitana quaternária ou quinária, baseada na gestão e difusão da informação e na geração de conhecimento, que pode expandir sua área de hegemonia no Nordeste e, até, sobre outras regiões do país. ${ }^{19}$

\footnotetext{
${ }^{19}$ No sentido dado por Foote e Hatt (1953): atividades quaternárias são entendidas como aquelas que se referem à produção e ao tratamento da informação ou, como se diz atualmente, fundadas nas TICs; e, as quinárias, como aquelas que se dedicam à produção de conhecimento e são englobadas, hoje, nas chamadas "indústrias criativas".
} 
Metrópoles regionais, como Salvador, são centros de produção de serviços diversificados. São pólos de poder político regional, abrigando organizações governamentais e centros de decisão de grandes e médias empresas. São centros de comércio nacional e internacional e de atividades de serviços de diversos tipos, tanto daquelas que produzem para o consumo pessoal, quanto daquelas que fornecem insumos intangíveis para empresas. São, também, pólos de educação superior e de produção de arte, cultura e entretenimento. Dessa forma, são ainda centros turísticos e, particularmente, de turismo de negócios - business tourism.

Para Salvador, metrópole regional no século XXI, uma política de desenvolvimento baseada nos serviços superiores é necessária por razões de ordem estratégica. A expansão dos serviços e suas novas relações com a indústria tendem a redefinir a hierarquia das regiões, com os territórios que concentram os serviços superiores - financeiros, empresariais e sociais - dominando aqueles especializados em funções industriais e serviços tradicionais (Ughetto; Du Tertre, 2000). Se Salvador pretende continuar mantendo o seu posto de metrópole regional, será preciso insistir nesse caminho.

\section{REFERÊNCIAS}

AGUIAR, Pinto de. Notas sobre o enigma baiano. Salvador: Progresso, 1958. (Série CPE desenvolvimento econômico e regional).

ALBAN, Marcus (Coord.); SOUZA, Celina; FERRO, José R. O Projeto Amazon e seus impactos na RMS. Salvador: SEPLANTEC/SPE, novembro de 2000.

ALMEIDA, Paulo Henrique de. Produtividade e improdutividade dos serviços na história do pensamento econômico. Bahia Análise \& Dados, Salvador: SEI, v. 6, n. 4, p. 20-26, mar.1997.

O mercado de ensino superior privado Brasil e Bahia. Relatório de pesquisa. Salvador: UFBA/ DESENBAHIA, 2002a. Fotocopiado.

. A expansão recente do ensino superior privado no Brasil e na Bahia. Bahia Análise \& Dados, Salvador, v. 12, n. 3, p. 143-157, 2002b.

. Pequena empresa e desenvolvimento local - os limites da abordagem competitiva. In: FISCHER, Tania (Org.). Gestão do desenvolvimento e poderes locais: marcos teóricos e avaliação. Salvador: Casa da Qualidade, 2002c. p. 245-60.

Salvador 2002 - esboço de uma nova política de desenvolvimento. Relatório de pesquisa. Salvador: UFBA/PMS, 2002d. Fotocopiado.

Serviços estratégicos para o desenvolvimento. In: SEl. Serviços estratégicos na Região Metropolitana de Salvador. Salvador: 2004a, p.29-46 (Série estudos e pesquisas, 70).

Aeroportos e desenvolvimento local - o caso de Salvador. In: SEI. Serviços estratégicos na Região Metropolitana de Salvador. Salvador: 2004b. p.-107-135 (Série estudos e pesquisas, 70).

; BRITTO, Elissandra; MENDONÇA, Joseanie. Sedes empresariais e serviços superiores - 0 caso da Bahia. In: SEl. Serviços estratégicos na Região Metropolitana de Salvador. Salvador: 2004. p.63-74 (Série estudos e pesquisas, 70).

; DAMASCENO, Luciano. Perfil sócio-econômico do trabalhador informal de Salvador - 2005.

Relatório parcial de pesquisa. Salvador: UFBA/SEPLAM-PMS, 2005a. Fotocopiado. 
. A economia de Salvador em 2005. Relatório parcial de pesquisa. Salvador: UFBA/ SEPLAM-PMS, 2005b. Fotocopiado.

Serviços estratégicos na Região Metropolitana de Salvador. In: SEl. Serviços estratégicos na Região Metropolitana de Salvador. Salvador: 2004, p. 47-62 (Série estudos e pesquisas, 70).

NORBERTO, Elaine. Tertiarisation, services aux entreprises et proximité: le cas de Salvador de Bahia. In: LES TROISIEMES JOURNEES DE LA PROXIMITE - NOUVELLES CROISSANCES ET TERRITOIRES, 2001, Paris. Disponível em: http://www.jm.u-psud.fr/ adis/rubriques/p/prox/c20-2.pdf. Acesso em: ?

ALMEIDA, Rômulo de. Rômulo voltado para o futuro. Fortaleza: BNB, 1986.

AVENA FILHO, Armando. O Estado mono industrial: as mudanças na composição do produto industrial baiano. Informe Conjuntural, Secretaria do Planejamento, Ciência e Tecnologia, Salvador, n.19, p.63, fev. 1983.

AZEVEDO, José Sergio Gabrielli de. Industrialização e incentivos fiscais na Bahia: uma tentativa de interpretação histórica. 1972. Dissertação (Mestrado) - Faculdade de Ciências Econômicas da UFBa, Salvador.

AZEVEDO, Thales de. $O$ advento da Petrobrás no Recôncavo. In: BRANDÃO, Maria de Azevedo (Org.). Recôncavo da Bahia: sociedade e economia em transição. Salvador: Fundação Casa Jorge Amado; Academia de Letras da Bahia; Universidade Federal da Bahia, 1998. p.185-216.

\section{9. $271 \mathrm{p}$.}

; LINS, E. Q. Vieira. História do Banco da Bahia 1858-1958. Rio de Janeiro: José Olympio,

BNB. Banco do Nordeste do Brasil. História - a empresa. Disponível em: http://www.bnb.gov.br/Content/ aplicacao/O Banco/Historico/gerados/hist_principal.asp. Acesso em: jul. 2005.

BORBA, Silva Fraga Costa. Industrialização e exportação do fumo na Bahia: 1870-1930. 1975. Dissertação (Mestrado) Faculdade de Ciências Econômicas da UFBA. Salvador

; SANTOS, Luiz Chateaubriand dos. Fumo. In: CPE. Centro de Pesquisas e Estudos. Ainserção da Bahia na evolução nacional - $1^{a}$ etapa: 1890-1930. Atividades produtivas. Salvador: Secretaria Estadual do Planejamento, Ciência e Tecnologia, 1978. 298 p.

BORGES, Ângela. Sobre o atraso do processo de urbanização na Bahia. Bahia Análise \& Dados, Salvador, SEI, v. 3, n. 2, p. 57-71, set. 1993.

CANO, Wilson. Raízes da concentração industrial em São Paulo. São Paulo: Difusão Editorial. 1977.

. Desequilibrios regionais e concentração industrial no Brasil - 1930/1970. 1981 Tese (Livre Docência). DEPE, IFCH, Unicamp Campinas.

CANUTO, Tibério. A industrialização na Bahia. Cadernos do CEAS, Salvador, n. 45, p. 13-20, set./out. 1976.

CARVALHO JR., César Vaz; PESSOTI, Gustavo Casseb; PEREIRA, Ítalo Guanais Aguiar. Panorama da economia baiana sob a ótica do PIB - 1975-2000. In: SEI. Dez anos de economia baiana. Salvador: 2002. p. 7-23.

CASTRO, Antônio Barros de. Sete ensaios sobre a economia brasileira. Rio de Janeiro: Forense, 1971. $2 \mathrm{v}$.

CAVALCANTE, Luiz Ricardo Mattos Teixeira. Crédito e desenvolvimento regional: o caso do Banco de Desenvolvimento do Estado da Bahia. 2004. 235f. Tese (Doutorado em Administração) - UFBA, Salvador. CEPLAB - Centro de Planejamento da Bahia. Governo da Bahia. Economia baiana - subsídios para um plano de governo. Salvador: Secretaria Estadual do Planejamento, Ciência e Tecnologia. 1978. t.3/4. CONDER - Conselho de Desenvolvimento do Recôncavo. Estudos básicos para o projeto agropecuário do Recôncavo. Salvador: Secretaria Estadual do Planejamento, Ciência e Tecnologia 1973 t.1. 
CPE. Fundação Centro de Pesquisas e Estudos. A inserção da Bahia na evolução nacional - $2^{a}$ etapa: 1890-1930. Salvador, Secretaria de Planejamento, Ciência e Tecnologia, 1980.

DA CRUZ, Rossine Cerqueira (Coord.); MENEZES, Sérgio. Cenários sócio-econômicos para a cidade de Salvador. Feira de Santana: UEFS/Salvador: PMS/SEPLAM, 2000. Fotocopiado.

DINIZ, Marcelo B.; ARRAES, Ronaldo A. Trajetória recente da desigualdade de renda nas regiões metropolitanas do Brasil. In: CONGRESSO DE BRASILEIRO DE ECONOMIA, 15, 2003, Brasília, Disponível em: http://www.unioeste.br/cursos/cascavel/economia/xv_cbe/010.pdf Acesso em: 01/02/2004.

FOOTE, Nelson N.; HATT, Paul K. Social mobility and economic advancement. American Economic Review, Princeton, v. 43, n. 2, p. 364-379, maio 1953.

FREITAS, Fabio; KUPFER, David; YOUNG, Carlos Eduardo. Decomposição estrutural da variação do produto e do emprego entre 1990 e 2001 - uma análise a partir das matrizes insumo-produto. Rio de Janeiro: Instituto de Economia da UFRJ, Grupo de Indústria e Competitividade, Jan. 2004. Relatório parcial de pesquisa. Disponivel em: http://www.ie.ufrj.br/gic/pdfs/ decomposicao_estrutural_da_variacao_do_produto_e_do_emprego.pdf Acesso em: set. 2005.

GUERRA, Oswaldo. A indústria baiana no século XXI: desafios e oportunidades. Salvador: UNIFACS, IPA, DCSA 2, Programa de Pós-graduação em Desenvolvimento Regional e Urbano - desempenho atual e tendências da indústria baiana. Texto de Análise do Desenvolvimento Regional, n. ${ }^{\circ} 4$, maio de 2001.

; TEIXEIRA, Francisco. 50 Anos da industrialização baiana: do enigma a uma dinâmica exógena e espasmódica. Bahia Análise \& Dados, Salvador, SEI, v. 10, n. 1, p. 87-98, jul. 2000.

HALL, Peter. Megacities, world cities and global cities. The Hague: Megacities Foundation, 1997. Disponivel em http: //www.megacities.nl/lecture_hall.htm. Acesso em: ?

HIRSCHMAN, A. O. The strategy of economic development. New Haven: Yale University Press, 1958. IBGE. Censo demográfico de 1980. Rio de Janeiro: IBGE, 1983.

. Censo demográfico de 1991. Rio de Janeiro: IBGE, 1994. Censo demográfico de 2000. Rio de Janeiro: IBGE, 2002.

Produto Interno Bruto dos Municípios, 1999-2002. Rio de Janeiro: IBGE, 2005. Disponível em: http://www.ibge.gov.br Acesso em: ?

LOIOLA, Elisabete. Entre o barroco das igrejas e o pós-moderno dos serviços: a questão do desenvolvimento da Cidade da Bahia. Bahia Análise \& Dados, Salvador, SEI, v. 6, n. 4, p. 20-26, mar. 1996.

MALUF, Renato S. Ações públicas locais de abastecimento alimentar. São Paulo: Instituto Pólis, abril de 1999. Disponível em: http://www.polis.org.br/obras/arquivo_172.pdf Acesso em: agosto de 2005.

MARIANI, Clemente. Análise do problema econômico baiano. O Observador, [S.I.]. v. 23, n. 267, p.1641, maio 1958.

MARSHALL, Alfred. Trade and industry: a study of industrial technique and business organization, and of their influences on the conditions of various classes and nations (1919). 4.ed. New York: A. M. Kelley, 1970.

Princípios de economia (1900). São Paulo: Abril Cultural, 1982.

OLIVEIRA, Francisco; REISCHSTUL, Henri-Philippe. Mudanças na divisão inter-regional do trabalho no Brasil. CEBRAP, São Paulo, v. 4, n. 131, abr./jun. 1973.

OLIVEIRA, Waldir Freitas. História de um banco - o Banco Econômico. Salvador: Museu Eugênio Teixeira Leal/Memorial do Banco Econômico, 1993. 375 p.

PERROUX, François. Economic spaces: theory and application. Quarterly Journal of Economics, [S.I.], 1950. 
Note on the concept of growth poles. Economie Appliquée, [S.I.], v. 8, 1955.

PHILIPPE, Jean ; LEO, Pierre-Yves ; BOULIANNE, Louis-M. (Orgs.). Services et métropoles - formes urbaines et changement économique. Paris: L'Harmattan, 1998.

Activités de services et métropoles: constats et interrogations. Canadian Journal

of Regional Science/Revue Canadienne des Sciences Régionales, [S.I.], v. 22, n. 3, p. 315-325, autumn/ automne, 1999.

PMS/SEPLAM. Prefeitura Municipal de Salvador. Secretaria Municipal do Planejamento, Urbanismo e Meio Ambiente. Plano Diretor de Desenvolvimento Urbano - PDDU. Salvador: 2004. Disponível em: http://www.seplam.pms.ba.gov.br/pddua. Acesso em: julho de 2005.

PORTO, Edgard; CARVALHO, Edmilson. Salvador na "globalização". EURE, Santiago, v.27, n.-80, p.163-18. maio 2001,

PRADO JÚNIOR, Caio. História econômica do Brasil. 12. a ed. São Paulo: Brasiliense, 1970. 354 p.

RITZ, Armin. Fenômenos de dependência na economia baiana. Cadernos do CEAS, Salvador, n. ${ }^{\circ} 22, \mathrm{p}$. 18-32, dez. 1972.

SANTOS, Milton. O centro da cidade do Salvador. Salvador: Livraria Progresso, [19-?].

. O papel metropolitano da cidade do Salvador. Revista Brasileira dos Municípios, Rio de Janeiro, v. 9, n. 35/36, 1954.

SCHEINOWITZ, A. S. O macroplanejamento da aglomeração de Salvador. Salvador: Secretaria da Cultura e Turismo/EGBA, 1998.

SEI. Bahia em números. Salvador: SEI, 2002. v. 4.

Dinâmica sociodemográfica da Bahia: 1980-2002. Salvador: 2003. v. 2. (Série estudos e pesquisas, 60).

SOUZA, Guaraci Adeodato Alves de. Urbanização e fluxos migratórios para Salvador. In: ;FARIA, Vilmar (Orgs.). Baía de todos os pobres. Petrópolis: Vozes/CEBRAP, 1980.

SPINOLA, Carolina. O PRODETUR e a descentralização do turismo baiano. Revista de Desenvolvimento Econômico, Salvador, v.2, n. 3, p. 36-47, jan. 2000.

SPINOLA, Noélio Dantaslé. A implantação de distritos industriais como política de fomento ao desenvolvimento regional: o caso da Bahia. Revista de Desenvolvimento Econômico, Salvador, v. 3, n. 4, p. 28-48, jul. 2001.

SZMRECSÁNYI, Tamás. O planejamento da agroindústria canavieira do Brasil (1930-1975). São Paulo: Hucitec, 1979.

. Crescimento e crise da agroindústria açucareira do Brasil, 1914-1939. Revista Brasileira de Ciências Sociais, São Paulo, v. 7, n. 5, jun., p. 32-68, 1988.

TAVARES, Luiz Henrique Dias. O problema da involução industrial da Bahia. Salvador: UFBA, 1966.

UGHETTO, Pascal ; DU TERTRE, Christian. Services, espace et territoires: un aperçu de quelques problématiques de recherche. Paris: IRIS, Université Paris IX, 2000. Fotocopiado. 


\title{
CONDIÇÕES DEMOGRÁFICAS
}

\author{
Cláudia Monteiro Fernandes*
}

Salvador é a terceira cidade mais populosa do país e comanda a sexta região metropolitana brasileira em termos demográficos. Sua participação na população residente na Bahia veio crescendo na última década. Observando o período intercensitário, a população residente na Região Metropolitana de Salvador - RMS, representava $21,0 \%$ do total da população residente no estado da Bahia, em 1991, e passou a constituir $23,1 \%$ em 2000 , o que significa um incremento superior a um milhão de pessoas residentes na metrópole. De acordo com as projeções populacionais do IBGE, para os anos 2003 e 2004, a participação da população da RMS no total da Bahia continuará a crescer, atingindo 23,7\% em 2003 e 24,2\% em 2004.

$\mathrm{Na}$ área polarizada pela capital baiana, o processo descrito como "desmetropolização" por Martine (1993) teve características diferentes daquelas observadas em metrópoles como São Paulo e Rio de Janeiro. É verdade que houve uma desaceleração no ritmo de crescimento da participação da população metropolitana no total da população do estado da Bahia, mas essa participação continuou a crescer. Essa dinâmica está relacionada com a expulsão de pessoas do interior do estado para outros estados e regiões, mais que proporcionalmente à migração de pessoas do interior para a metrópole, que continua recebendo emigrantes.

Também o processo de "periferização" na RMS tem suas características próprias. $O$ destacado crescimento de municípios como Lauro de Freitas foi fortemente influenciado pela instalação de pessoas de melhor poder aquisitivo, provindas de Salvador ou de metrópoles do Sul e Sudeste, que migram em condições bem melhores que aquelas que vêm do interior do estado. Essa "periferização" gerou melhores condições de habitações (com a construção de condomínios para as classes média e média alta) e melhores indicadores de educação e rendimentos nesse município,

* Mestre em Ciências Sociais pela Universidade Federal da Bahia. Membro da equipe técnica do UNICEFSalvador. 
pois os novos moradores chegam com trabalhos garantidos em empreendimentos industriais do Pólo Petroquímico e em novas empresas, instaladas com vantagens fiscais.

O próprio Martine (1993) já havia observado essa dinâmica diferenciada, apesar de destacar motivos diferentes à época. Quando tratou das taxas de crescimento populacional até a década de 1990, afirmou que "restam, portanto, apenas duas RMs nordestinas - Fortaleza e Salvador - que, embora sofressem redução significativa no seu ritmo de crescimento, ainda apresentavam taxas acima de $3 \%$ a.a. Evidentemente, esses dois casos refletem padrões mais tradicionais de crescimento vegetativo e de migração".

Em termos de densidade populacional, o estado da Bahia apresenta uma nítida concentração espacial de sua população na Região Metropolitana e grandes espaços com baixíssima densidade demográfica - os ditos "vazios" populacionais -, sobretudo em áreas da região semi-árida e do sertão, o que leva à manutenção dos padrões mais tradicionais de dinâmica populacional. Em 2000, a densidade demográfica do estado da Bahia era de 23,15 habitantes por km²: a concentração da população na metrópole fica clara, com a densidade média de 1.065 habitantes por $\mathrm{km}^{2}$ nos dez municípios da RMS, em 2000, 46 vezes superior à densidade média do estado.

No entanto, é importante destacar que a grande dimensão espacial do estado da Bahia torna problemática a comparação com o grau de concentração da população em outras regiões metropolitanas. Exemplificando, em regiões metropolitanas como o Rio de Janeiro, que faz parte de um estado com área bem menor que a Bahia, é evidente o peso expressivo da população metropolitana no total do estado. Na Bahia, apesar dos quase "vazios" populacionais do semi-árido, a área em que se distribui a população é bem maior, com uma "pulverização", sem maiores concentrações em cidades consideradas como "médias".

Dentro da região metropolitana o município de Salvador é o que detém maior população residente e também maior densidade demográfica. Em 2000, eram 3.457 habitantes por $\mathrm{km}^{2}$ e 2,4 milhões de pessoas residentes, conforme dados do Universo do Censo. Salvador tem a segunda maior área entre os dez municípios da sua região metropolitana, superado apenas por Camaçari que, por sua vez, tem a segunda maior população residente - eram 162 mil pessoas residentes em 2000, população 15 vezes menor que a do município de Salvador no mesmo período, apesar de possuir maior área. Salvador tem a maior dinâmica econômica, cultural e histórica do estado e, Camaçari, abriga o Pólo Petroquímico.

Lauro de Freitas era o município com a segunda maior densidade demográfica da região metropolitana, com 1.895 habitantes por $\mathrm{km}^{2}$ em 2000, e também o terceiro município mais populoso da região, com 113,5 mil residentes no mesmo período. A densidade é elevada, numa área que é a segunda menor entre os municípios da RMS $\left(59,9 \mathrm{~km}^{2}\right)$, superior apenas à área de Madre de Deus $\left(11,1 \mathrm{~km}^{2}\right)$ que, por ser fisicamente menor, possui a terceira maior densidade demográfica da região. 
Tabela 1 - População censitária, população estimada, área e densidade demográfica, segundo os municípios Bahia e Região Metropolitana de Salvador, 1991, 2000, 2002 e 2003

\begin{tabular}{|c|c|c|c|c|c|c|c|c|c|}
\hline \multirow{2}{*}{ Bahia, RMS e Municípios } & \multirow{2}{*}{1991} & \multirow{2}{*}{2000} & \multirow{2}{*}{$\begin{array}{c}\text { População Estimada } \\
2002 \\
(01 / 07 / 02)\end{array}$} & \multirow{2}{*}{$\begin{array}{l}\text { População Estimada } \\
2003 \\
(01 / 07 / 03)\end{array}$} & \multirow{2}{*}{$\begin{array}{c}\text { Área }(\mathbf{k m} 2) \\
\left(\left(^{*}\right)\right.\end{array}$} & \multicolumn{4}{|c|}{ Densidade demográfica (hab/km2) } \\
\hline & & & & & & 1991 & 2000 & 2002 & 2003 \\
\hline Estado da Bahia & 11.867 .337 & 13.070 .250 & 13.323.212 & 13.435.612 & $564.692,67$ & 21,02 & 23,15 & 23,59 & 23,79 \\
\hline Metropolitana de Salvador & 2.496 .509 & 3.021.572 & 3.132.047 & 3.183.327 & 2.837 & 879,95 & $1.065,02$ & $1.103,96$ & $1.122,03$ \\
\hline Camaçari & 113.637 & 161.727 & 171.845 & 176.541 & 759,8 & 149,56 & 212,85 & 226,17 & 232,35 \\
\hline Candeias & 67.941 & 76.783 & 78.643 & 79.507 & 264,5 & 256,88 & 290,31 & 297,34 & 300,61 \\
\hline Dias D'Ávila & 31.258 & 45.333 & 48.294 & 49.668 & 207,5 & 150,64 & 218,47 & 232,74 & 239,36 \\
\hline Itaparica & 15.055 & 18.945 & 19.763 & 20.143 & 115,9 & 129,87 & 163,43 & 170,49 & 173,76 \\
\hline Lauro de Freitas & 69.268 & 113.543 & 122.858 & 127.182 & 59,9 & $1.156,30$ & 1895,38 & $2.050,88$ & $2.123,06$ \\
\hline Madre de Deus & 9.181 & 12.036 & 12.636 & 12.915 & 11,1 & 824,07 & $1.080,33$ & $1.134,19$ & $1.159,23$ \\
\hline Salvador & 2.075 .273 & 2.443 .107 & 2.520 .504 & 2.556 .429 & 706,8 & $2.936,16$ & $3.456,58$ & $3.566,08$ & $3.616,91$ \\
\hline São Francisco do Conde & 20.236 & 26.282 & 27.554 & 28.144 & 266,6 & 75,90 & 98,57 & 103,34 & 105,55 \\
\hline Simões Filho & 72.524 & 94.066 & 98.598 & 100.702 & 192,2 & 377,41 & 489,51 & 513,10 & 524,04 \\
\hline Vera Cruz & 22.136 & 29.750 & 31.352 & 32.096 & 252,8 & 87,58 & 117,70 & 124,04 & 126,98 \\
\hline
\end{tabular}

Fonte: IBGE: Censos Demográficos e Estimativas de população

(*) Área divulgada pelo IBGE, através da Resolução n 5, de 10 de outubro de 2002, publicada no DOU no 198 de 11/10/2002; Seção 1 - p. 48 - 69 
O Mapa 1 ilustra a distribuição da população residente nos municípios da região metropolitana de Salvador, de acordo com a densidade demográfica dos setores censitários em 2000. Dessa forma é possivel detalhar a presença das pessoas em espaços menores, dentro dos municípios, visíveis como um mosaico que pode representar conjuntos de bairros e seus entornos. Sem dúvida, as maiores concentrações de pessoas estão no município de Salvador, seguindo a tendência histórica de ocupação da capital. Ou seja, estão nos bairros mais tradicionais, sobretudo na orla da Baía de Todos os Santos e em todo o litoral. Nos demais municípios da RMS, os núcleos sedes das cidades são os mais densamente povoados. Em Lauro de Freitas, há concentração de pessoas nas proximidades de Salvador, já que o município tem se tornado uma extensão da ocupação da capital, onde muitos moradores circulam diariamente indo e vindo.

Por ser a capital do estado e cidade de maior dinâmica econômica, Salvador é um município que atrai pessoas migrantes do interior do estado, portanto as suas

Mapa 1 - Densidade Demográfica - Habitantes por $\mathrm{Km}^{2}$

Região Metropolitana de Salvador - 2000

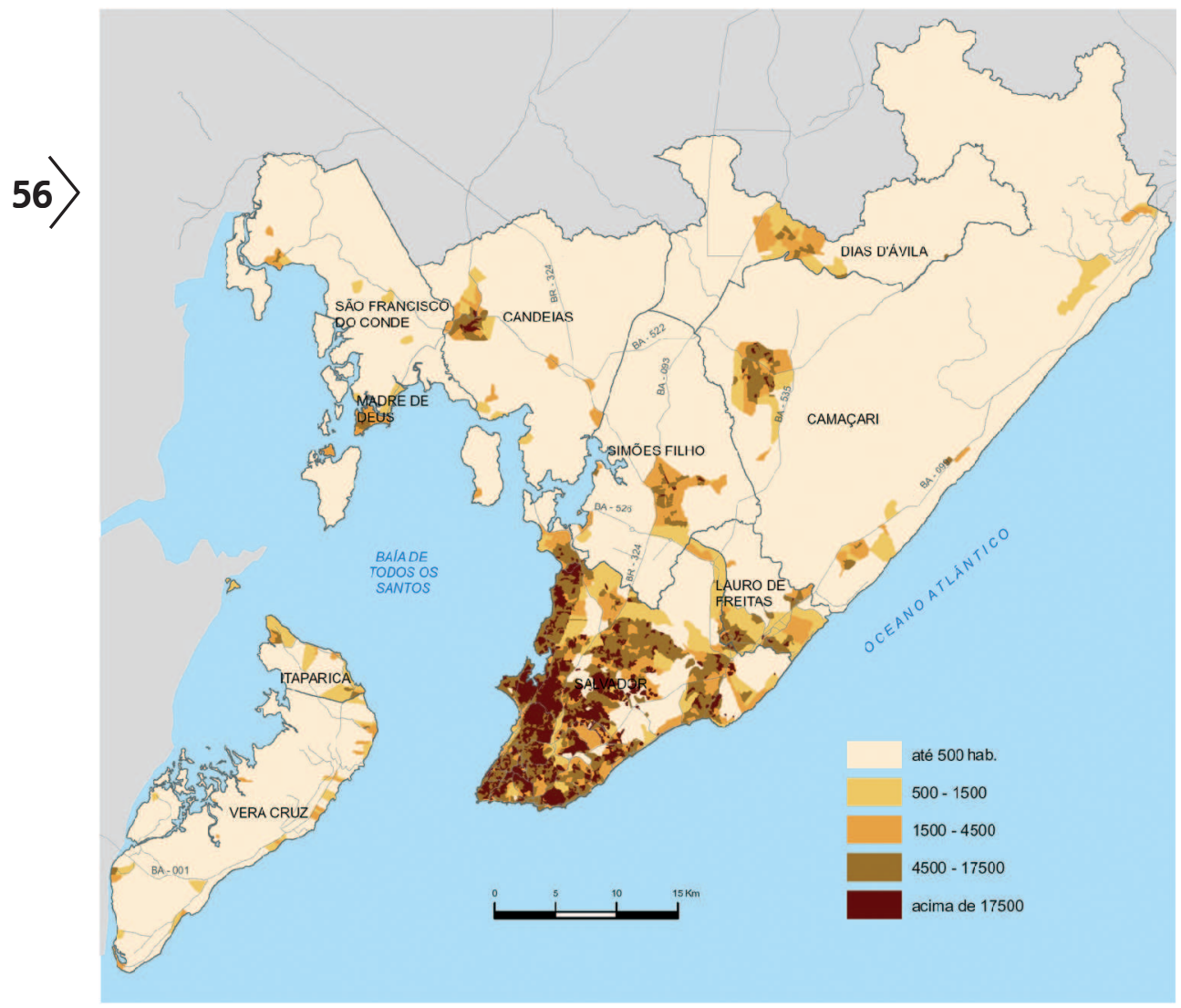

Fonte: IBGE. Censo 2000 Mapa elaborado pelos organizadores. 
áreas centrais possuem também espaços mais densamente povoados. Esses espaços muitas vezes configuram bairros com condições mais precárias de moradia, onde se estabelecem tanto os novos moradores da cidade como aqueles que não têm acesso às moradias de elevado custo, mais próximas à orla e aos locais turísticos.

O município da região metropolitana de Salvador que apresentou a maior taxa média geométrica anual de crescimento, no período intercensitário de 1991 a 2000 , foi Lauro de Freitas, com um crescimento médio de 5,7\% a.a. no período, seguido de Dias d'Ávila e Camaçari, ambos na casa dos 4\%. As taxas geométricas de crescimento de todos os municípios da RMS foram superiores à média da Bahia como um todo, que cresceu 1,1\% a.a. no período analisado.

É importante lembrar que devemos ter especial atenção quando tratamos da situação dos domicílios pesquisados nos censos demográficos brasileiros, ou seja, se eles são urbanos ou rurais. Muitas vezes, a definição de um domicílio como sendo urbano ou rural passa pela decisão do poder legislativo local, sujeita a questões políticas e administrativas. Portanto, no período intercensitário, muitos municípios sofreram mudanças puramente administrativas e passaram a ter maiores áreas urbanas, o que fez com que grande parcela de sua população residente deixasse de ser rural e passasse a ser urbana, sem qualquer deslocamento físico de pessoas.

Tabela 2 - Taxa média geométrica de crescimento anual das populações total, urbana e rural, segundo os Municípios - Bahia e Região Metropolitana de Salvador, 1991 e 2000

\begin{tabular}{l|r|r|r}
\hline \multirow{2}{*}{ Bahia, RMS e Municípios } & \multicolumn{3}{|c}{ Taxa de crescimento 1991/2000 (\% a.a.) } \\
\cline { 2 - 4 } & Total & Urbana & Rural \\
\hline Bahia & 1,09 & 2,53 & $-1,34$ \\
Metropolitana de Salvador & 2,14 & 2,31 & $-4,93$ \\
Camaçari & 4,04 & 4,03 & 3,43 \\
Candeias & 1,38 & 1,32 & 1,83 \\
Dias d'Ávila & 4,26 & 4,20 & 4,55 \\
Itaparica & 2,61 & 2,59 & 0,00 \\
Lauro de Freitas & 5,70 & 10,43 & $-16,05$ \\
Madre de Deus & 3,08 & 3,13 & 1,24 \\
Salvador & 1,85 & 1,83 & $-6,05$ \\
São Francisco do Conde & 2,97 & 3,73 & $-0,23$ \\
Simões Filho & 2,96 & 6,29 & $-5,33$ \\
Vera Cruz & 3,37 & 3,58 & 0,30 \\
\hline
\end{tabular}

Fonte: IBGE. Censos Demográficos de 1991 e 2000 
Na Região Metropolitana de Salvador, esse foi parcialmente o caso do município de Lauro de Freitas, que teve expressivas variações nas taxas médias geométricas de crescimento anual, com taxa de crescimento da população rural fortemente negativa e elevação significativa na taxa de crescimento da população urbana. Assim, essas variações devem ser vistas com cautela, considerando a influência das mudanças político-administrativas e não apenas o crescimento da população, seja ele vegetativo ou por migração. Apesar disso, o município de Lauro de Freitas tem atraído pessoas para ali residirem, em espaços tipicamente urbanos, dada uma política de vantagens fiscais em relação a Salvador para novos empreendimentos comerciais e de serviços e, também, pela proximidade física com aquela cidade, transformandose em uma área de construções de condomínios de luxo para as classes média e alta, que não teriam mais espaço na capital.

Mesmo com esse cuidado metodológico, pode-se afirmar que o grau de urbanização da Bahia e dos municípios da RMS aumentou, de 1991 para 2000. Analisando os resultados para o estado como um todo, tem-se que a Bahia era 59,0\% urbana, em 1991, e passou a ser 67,1\%, em 2000: é, portanto, ainda, um estado com expressiva parcela de sua população residindo em áreas rurais. A metrópole é fundamentalmente urbana, passando de um grau de urbanização de $96,6 \%$, em 1991, para $98,4 \%$, em 2000. Destacaram-se os aumentos nos graus de urbanização nos municípios de Lauro de Freitas, Candeias e Simões Filho. O grau de urbanização, em 2000 , era de $100 \%$ nos municípios de Salvador e Itaparica.

Em termos da participação da população residente nos municípios da RMS, em relação ao total da população residente no estado da Bahia, o município de Salvador destaca-se claramente, com $17,5 \%$ da população do estado, em 1991, passando a 18,7\%, em 2000. Já em relação ao total da população residente na área metropolitana, a participação de Salvador caiu na comparação dos dois censos: era de $83,1 \%$, em 1991, e passou a 80,9\%, em 2000. Esse pode ser um resultado do crescimento populacional - inclusive pela emigração de pessoas de Salvador - em Camaçari, Lauro de Freitas e Simões Filho, municípios da RMS que têm adotado políticas de atração de serviços e estimulado novas moradias, o que confirma o caráter de "periferização" bem próprio da região metropolitana.

\section{CARACTERÍSTICAS DA POPULAÇÃO RESIDENTE}

Analisando-se as características da população, observa-se que a distribuição da população masculina residente na Região Metropolitana de Salvador manteve-se praticamente estável, com um pequeno crescimento relativo no município de Salvador, de 1991 para 2000. O mesmo não se pode dizer da distribuição da população feminina na metrópole. Em 1991, 82,2\% das mulheres residentes na RMS estavam em Salvador; em 2000, esse percentual caiu para 80,9\%. Houve aumento relativo da presença de mulheres nos municípios de Camaçari e Lauro de Freitas, 0 
Tabela 3 - População residente por situação do domicílio e grau de urbanização, segundo os municípios Bahia e Região Metropolitana de Salvador, 1991 e 2000

\begin{tabular}{|c|c|c|c|c|c|c|c|c|}
\hline \multirow{3}{*}{ Bahia, RMS e Municípios } & \multicolumn{4}{|c|}{1991} & \multicolumn{4}{|c|}{2000} \\
\hline & \multicolumn{3}{|c|}{ População Residente } & \multirow{2}{*}{$\begin{array}{c}\text { Grau de ur- } \\
\text { banização }(\%) \\
(*)\end{array}$} & \multicolumn{3}{|c|}{ População Residente } & \multirow{2}{*}{$\begin{array}{l}\text { Grau de ur- } \\
\text { banização }(\%) \\
(*)\end{array}$} \\
\hline & Total & Urbana & Rural & & Total & Urbana & Rural & \\
\hline Bahia & 11.867.337 & 7.003 .607 & 4.863 .721 & 59,0 & 13.070 .250 & 8.772 .348 & 4.297 .902 & 67,1 \\
\hline Metropolitana de Salvador & 2.496 .509 & 2.410 .380 & 87.181 & 96,6 & 3.021 .572 & 2.973 .880 & 47.692 & 98,4 \\
\hline Camaçari & 113.637 & 108.231 & 18.444 & 95,2 & 161.727 & 154.402 & 7.325 & 95,5 \\
\hline Candeias & 67.941 & 50.563 & 5.406 & 74,4 & 76.783 & 69.127 & 7.656 & 90,0 \\
\hline Dias D'Ávila & 31.258 & 29.477 & 1.780 & 94,3 & 45.333 & 42.673 & 2.660 & 94,1 \\
\hline Itaparica & 15.055 & 15.053 & 0 & 100,0 & 18.945 & 18.945 & 0 & 100,0 \\
\hline Lauro de Freitas & 69.268 & 44.372 & 24.893 & 64,1 & 113.543 & 108.385 & 5.158 & 95,5 \\
\hline Madre de Deus & 9.181 & 8.791 & 390 & 95,8 & 12.036 & 11.599 & 437 & 96,4 \\
\hline Salvador & 2.075 .273 & 2.073 .510 & 1.762 & 99,9 & 2.443 .107 & 2.442 .102 & 1.005 & 100,0 \\
\hline São Francisco do Conde & 20.236 & 15.660 & 4.574 & 77,4 & 26.282 & 21.870 & 4.412 & 83,2 \\
\hline Simões Filho & 72.524 & 44.417 & 28.105 & 61,2 & 94.066 & 76.905 & 17.161 & 81,8 \\
\hline Vera Cruz & 22.136 & 20.306 & 1.827 & 91,7 & 29.750 & 27.872 & 1.878 & 93,7 \\
\hline
\end{tabular}

Fonte: IBGE. Censos Demográficos de 1991 e 2000

(*) População Urbana / População Total x 100 
Tabela 4 - Participação da população residente dos municípios, na população residente total da Bahia e da RMS Bahia e Região Metropolitana de Salvador, 1991 e 2000

\begin{tabular}{|c|c|c|c|c|c|c|}
\hline \multirow[b]{2}{*}{ Bahia, RMS e Municípios } & \multicolumn{3}{|c|}{1991} & \multicolumn{3}{|c|}{2000} \\
\hline & $\begin{array}{l}\text { População } \\
\text { Residente }\end{array}$ & \begin{tabular}{|c|}
$\begin{array}{c}\text { Participação na } \\
\text { população residente } \\
\text { da Bahia (\%) }\end{array}$ \\
\end{tabular} & $\begin{array}{c}\text { Participação na } \\
\text { população residente } \\
\text { da RMS (\%) }\end{array}$ & $\begin{array}{l}\text { População } \\
\text { Residente }\end{array}$ & \begin{tabular}{|c|}
$\begin{array}{c}\text { Participação na } \\
\text { população residente } \\
\text { da Bahia (\%) }\end{array}$ \\
\end{tabular} & $\begin{array}{c}\text { Participação na } \\
\text { população residente } \\
\text { da RMS (\%) } \\
\end{array}$ \\
\hline Bahia & 11.867.337 & 100,0 & - & 13.070 .250 & 100,0 & - \\
\hline Metropolitana de Salvador & 2.496 .509 & 21,0 & 100,0 & 3.021 .572 & 23,1 & 100,0 \\
\hline Camaçari & 113.637 & 1,0 & 4,6 & 161.727 & 1,2 & 5,4 \\
\hline Candeias & 67.941 & 0,6 & 2,7 & 76.783 & 0,6 & 2,5 \\
\hline Dias D'Ávila & 31.258 & 0,3 & 1,3 & 45.333 & 0,3 & 1,5 \\
\hline Itaparica & 15.05 & 0,1 & 0,6 & 18.945 & 0,1 & 0,6 \\
\hline Lauro de Freitas & 69.268 & 0,6 & 2,8 & 113.543 & 0,9 & 3,8 \\
\hline Madre de Deus & 9.181 & 0,1 & 0,4 & 12.036 & 0,1 & 0,4 \\
\hline Salvador & 2.075 .273 & 17,5 & 83,1 & 2.443 .107 & 18,7 & 80,9 \\
\hline São Francisco do Conde & 20.236 & 0,2 & 0,8 & 26.282 & 0,2 & 0,9 \\
\hline Simões Filho & 72.524 & 0,6 & 2,9 & 94.066 & 0,7 & 3,1 \\
\hline Vera Cruz & 22.136 & 0,2 & 0,9 & 29.750 & 0,2 & 1,0 \\
\hline
\end{tabular}


Tabela 5 - Distribuição da população residente por sexo, segundo os municípios Região Metropolitana de Salvador, 1991 e 20000

\begin{tabular}{l|r|r|r|r}
\hline \multirow{2}{*}{ Bahia, RMS e Municípios } & \multicolumn{2}{|c|}{1991} & \multicolumn{2}{|c}{2000} \\
\cline { 2 - 5 } & Homens & Mulheres & Homens & Mulheres \\
\cline { 2 - 4 } Metropolitana de Salvador & 100,0 & 100,0 & $\mathbf{1 0 0 , 0}$ & $\mathbf{1 0 0 , 0}$ \\
Camaçari & 4,6 & 4,8 & 4,3 & 5,4 \\
Candeias & 2,7 & 2,9 & 2,6 & 2,5 \\
Dias d'Ávila & 1,3 & 1,3 & 1,2 & 1,5 \\
Itaparica & 0,6 & 0,6 & 0,6 & 0,6 \\
Lauro de Freitas & 2,8 & 2,9 & 2,7 & 3,8 \\
Madre de Deus & 0,4 & 0,4 & 0,3 & 0,4 \\
Salvador & 83,1 & 82,2 & 83,9 & 80,9 \\
São Francisco do Conde & 0,8 & 0,9 & 0,8 & 0,9 \\
Simões Filho & 2,9 & 3,1 & 2,8 & 3,1 \\
Vera Cruz & 0,9 & 0,9 & 0,8 & 1,0 \\
\hline
\end{tabular}

que acompanha o crescimento de moradias de maior poder aquisitivo, que passaram a demandar mais intensamente serviços domésticos e auxiliares, atraindo contingentes de mulheres significativos em busca de ocupação, escassa na capital.

Já no que diz respeito à estrutura etária, as pirâmides etárias mostram a composição por idade e sexo da população residente, com a vantagem de ilustrar, entre dois períodos censitários, as mudanças entre gerações. Para o estado da Bahia em seu conjunto, têm comportamento equivalente ao da região metropolitana, com algumas distinções. Tanto o estado como a RMS apresentam uma clara redução da taxa de natalidade, evidenciada pela retração da base da pirâmide, onde estão representadas as crianças de 0 a 4 anos de idade. Os efeitos dessa redução já vêm sendo observados tanto no grupo etário de 5 a 9 anos de idade como no grupo de 10 a 14 anos. Esse processo traz conseqüências para a infra estrutura de escolas de nível fundamental, que começam a ter sobra de vagas, exigindo políticas de racionalização do uso dos equipamentos escolares. Os espaços físicos começam a ficar ociosos e, até mesmo, escolas inteiras têm sido fechadas, com o remanejamento de alunos para escolas vizinhas. Paralelamente, a geração anterior, agora jovens com até 24 anos de idade, tem estado visivelmente mais presente nas muitas faculdades particulares que se multiplicam, sobretudo em Salvador. Nas pirâmides etárias da RMS, percebe-se 0 expressivo crescimento do grupo etário de jovens de 15 a 24 anos na população, em 
2000, o que evidencia uma maior pressão por políticas públicas específicas para as pessoas desse grupo etário, tais como educação de nível médio e superior e qualificação profissional, assim como a necessidade de inclusão no mercado de trabalho desses jovens, muito mais premente do que no ano 1991.

Outro movimento demográfico importante é o claro aumento da participação de pessoas de 70 anos ou mais de idade, principalmente as mulheres, cuja sobrevivência é maior que a dos homens em espaços urbanos, que passaram dos $5 \%$ de participação na população por sexo. Não é apenas devido às conquistas políticas que se percebe a maior presença cotidiana dos idosos no dia-a-dia da cidade, mas devido à sua maior participação quantitativa na população total. São dois processos que estão diretamente relacionados e se retro-alimentam, gerando novas demandas de políticas públicas específicas.

Observando a distribuição da população por grandes grupos etários, nas Tabelas 6 e 7, essas análises são confirmadas. Para o estado da Bahia como um todo houve uma redução da participação do grupo de 0 a 14 anos de idade, de 39,7\%, em 1991, para 32,0\% da população, em 2000. O mesmo ocorre na região metropolitana: a participação do grupo de crianças cai de 34,9\%, em 1991, para 27,2\%, em 2000. Quanto à participação de pessoas idosas na população, aqui agrupadas como pessoas de 65 anos ou mais de idade, há também um crescimento relativo no período analisado, tanto na Bahia como na RMS. No entanto, observa-se que o interior do estado tem uma proporção maior de pessoas idosas que a metrópole, devido, principalmente, à emigração de jovens. Por outro lado, a RMS tem maior proporção de pessoas de 15 a 64 anos de idade - grupo que concentra majoritariamente as pessoas economicamente ativas ocupadas ou dispostas a trabalhar - que a média do estado, já que atrai pessoas nessa faixa etária em busca de ocupações.

Dentre os municípios da RMS, Salvador tem a menor proporção de crianças de 0 a 14 anos de idade em sua população residente, tanto em 1991 como em 2000, o que pode ser explicado de duas formas basicamente. 0 município apresenta menores taxas de natalidade e, ao mesmo tempo, é um pólo de atração de adultos jovens, o que ajuda a explicar, mais uma vez, a maior proporção de pessoas de 15 a 64 anos de idade.

Isso fica claro quando observamos o mapa da distribuição das crianças de 0 a 14 anos de idade nos setores censitários dos municípios da RMS. As maiores proporções de crianças estão nas áreas menos densamente povoadas da metrópole, mais distantes do litoral. Nos municípios de Camaçari, Simões Filho e Dias D’Ávila, os setores censitários possuem proporções acima dos $33 \%$ de crianças até 14 anos de idade. Em Camaçari, nos setores localizados no entorno do Pólo Petroquímico, estão as menores proporções de crianças na população, devido ao perfil menos residencial desse espaço. E, em Salvador, estão os setores com menores proporções de crianças, sobretudo na área do farol da Barra até o Centro Histórico da cidade.

Já as pessoas adultas, na faixa de 15 a 64 anos de idade, consideradas aquelas mais atuantes como população economicamente ativa, estão presentes nos espaços da metrópole onde as atividades econômicas são mais dinâmicas, assim 
Gráfico 1 - Pirâmides Etárias - Bahia e Região Metropolitana de Salvador, 1991 e 2000
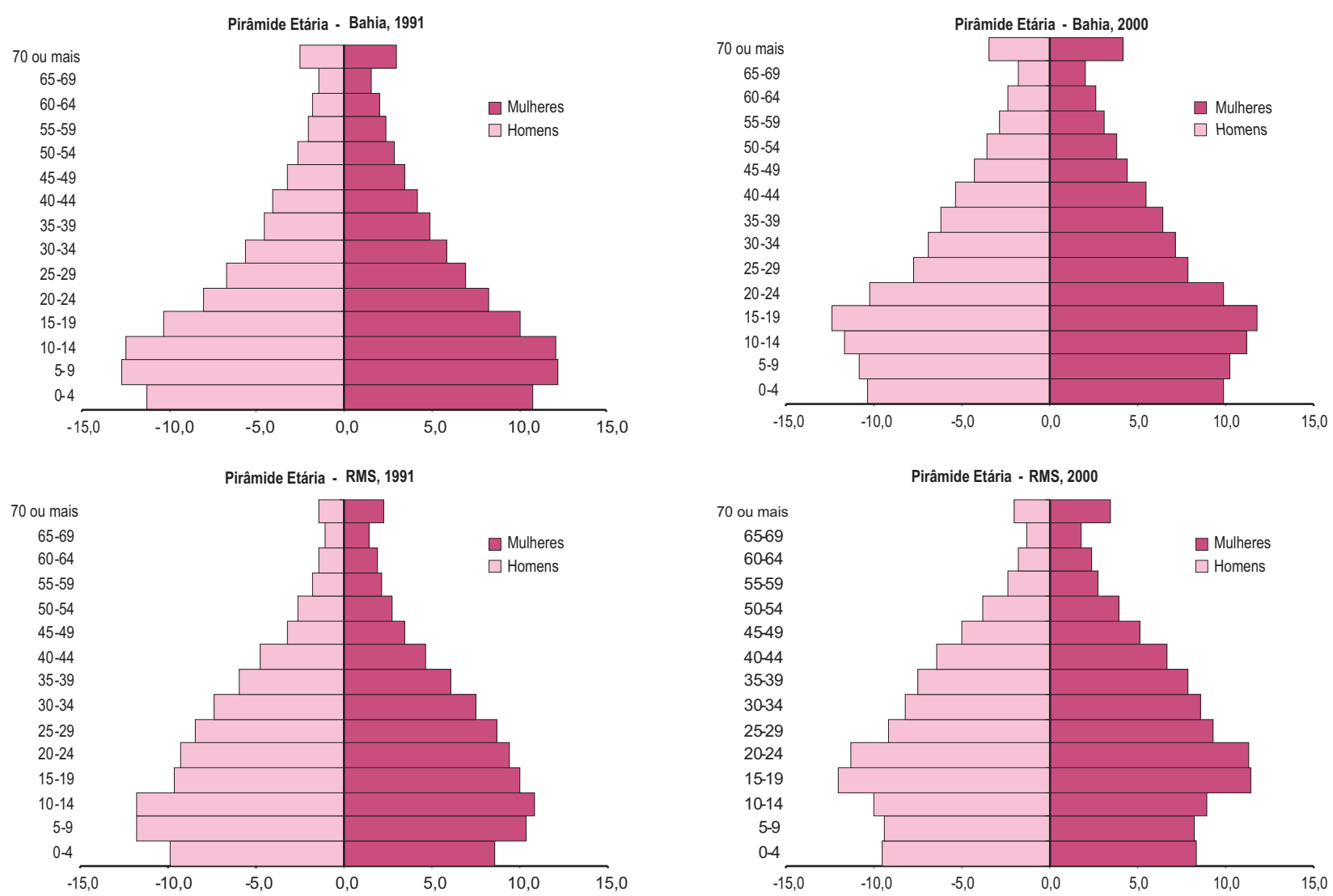
Tabela 6 - População residente, por grandes grupos de idade, segundo os municípios Bahia e Região Metropolitana de Salvador, 1991

\begin{tabular}{|c|c|c|c|c|c|c|c|}
\hline \multirow{3}{*}{$\begin{array}{l}\text { Bahia, RMS e } \\
\text { Municípios }\end{array}$} & \multirow{3}{*}{$\begin{array}{c}\text { População } \\
\text { Total* }\end{array}$} & \multicolumn{6}{|c|}{ Grandes grupos etários } \\
\hline & & \multicolumn{2}{|c|}{0 a 14 anos } & \multicolumn{2}{|c|}{15 a 64 anos } & \multicolumn{2}{|c|}{65 anos e mais } \\
\hline & & Abs. & $\%$ & Abs. & $\%$ & Abs. & $\%$ \\
\hline Bahia & 11.867.337 & 4.713 .708 & 39,72 & 6.587 .408 & 55,51 & 566.208 & 4,77 \\
\hline RMS & 2.496 .509 & 871.545 & 34,91 & 1.540 .259 & 61,70 & 84.553 & 3,39 \\
\hline Camaçari & 113.637 & 47.446 & 41,75 & 63.970 & 56,29 & 2.207 & 1,94 \\
\hline Candeias & 67.941 & 27.200 & 40,03 & 38.956 & 57,34 & 1.770 & 2,61 \\
\hline Dias d'Ávila & 31.258 & 13.102 & 41,92 & 17.499 & 55,98 & 640 & 2,05 \\
\hline Itaparica & 15.055 & 6.021 & 39,99 & 8.326 & 55,30 & 695 & 4,62 \\
\hline Lauro de Freitas & 69.268 & 28.034 & 40,47 & 39.662 & 57,26 & 1.556 & 2,25 \\
\hline Madre de Deus & 9.181 & 3.283 & 35,76 & 5.534 & 60,28 & 346 & 3,77 \\
\hline Salvador & 2.075 .273 & 699.172 & 33,69 & 1.302 .156 & 62,75 & 73.931 & 3,56 \\
\hline S. Francisco do Conde & 20.236 & 8.455 & 41,78 & 10.997 & 54,34 & 767 & 3,79 \\
\hline Simões Filho & 72.524 & 30.192 & 41,63 & 40.610 & 56,00 & 1.706 & 2,35 \\
\hline Vera Cruz & 22.136 & 8.640 & 39,03 & 12.549 & 56,69 & 935 & 4,22 \\
\hline
\end{tabular}

Fonte: IBGE. Censo Demográfico de 1991.

* Inclusive as pessoas com idade ignorada

Tabela 7 - População residente, por grandes grupos de idade, segundo os municípios Bahia e Região Metropolitana de Salvador, 2000

\begin{tabular}{|c|c|c|c|c|c|c|c|}
\hline \multirow{3}{*}{$\begin{array}{l}\text { Bahia, RMS e } \\
\text { Municípios }\end{array}$} & \multirow{3}{*}{$\begin{array}{c}\text { População } \\
\text { Total }\end{array}$} & \multicolumn{6}{|c|}{ Grandes grupos etários } \\
\hline & & \multicolumn{2}{|c|}{0 a 14 anos } & \multicolumn{2}{|c|}{15 a 64 anos } & \multicolumn{2}{|c|}{65 anos e mais } \\
\hline & & Abs. & $\%$ & Abs. & $\%$ & Abs. & $\%$ \\
\hline Bahia & 13.070 .250 & 4.186 .827 & 32,03 & 8.132 .948 & 62,22 & 750.475 & 5,74 \\
\hline RMS & 3.021 .572 & 822.121 & 27,21 & 2.069 .795 & 68,50 & 129.655 & 4,29 \\
\hline Camaçari & 161.727 & 52.137 & 32,24 & 105.331 & 65,13 & 4.258 & 2,63 \\
\hline Candeias & 76.783 & 23.395 & 30,47 & 50.740 & 66,08 & 2.648 & 3,45 \\
\hline Dias d'Ávila & 45.333 & 15.197 & 33,52 & 28.818 & 63,57 & 1.318 & 2,91 \\
\hline Itaparica & 18.945 & 5.900 & 31,15 & 11.993 & 63,30 & 1.052 & 5,55 \\
\hline Lauro de Freitas & 113.543 & 34.527 & 30,41 & 75.523 & 66,52 & 3.493 & 3,08 \\
\hline Madre de Deus & 12.036 & 3.479 & 28,90 & 8.105 & 67,34 & 451 & 3,75 \\
\hline Salvador & 2.443 .107 & 638.479 & 26,13 & 1.693 .426 & 69,31 & 111.202 & 4,55 \\
\hline S. Francisco do Conde & 26.282 & 8.547 & 32,52 & 16.746 & 63,72 & 990 & 3,77 \\
\hline Simões Filho & 94.066 & 31.073 & 33,03 & 60.298 & 64,10 & 2.695 & 2,87 \\
\hline Vera Cruz & 29.750 & 9.386 & 31,55 & 18.815 & 63,24 & 1.549 & 5,21 \\
\hline
\end{tabular}

Fonte: IBGE. Censo Demográfico de 1991 
Mapa 2 - Distribuição percentual das pessoas de 0 a 14 anos de idade Região Metropolitana de Salvador - 2000

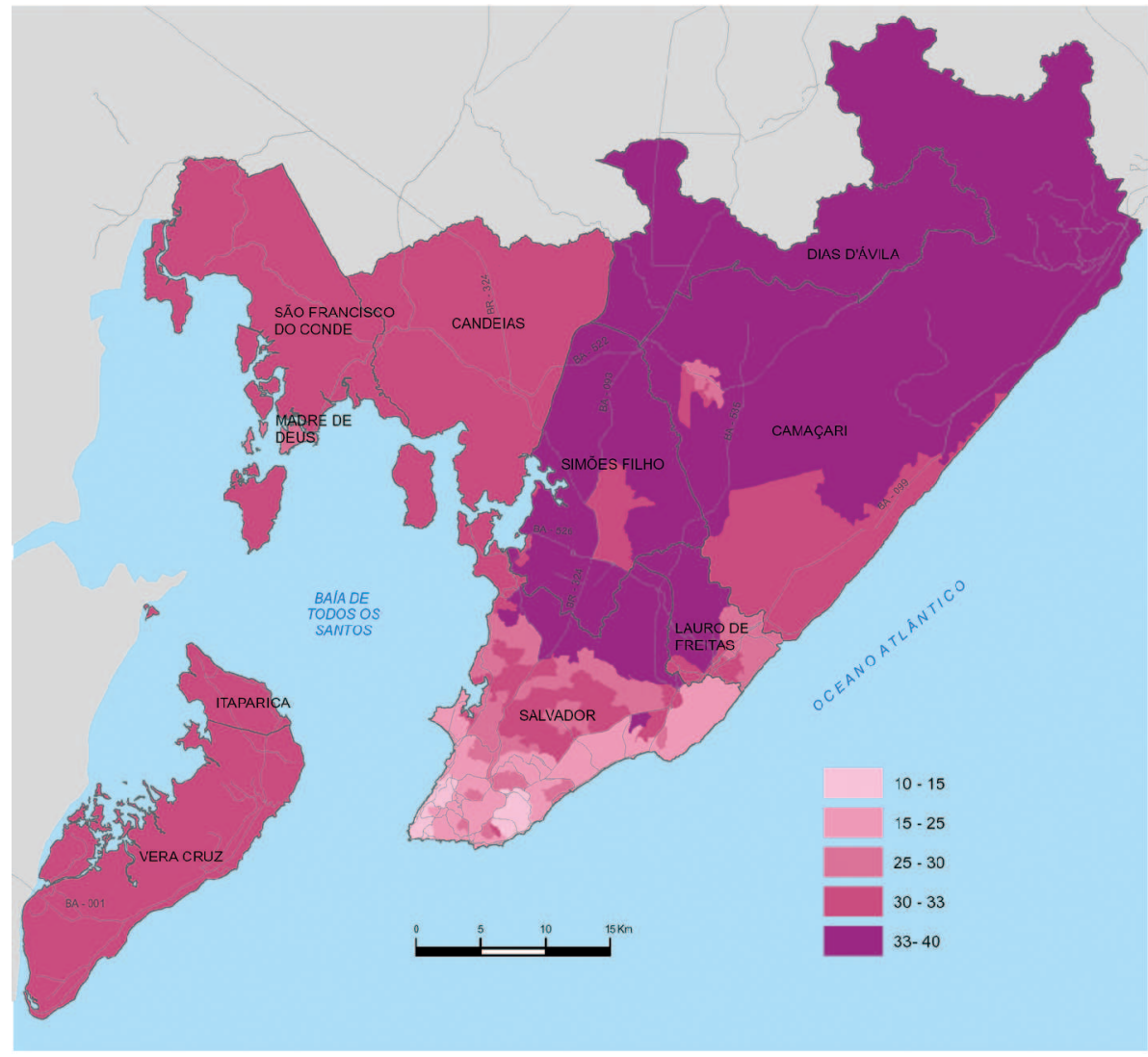

Fonte: IBGE. Censo 2000. Mapa elaborado pelos organizadores.

como a vida cultural. As pessoas desse grupo etário estão, em geral, ocupadas ou dispostas a trabalhar e, portanto, tendem a morar em bairros onde as oportunidades de trabalho são mais abundantes, de forma a facilitar sua inserção e permanência no mercado de trabalho. De acordo com o mapa de setores censitários, as maiores proporções de pessoas de 15 a 64 anos de idade estão no município de Salvador, sobretudo próximas aos bairros da Barra, Ondina, Pituba e Pituaçu. Nos demais municípios da metrópole, estão nas proximidades do Pólo Petroquímico em Camaçari, no litoral de Lauro de Freitas e nas sedes de Candeias, Madre de Deus (a quantidade de setores censitários nesses municípios é bem menor que nos anteriores, o que não permite maior detalhamento) e Simões Filho.

Por fim, a proporção de pessoas idosas cresceu em todos os municípios da região metropolitana de Salvador, sendo que os municípios com maiores participações de pessoas idosas eram Itaparica e Vera Cruz. O envelhecimento da 
Mapa 3 - Distribuição percentual das pessoas de 15 a 64 anos de idade

Região Metropolitana de Salvador - 2000

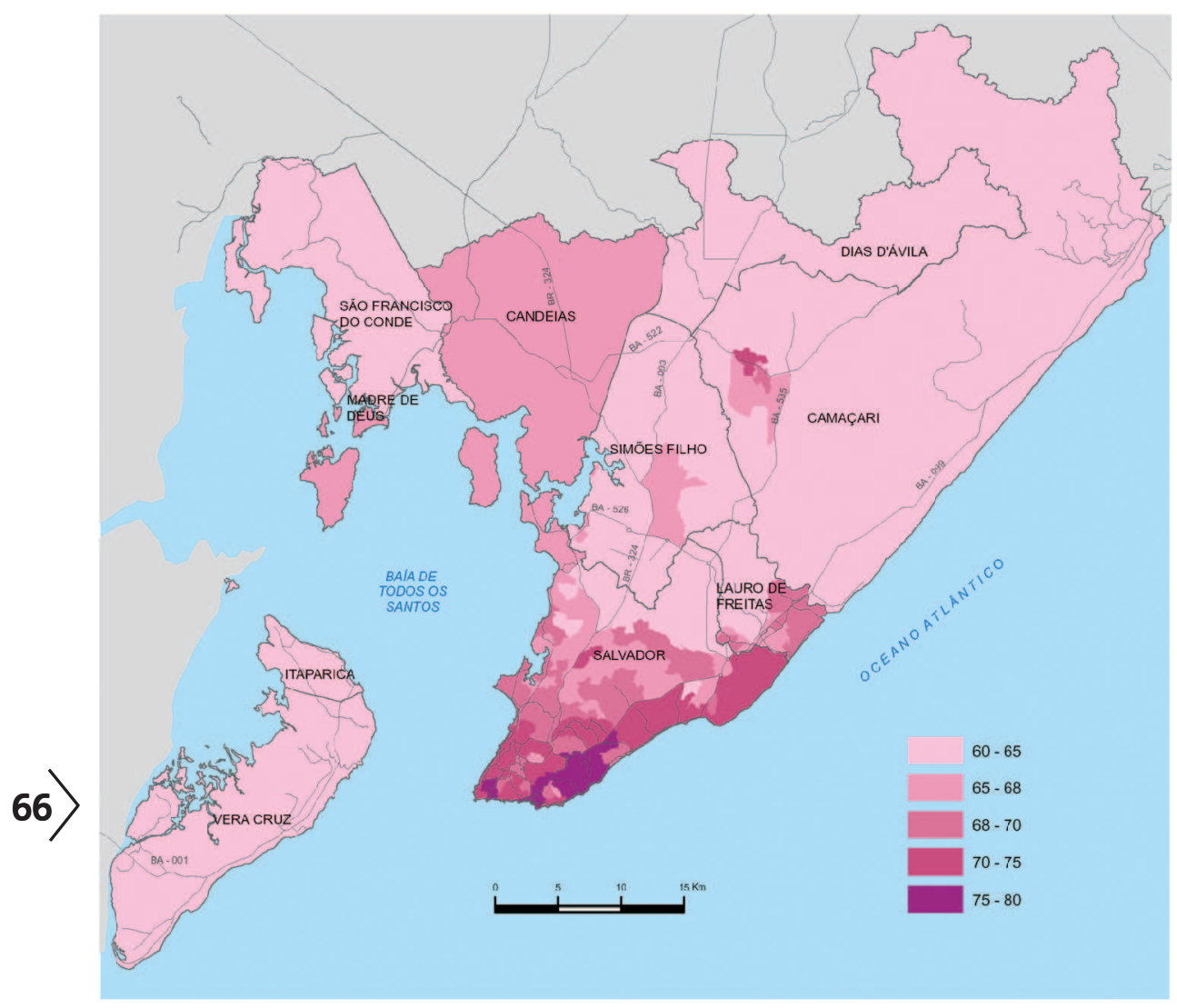

Fonte: IBGE. Censo 2000. Mapa elaborado pelos organizadores.

população é um fenômeno demográfico mais abrangente, que está relacionado com a melhoria, mesmo que gradual e ainda restrita, nas condições de vida e moradia (saneamento, acesso à água e coleta de lixo) e nas condições de saúde.

Os espaços em que há maior presença de pessoas idosas na região metropolitana concentram-se nos bairros mais tradicionais de Salvador, sobretudo na orla da Baía de Todos os Santos, em bairros como Barra, Campo Grande, Bonfim e em áreas nobres como Caminho das Árvores e Itaigara. Fora de Salvador, existem proporções relativamente elevadas de pessoas idosas em Itaparica, Madre de Deus, São Francisco do Conde e no Litoral Norte de Camaçari. As pessoas com 65 anos de idade ou mais já ocupavam essas áreas há mais tempo e, portanto, tiveram acesso à moradia antes da valorização imobiliária mais recente nas áreas nobres. Além disso, após saírem do mercado de trabalho, muitas pessoas buscam moradias em áreas mais afastadas dos centros comerciais e com melhor qualidade de vida, como é o caso de Itaparica e do Litoral Norte. 


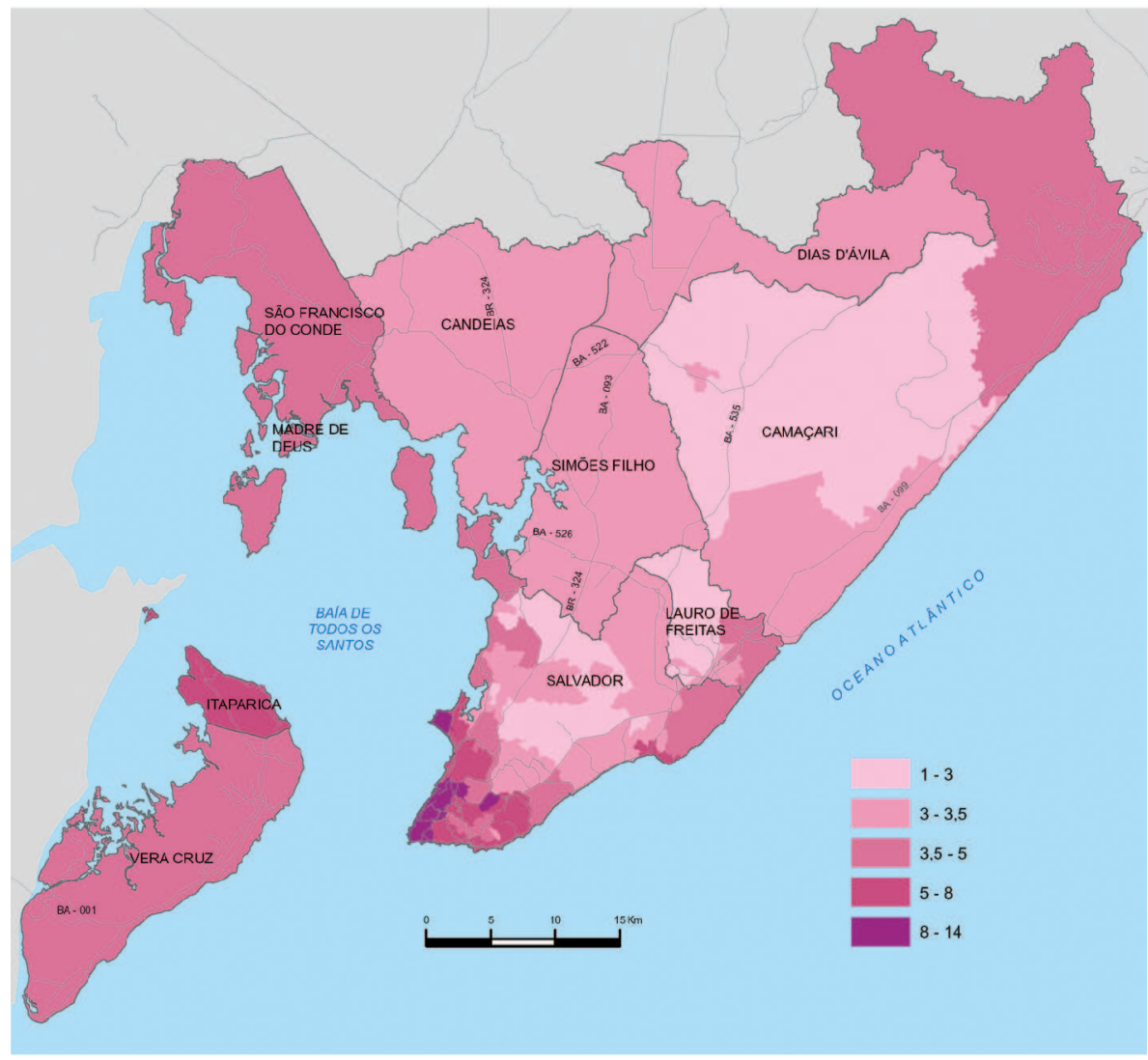

Fonte: IBGE. Censo 2000. Mapa elaborado pelos organizadores.

\section{CARACTERÍSTICAS DAS FAMÍLIAS}

O número de famílias identificado pelos levantamentos censitários, na Bahia, passou de 2,7 milhões, em 1991, para 3,5 milhões de familias, em 2000, sendo que 877 mil famílias residiam na região metropolitana de Salvador no último censo. A proporção de mulheres responsáveis por famílias teve expressivo crescimento entre os períodos analisados: no estado da Bahia, passou de 22,4\% para 29,3\%, de 1991 a 2000, e, na região metropolitana, o aumento foi ainda mais significativo, de 27,9\% (proporção já elevada) para 38,1\%. Os municípios da RMS que possuíam as maiores proporções de famílias sob responsabilidade de mulheres eram Salvador, São Francisco do Conde e Itaparica.

Levando em conta as maiores dificuldades de inserção no mercado de trabalho das mulheres, em condições equivalentes às masculinas, principalmente 
recebendo menores salários, estudos mostram ${ }^{2}$ que famílias sob responsabilidade de mulheres são mais vulneráveis a dificuldades no seu provimento financeiro. De acordo com Guimarães (2003), "as famílias sob responsabilidade feminina costumam ter menos adultos e mais crianças. Salvo exceções, as mulheres chefes de família são divorciadas, viúvas ou solteiras. Com efeito, segundo as informações da PNAD de 1999 , apenas $3,3 \%$ das pessoas que se declararam cônjuges estão em famílias cuja chefia é feminina."

A maior presença de famílias sob responsabilidade de mulheres pode também estar relacionada com as elevadas taxas de desemprego na região metropolitana de Salvador ou, ainda, à emigração de mão-de-obra masculina para outros estados, o que pode ser melhor investigado. Mais ainda: observam-se claras desigualdades na inserção no mercado de trabalho relacionadas a gênero, o que faz com que as famílias sob a responsabilidade de mulheres apresentem um maior grau de vulnerabilidade à pobreza. Ainda segundo Guimarães (2003), "o mais elevado nível de desemprego, o menor número de horas trabalhadas em virtude das responsabilidades domésticas, os salários mais baixos, as maiores dificuldades para ingressar no mercado de trabalho e 0 acesso mais restrito aos recursos produtivos diferenciam substancialmente as mulheres responsáveis pelas famílias".

Tabela 8 -Pessoas responsáveis pelas famílias por sexo, segundo os municípios Bahia e Região Metropolitana de Salvador, 1991 e 2000

\begin{tabular}{|c|c|c|c|c|c|c|c|c|}
\hline \multirow[t]{2}{*}{$\begin{array}{l}\text { Bahia, RMS e } \\
\text { Municípios }\end{array}$} & \multicolumn{3}{|c|}{1991} & \multicolumn{3}{|c|}{2000} & \multicolumn{2}{|c|}{$\begin{array}{l}\text { Proporção de } \\
\text { mulheres } \\
\text { responsáveis por } \\
\text { famílias (\%) }\end{array}$} \\
\hline & Total & Homens & Mulheres & Total & Homens & Mulheres & 1991 & 2000 \\
\hline Bahia & 2.710 .630 & 2.103.140 & 607.490 & 3.493.512 & 2.471 .426 & 1.022 .086 & 22,4 & 29,3 \\
\hline RMS & 622.182 & 448.693 & 173.489 & 878.147 & 543.977 & 334.170 & 27,9 & 38,1 \\
\hline Camaçari & 26.666 & 21.584 & 5.082 & 44.798 & 32.024 & 12.774 & 19,1 & 28,5 \\
\hline Candeias & 15.456 & 11.914 & 3.542 & 21.001 & 14.443 & 6.558 & 22,9 & 31,2 \\
\hline Dias d'Ávila & 7.479 & 6.017 & 1.462 & 12.475 & 8.818 & 3.657 & 19,5 & 29,3 \\
\hline Itaparica & 3.536 & 2.459 & 1.077 & 5.521 & 3.410 & 2.111 & 30,5 & 38,2 \\
\hline Lauro de Freitas & 16.768 & 13.060 & 3.708 & 31.857 & 21.708 & 10.149 & 22,1 & 31,9 \\
\hline Madre de Deus & 2.123 & 1.676 & 447 & 3.430 & 2.232 & 1.198 & 21,1 & 34,9 \\
\hline Salvador & 523.641 & 371.075 & 152.566 & 718.283 & 434.160 & 284.123 & 29,1 & 39,6 \\
\hline S. Francisco do Conde & 4.569 & 3.323 & 1.246 & 7.075 & 4.284 & 2.791 & 27,3 & 39,4 \\
\hline Simões Filho & 16.423 & 13.351 & 3.072 & 25.394 & 17.062 & 8.332 & 18,7 & 32,8 \\
\hline Vera Cruz & 5.521 & 4.234 & 1.287 & 8.313 & 5.836 & 2.477 & 23,3 & 29,8 \\
\hline
\end{tabular}

Fonte: IBGE. Censos Demográficos de 1991 e 2000

${ }^{2}$ Como os de Guimarães (2003) e Carvalho (2003), por exemplo. 
A partir do Censo 2000, foram levantadas algumas formas de arranjos familiares para a Bahia e a região metropolitana de Salvador. Para o estado da Bahia, como um todo, a proporção de casais com filhos é superior à da região metropolitana, enquanto que as mães com filhos são mais freqüentes nessa área. Famílias do tipo "casal sem filhos" são relativamente mais comuns no município de Vera Cruz (12,0\%, contra um padrão em torno de $9 \%$ nas demais áreas). O município de Salvador tem a menor proporção de casais com filhos, forma mais tradicional. É importante lembrar que o tipo "outros" engloba pessoas que vivem sós.

Volta aqui a questão das famílias sob a responsabilidade feminina, com a presença importante de famílias de "mães com filhos", sem cônjuge, relativamente maior que 0 arranjo tradicional "casal com filhos", seja no estado como um todo, na região metropolitana ou em quaisquer dos municípios que a compõem. $O$ exercício do papel de provedor da família deixa de ser complementar, dividido entre o casal, e passa a ser único, em condições desiguais e de menores rendimentos para as mulheres.

Como assinala Carvalho (2003),

o declínio do poder patriarcal e de princípios e controles religiosos e mais tradicionais traduziu-se em mudanças nas relações de gênero, na ampliação da autonomia dos diversos componentes da família e em um exercício bem mais aberto e livre da sexualidade, dissociada das responsabilidades da reprodução. A presença de mulheres no mercado de trabalho passou a ser

Tabela 9 - Famílias e sua distribuição por tipo, segundo os municípios Bahia e Região Metropolitana de Salvador, 2000

\begin{tabular}{|c|c|c|c|c|c|c|c|}
\hline \multirow{2}{*}{$\begin{array}{c}\text { Bahia, RMS e } \\
\text { Municípios }\end{array}$} & \multirow[b]{2}{*}{ Famílias } & \multicolumn{6}{|c|}{ Distribuição das famílias por tipo (\%) } \\
\hline & & Total & $\begin{array}{l}\text { Casal } \\
\text { sem } \\
\text { filhos }\end{array}$ & $\begin{array}{l}\text { Casal } \\
\text { com } \\
\text { filhos }\end{array}$ & $\begin{array}{l}\text { Mãe } \\
\text { com } \\
\text { filhos }\end{array}$ & $\begin{array}{l}\text { Pai com } \\
\text { filhos }\end{array}$ & Outros \\
\hline Bahia & 3.489.227 & 100,0 & 9,4 & 46,1 & 13,7 & 1,9 & 28,8 \\
\hline RMS & 877.268 & 100,0 & 9,2 & 40,6 & 17,1 & 2,1 & 31,1 \\
\hline Camaçari & 44.766 & 100,0 & 9,0 & 45,9 & 14,0 & 1,9 & 29,2 \\
\hline Candeias & 21.002 & 100,0 & 9,0 & 46,7 & 16,6 & 2,3 & 25,4 \\
\hline Dias d'Ávila & 12.476 & 100,0 & 8,3 & 46,4 & 14,8 & 2,1 & 28,5 \\
\hline Itaparica & 5.515 & 100,0 & 8,7 & 39,9 & 18,5 & 2,2 & 30,7 \\
\hline Lauro de Freitas & 31.802 & 100,0 & 9,3 & 44,8 & 13,6 & 2,1 & 30,2 \\
\hline Madre de Deus & 3.424 & 100,0 & 9,0 & 47,1 & 19,8 & 1,7 & 22,4 \\
\hline Salvador & 717.538 & 100,0 & 9,2 & 39,6 & 17,5 & 2,1 & 31,7 \\
\hline S. Francisco do Conde & 7.069 & 100,0 & 7,8 & 43,1 & 19,4 & 2,7 & 27,0 \\
\hline Simões Filho & 25.368 & 100,0 & 9,1 & 47,0 & 16,0 & 2,0 & 25,9 \\
\hline Vera Cruz & 8.308 & 100,0 & 12,0 & 39,0 & 14,4 & 2,6 & 32,0 \\
\hline
\end{tabular}

Fonte: IBGE. Censo Demográfico 2000 
crescente, assim como a difusão e utilização de práticas anticoncepcionais e a fragilização dos laços matrimoniais, com o aumento das separações, dos divórcios e de novos acordos sexuais.

O aumento significativo das famílias sob responsabilidade de mulheres, tanto por questões demográficas como socioeconômicas - relacionado às condições de inserção ocupacional das mulheres - tem implicações importantes para a vulnerabilidade social dessas famílias, assim como nas características da pobreza da RMS.

\section{CONDIÇÕES DE SOBREVIVÊNCIA E MORTALIDADE}

Alguns indicadores demográficos sinalizam como estão as condições de saúde e sobrevivência das pessoas residentes: os principais são a esperança de vida ao nascer e a taxa de mortalidade infantil, indicadores muito utilizados como uma aproximação das condições de bem-estar e atendimento em saúde em determinados lugares.

O indicador de esperança de vida ao nascer, que dá a expectativa de sobrevivência, em anos, das pessoas nascidas em determinado período, melhorou tanto para o estado da Bahia como para os municípios metropolitanos, de 1991 para 2000. No conjunto do estado da Bahia, a esperança de vida ao nascer passou de

Tabela 10 - Esperança de vida ao nascer, segundo os municípios por Região Econômica Bahia e Região Metropolitana de Salvador, 1991 e 2000

\begin{tabular}{l|c|c}
\hline \multirow{2}{*}{\multicolumn{1}{c|}{ Bahia, RMS e Municípios }} & \multicolumn{2}{|c}{ Esperança de vida ao nascer (em anos) (*) } \\
\cline { 2 - 3 } Bahia & 1991 & $\mathbf{2 0 0 0}$ \\
Camaçari & 59,94 & 64,63 \\
Candeias & 60,18 & 67,44 \\
Dias d'Ávila & 58,49 & 66,06 \\
Itaparica & 60,47 & 67,93 \\
Lauro de Freitas & 61,06 & 66,34 \\
Madre de Deus & 61,51 & 66,62 \\
Salvador & 61,76 & 67,44 \\
São Francisco do Conde & 65,73 & 69,64 \\
Simões Filho & 60,59 & 66,34 \\
Vera Cruz & 63,13 & 66,62 \\
\hline
\end{tabular}

Fonte: IBGE. Censos Demográficos de 1991 e 2000 
59,9 anos, em 1991, para 64,6 anos, em 2000. Nos municípios da RMS, esse indicador ficou mais próximo dos 70 anos, sendo que a maior esperança de vida ao nascer é a de Salvador, com 69,6 anos.

A taxa de mortalidade infantil, que mede o número de óbitos de crianças com menos de um ano de idade, em relação a cada mil crianças nascidas vivas, foi um dos indicadores que teve maior queda nos últimos anos, por ser muito sensível à aplicação de medidas simples de higiene e saneamento básico, como cuidados relativos ao atendimento pré-natal às gestantes, condições no momento do parto e atendimento médico pós-parto e assistência ao recém-nascido. Quando em patamares muito elevados, as quedas nas taxas de mortalidade infantil são rápidas e expressivas; mas são mais difíceis de reduzir quando em patamares mais baixos, exigindo ações de saúde mais estruturadas. Esse processo vem acontecendo em todo o Nordeste brasileiro.

No estado da Bahia, a taxa média de mortalidade infantil caiu, de elevados $70,9 \%$, em 1991, para 46,5\%, em 2000. É ainda uma taxa muito elevada, mas que deve cair a um ritmo bem mais lento daqui por diante. Em todos os municípios da RMS, as taxas de mortalidade infantil eram mais baixas que a média estadual. $O$ município com menor taxa, em 2000, era Dias d'Ávila, seguido por Salvador e Camaçari.

A título de ilustração, e para ter uma complementação às informações de mortalidade infantil, vale considerar outras causas de morte das pessoas residentes na Bahia e na RMS, para o ano de 2001, com base em informações do sistema de banco de dados do Ministério da Saúde - o DataSUS. Essas informações devem ser analisadas com especial cuidado, devido ao elevado grau de sub-registro, comum no Nordeste, o que "infla" grupos de causas "não classificadas".

Para a Região Metropolitana de Salvador, onde os registros têm melhor qualidade que no interior do estado, percebe-se uma maior frequêencia de óbitos causados por doenças do aparelho circulatório e respiratório, consideradas mais comuns na vida urbana - respectivamente $28,1 \%$ e $10,4 \%$ do total de óbitos registrados. Outro destaque está nas causas externas de morbidade e de mortalidade, que englobam mortes no trânsito ou violentas, representando $13 \%$ dos óbitos registrados na RMS.

\section{FECUNDIDADE E MIGRAÇÃO}

Para avaliar as condições de fecundidade das mulheres residentes na região metropolitana de Salvador foram gerados indicadores para dois grupos etários distintos: primeiro, para todas as mulheres de 10 anos ou mais de idade e, em seguida, para as mulheres de 15 a 49 anos de idade. 0 primeiro grupo traz o conjunto de informações disponíveis sobre fecundidade no Censo, mas tem um viés de redução da taxa de fecundidade, por incluir as crianças de 10 a 14 anos, e, ao mesmo tempo, de ampliação da taxa de fecundidade, por carregar as elevadas fecundidades das mulheres de mais idade, acima dos 50 anos, que vieram de gerações anteriores àquelas das 
mulheres hoje em idade reprodutiva.

As análises demográficas, em geral, centram os indicadores de fecundidade nas mulheres consideradas em idade reprodutiva, grupo convencionado entre as idades de 15 até 49 anos.

No caso do conjunto de mulheres de 10 anos ou mais, percebeu-se uma taxa de fecundidade de 2,41 filhos tidos nascidos vivos (FTNV) por mulher, no estado da Bahia, em 2000, e 1,79 na RMS como um todo. Salvador era o município da RMS com a menor taxa de fecundidade (1,72 FTNV/mulher), com grande peso na média da região. Todos os demais municípios da região metropolitana tinham taxas abaixo da média do estado.

Considerando as mulheres em idade reprodutiva - de 15 a 49 anos - as taxas de fecundidade caem e, a média do estado da Bahia, fica em 1,87 FTNV/mulher. Nesse grupo, observa-se que, das mulheres que tiveram filhos nascidos vivos, as proporções daquelas com até 2 filhos são sempre superiores a $50 \%$, tanto na Bahia como na RMS em seu conjunto e nos municípios estudados. Salvador mantém-se como município com a mais baixa taxa de fecundidade (1,36 FTNV/mulher) e também com a menor proporção de mulheres de 15 a 49 anos com 5 filhos ou mais. Aqui, os municípios de São Francisco do Conde e Dias d'Ávila apresentaram taxas um pouco superiores à média estadual.

Em relação aos movimentos migratórios, a região metropolitana de Salvador, em seu conjunto, éatrativa de pessoas e apresentou um saldo migratório total (emigrantes menos imigrantes) de 30.150 pessoas, entre 1995 e 2000 . Existem diferenças importantes entre os municípios da RMS no que diz respeito ao saldo migratório.

Dos dez municípios da RMS, oito possuem saldo positivo, com destaque para Lauro de Freitas, que recebeu 20.152 pessoas, principalmente do próprio estado da Bahia; mas Lauro de Freitas também é o município da região que recebeu maior número de pessoas de fora do estado. Vale relembrar que o município vem atraindo pessoas de maior poder aquisitivo que deixaram Salvador para condomínios de classes média e alta e, também, empresas de serviços com incentivos municipais. Em seguida vem Camaçari, com saldo positivo de 14.003 pessoas, que vieram para o município que detém o Pólo Petroquímico.

Salvador e Candeias possuem saldos migratórios negativos e as pessoas que emigram de Salvador vão principalmente para fora do estado da Bahia.

É interessante analisar de quais regiões do Brasil vêm imigrantes para a região metropolitana de Salvador. Para Lauro de Freitas, migram pessoas da região Sudeste do país ( $50,3 \%$ dos seus imigrantes) e os que vêm para Salvador também são oriundos principalmente do Sudeste $(50,7 \%)$.

Finalmente, o principal destino dos emigrantes da RMS, seja de qual for o município analisado, é claramente a Região Sudeste do país, que recebe $62,8 \%$ dos emigrantes interestaduais da região. É para lá que continuam indo sobretudo pessoas em idade ativa, majoritariamente homens, em busca de melhores oportunidades de ocupação. 
Tabela 11 - Óbitos por grupos de causas, segundo os municípios de residência por Região Econômica Bahia e Região Metropolitana de Salvador, 2001

\begin{tabular}{|c|c|c|c|c|c|c|c|c|c|}
\hline \multirow[b]{2}{*}{$\begin{array}{c}\text { Bahia, RMS e } \\
\text { Municípios }\end{array}$} & \multicolumn{9}{|c|}{ Grupos de Causas (\%) } \\
\hline & $\begin{array}{c}\text { Total de } \\
\text { óbitos }\end{array}$ & $\begin{array}{c}\text { Algumas } \\
\text { doenças } \\
\text { infecciosas e } \\
\text { parasitárias }\end{array}$ & $\begin{array}{l}\text { Neoplasias } \\
\text { [Tumores] }\end{array}$ & $\begin{array}{c}\text { Doenças do } \\
\text { aparelho } \\
\text { circulatório }\end{array}$ & $\begin{array}{c}\text { Doenças do } \\
\text { aparelho } \\
\text { respiratório }\end{array}$ & $\begin{array}{c}\text { Algumas } \\
\text { afecções } \\
\text { originadas } \\
\text { no período } \\
\text { perinatal }\end{array}$ & $\begin{array}{c}\text { Sintomas, sinais } \\
\text { e achados } \\
\text { anormais de } \\
\text { exames clínicos } \\
\text { e de } \\
\text { laboratório, não } \\
\text { classificados } \\
\text { em outra parte }\end{array}$ & $\begin{array}{c}\text { Causas } \\
\text { externas } \\
\text { de morbidade } \\
\text { e de } \\
\text { mortalidade }\end{array}$ & $\begin{array}{l}\text { Demais } \\
\text { causas }\end{array}$ \\
\hline Bahia & 60.785 & 5,2 & 8,4 & 22,5 & 7,1 & 5,3 & 26,7 & 10,7 & 14,1 \\
\hline RMS & 15.706 & 6,7 & 13,5 & 28,1 & 10,4 & 7,1 & 3,3 & 13,0 & 18,0 \\
\hline Camaçari & 635 & 4,7 & 10,9 & 25,5 & 8,5 & 9,4 & 3,6 & 18,4 & 18,9 \\
\hline Candeias & 294 & 4,8 & 10,2 & 26,5 & 10,2 & 3,1 & 13,6 & 11,6 & 20,1 \\
\hline Dias d'Ávila & 208 & 8,2 & 11,5 & 26,4 & 9,1 & 7,7 & 2,9 & 15,9 & 18,3 \\
\hline Itaparica & 69 & 4,3 & 14,5 & 27,5 & 13,0 & 4,3 & 7,2 & 10,1 & 18,8 \\
\hline Lauro de Freitas & 594 & 5,6 & 12,1 & 24,2 & 9,8 & 10,1 & 5,1 & 14,1 & 19,0 \\
\hline Madre de Deus & 42 & 9,5 & 9,5 & 35,7 & 7,1 & 4,8 & 9,5 & 4,8 & 19,0 \\
\hline Salvador & 13.015 & 6,7 & 14,1 & 28,4 & 10,8 & 6,9 & 2,7 & 12,6 & 17,7 \\
\hline S. Francisco do Conde & 108 & 6,5 & 12,0 & 37,0 & 11,1 & 1,9 & 2,8 & 9,3 & 19,4 \\
\hline Simões Filho & 532 & 8,6 & 9,0 & 25,4 & 7,9 & 9,4 & 4,3 & 15,2 & 20,1 \\
\hline Vera Cruz & 109 & 8,3 & 10,1 & 27,5 & 8,3 & 1,8 & 12,8 & 12,8 & 18,3 \\
\hline
\end{tabular}

Fonte: DATASUS. http://tabnet.datasus.gov.br/cgi/deftohtm.exe?sim/cnv/obtba.def. Acesso em 13/08/2004 
Tabela 12 - Mulheres de 10 anos ou mais, por filhos nascidos vivos, número de filhos nascidos vivos por mulher e Taxa de Fecundidade, segundo os municípios Bahia e Região Metropolitana de Salvador, 2000

\begin{tabular}{|c|c|c|c|c|c|c|c|c|c|c|}
\hline \multirow[b]{3}{*}{ Bahia, RMS e Municípios } & \multicolumn{10}{|c|}{ Mulheres residentes, de 10 anos ou mais de idade } \\
\hline & \multirow[b]{2}{*}{ Total } & \multicolumn{4}{|c|}{ Tiveram filhos nascidos vivos } & \multicolumn{4}{|c|}{$\begin{array}{l}\text { Distribuição das mulheres que tiveram filhos } \\
\text { nascidos vivos (\%) }\end{array}$} & \multirow[b]{2}{*}{$\begin{array}{c}\text { Taxa de } \\
\text { fecundidade } \\
(*)\end{array}$} \\
\hline & & Total & $\begin{array}{l}\text { um ou dois } \\
\text { filhos }\end{array}$ & $\begin{array}{l}\text { Três ou } \\
\text { quatro } \\
\text { filhos } \\
\end{array}$ & $\begin{array}{c}\text { cinco ou } \\
\text { mais filhos }\end{array}$ & Total & $\begin{array}{l}\text { um ou dois } \\
\text { filhos }\end{array}$ & $\begin{array}{l}\text { Três ou } \\
\text { quatro } \\
\text { filhos } \\
\end{array}$ & \begin{tabular}{|c|} 
cinco ou \\
mais filhos
\end{tabular} & \\
\hline Bahia & 5.289.179 & 3.072 .653 & 1.282 .748 & 791.868 & 998.037 & 100,0 & 41,7 & 25,8 & 32,5 & 2,41 \\
\hline Metropolitana de Salvador & 1.321 .239 & 753.716 & 409.503 & 195.781 & 148.432 & 100,0 & 54,3 & 26,0 & 19,7 & 1,79 \\
\hline Camaçari & 63.831 & 37.907 & 18.415 & 10.173 & 9.319 & 100,0 & 48,6 & 26,8 & 24,6 & 2,07 \\
\hline Candeias & 31.481 & 18.311 & 8.301 & 4.958 & 5.052 & 100,0 & 45,3 & 27,1 & 27,6 & 2,22 \\
\hline Dias D'Ávila & 17.935 & 10.792 & 5.049 & 2.808 & 2.935 & 100,0 & 46,8 & 26,0 & 27,2 & 2,16 \\
\hline Itaparica & 7.632 & 4.729 & 2.216 & 1.251 & 1.262 & 100,0 & 46,9 & 26,5 & 26,7 & 2,30 \\
\hline Lauro de Freitas & 46.698 & 27.826 & 14.874 & 7.637 & 5.315 & 100,0 & 53,5 & 27,4 & 19,1 & 1,84 \\
\hline Madre de Deus & 4.982 & 3.064 & 1.565 & 764 & 735 & 100,0 & 51,1 & 24,9 & 24,0 & 2,14 \\
\hline Salvador & 1.089 .427 & 616.279 & 343.371 & 159.029 & 113.879 & 100,0 & 55,7 & 25,8 & 18,5 & 1,72 \\
\hline São Francisco do Conde & 10.439 & 5.944 & 2.476 & 1.458 & 2.010 & 100,0 & 41,7 & 24,5 & 33,8 & 2,33 \\
\hline Simões Filho & 37.224 & 21.863 & 10.210 & 5.777 & 5.876 & 100,0 & 46,7 & 26,4 & 26,9 & 2,21 \\
\hline Vera Cruz & 11.590 & 7.001 & 3.026 & 1.926 & 2.049 & 100,0 & 43,2 & 27,5 & 29,3 & 2,32 \\
\hline
\end{tabular}

Fonte: IBGE: Censo Demográfico de 2000

$\left({ }^{*}\right)$ Número médio de filhos nascidos vivos por mulher do grupo etário específico 
Tabela 13 - Mulheres de 15 a 49 anos, por filhos nascidos vivos, número de filhos nascidos vivos por mulher e

Taxa de Fecundidade, segundo os municípios

Bahia e Região Metropolitana de Salvador, 2000

Mulheres residentes de 15 a 49 anos de idade (em idade reprodutiva)

\begin{tabular}{|c|c|c|c|c|c|c|c|c|c|c|}
\hline \multirow{3}{*}{$\begin{array}{c}\text { Áreas geográficas } \\
\text { selecionadas }\end{array}$} & \multicolumn{10}{|c|}{ Mulheres residentes de 15 a 49 anos de idade (em idade reprodutiva) } \\
\hline & \multirow[b]{2}{*}{ Total } & \multicolumn{4}{|c|}{ Tiveram filhos nascidos vivos } & \multicolumn{4}{|c|}{$\begin{array}{l}\text { Distribuição das mulheres que tiveram filhos } \\
\text { nascidos vivos (\%) }\end{array}$} & \multirow[b]{2}{*}{$\begin{array}{c}\text { Taxa de } \\
\text { fecundidade } \\
(*)\end{array}$} \\
\hline & & Total & $\begin{array}{l}\text { um ou dois } \\
\text { filhos }\end{array}$ & $\begin{array}{l}\text { Três ou } \\
\text { quatro } \\
\text { filhos }\end{array}$ & $\begin{array}{c}\text { cinco ou } \\
\text { mais filhos }\end{array}$ & Total & $\begin{array}{l}\text { um ou dois } \\
\text { filhos }\end{array}$ & $\begin{array}{l}\text { Três ou } \\
\text { quatro } \\
\text { filhos }\end{array}$ & \begin{tabular}{|c} 
cinco ou \\
mais filhos
\end{tabular} & \\
\hline Bahia & 3.509 .768 & 2.150 .064 & 1.136 .574 & 614.54 & 398.94 & 100,0 & 52,9 & 28,6 & 18,6 & 1,87 \\
\hline Metropolitana de Salvador & 953.810 & 557.445 & 357.741 & 141.505 & 58.199 & 100,0 & 64,2 & 25,4 & 10,4 & 1,43 \\
\hline Camaçari & 47.504 & 30.926 & 17.296 & 8.667 & 4.963 & 100,0 & 55,9 & 28,0 & 16,0 & 1,84 \\
\hline Candeias & 22.625 & 14.059 & 7.759 & 4.146 & 2.154 & 100,0 & 55,2 & 29,5 & 15,3 & 1,78 \\
\hline Dias D'Ávila & 13.066 & 8.619 & 4.708 & 2.447 & 1.464 & 100,0 & 54,6 & 28,4 & 17,0 & 1,88 \\
\hline Itaparica & 5.281 & 3.499 & 1.987 & 986 & 526 & 100,0 & 56,8 & 28,2 & 15,0 & 1,80 \\
\hline Lauro de Freitas & 34.507 & 21.908 & 13.355 & 6.047 & 2.506 & 100,0 & 61,0 & 27,6 & 11,4 & 1,61 \\
\hline Madre de Deus & 3.615 & 2.322 & 1.489 & 582 & 251 & 100,0 & 64,1 & 25,1 & 10,8 & 1,60 \\
\hline Salvador & 784.671 & 449.426 & 296.816 & 110.969 & 41.641 & 100,0 & 66,0 & 24,7 & 9,3 & 1,36 \\
\hline São Francisco do Conde & 7.414 & 4.453 & 2.265 & 1.207 & 981 & 100,0 & 50,9 & 27,1 & 22,0 & 1,91 \\
\hline Simões Filho & 27.120 & 17.193 & 9.470 & 4.874 & 2.849 & 100,0 & 55,1 & 28,3 & 16,6 & 1,84 \\
\hline Vera Cruz & 8.007 & 5.040 & 2.596 & 1.580 & 864 & 100,0 & 51,5 & 31,3 & 17,1 & 1,84 \\
\hline
\end{tabular}

Fonte: IBGE: Censo Demográfico de 2000

${ }^{*}$ ) Número médio de filhos nascidos vivos por mulher do grupo etário específico 
Tabela 14 - Saldo migratório interestadual e intra-estadual, Região Metropolitana de Salvador, 1995-2000

\begin{tabular}{|c|c|c|c|}
\hline Municípios & $\begin{array}{l}\text { Saldo da migração } \\
\text { interestadual }\end{array}$ & $\begin{array}{l}\text { Saldo da migração } \\
\text { intra-estadual }\end{array}$ & $\begin{array}{l}\text { Saldo migratório } \\
\text { (Total) }\end{array}$ \\
\hline Camaçari & 1.558 & 12.445 & 14.003 \\
\hline Candeias & -242 & 143 & -99 \\
\hline Dias d'Ávila & 194 & 5.265 & 5.459 \\
\hline Itaparica & -112 & 158 & 46 \\
\hline Lauro de Freitas & 2.308 & 17.844 & 20.152 \\
\hline Madre de Deus & 92 & 648 & 740 \\
\hline Salvador & -19.785 & -2.299 & -22.084 \\
\hline São Francisco do Conde & -26 & 504 & 478 \\
\hline Simões Filho & 957 & 8.105 & 9.062 \\
\hline Vera Cruz & 168 & 2.226 & 2.394 \\
\hline Total & -14.889 & 45.039 & 30.150 \\
\hline
\end{tabular}

Fonte: IBGE. Censo Demográfico 2000 
Tabela 15 - Imigrantes interestaduais por Grandes Regiões de origem, segundo os municípios de residência em 2000 Região Metropolitana de Salvador, 1995-2000

\begin{tabular}{|c|c|c|c|c|c|c|c|c|c|c|c|c|}
\hline \multirow{3}{*}{ Municípios } & \multicolumn{12}{|c|}{ Grandes Regiões } \\
\hline & \multicolumn{2}{|c|}{ Região Norte } & \multicolumn{2}{|c|}{ Região Nordeste } & \multicolumn{2}{|c|}{ Região Sudeste } & \multicolumn{2}{|c|}{ Região Sul } & \multicolumn{2}{|c|}{ Região Centro Oeste } & \multicolumn{2}{|c|}{$\begin{array}{c}\text { Brasil sem } \\
\text { especificação }\end{array}$} \\
\hline & Absoluto & $\%$ & Absoluto & $\%$ & Absoluto & $\%$ & Absoluto & $\%$ & Absoluto & $\%$ & Absoluto & $\%$ \\
\hline Camaçari & 89 & 2,3 & 1.778 & 45,8 & 1.711 & 44,1 & 68 & 1,8 & 139 & 3,6 & 97 & 2,5 \\
\hline Candeias & 0 & 0,0 & 398 & 63,6 & 180 & 28,7 & 30 & 4,8 & 18 & 2,9 & 0 & 0,0 \\
\hline Dias D'Ávila & 50 & 5,3 & 581 & 61,4 & 243 & 25,7 & 42 & 4,4 & 11 & 1,2 & 19 & 2,0 \\
\hline Itaparica & 0 & 0,0 & 71 & 53,5 & 59 & 44,8 & 0 & 0,0 & 0 & 0,0 & 2 & 1,7 \\
\hline Lauro de Freitas & 51 & 1,7 & 972 & 33,0 & 1.482 & 50,3 & 347 & 11,8 & 50 & 1,7 & 43 & 1,5 \\
\hline Madre de Deus & 0 & 0,0 & 54 & 27,8 & 134 & 68,8 & 0 & 0,0 & 7 & 3,4 & 0 & 0,0 \\
\hline Salvador & 1.527 & 4,3 & 11.343 & 31,8 & 18.119 & 50,7 & 2.291 & 6,4 & 1.973 & 5,5 & 462 & 1,3 \\
\hline São Francisco do Conde & 0 & 0,0 & 36 & 29,0 & 50 & 40,5 & 14 & 11,1 & 12 & 9,7 & 12 & 9,7 \\
\hline Simões Filho & 79 & 4,9 & 678 & 41,8 & 763 & 47,1 & 42 & 2,6 & 58 & 3,6 & 0 & 0,0 \\
\hline Vera Cruz & 0 & 0,0 & 75 & 23,2 & 123 & 38,1 & 82 & 25,4 & 27 & 8,3 & 16 & 5,0 \\
\hline Total & 1.796 & 3,9 & 15.987 & 34,4 & 22.866 & 49,2 & 2.916 & 6,3 & 2.295 & 4,9 & 651 & 1,4 \\
\hline
\end{tabular}

Fonte: IBGE: Censo Demográfico de 2000 
Tabela 16 - Emigrantes interestaduais por Grandes Regiões de origem, segundo os municípios de residência em 2000 Região Metropolitana de Salvador, 1995-2000

\begin{tabular}{|c|c|c|c|c|c|c|c|c|c|c|c|}
\hline \multirow{3}{*}{ Municípios } & \multicolumn{10}{|c|}{ Grandes Regiões } & \multirow{3}{*}{ Total } \\
\hline & \multicolumn{2}{|c|}{ Região Norte } & \multicolumn{2}{|c|}{ Região Nordeste } & \multicolumn{2}{|c|}{ Região Sudeste } & \multicolumn{2}{|c|}{ Região Sul } & \multicolumn{2}{|c|}{ Região Centro Oeste } & \\
\hline & Absoluto & $\%$ & Absoluto & $\%$ & Absoluto & $\%$ & Absoluto & $\%$ & Absoluto & $\%$ & \\
\hline Camaçari & 51 & 2,2 & 915 & 39,4 & 1.122 & 48,3 & 100 & 4,3 & 136 & 5,9 & 2.324 \\
\hline Candeias & 0 & 0,0 & 131 & 15,1 & 628 & 72,3 & 64 & 7,4 & 46 & 5,3 & 869 \\
\hline Dias D'Ávila & 52 & 6,9 & 236 & 31,4 & 407 & 54,1 & 6 & 0,8 & 51 & 6,8 & 752 \\
\hline Itaparica & 0 & 0,0 & 18 & 7,3 & 189 & 77,0 & 38 & 15,7 & 0 & 0,0 & 245 \\
\hline Lauro de Freitas & 10 & 1,5 & 244 & 38,3 & 356 & 55,8 & 6 & 0,9 & 23 & 3,5 & 639 \\
\hline Madre de Deus & 0 & 0,0 & 15 & 15,0 & 88 & 85,0 & 0 & 0,0 & 0 & 0,0 & 103 \\
\hline Salvador & 1.477 & 2,7 & 12.638 & 22,8 & 35.020 & 63,1 & 2.310 & 4,2 & 4.053 & 7,3 & 55.499 \\
\hline São Francisco do Conde & 0 & 0,0 & 11 & 7,1 & 129 & 86,1 & 0 & 0,0 & 10 & 6,8 & 150 \\
\hline Simões Filho & 21 & 3,2 & 77 & 11,6 & 502 & 75,6 & 5 & 0,7 & 59 & 8,9 & 665 \\
\hline Vera Cruz & 0 & 0,0 & 65 & 41,7 & 91 & 58,3 & 0 & 0,0 & 0 & 0,0 & 156 \\
\hline Total & 1.611 & 2,6 & 14.352 & 23,4 & 38.532 & 62,8 & 2.529 & 4,1 & 4.378 & 7,1 & 61.402 \\
\hline
\end{tabular}

Fonte: IBGE: Censo Demográfico de 2000 


\section{REFERÊNCIAS}

CARVALHO, Inaiá M. M. Família e pobreza. In: SEI. Pobreza e desigualdades sociais. Salvador: 2003. p. 117-134 (Série estudos e pesquisas, 63).

GUIMARÃES, José Ribeiro Soares pobreza e desigualdade no Brasil: do discurso hegemônico e medição espúria às raízes da questão. In: SEI. Pobreza e desigualdades sociais. Salvador: 2003, p. 85-116 (Série estudos e pesquisas, 63).

IBGE. Censo demográfico 2000 - características da população e dos domicilios, resultados do universo. Rio de Janeiro: 2001.

. Censo demográfico 2000 - primeiros resultados da amostra. Rio de Janeiro: 2001.

. Censo demográficos 1991, 2000 - Microdados da amostra. Rio de Janeiro: 2002. CD-ROM.

MARTINE, George. Processos recentes de concentração e desconcentração urbana no Brasil: determinantes e implicações. Bahia Análise \& Dados. Salvador: SEI, v.3, p. 22-38,1993.

PNUD/IPEA/Fundação João Pinheiro. Novo Atlas do Desenvolvimento Humano no Brasil 2002. Acesso em http://www.pnud.org.br/atlas. 



\title{
AS "CIDADES" DE SALVADOR
}

\author{
Inaiá Maria Moreira de Carvalho* \\ Gilberto Corso Pereira**
}

Casarios coloniais, igrejas barrocas, praias ensolaradas... Normalmente associadas a Salvador, essas imagens não retratam todo o panorama da velha capital e da sua região metropolitana, onde também se encontram algumas ilhas da modernidade e vastas áreas marcadas pela precariedade, pela pobreza e pela segregação.

Espelhando diferenças econômicas, étnicas, sociais ou culturais e constituindo uma das marcas das cidades contemporâneas, a segregação vem sendo objeto de preocupação de cientistas sociais e urbanistas desde a primeira metade do século XX. De início, a análise dessa segregação indica que ela se reportou à divisão entre brancos e negros nas cidades americanas, sancionada por normas legais até 0 movimento pelos direitos civis da década de cinqüenta, estendendo-se, posteriormente, à segregação entre brancos e minorias etno-raciais. Em países como a França, as discussões têm privilegiado a segregação entre categorias socioocupacionais, comandada pelo mercado e com uma maior conotação de classe, que foi acentuada com a concentração de população mais pobre em conjuntos habitacionais de interesse social nas periferias metropolitanas.

Com essa mesma conotação, nos países da América Latina, estudos recentes vêm reconstruindo os seus contornos nas áreas metropolitanas e discutindo como as transformações econômicas e sociais dos últimos anos têm agravado a sua

\footnotetext{
* Pesquisadora do Centro de Recursos Humanos da Universidade Federal da Bahia. Professora do Mestrado em Políticas Sociais e Cidadania da Universidade Católica de Salvador e do Programa de Pós-Graduação em Ciências Sociais da Universidade Federal da Bahia. Bolsista do CNPq.

** Professor da Faculdade de Arquitetura da Universidade Federal da Bahia e do Programa de PósGraduação em Arquitetura e Urbanismo e do Mestrado em Geografia da Universidade Federal da Bahia.
} 
intensidade e perversão. Além disso, a questão da segregação social assumiu nova viabilidade e destaque com a difusão do paradigma das cidades globais que, supostamente, seriam marcadas por uma tendência à polarização social e espacial (Sassen, 1991; Shapira, 2000; Preteceille, 2004; Sabatini; Cáceres; Cerda, 2004; Ribeiro, 2000, 2004).

O consenso existente sobre a relevância do referido fenômeno, porém, não se estende à sua compreensão. Alguns autores entendem a segregação como uma separação forçada e legalmente estabelecida, associando-a a casos como os do gueto judeu, do gueto negro ou do apartheid da África do Sul, ou até questionando a aplicabilidade desse conceito a realidades como a do Brasil (Vasconcelos, 2004; Marcuse, 2004). Enfatizando o caráter histórico e plural desse fenômeno, porém, outros estudiosos consideram que a segregação pode ser analisada a partir do grau de proximidade espacial ou de concentração territorial de famílias pertencentes a um mesmo grupo, seja este definido em termos étnicos, socioeconômicos ou até religiosos, entre outros aspectos, com a concentração de determinados grupos em locais específicos das cidades e a constituição de grandes áreas relativamente homogêneas. $\mathrm{E}$, nesse sentido, ela será abordada no presente trabalho.

No Brasil, estudos sobre esse tipo de área, como as favelas e as periferias, constituem uma parte expressiva da produção sobre a questão urbana. Contudo, o avanço do debate sobre a segregação vai se dar a partir da década de noventa, com os trabalhos efetuados por Villaça (1998) e Caldeira (2000) e com as pesquisas desenvolvidas principalmente pelo Observatório das Metrópoles e pelo Centro de Estudos da Metrópole sobre a configuração atual das áreas metropolitanas (Ribeiro, 2000, 2004; Marques; Torres, 2005).

Tanto esses estudos quanto os que foram efetuados em outros países, por Mattos (2004), Kaztman; Wordmald (2002), Shapira (2000), Veiga (2006) ou Duhau (2006), ressaltam como a integração dos países latino-americanos à dinâmica da globalização (com a reestruturação produtiva e outros fenômenos a ela associados) tem afetado a conformação das áreas metropolitanas, contribuindo para a persistência e consolidação de uma estrutura urbana segmentada e segregada, onde a estratificação social tem uma clara expressão territorial.

Ainda que as transformações em apreço não tenham um impacto homogêneo e convergente nos diversos países, e que no fundamental se mantenha a conformação, a paisagem urbana e a identidade construída historicamente em cada cidade, certas tendências são comuns e dominantes na dinâmica metropolitana atual. Estão entre elas: um decréscimo demográfico das antigas áreas centrais e um forte crescimento para as bordas e para o periurbano, acentuando uma metropolização estendida que prolonga a cidade para várias direções; a conformação de sistemas produtivos organizados reticularmente, como base para a formação de cidades regiões, com a constituição de novas áreas de negócios, fora do centro tradicional, ou de zonas industriais em áreas mais distantes da periferia urbana ou em cidades próximas à aglomeração central, integrando espaços cada vez mais extensos, articulados por 
todo tipo de fluxos, materiais e não materiais; a proliferação de artefatos urbanos de grande impacto na estrutura e uma policentralização metropolitana, como edifícios corporativos, shoppings, complexos de cinema, centros empresariais e de convenções, parques temáticos e hotéis de luxo e de superluxo; mudanças nos padrões habitacionais, com a proliferação de condomínios fechados e protegidos (inclusive no periurbano), para onde as camadas de média e alta renda se dirigem em busca de segurança e qualidade de vida, afastando-se da poluição e dos riscos da grande cidade; uma maior concentração social e espacial da riqueza e da pobreza, com 0 aumento da auto-segregação dos ricos e do isolamento de "pobres rodeados de pobres" (Kaztman; Wordmald, 2002) em espaços cada vez mais cristalizados e homogêneos; espaços marcados pela superposição de carências, pela vulnerabilidade social, pela presença das drogas e por uma significativa conflitividade e violência.

\section{A APROPRIAÇÃO SOCIAL DO ESPAÇO EM SALVADOR}

Tendências dessa ordem vêm interferindo na conformação do espaço e na sua apropriação diferenciada pelas diversas categorias sociais em Salvador e em sua região metropolitana. Para o seu melhor entendimento, vale lembrar como a evolução econômica da área, apresentada no capítulo inicial deste livro, também envolve mudanças radicais na sua conformação urbana.

$\mathrm{Na}$ Salvador colonial, o Recôncavo, a região em torno da Baía de Todos os Santos, onde hoje estão cidades como Cachoeira, Santo Amaro, São Francisco do Conde, desempenhava um papel de relevo na vida econômica da cidade que, desde cedo, já apresentava uma ocupação densa nas cumeadas próximas à Baía de Todos os Santos. Entre os anos 1940 e 1950, a cidade experimentou um crescimento demográfico causado, em parte, pelas migrações e, nesse período, a estrutura espacial de Salvador já se modificava em função de vários fatores, como a reestruturação do centro da cidade, que ia tendo suas funções, até então predominantemente residenciais, substituídas. A população de alta renda, que até os anos quarenta ali se concentrara, passou a ocupar outros espaços; já a população de baixa renda ocupou as velhas edificações e fez crescer a demanda por novas áreas residenciais, forçando a expansão da periferia urbana, então representada pelos fundos de vale não drenados e por outras áreas ainda não urbanizadas, particularmente nas encostas.

O Mapa 1 ilustra essa expansão da área urbana, mostrando, primeiro, o local de fundação da cidade, onde hoje fica o Centro Histórico; em segundo lugar, a ocupação ainda concentrada junto da orla da Baía de Todos os Santos, no início do século XX; e, em terceiro, a cidade começando sua expansão, com alguma ocupação da Orla Atlântica, nos anos quarenta.

Nessa década, o crescimento de Salvador levou à contratação do escritório do engenheiro Mário Leal Ferreira e à elaboração do código de urbanismo de 1948. Áreas vazias começaram a ser ocupadas pelos moradores de baixa renda, ocorrendo, 


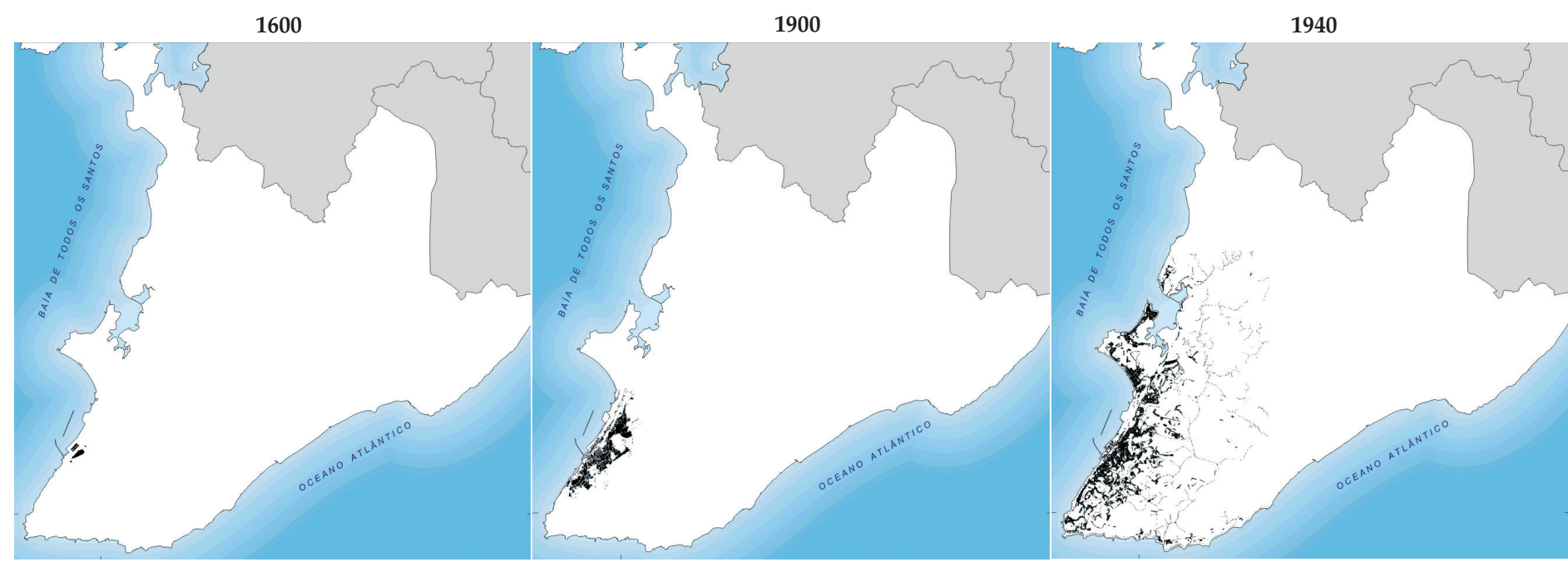


em 1946, a primeira invasão de terras para a construção de habitações: a invasão ${ }^{1}$ do Corta Braço, hoje bairro de Pero Vaz. Na década de sessenta se deu a abertura das avenidas de vale, previstas no plano de Ferreira, quando a expansão do sistema viário incorporou novos espaços ao tecido urbano, aumentando o valor das áreas próximas a essas avenidas.

À época que a expansão e modernização da velha capital baiana foram desencadeadas, o que se tinha era uma região urbana pobre e incipiente, polarizada por uma cidade praticamente estagnada ao longo de várias décadas, que exigia uma transformação. $E$ isso se deu de forma bastante rápida e abrupta, entre as décadas de 1960 e 1970, com a realização de grandes obras que acompanharam e anteciparam os vetores da expansão urbana e uma intensa ocupação informal de famílias de baixa renda na periferia. Nessa fase, comprometida com uma modernização excludente e com os interesses do capital imobiliário, a Prefeitura de Salvador, que detinha a maioria das terras do município, transferiu sua propriedade para (algumas poucas) mãos privadas, através da Lei da Reforma Urbana, em 1968. A abertura das avenidas de vale extirpou do tecido urbano mais valorizado um conjunto significativo de assentamentos de população pobre, que ocupavam tradicionalmente os fundos até então inacessíveis dos numerosos vales de Salvador. Além disso, o governo municipal erradicou invasões populares localizadas na orla marítima, área reservada ao turismo, outro componente da estratégia de crescimento e modernização da cidade (Cf. Brandão, 1981; Souza, 2000).

$\mathrm{Na}$ década de 1980, consolidou-se um novo centro urbano, impulsionado por grandes empreendimentos públicos e privados realizados na década anterior, destacandose a construção daAv. Paralela, do CentroAdministrativo da Bahia, da nova Estação Rodoviária e do Shopping Iguatemi. Essa nova centralidade não apenas direcionou a expansão urbana no sentido da orla norte, como teve impacto na dinâmica do centro tradicional na área antiga da cidade, contribuindo para o seu gradativo esvaziamento.

Essas intervenções, associadas à realização de investimentos complementares, pesados e seletivos, centrados na infra-estrutura e no projeto industrial, interferiram decisivamente na conformação de um novo padrão de produção do espaço urbano, com a configuração de três vetores bem diferenciados de expansão da cidade: a Orla Marítima norte, o "Miolo" e o Subúrbio Ferroviário, no litoral da Baía de Todos os Santos. O primeiro constitui a "área nobre" da cidade, local de moradia, serviços e lazer, onde se concentram a riqueza, os investimentos públicos, os equipamentos urbanos e os interesses da produção imobiliária. O segundo, localizado

\footnotetext{
${ }^{1}$ Assim passaram a ser designadas as áreas de habitação popular que se formaram ou cresceram por "ocupação espontânea" direta e, sobretudo, de forma coletiva, iniciadas por famílias sem recursos e sem moradia, à revelia do proprietário fundiário, portanto, sem consentimento, intermediação ou comercialização (Souza, 1990). Depois da invasão do Corta Braço esse procedimento tornou-se comum e sua própria denominação terminou por ser absorvida pelos moradores da cidade em geral, sem a conotação pejorativa que possui em outros lugares, com o reconhecimento de que isto respondia a uma necessidade básica de quem não tinha outra alternativa.
} 
no centro geográfico do município, começou a ser ocupado pela implantação de conjuntos residenciais para a "classe média baixa" na fase áurea da produção imobiliária através do Sistema Financeiro de Habitação, tendo a sua expansão continuada por loteamentos populares e sucessivas invasões coletivas, com uma disponibilidade de equipamentos e serviços bastante restrita. Finalmente, o Subúrbio Ferroviário teve sua ocupação impulsionada inicialmente pela implantação da linha férrea, em 1860, constituindo, a partir da década de 1940, a localização de muitos loteamentos populares, que foram ocupados nas décadas seguintes sem o devido controle urbanístico, com suas áreas livres também invadidas. Transformou-se em uma das áreas mais carentes e problemáticas da cidade, concentrando uma população extremamente pobre e sendo marcada pela precariedade habitacional, pelas deficiências de infra-estrutura e serviços básicos e, mais recentemente, por altos índices de violência (Franco; Santos; Gabrielli, 1998; Souza, 2000). Assim, a apropriação diferenciada do território urbano se consolidou e intensificou com 0 surgimento da Salvador moderna.

Nos primórdios da cidade a segregação se definia, mais acentuadamente, no interior do domicílio e no âmbito da edificação, com a separação de escravos e agregados, quase sempre nos andares inferiores dos sobrados das famílias mais abastadas. Em termos de inserção urbana, os primeiros sinais de segregação por estratificação de renda no espaço construído se manifestaram nas franjas da ocupação contínua, com as novas habitações edificadas no final do século XIX para famílias ricas, partindo do que era então o centro da cidade, na direção sul (Campo Grande, Vitória e Graça). E, para as famílias pobres, na direção norte (Lapinha, Soledade e Cidade Nova). Essa apropriação diferenciada do espaço urbano se delineia com maior nitidez, primeiro, pela contingência da proximidade dos operários junto às primeiras fábricas nos arredores da cidade e, a posteriori, pela indução da legislação urbanista que entra em vigor através do Código de Posturas Municipais, de 1920 e 1926, que introduziu as primeiras normas que condicionaram a localização das habitações para as camadas de baixa renda (Souza, 2000, 2002).

A partir da década de sessenta, como já foi visto, a nova dinâmica econômica e urbana da cidade incrementou a ocupação da orla pelas classes médias e altas, remetendo a população de baixa renda para áreas distantes e desequipadas do Miolo, dos Subúrbios ou de Lauro de Freitas e Simões Filho, junto aos limites de Salvador. Em Lauro de Freitas, município com cerca de 10.000 habitantes em 1970, que sobreviviam basicamente da produção e comercialização de hortigranjeiros e de pesca, começou a haver uma enorme proliferação de loteamentos populares no distrito de Itinga, vizinho a São Cristóvão, bairro popular já urbanizado de Salvador, situado no final da Avenida Paralela e próximo ao aeroporto, onde já circulavam algumas linhas de transporte coletivo. Naquela área, então ocupada por chácaras e pequenas fazendas, dado o baixo preço das terras e às reduzidas exigências e fiscalização do poder público municipal, diversos incorporadores passaram a vender pequenos lotes, literalmente "no meio do mato", sem arruamento, água, transporte ou luz, que podiam 
ser pagos em até 60 meses $^{2}$ (Dias, 2005).

Na década de 1980, com a implantação do Pólo Petroquímico de Camaçari e a abertura da Estrada do Coco, que "diminuía" a distância entre Salvador e Lauro de Freitas, o capital imobiliário começou a oferecer empreendimentos mais qualificados na orla marítima desse município, que já se conurbava com a capital baiana. O primeiro e mais importante deles foi Vilas do Atlântico, apresentado como um novo conceito de moradia, associado a uma vida saudável e integrada à natureza, com uma comunidade homogênea e longe do barulho, da poluição, da criminalidade e de outros males urbanos, ou como uma alternativa de veraneio mais acessivel que a ilha de Itaparica para os habitantes de Salvador.

Situados estrategicamente a cerca de 20 quilômetros de Salvador e de Camaçari, tanto Vilas como outros loteamentos e condomínios fechados que proliferam nas suas imediações atraíram segmentos de média e alta renda de Salvador, até porque muitos foram trabalhar no Pólo, na Ford ou em outros empreendimentos da região, transformando a orla marítima do município em uma continuação da área "nobre" da capital. Nos demais municípios da RMS predomina uma população de baixa renda, em boa parte seduzida pela implantação das indústrias e de outros empreendimentos, mas sem maiores e melhores oportunidades de ocupação.

\section{ESTRUTURA URBANA E SEGREGAÇÃO}

A apropriação diferenciada do espaço na RMS foi detalhada e analisada através da metodologia que vem sendo utilizada pelo Observatório das Metrópoles (Ribeiro; Lago, 2000), com base nos dados dos Censos de 1991 e 2000 sobre a ocupação da população economicamente ativa da RMS. As ocupações foram classificadas e agregadas em categorias mais abrangentes - denominadas como CATs - a partir do pressuposto teórico de que o trabalho constitui a variável básica para a compreensão das hierarquias e da estrutura social, traduzindo em grande medida, o lugar que as pessoas ocupam nas relações econômicas e a dimensão simbólica que tem esse lugar (Bourdieu, 1989).

Em um segundo momento, foi analisada a distribuição dessas categorias no espaço da metrópole, usando como recorte territorial áreas definidas por uma agregação de setores censitários utilizada no censos demográfico de 2000 pelo IBGE ${ }^{3}$

\footnotetext{
${ }^{2} \mathrm{~A}$ extrema precariedade desses loteamentos - em boa parte hoje urbanizados - foi ressaltada por antigos moradores de Itinga em entrevistas realizadas por Dias (2005), mencionando como tinham que se organizar em grupos para transitar por verdadeiras picadas, onde encontravam, comumente, cobras, macacos e jacarés.

${ }^{3}$ As Áreas de Expansão Domiciliar - AEDs, ou áreas de ponderação, são áreas "que conjugam critérios tais como tamanho, contigüidade (no sentido de serem construídas por setores limítrofes com sentido geográfico) e homogeneidade em relação a um conjunto de características populacionais e de infraestrutura conhecida" (IBGE, 2002). Elas representam a menor unidade territorial que o IBGE disponibilizou para os dados da amostra do Censo demográfico de 2000. O processo de construção
} 
e adaptada para os setores censitários utilizados no censo demográfico anterior, de 1991. Levando em conta como as diversas categorias ocupacionais encontravam-se representadas nestas diversas áreas da Região Metropolitana de Salvador, foi elaborada uma tipologia que as classificou em superior, média-superior, média, médiapopular, popular, popular-inferior, popular operário agrícola e popular agrícola, ${ }^{4} \mathrm{de}$ acordo com a composição dos seus moradores,

$\mathrm{Na}$ categoria superior predominam os grandes empresários locais, dirigentes do setor público e do setor privado, ao lado do grupo denominado como intelectuais (ou seja, profissionais de nível superior, autônomos ou empregados); na média superior o predomínio é dos intelectuais; na média os profissionais de nível superior se misturam com pequenos empregadores e trabalhadores em ocupações técnicas, de supervisão, de escritório, ocupações médias de educação e saúde e atividades similares; a média popular (que só vai aparecer na análise baseada nos dados censitários de 1991) tem índices consideráveis das chamadas ocupações médias, mas, também, tem grande presença de categorias populares, como trabalhadores manuais da indústria e de serviços auxiliares e trabalhadores do comércio; nas áreas de caráter popular predominam trabalhadores manuais da indústria e do comércio, assim como prestadores de serviços com alguma qualificação; nas classificadas como popular inferior há uma conjugação desses trabalhadores com prestadores de serviços não qualificados, trabalhadores domésticos, ambulantes e biscateiros. Como popular-agrícolas foram classificadas aquelas que possuem uma expressiva freqüência de trabalhadores rurais, áreas essas menos urbanizadas e com baixa densidade demográfica, encontradas em alguns municípios da RMS, como São Francisco do Conde, Itaparica, Vera Cruz, Lauro de Freitas e Camaçari. Pela trajetória econômica e características de sua industrialização recente, Salvador e a RMS nunca possuíram uma classe operária numericamente expressiva ou

de áreas de ponderação consistiu em agregar setores censitários de 1991 tomando como referência de recorte espacial as áreas de 2000 , de modo que fosse possivel uma comparação entre a tipologia sócioespacial de 1991 e 2000.

${ }^{4}$ Essa classificação foi realizada através de técnicas como a Análise Fatorial por Correspondência Binária e o Sistema de Classificação Hierárquica Ascendente (CHA). A primeira cria fatores pela ordem de explicação do problema, permitindo a diminuição da dimensionalidade do universo com que se está trabalhando e o conhecimento da importância de cada variável na composição da variação dos principais fatores. A segunda é um instrumento para definir agrupamentos a partir das informações dos fatores extraídos na análise fatorial, levando em conta a proximidade dos perfis das áreas e sua distância em relação ao perfil médio. Para se chegar ao resultado final, com a identificação dos tipos de área e resultados mais refinados, foi necessário proceder-se a uma seqüência de análises fatoriais e operações de classificações, uma vez que, fora dos espaços onde predominam as camadas superiores ou as camadas popular e agrícola, nas demais áreas o perfil social não se expressa com muita nitidez, em virtude de um alto grau de mistura social existente.

Em trabalhos publicados anteriormente sobre a segregação sócioespacial em Salvador algumas dessas áreas tinham outra denominação (popular-sub-proletária, por exemplo, ao invés de popular inferior). A designação atual teve o objetivo de torná-la homogênea entre as várias metrópoles que estão sendo pesquisadas pela rede do Observatório e refletir com mais clareza a sua composição social. 
bairros com essa composição. ${ }^{5}$ Contudo, em algumas localidades de caráter popular agrícola o peso relativo de trabalhadores da indústria moderna (como da Petrobrás ou do Pólo Petroquímico) e da construção civil, na sua reduzida população ocupada, levou a sua classificação como popular operário agrícola.

Analisando-se os padrões de apropriação do espaço de acordo com essa classificação, fica patente a ocupação da Orla Atlântica de Salvador e de Lauro de Freitas, (com quem o pólo metropolitano já se conurba) pelos grandes empregadores, dirigentes e trabalhadores intelectuais, em uma mancha praticamente contínua, limitada a Noroeste pela Avenida Paralela, eixo viário importante que faz a ligação de Salvador com o vetor de expansão do Litoral Norte e se configura como a fronteira dessa "cidade" com as áreas populares. Ressalvando-se os enclaves que constituem o Nordeste de Amaralina, antiga invasão que se consolidou como um bairro popular de alta densidade demográfica, rompendo a continuidade da mancha, o que também ocorre com o bairro da Boca do Rio, um pouco mais ao norte, e o Bairro da Paz à beira da Avenida Paralela, bem mais ao Norte. Como já foi mencionado, nesses espaços superiores concentramse os equipamentos públicos e privados mais importantes, modernos centros de comércio e serviços, grandes equipamentos urbanos (shoppings, multiplex, parques e centros de convenções) e as oportunidade de trabalho e obtenção de renda.

Os setores médios também ocupam essas áreas, assim como o centro tradicional e as áreas mais antigas da cidade. As áreas populares abrigam a população que não tem possibilidades de consumir o espaço da cidade moderna nem da cidade tradicional, alojando-se tipicamente em parcelamentos clandestinos e habitações precariamente construídas no Miolo ou no Subúrbio Ferroviário de Salvador e nos seus municípios vizinhos. Os trabalhadores de subsistência têm uma forte presença nessas áreas e em alguns pequenos interstícios da Orla Atlântica, como se observa pelos Mapas 2 e 3.

${ }^{5}$ É digno de nota que apesar da presença do pólo industrial em Camaçari, não se encontra uma área tipicamente operária em Salvador, nesse município ou nas suas proximidades, o que se deve a várias razões: Quando o Pólo Petroquímico foi instalado, Camaçarí era um pequeno município de base agrária; as novas indústrias absorveram uma mão-de-obra relativamente qualificada, com remunerações superiores à média do mercado local e transporte especial para as fábricas, recrutada em Salvador ou fora da região; e em uma conjuntura ainda marcada pelo autoritarismo, preocupações com a "segurança nacional" e com o "risco de constituição de um novo ABC" também parecem ter levado o governo federal a desestimular uma concentração operária. Mais recentemente, porém, com a instalação de uma grande unidade da Ford nesse município, com trabalhadores que recebem salários bem mais reduzidos que seus antecessores da petroquímica e um estímulo à sua fixação residencial nas proximidades das fábricas, isto começa a se modificar.

${ }^{6}$ O Bairro da Paz se conformou a partir da denominada "Invasão das Malvinas", efetuada na década de 1980, quando esse tipo de ocupação da terra não mais era tolerada na "área nobre" de Salvador. Após uma primeira expulsão seus moradores voltaram e lutaram pela permanência na área, o que terminaram conseguindo principalmente pela conjuntura política da época, marcada pela redemocratização do país (para mais detalhe ver Pereira, 1989). Hoje ele constitui o único enclave de população de baixa renda à beira da Avenida Paralela, com a sua área original "congelada" cercada e vigiada pelo capital imobiliário, que vem implantando o condomínio fechado Alphaville e outros grandes empreendimentos nessa região. 
Mapa 2 - Tipologia socio-espacial - Salvador - 1991

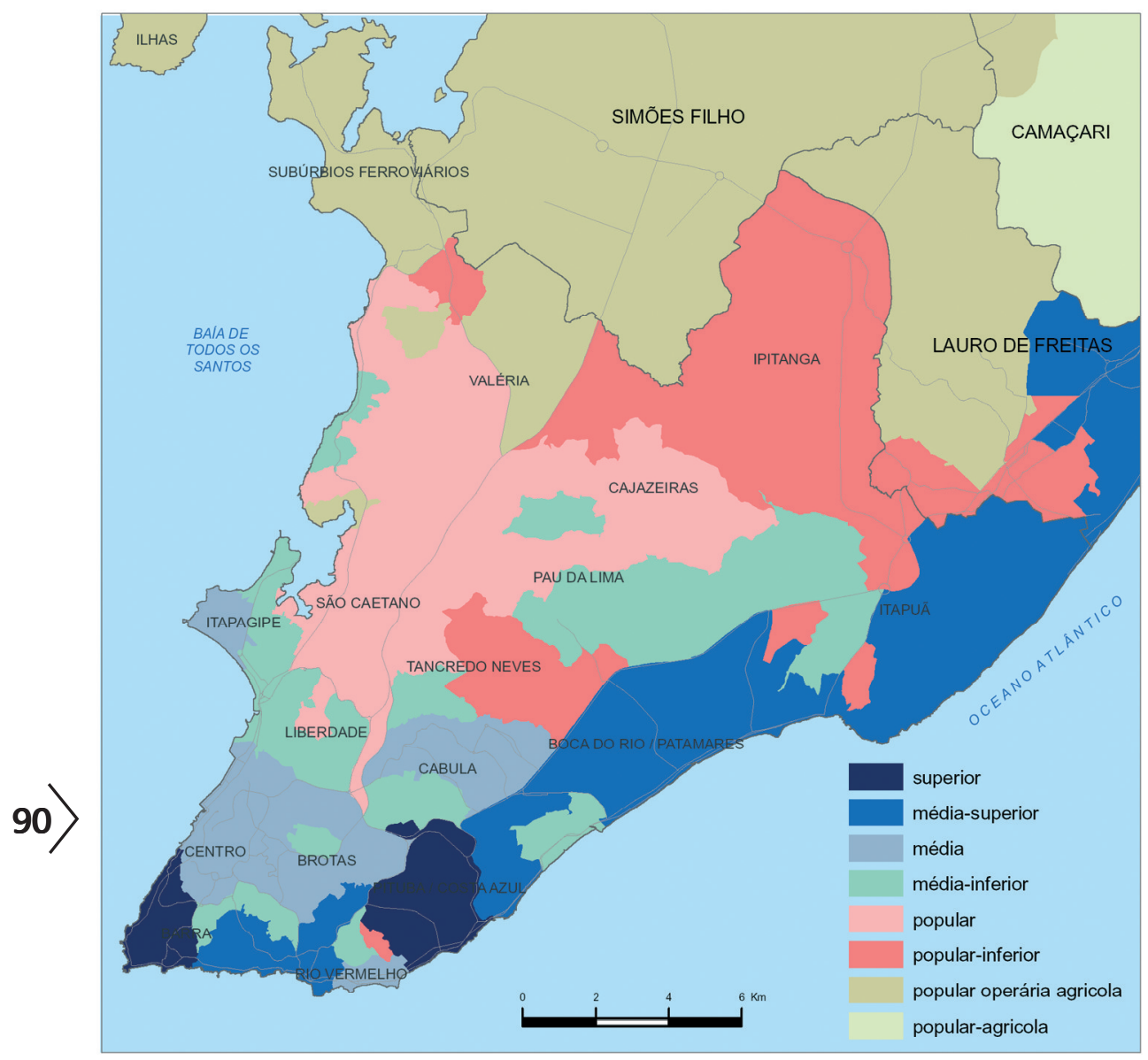

Fonte: IBGE. Censo Demográfico de 1991. Tipologia e mapa elaborados pelos autores.

Como o Mapa 4 deixa claro, os demais municípios da RMS abrigam uma expressiva população agrícola e suas sedes se caracterizam normalmente como áreas de base popular ou média popular. Com exceção de Lauro de Freitas, polarizado entre os loteamentos e condomínios da orla (que atraem empresários, dirigentes, profissionais de nível superior e outras categorias de maior nível de renda, muitos deles trabalhando no pólo de Camaçari ou em Salvador) e os espaços do tipo popular inferior de Itinga e do seu entorno.

Como seria de esperar, há uma estreita articulação entre as características e ocupação dessas diversas áreas e o valor do solo urbano. 0 Mapa 5 ilustra essa diferenciação com os valores praticados pela administração municipal de Salvador para efeitos de cobrança do IPTU, tendo como referência os logradouros. Na classe inical o valor do solo é superior a $\mathrm{R} \$ 100,00$ por metro quadrado; na classe seguinte 
Mapa 3 - Tipologia socio-espacial - Salvador - 2000

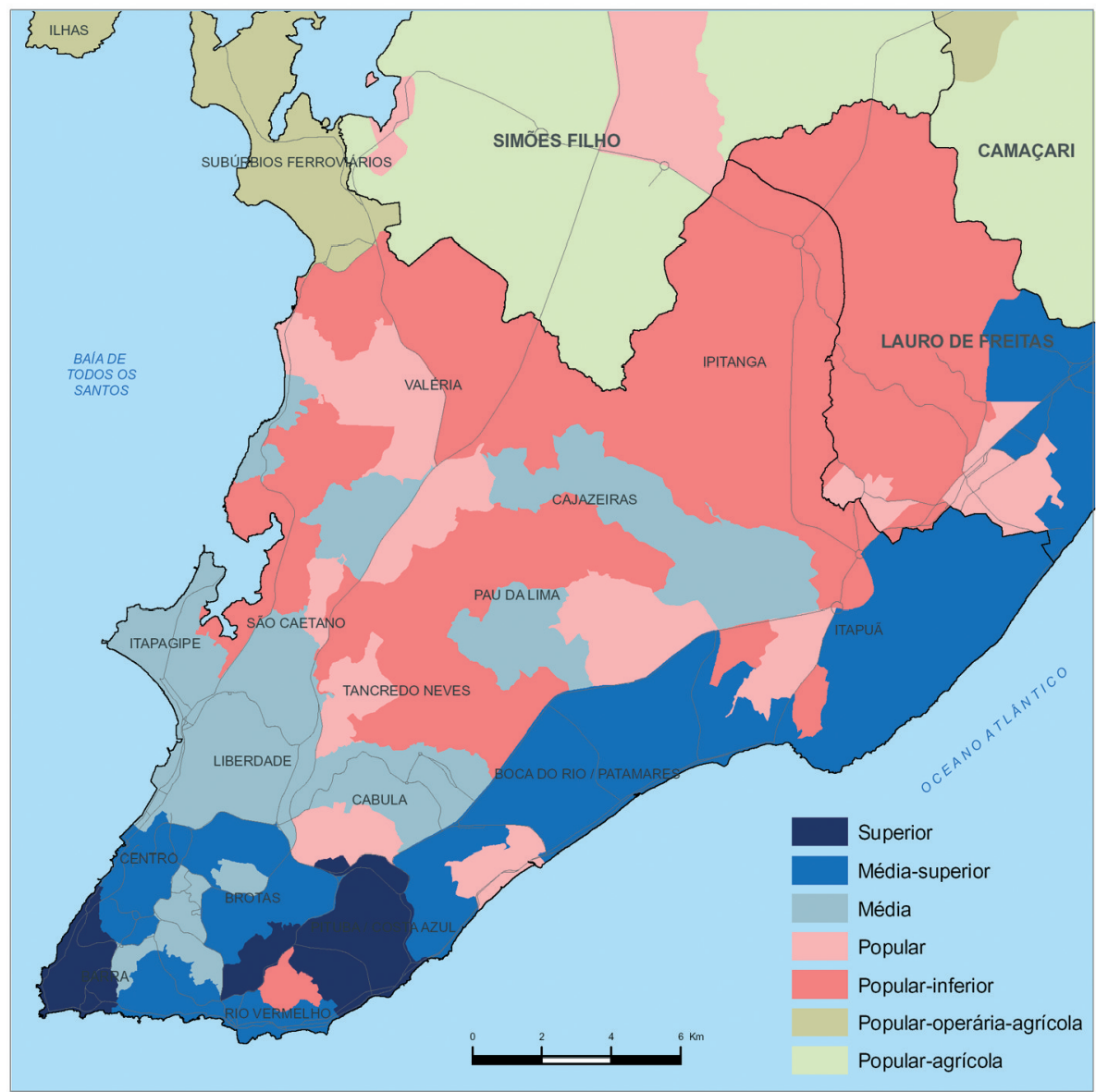

Fonte: IBGE. Censo Demográfico de 2000.Tipologia e mapa elaborados pelos autores.

ele varia de $R \$ 75,00$ a $R \$ 100,00$; na próxima de $R \$ 50,00$ a $R \$ 75,00$; na penúltima de $R \$ 30,00$ a $R \$ 50,00$ e na última ele fica abaixo de $R \$ 30,00 .^{7}$ Fica evidente uma correspondência com a tipologia espacial, com as áreas superiores e médiosuperiores ocupando os espaços onde o solo urbano tem maior valor e as áreas populares ocupando os trechos menos valorizados do território municipal.

A associação existente entre as dimensões socioocupacional e racial constitui um outro aspecto relevante para a análise da segregação. ${ }^{8}$ Como se sabe,

${ }^{7}$ Dados publicados pela Secretaria da Fazenda do Município de Salvador. Esses números não refletem os valores reais e atuais praticados pelo mercado imobiliário, mas são indicativos das diferenças de valor do solo entre os vários espaços.

${ }^{8}$ As relações entre as dimensões social e racial da segregação não são analisadas no presente texto, que constata apenas sua associação. Para essa discussão ver Carvalho; Barreto, 2008. 
Mapa 4 - Tipologia socio-espacial - Região Metropolitana de Salvador - 2000

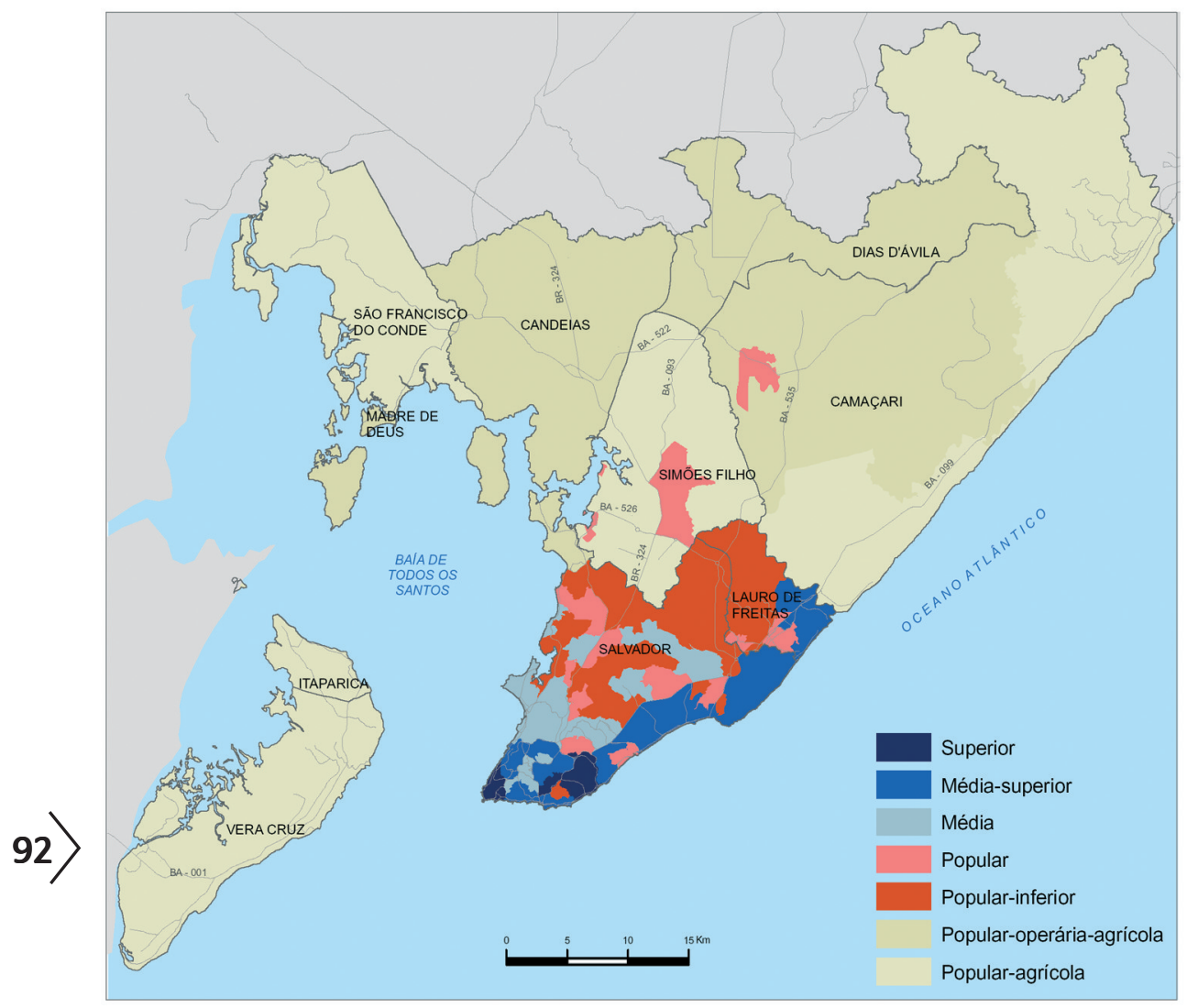

Fonte: IBGE. Censo Demográfico de 2000. Tipologias e Mapa elaborados pelos autores.

em decorrência da sua história, Salvador tem uma grande influência negra e uma população onde $54,8 \%$ se identificaram como pardos e $20,4 \%$ como pretos no Censo de 2000. Secularmente discriminados e com restritas oportunidades de educação, inserção produtiva e ascensão social, pretos e pardos têm ficado, historicamente, na base da pirâmide social.

Observando-se a distribuição das raças pelas categorias ocupacionais utilizadas nesta pesquisa, por exemplo, verifica-se que 3,1\% dos brancos encontravamse entre os dirigentes e grandes empregadores e $15,4 \%$ na categoria dos profissionais de nível superior; $5,7 \%$ eram pequenos empregadores, 37,6\% exerciam ocupações típicas das classes médias (como ocupações técnicas, de supervisão e de escritório), $10,4 \%$ trabalhavam como operários da indústria, $17,0 \%$ no terciário relativamente especializado e 10,2\% como prestadores de serviços não especializados, empregados domésticos, ambulantes e biscateiros, no ano 2000.

No caso dos pardos, a participação entre dirigentes e grandes empregadores restringia-se a $0,8 \%$, entre os profissionais de nível superior a $5,1 \%$, entre os pequenos 
Mapa 5 - Valor do solo urbano para efeitos de pagamento do IPTU - Salvador - 2006

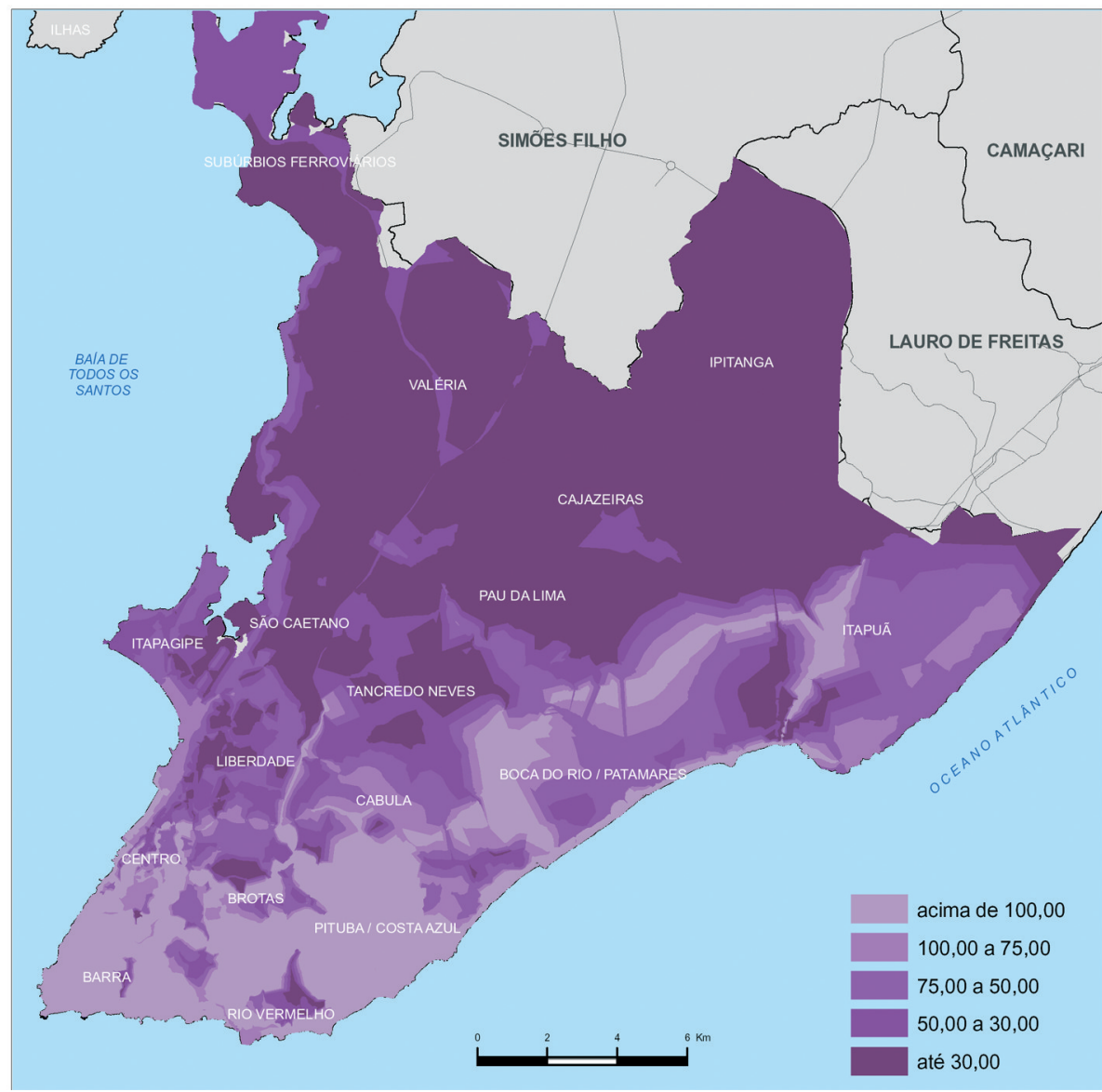

Fonte: Salvador. Prefeitura Municipal/Secretaria da Fazenda. Mapa elaborado por Gilberto Corso Pereira e Silvana Carvalho, para o Relatório do Projeto Vazios Urbanos.

empregadores a 1,7\% e, entre os que desempenhavam ocupações de nível médio, a $28,2 \%$. Já entre os trabalhadores na indústria, seu peso chegava a $19,1 \%$, principalmente em decorrência do desempenho de atividades na construção civil, que absorvia $7,7 \%$ dos ocupados nesse grupo; entre os prestadores de serviços relativamente especializados sua presença chegava a $23,4 \%$ e, entre os prestadores de serviços não especializados, a $21,2 \%$.

A inserção dos que se identificaram como pretos, era bem mais precária: não mais que $0,3 \%$ deles integravam o grupo dos grandes empregadores e dirigentes, $3,5 \%$ o dos profissionais de nível superior e $0,9 \%$ o dos pequenos empregadores; $23,6 \%$ tinham ocupações de nível médio e 21,7\% trabalhavam na indústria, metade dos quais na construção civil; ocupados no terciário relativamente qualificado estavam $23,1 \%$, e, no subproletariado, como prestadores de serviços não especializados, empregados domésticos, ambulantes e biscateiros, $34,1 \%$. 
Como a posição na estrutura social e a apropriação do espaço urbano são estreitamente articuladas, o território metropolitano termina por assumir diferentes "cores". A área central de Salvador (onde ficam bairros como Barris, Graça e Canela) e a faixa da Orla Atlântica que vai de Salvador a Lauro de Freitas, onde se concentram as oportunidades de trabalho, a maior parte dos equipamentos urbanos e os espaços classificados como superiores e como médio superiores constituem as áreas residenciais privilegiadas da parcela branca da população. Ela está especialmente sobre representada nos espaços superiores da Barra, Graça, Campo Grande/Canela e Pituba, onde os brancos chegam a $69,1 \%, 69,7 \%, 68,5 \%$ e $65,7 \%$, enquanto os pretos não passam de $5,9 \%, 4,4 \%, 7,0 \%$ e $5,0 \%$. Já os pretos e pardos se abrigam predominantemente em áreas do tipo popular ou popular-inferior do Miolo e do Subúrbio (como Cajazeiras, Fazenda Grande, Tancredo Neves, Coutos, Plataforma, Periperi, Lobato ou Paripe), de uns poucos enclaves do centro e da orla (Engenho Velho da Federação, Alto das Pombas, Liberdade, Nordeste de Amaralina e Bairro da Paz, por exemplo), muitas vezes em sítios acidentados e desfavoráveis, ${ }^{9}$ assim como nos demais municípios da RMS. A tabela que se segue ilustra essa distribuição.

Tabela 1 - Composição racial por tipo de áreas - Salvador - 2000

\begin{tabular}{|c|c|c|c|c|c|}
\hline \multirow{2}{*}{ Tipos de Áreas } & \multicolumn{5}{|c|}{ Composição Racial (em \%) } \\
\hline & Brancos & Pardos & Pretos & Outros & Total \\
\hline Superior & 64,8 & 27,5 & 6,5 & 1,21 & 100 \\
\hline Média superior & 40,0 & 44,3 & 14,3 & 1,39 & 100 \\
\hline Média & 18,9 & 57,7 & 21,7 & 1,64 & 100 \\
\hline Popular & 18,3 & 56,2 & 23,6 & 1,89 & 100 \\
\hline Popular inferior & 13,7 & 60,9 & 23,3 & 2,09 & 100 \\
\hline Popular/operário/agrícola & 12,6 & 64,8 & 20,2 & 2,33 & 100 \\
\hline
\end{tabular}

Fonte: IBGE, Censo Demográfico, 2000. Cf. Carvalho e Barreto, 2008.

Ela também fica patente através dos Mapas 6, 7 e 8, que mostram a distribuição dos brancos, pardos e pretos no território, assim como dos Mapas 9 e 10, que sintetizam a concentração espacial desses segmentos; ou seja, as AEDs onde os mesmos estão acima da sua média na RMS.

As articulações existentes entre as condições sócio-econômicas, a localização da moradia e as diferenças raciais constituem uma questão que precisa ser analisada mais profundamente e enfrentada, uma vez que o território também interfere sobre os constrangimentos e possibilidades que produzem e reproduzem a pobreza e as desigualdades, como será visto em capítulo a seguir.

\footnotetext{
${ }^{9}$ Cajazeiras, por exemplo, começou a ser ocupada por conjuntos habitacionais para a "classe média baixa" implantados nas suas cumeadas na fase áurea do $\mathrm{BNH}$, sendo a maior parte da sua área considerada como "não edificável" por sua elevada declividade. Ainda assim o bairro se expandiu com a ocupação dessas escarpas por famílias pobres e geralmente negras.
} 
Mapa 6 - Distribuição residencial dos brancos - Salvador - 2000

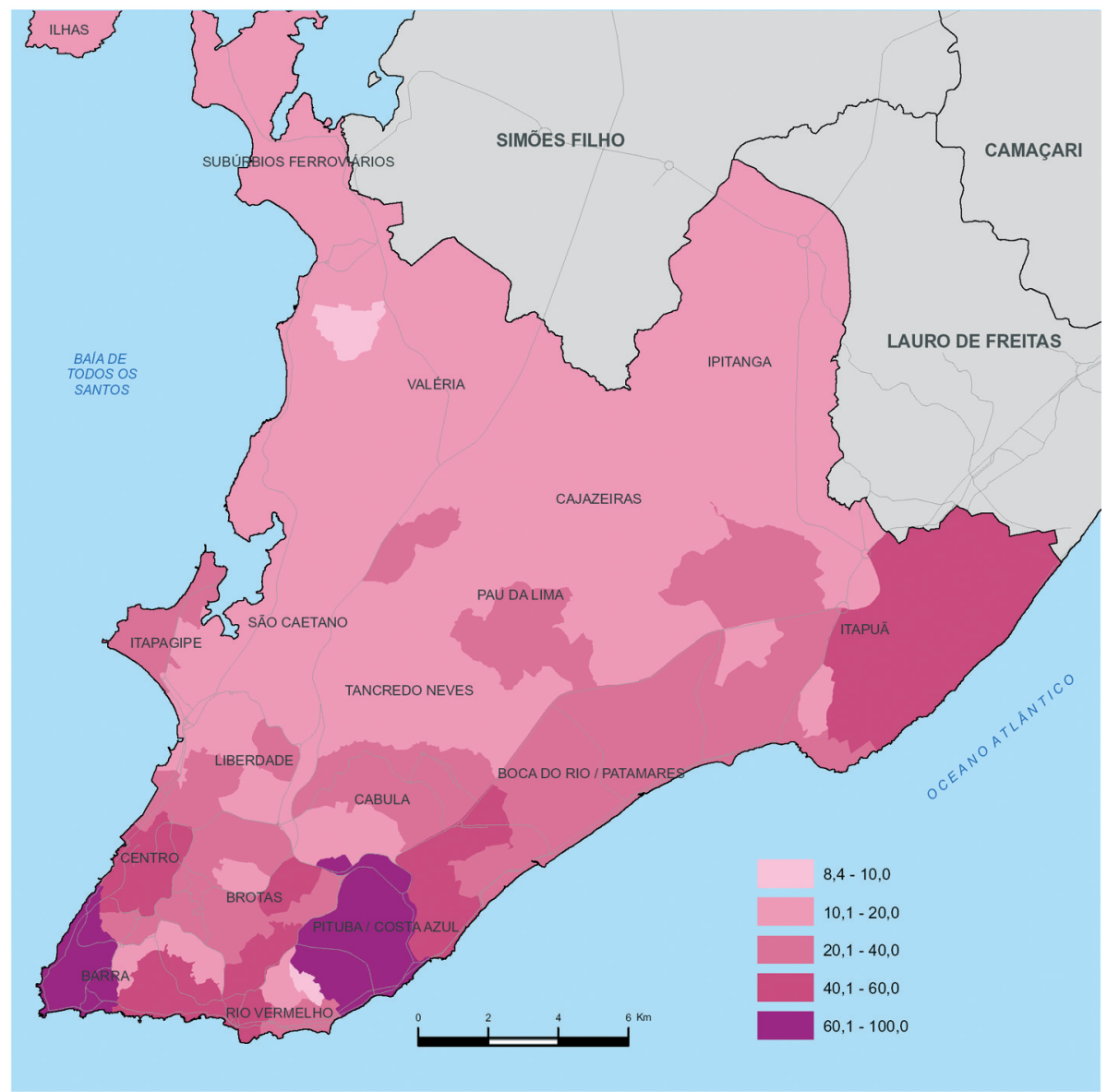

Fonte: IBGE. Censo Demográfico 2000. Mapa elaborado pelos autores.

\section{AS TRANSFORMAÇÕES DOS ÚLTIMOS ANOS}

Salvador chegou ao século XXI com os territórios do pólo e do município vizinho de Lauro de Freitas (com o qual se conurba) já totalmente urbanizados e a metrópole se espraiando em direção ao Norte, com a ocupação dos últimos espaços da velha capital e seu transbordamento para as bordas e para os municípios de Lauro de Freitas e Simões Filho, mantendo basicamente os mesmos padrões de apropriação do território e de segregação analisados nas páginas anteriores. Ao lado dessa persistência; porém, ocorrem transformações similares às constatadas em outras metrópoles brasileiras.

Com o esvaziamento e a deterioração do velho centro, o novo coração econômico da metrópole, que começou a se desenvolver com a implantação do Shopping Iguatemi, do primeiro hipermercado e de alguns dos primeiros prédios de 
Mapa 7 - Distribuição residencial dos pardos - Salvador - 2000

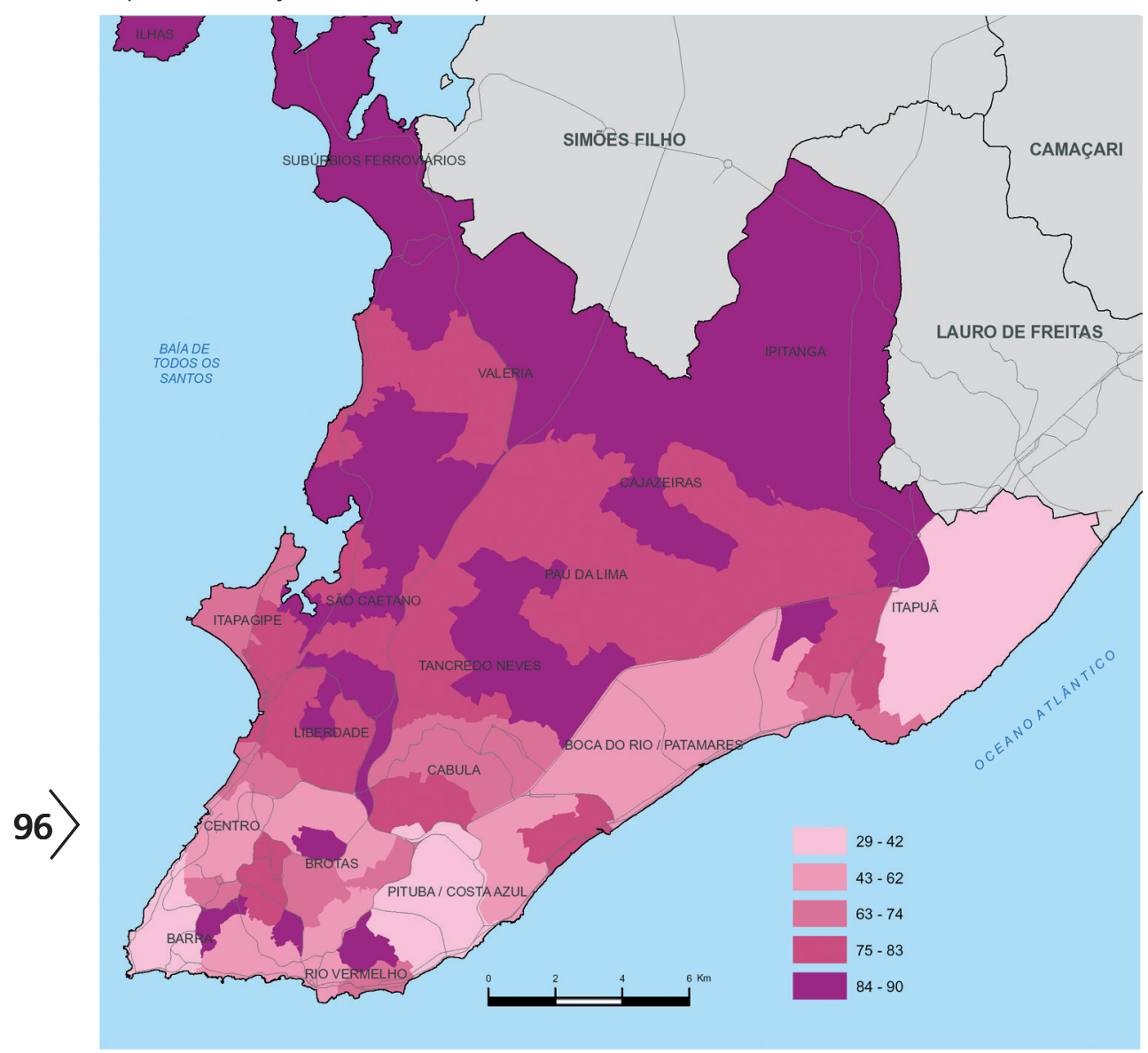

Fonte: IBGE. Censo Demográfico 2000. Mapa elaborado pelos autores.

escritório, e se consolidou nos anos 90 , continua a se expandir em torno do eixo Avenida Tancredo Neves/Paralela. Agora com a multiplicação de maiores, mais modernos e luxuosos shoppings, centros de negócios e serviços, centros médicos, "edifícios inteligentes" e outros grandes equipamentos, reforçando a valorização imobiliária do eixo urbano do litoral norte.

Confirmando a tendência a um maior isolamento e auto-segregação das elites, ressaltada por autores como Préteicelle $(2003,2006)$, as áreas superiores de Salvador permaneceram como tal, com o acréscimo de mais uma delas (o Horto Florestal) e uma crescente elitização e verticalização. Se no conjunto dessas áreas as unidades com renda domiciliar superior a vinte salários mínimos representavam 41,3\% em 1991, em 2000 esse número subiu para 60,9\%. Na Vitória, Graça e Barra, áreas tradicionais da população de alta renda, velhas mansões estão sendo substituídas por elevados e luxuosos condomínios verticais fechados, que oferecem 
Mapa 8 - Distribuição residencial dos pretos - Salvador - 2000

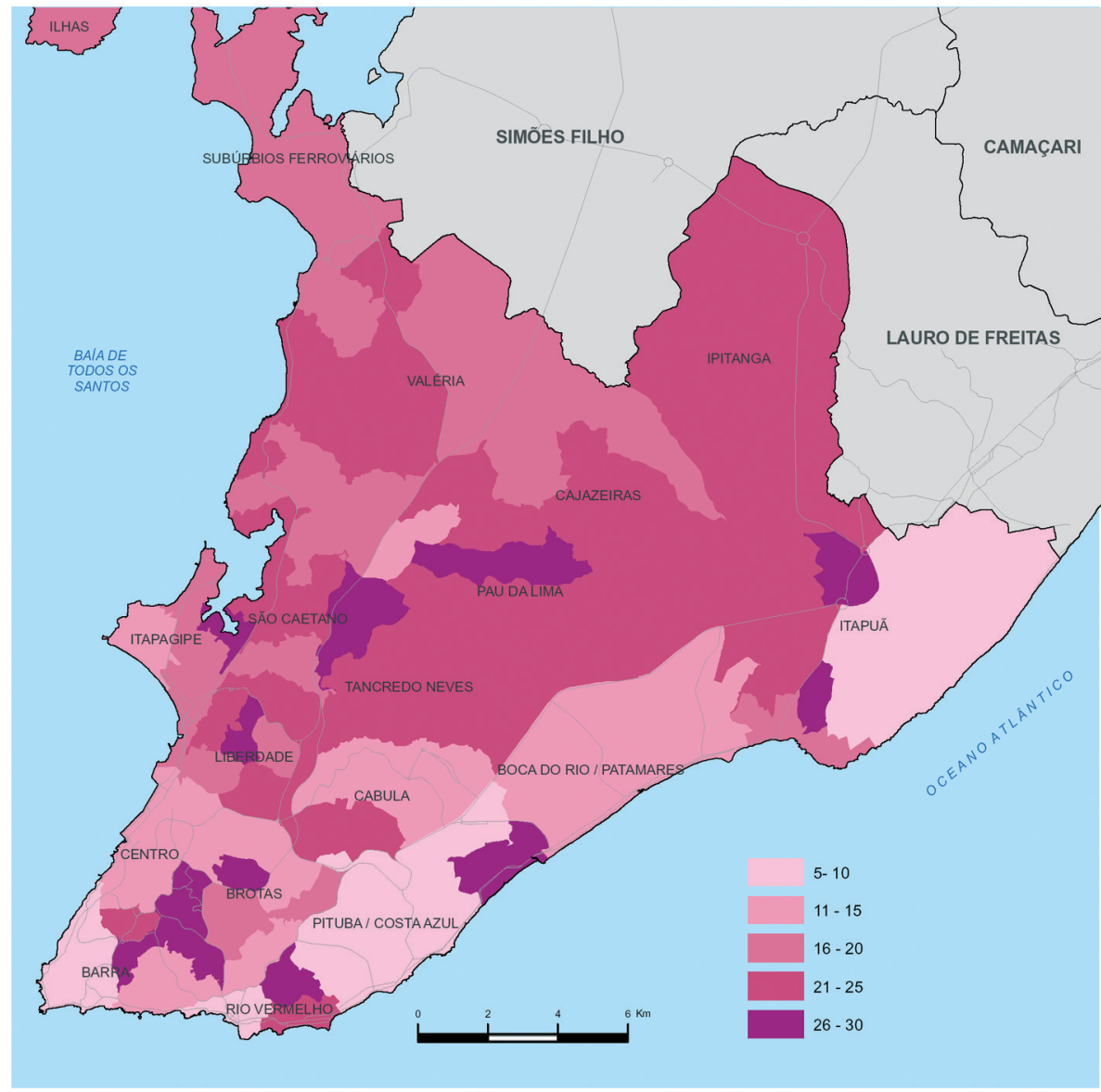

Fonte: IBGE. Censo Demográfico 2000. Mapa elaborado pelos autores.

segurança, lazer e várias comodidades aos seus moradores, permitindo-lhes permanecer um maior tempo em espaços exclusivos e protegidos da violência e de outros problemas urbanos. Na nova área de tipo superior da cidade esse padrão de moradia também é dominante. ${ }^{10}$

${ }^{10}$ No Brasil e em outros países, onde a segurança se converteu de atributo público indivisível para uma proteção individual ou de grupo ligado ao poder aquisitivo de cada um, a violência e o medo da violência tem levado à fortificação física do espaço, transformando-se em um dos princípios organizadores das cidades contemporâneas. Como assinala Amendola (2000) com a decadência dos critérios reguladores da distribuição territorial da violência e a afirmação, em seu lugar, do princípio da ubiqüidade e casualidade absoluta e a mescla da violência real com a reconstruída pela mídia e pelo imaginário, o cidadão aterrorizado busca viver em uma bolha protetora no interior da cidade, que deseja igualmente protegida, permanecendo o mais possivel no interior de áreas fortificadas e blindando tanto a casa como a própria vida. 
Mapa 9 - Concentração de brancos, pardos e pretos - Salvador - 2000

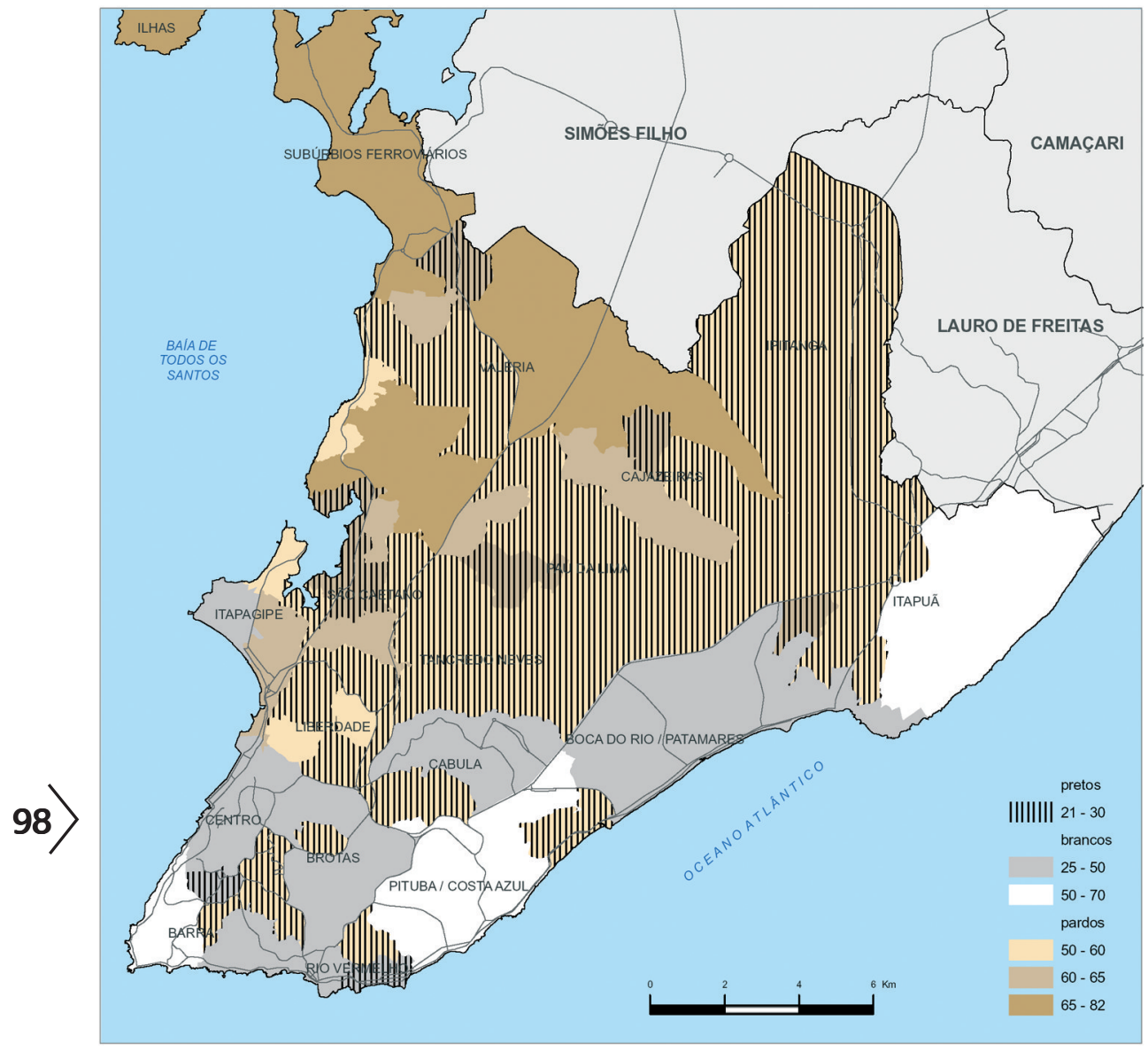

Fonte: IBGE. Censo Demográfico 2000. Mapa elaborado pelos autores.

Nos demais espaços a evolução vem sendo mais complexa. ${ }^{11}$ Concentradas na orla de Salvador, na Avenida Paralela e em Lauro de Freitas, onde os condomínios horizontais fechados se multiplicam, as áreas antes classificadas como média-superior preservaram essa condição. A elas se juntaram algumas outras, localizadas em antigos bairros próximos ao centro tradicional, que passaram de média para média-superior.

Transformações mais diversificadas atingiram as áreas de menor nível

${ }^{11}$ Analisando a estrutura urbana da metrópole parisiense em um estudo publicado mais recentemente, Préteicelle (2006) constatou que as categorias superiores são as mais segregadas e essa segregação vem se acentuando; nas demais áreas há uma evolução social diversificada e uma mistura social mais freqüente e os espaços populares vêm tendo o tecido social ameaçado pela precarização e pelo desemprego.

Resguardadas as enormes diferenças (como, por exemplo, a ausência de espaços tipicamente operários) as transformações constatadas em Salvador apresentam uma certa semelhança com essa evolução. 


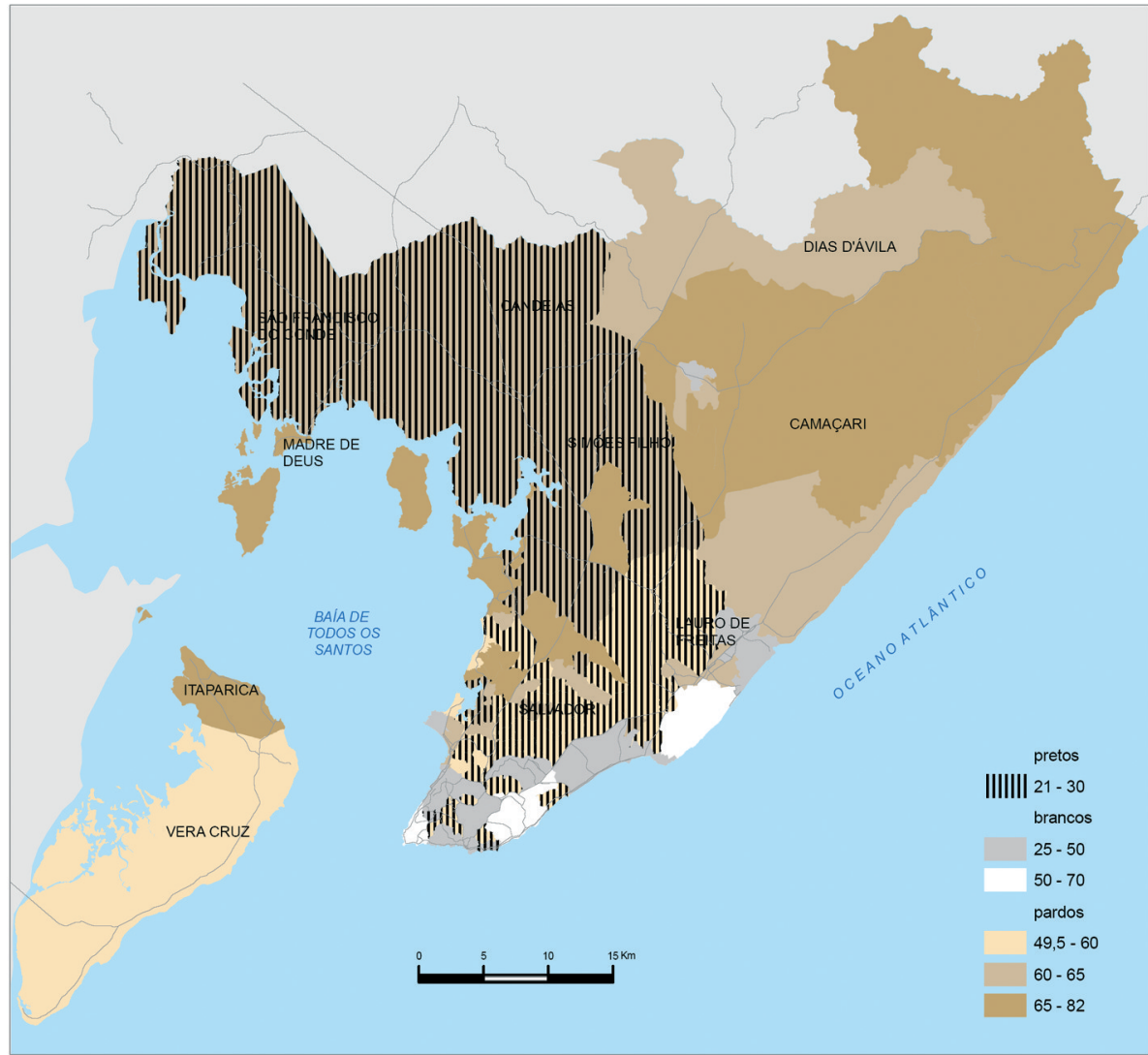

Fonte: IBGE. Censo Demográfico 2000. Mapa elaborado pelos autores.

social. Alguns trechos de Cajazeiras (onde passam as principais vias de acesso ao Miolo, se concentram os antigos conjuntos habitacionais e houve uma certa expansão do comércio e dos serviços), a Liberdade e adjacências e alguns trechos da Cidade Baixa, classificados em 1991 como média-inferior ou como popular, parecem ter atraído moradores de um nível social um pouco mais elevado, sendo categorizados como de tipo médio em 2000. Em outras áreas populares, porém, a exemplo de Plataforma, Mata Escura, Pau da Lima ou certos segmentos de Cajazeiras ampliou-se o número de prestadores de serviços não especializados, trabalhadores domésticos, ambulantes, biscateiros e desempregados. Essa evolução negativa também foi experimentada pelos enclaves de menor renda da Orla. Por isso mesmo o Nordeste de Amaralina passou do tipo médio popular para popular-inferior, a Boca do Rio de médio popular para popular e o Bairro da Paz se manteve estável como popular inferior em 1991 e 2000, o tipo mais baixo da hierarquia expressa pela tipologia sócioespacial proposta (ver Mapa 11). 
Mapa 11 - Evolução da tipologia socioespacial - RMS 1991-2000

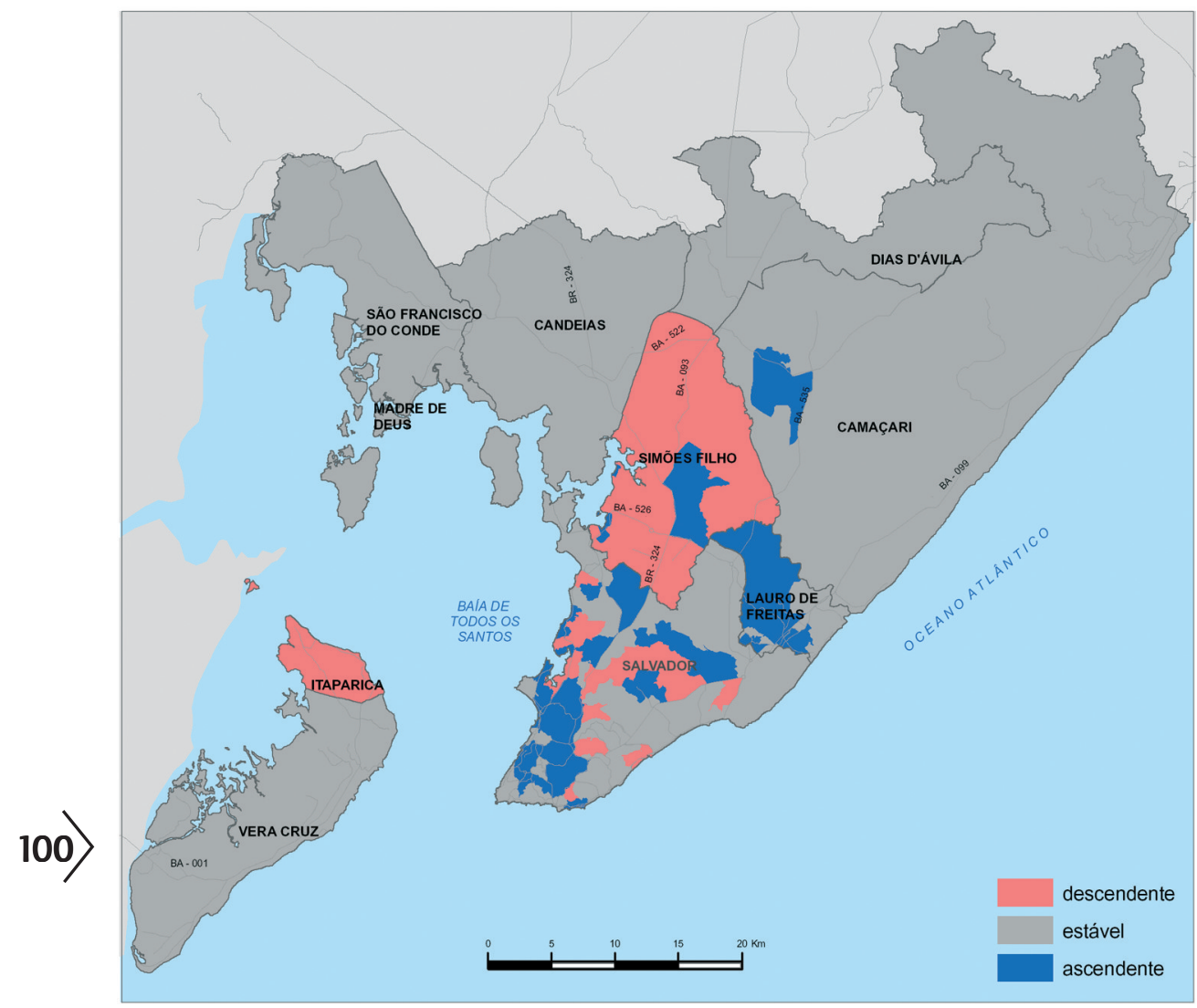

Fonte: IBGE. Censo Demográfico 2000. Mapa elaborado pelos autores.

Sem transformações econômicas e sociais mais expressivas, os demais municípios da RMS mantém fundamentalmente o mesmo perfil de moradores, persistindo como territórios de base agrícola ou popular, com a já mencionada exceção de Lauro de Freitas, que dá continuidade tanto à "área nobre" do pólo metropolitano na sua orla quanto aos territórios do tipo popular inferior do outro lado da estrada do Coco. Mas com a contratação de novos trabalhadores pelas indústrias instaladas mais recentemente no pólo e os estímulos para a sua fixação em Camaçari, é possível que a mais longo prazo venha a se constituir um núcleo de tipo operário nesse município. As áreas do tipo popular-operário-agrícola que tem grande expressão espacial nos municípios de Candeias, São Francisco do Conde e Camaçari tem uma participação relativamente significativa, na sua composição social, de operários da construção civil e trabalhadores da indústria moderna, como do pólo petroquímico e da Petrobras, por exemplo.

Analisando a evolução da participação das categorias ocupacionais 
inferiores e superiores nas diversas áreas de ponderação, e cruzando esses dados com a evolução da densidade demográfica também por área (representada no Mapa 12), podem ser identificadas aquelas que mais tem recebido os contingentes populacionais que estão nos extremos da hierarquia social. Como áreas de expansão dos grupos de menor renda destacam-se o Alto de Santa Terezinha e a Boa Vista do Lobato, no Subúrbio Ferroviário, as áreas de Mata Escura e Cajazeiras, no Miolo, assim como as de Valéria e Areia Branca, nos limites de Salvador com Simões Filho e Lauro de Freitas, evidenciando como a tendência à concentração dos pobres na periferia mais distante e desequipada e nos municípios vizinhos ao pólo metropolitano tende a se acentuar.

No outro extremo estão o Horto Florestal e Patamares/Pituaçu, como as áreas de expansão das categorias superiores, com destaque para a primeira, certamente a área mais elitizada da metrópole. Vilas do Atlântico, em Lauro de Freitas, se destaca como área de expansão das categorias que definem o tipo médio-superior. $\mathrm{Na}$ Pituba, ainda que não tenha havido um aumento significativo da densidade demográfica, verifica-se um aumento claro da participação das categorias superiores, indicando uma maior elitização.

Em uma leitura um tanto esquemática, pode-se dizer que Salvador é uma metrópole que comporta uma cidade "tradicional", uma cidade "moderna" e uma cidade "precária". Na cidade tradicional o tecido urbano é compacto, relativamente homogêneo, e não há um crescimento expressivo da população, que é composta predominantemente pelos setores médios. É a cidade que se constituiu a partir do centro antigo e de seu entorno. Já na cidade moderna o tecido urbano está se modificando com a produção de novas habitações e centros de consumo e serviços, construídas dentro de padrões arquitetônicos e urbanísticos elevados, com avançado processo de verticalização nas áreas mais densas e/ou próximas ao centro. Ocupando, a partir do centro, as áreas próximas à orla atlântica e crescendo em direção ao litoral norte, ela é habitada basicamente pelas camadas mais altas da pirâmide social.

Finalmente, na cidade precária, ocupada predominantemente pelos setores populares, o tecido urbano se caracteriza pela dispersão e pela contínua expansão com o acréscimo de habitações precárias, em grande parte auto-construídas sem obedecer a padrões arquitetônicos e urbanísticos, com ocupação horizontal, excetuando as áreas próximas às vias de maior circulação e as áreas mais consolidadas em termos de ocupação do solo, onde estão em curso processos de verticalização, com grande adensamento, de padrão um pouco melhor.

Como foi visto, a cidade moderna e a cidade precária, não são totalmente homogêneas em termos de tecido urbano, equipamentos e habitações. Na cidade moderna existem ilhas de precariedade e a cidade precária contém ilhas de relativa prosperidade. Ambas se expandem para além do município de Salvador, a primeira seguindo o vetor da orla Atlântica na direção dos municípios de Lauro de Freitas e Camaçari, já se expandindo, inclusive, além dos limites institucionais da RMS, em um padrão de urbanização que Reis (2006) denominou "urbanização dispersa"; a segunda 
em direção a Simões Filho e ocupando a franja interna de Lauro de Freitas, município totalmente integrado a Salvador, tanto no lado "moderno" quanto no "precário". Os demais municípios continuam sem grandes modificações, sendo importante relevar aqui a distância cada vez maior que vai se estabelecendo entre a sede e a orla dos municípios litorâneos da RMS, com estes espaços se conectando diretamente à Salvador, o município pólo e tendo cada vez menos interação com suas sedes municipais, caso principalmente de Camaçari, mas também de Mata de São João que até 2007 não fazia parte da RM institucional.

Constatada em outras metrópoles do Brasil e da América Latina, essa tendência à suburbanização e à ocupação das bordas metropolitanas, assim como 0 decréscimo demográfico do centro tradicional, podem ser vistas através do Mapa 12. Vale ressaltar que as divisões e fenômenos em apreço também passaram a ser estimuladas por alguns novos processos, como o crescimento do que atualmente está sendo denominado como turismo-imobiliário nos espaços metropolitanos da orla

Mapa 12 - Evolução percentual da densidade demográfica por AEDS - RMS 1991-2000

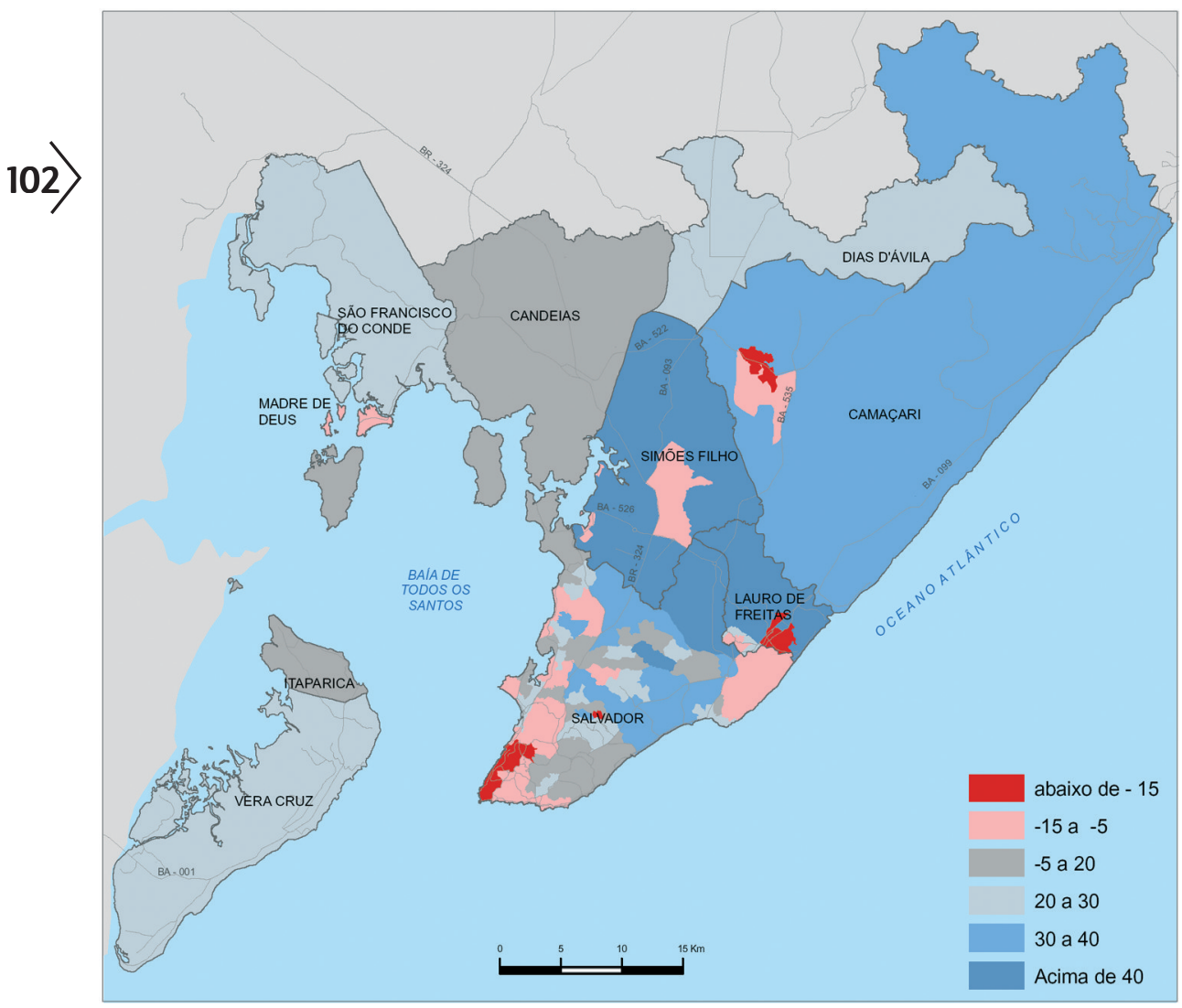

Fonte: IBGE. Censos Demográficos de 1991 e 2000. Mapa elaborado pelos autores. 
atlântica, com a contínua implantação de equipamentos e serviços de consumo, cultura e lazer, elementos que agora se somam ao surgimento de um segmento imobiliário de segunda residência para europeus.

Com exceção do turismo-imobiliário, não se pode dizer que as mudanças assinaladas guardem uma relação mais direta com a dinâmica da globalização. Como o caso de Salvador deixa patente, no processo de urbanização e desenvolvimento brasileiro as desigualdades espaciais têm uma longa trajetória e um caráter extremado, com uma contribuição muito significativa da intervenção estatal. Há mais de duas décadas Kowarick (1979) já chamava a atenção para 0 que denominou como "espoliação urbana"; ou seja, para os mecanismos pelos quais o poder público aumentava a concentração de riqueza e de renda dos grupos dominantes através da distribuição desigual de investimentos geradores do bem estar social urbano, tolerando, simultaneamente, as práticas de especulação imobiliária através das quais determinados segmentos se apropriavam de uma maneira improdutiva de parte expressiva do excedente econômico, e viabilizando um rebaixamento do custo da reprodução da força de trabalho apoiado em salários que podiam ser constantemente deprimidos.

A constituição de poderosos circuitos de acumulação fundados na escassez relativa do solo urbano também foi destacado por Lessa (s.d), ressaltando como a internacionalização da economia no processo de industrialização e desenvolvimento brasileiro foi ancorado por uma "sagrada aliança", que garantiu uma complementaridade de interesses e uma solidariedade entre os capitais internacionalizados e os capitais nacionais, dominantes em órbitas não industriais. Como fiador dessa aliança, o Estado velou para que houvesse uma divisão de órbitas de atuação e uma distribuição horizontal do excedente, de forma a assegurar uma equalização da rentabilidade dos investimentos realizados nas diferentes órbitas, reservando o setor imobiliário para o capital nacional, adotando uma postura permissiva frente aos movimentos especulativos e tomando outras iniciativas que submeteram a organização do espaço urbano aos interesses e demandas do capital imobiliário. E se os tempos, os atores e os mecanismos de espoliação urbana se transformaram, o poder do capital imobiliário permanece e até se fortalece nos dias atuais, como bem demonstra a recente e polêmica revisão do Plano Diretor de Desenvolvimento Urbano de Salvador, acontecida numa madrugada do final do ano de 2007, centrada na liberação do gabarito da orla e em outros interesses desse capital, gerando uma sobre-valorização de terrenos já valorizados que grandes proprietários mantinham ociosos, pouco se preocupando com o conjunto e com o "resto" da cidade. É preciso considerar também que em metrópoles regionais de periferia, como Salvador, a dinâmica da globalização tem impactos de caráter mais restritos e indiretos, associados basicamente aos efeitos da reestruturação produtiva e da abertura econômica sobre o desenvolvimento e sobre as desigualdades regionais, aos novos padrões de intervenção estatal, às novas formas de produção e distribuição da riqueza e às transformações do mercado de trabalho. 
Essas transformações foram especialmente deletérias no caso de Salvador, com uma enorme precarização das ocupações, um desemprego de massa persistente e crônico e um empobrecimento de amplos contingentes populacionais, atingindo notadamente, como seria de esperar, os bairros populares. Conforme os dados do Censo de $2000^{12}$ em 33,5\% dos domicílios das áreas de tipo popular em Salvador seus moradores tinham uma renda domiciliar per capita de até meio salário mínimo, que os colocava em uma situação de pobreza, e 14,3\% de até meio salário mínimo, o que correspondia a uma situação de indigência. Em $5,4 \%$ do total de domicílios os moradores não possuíam nenhum rendimento. Nas áreas do tipo popular inferior esse números chegavam a $44,3 \%, 19,9 \%$ e 6,4\%, respectivamente.

Em bairros como Plataforma, Mata Escura, Pau da Lima ou Nordeste de Amaralina, que entre 1991 e 2000 passaram para o tipo popular inferior, a proporção de domicílios com moradores pobres era de $45,1 \%, 39 \%, 40 \%$ e $42 \%$ e a de indigentes de $23,9 \%, 17,8 \%, 17,3 \%$ e $18,4 \%$. Ademais, entre as pessoas de referência do domicílio, $47,3 \%, 37,29 \%, 35,1 \%$ e $28,2 \%$ não exerciam qualquer trabalho remunerado e 0 número de jovens que não trabalhavam nem estudavam era particularmente elevado.

Sumarizando as conclusões, constata-se a consolidação do padrão periférico de apropriação e utilização do território de Salvador que se conformou a partir de 1960, paralelamente ao aprofundamento de determinadas tendências anteriores e a algumas novas transformações. $O$ esvaziamento demográfico e econômico do centro tradicional tem se acentuado, com o declínio ou a própria deterioração de diversas áreas, em que pese a existência de iniciativas ou propostas para a revitalização de algumas delas, a exemplo do Pelourinho ou do antigo Comércio. Atendendo a demandas de setores econômicos de ponta e das camadas de alta renda, a cidade "moderna" vem se expandindo e diversificando na orla e no novo coração econômico da metrópole, com a multiplicação de equipamentos de grande impacto na dinâmica e imagem metropolitana, a exemplo dos já mencionados shoppings centers, edifícios corporativos e grandes hotéis. A proliferação de condomínios fechados, o incremento do turismo e os empreendimentos imobiliários a ele associados (incluindo, agora, a perspectiva da oferta de uma segunda residência nos trópicos para europeus) tem contribuído para espraiamento desses equipamentos para o litoral de Camaçari e para além dos próprios limites institucionais da região metropolitana, que no início de 2008 incorporou os municípios de São Sebastião do Passé e Mata de São João.

Em suas grandes linhas o padrão de segregação se mantém, com a acentuação das diferenças e das desigualdades entre o Centro, a Orla, o Miolo e 0 Subúrbio, entre a cidade "tradicional", a cidade "moderna" e a cidade "precária". A dinâmica dos espaços menores, porém, é bem mais complexa e heterogênea. Com a proliferação de condomínios verticais ou horizontais fechados e protegidos,

\footnotetext{
${ }^{12}$ Em decorrência de problemas de comparabilidade entre os Censos de 1991 e 2000, não foi possível analisar a evolução da renda nesse período.
} 
nas áreas superiores e médio-superiores a auto-segregação das camadas altas e médias vem se acentuando. As áreas ocupadas principalmente pelas camadas médias tendem a se manter como tal, enquanto os espaços de caráter popular tem uma evolução diferenciada. Mais centrais e melhor equipados, alguns deles vem atraindo outro tipo de moradores e diversificando a sua ocupação. Outros vem sendo particularmente afetados pelos problemas ocupacionais, o desemprego, a expansão territorializada do tráfico de drogas e a superposição de carências, com uma expressiva deterioração das suas condições e o crescimento da anomia, da conflitividade e da violência. $E$ como os pobres vem sendo empurrados para áreas cada vez mais distantes e desequipadas, a "urbanização dispersa" vem se acentuando e levando a cidade precária além dos limites de Salvador, para os municípios vizinhos.

Assim, as transformações do presente vem atualizando velhos processos, exacerbando as desigualdades sociais e espaciais e a perversidade da segregação, ainda que isto se deva menos a necessidades e determinantes intrínsecos da globalização que aos interesses e às opções das elites nacionais e regionais, que vem orientando a articulação do Brasil ao capitalismo mundializado e 0 desenvolvimento das regiões metropolitanas.

\section{REFERÊNCIAS}

ALMEIDA, Paulo Henrique. A economia de Salvador e a formação de sua Região Metropolitana. In: CARVALHO, Inaiá M.M.; PEREIRA, Gilberto Corso (Org.) Como anda Salvador. Salvador: Edufba, 2006.

; DAMASCENO, Luciano. Perfil sócio econômico do trabalhador informal em Salvador - 2005. Relatório parcial de pesquisa. Salvador: 2005.

AMENDOLA, Giandomenico. La ciudad postmoderna. Madrid: Celeste Ediciones, 2000.

BORGES, Ângela Maria Carvalho. Desestruturação do mercado de trabalho e vulnerabilidade social: a Região Metropolitana de Salvador na década de 90. 2003. Tese (Doutorado) - Curso de em Ciências Sociais da Faculdade de Filosofia e Ciências Humanas da UFBA. Salvador, 2003.

BORJA, Jordi; CASTELS, Manuel. Local e global. La gestión de las ciudades en la era de la información. Madrid: Taurus, 1997.

BORSDOR, Axel. Como modelar el desarrollo y la dinâmica de la ciudad latinoamericana. EURE, Santiago do Chile, v.23, n.86, 2003.

BOURDIEU, Pierre (Coord.) Efeitos de lugar. In: A miséria do mundo. 3.ed. Petrópolis: Vozes, 1999. p.159-214.

. O poder simbólico. Lisboa: DIFEL. Rio de Janeiro: Ed. Bertrand Brasil, 1989.

BRANDÃO, Maria D. de A. O último dia da criação: mercado, propriedade e uso do solo em Salvador. In: VALLADARES, Lícia do P. (Org.) Habitação em questão. Rio de Janeiro: Zahar, 1981.

CALDEIRA, Teresa P. do R. Cidade dos muros: crime, segregação e cidadania em São Paulo. São Paulo: Ed. 34/EDUSP, 2000. 
CARVALHO, Inaiá M. M. de; CODES, Ana Luisa. Condições de ocupação, pobreza e desigualdades. In: ; PEREIRA, Gilberto Corso (Org.) Como anda Salvador. Salvador: EDUFBA, 2006. p. 109-135.

; BARRETO, V. S. Segregação residencial, condição social e raça em Salvador. Caderno Metrópole.

São Paulo: EDUC. n. 18, $2^{\circ}$ semestre de 2007, p. 251-273.

;PEREIRA, Gilberto Corso. Segregação sócioespacial e dinâmica metropolitana. In:

(Org.) Como anda Salvador. Salvador: EDUFBA, 2006. p.83-108.

; ALMEIDA, Paulo Henrique; AZEVÊDO, José Sérgio G. Dinâmica metropolitana e estrutura social em Salvador. Tempo Social: revista de sociologia da USP, São Paulo, v. 13, n.2, p.89-114, 2001.

; SOUZA, Guaraci A. A. de. A produção não capitalista de Salvador. In: ; FARIA, Vilmar (Org.) Bahia de Todos os Pobres. São Paulo: CEBRAP, 1980.

DIAS, Patrícia Chame. A construção da segregação residencial em Lauro de Freitas (BA): estudo das características de implicações do processo. 2005. Dissertação (Mestrado em Geografia) - Instituto de Geociências da Universidade Federal da Bahia, Salvador, 2005.

DUHAU, Emílio. As novas formas de divisão social do espaço nas metrópoles latino americanas: uma visão a partir da cidade do México. Caderno $\mathrm{CRH}$ : revista do Centro de Recursos Humanos da UFBA, Salvador, v.18, n.45, set./dez., 2005.

FRANCO, Ângela; SANTOS, Elizabeth; GABRIELLI, Lívia. Salvador dos novos horizontes. Força de Trabalho e Emprego, Salvador, v.5, n.2, p.21-29, maio/ago., 1998.

HUCHZERMEYER, Marie. Subsídios habitacionais e segregação urbana: uma reflexão sobre o caso da África do Sul. Espaço \& Debates: revista de Estudos Regionais e Urbanos, São Paulo, v.24, n.45, p.4759, jan./jun., 2004.

JANOSCHKA, Michael. El nuevo modelo de la ciudad latinoamericana: fragmentacion y privatizacion. EURE, Santiago do Chile, v.28, n.85, 2002.

KATZMAN, Rubem; WORMALD, Guilhermo (Coord.) Trabajo y ciudadania. Los cambiantes rostros de la integracion y exclusion social en cuatro areas metropolitanas de America Latina. Santiago do Chile: 2002. KOWARICK, Lúcio. A espoliação urbana. Rio de Janeiro: Paz e Terra, 1979.

LESSA, Carlos. Palestra sobre desenvolvimento urbano proferida na Secretaria de Planejamento e Tecnologia do Estado da Bahia. Salvador, SEPLANTEC, s.d. Xerocópia.

MARCUSE. Peter. Enclaves sim; guetos não: a segregação e o Estado. Espaço \& Debates: revista de Estudos Regionais e Urbanos, São Paulo, v.24, n.45, p.24-33, jan./jun., 2004

MARQUES, Eduardo; TORRES, Haroldo. (Org.) São Paulo: segregação pobreza e desigualdades sociais. São Paulo: Editora SENAC, 2005. 329p.

MATOS, Carlos A. de. Redes, nodos e cidades: transformação da metrópole latino americana. In: RIBEIRO, Luiz César Q. (Org.) Metrópoles: entre a coesão e a fragmentação, a cooperação e o conflito. São Paulo: Ed. Perseu Abramo; Rio de Janeiro: FASE/Observatório das Metrópoles, 2004.

Santiago do Chile, globalizacion y expansion metropolitana: lo que existia sigue existiendo. $\overline{E U R E}$, Santiago do Chile, v.25, n.76, 1999.

PEREIRA, Gilberto Corso. Habitação popular em Salvador: o caso das Malvinas. 1989. Dissertação (Mestrado) - Programa de Pós-Graduação em Arquitetura e Urbanismo da Faculdade de Arquitetura da Universidade Federal da Bahia, Salvador, 1989. Atlas digital Salvador. Salvador: LCAD/UFBA, 2000. CD-ROM.

; SILVA Bárbara-Christine Nentwig. Geoprocessamento e urbanismo. In: MENDES, I.; GERARDI,

L. (Org.) Teorias, técnicas, espaços e atividades. Rio Claro: UNESP/PPG, 2001.

; CARVALHO, Silvana. Vazios urbanos. Salvador, 2006. Relatório de pesquisa. 
PRETECEILLE, Edmond. A construção social da segregação urbana: convergências e divergências. Espaço \& Debates: revista de Estudos Regionais e Urbanos, São Paulo, v.24, n.45, p.11-23, jan./jun., 2004.

. A evolução da segregação social e das desigualdades urbanas: 0 caso da metrópole parisiense nas últimas décadas. Caderno CRH: revista do Centro de Recursos Humanos da UFBA, Salvador, n.36, p.2748, 2003.

PRÉTECEILLE, Edmond. La ségregation sociale a-t-elle augmenté? La metrópole parisienne entre polarisation et mixité. Societés Contemporaines, Paris, n.62. 2006

REIS, Nestor Goulart, Notas sobre urbanização dispersa e novas formas de tecido urbano. São Paulo: Via das Artes, 2006.

RIBEIRO, Luiz César Q. Transformações da estrutura sócio-espacial, segmentação e polarização na Região Metropolitana do Rio de Janeiro. Cadernos Metrópole, São Paulo, n. 1, 1999

. (Org.) O futuro das metrópoles: desigualdade e governabilidade. Rio de Janeiro: Revan, FASE/ Observatório das Metrópoles, 2000.

; LAGO, Luciana. O espaço social nas grandes metrópoles brasileiras: São Paulo, Rio de Janeiro e Belo Horizonte. Revista Brasileira de Estudos Urbanos e Regionais. Belo Horizonte, n.3, p.111-129, 2000.

(Org.). Metrópole: entre a coesão e a fragmentação, a cooperação e o conflito. São Paulo: Ed. Perseu Abramo; Rio de Janeiro: FASE/Observatório das Metrópoles, 2004.

Segregación residencial y segmentación social: el efecto vecindario em la reprodución de la pobreza em lãs metropolis brasileñas. In: LEGUIZAMON, Sônia Alvarez (Comp.) Trabajo y producción de la pobreza em Latinoamerica y el Caribe. Buenos Aires: CLACSO, 2005.

SABATINI, Francisco. La segregación residencial em las ciudades latinoamericanas: causas, posibles políticas y rol de los mercados de suelo. In: ARENAS, F.; HIDALGO, R.; COLL, J.L. Los nuevos modos de gestion de la metropolizacion. Santiago do Chile: Instituto de Geografia, 2003.

; CÁCERES, Gonzalo; CERDA, Jorge. Segregação residencial nas principais cidades chilenas: tendências das três últimas décadas e possíveis cursos de ação. Espaço \& Debates: revista de Estudos Regionais e Urbanos. São Paulo, v.24, n.45, jan./jun., p.64-74, 2004.

SASSEN, Saskia. The global city: New York, London, Tokyo. New Jersey: Princeton University Press, 1991.

SHAPIRA, Marie France Prevot. Segregação, fragmentação, sucessão: a nova geografia social de Buenos Aires. Novos Estudos CEBRAP, São Paulo, n.56, mar., p.169-183, 2000.

SILVA, Barbara Christina; SILVA, Sylvio B. de M.; CUNHA, Conceição; NASCIMENTO, Dario; SOUZA, Jaimeval; PEREIRA, Gilberto C. Atlas escolar Bahia: espaço geo-histórico e cultural, $2^{\mathrm{a}}$ ed. João pessoal: Grafset, 2004.

SOUZA, Ângela Gordilho. Limites do habitar: segregação e exclusão na configuração urbana contemporânea de Salvador e perspectivas no final do século XX. Salvador: EDUFBA, 2000.

TASCHNER, Suzana P.; BOGUS, Lúcia M. M. São Paulo como patckwork: unindo fragmentos de uma cidade segregada. Cadernos Metrópole, São Paulo, n.1, 1999.

VEIGA, Danilo. Entre a desigualdade e a exclusão social: estudo de caso da Grande Montevidéu. Caderno CRH: revista do Centro de Recursos Humanos da UFBA. Salvador, v.18, n.45, p.341-354, set./ dez., 2005.

VELTZ, Pierre. Mondialisatiom, villes et territoires. L'economie d'archipel. Paris: Press Universitaires de France, 1996.

VILLAÇA, Flávio. Espaço intra-urbano no Brasil. São Paulo: Estúdio Nobel, 1998. 373p.

WACQUANT, Loic. Os condenados da cidade: estudos sobre marginalidade avançada. Rio de Janeiro: REVAN/FASE, 2001. 



\section{TRABALHO, RENDA E POBREZA NA REGIÃO METROPOLITANA DE SALVADOR'}

Inaiá Maria Moreira de Carvalho*

\section{INTRODUÇÃO}

O presente capítulo aborda as condições de trabalho e renda que prevalecem em Salvador e em sua região metropolitana, levando em conta tanto a trajetória e especificidades locais como o impacto das transformações econômicas e sociais recentes sobre esse tipo de região.

Dando início a essa discussão, vale lembrar como ao longo da história, e na grande maioria dos países, as metrópoles têm concentrado as atividades mais dinâmicas, o poder e a riqueza, ao lado da população. Além disso, na fase contemporânea do capitalismo, a nova arquitetura produtiva, constituída a partir do processo de globalização, tem contribuído para revitalizar o seu papel e o seu crescimento, transformando-as em sítios estratégicos para a economia mundializada, com impactos significativos sobre a sua organização e funcionamento, qualidade de vida urbana e condições sociais (Sassen, 1991; Veltz, 1996; Borja; Castels, 1997; Alonso, 2000; Mattos, 2004; Ribeiro, 2004).

No caso do Brasil não tem sido diferente. Em 1970, São Paulo e Rio de Janeiro já conformavam amplas áreas metropolitanas, onde se concentravam, respectivamente, $15,63 \%$ e $13,23 \%$ da população urbana do Brasil. Belém, Belo

\footnotetext{
* Pesquisadora do Centro de Recursos Humanos da Universidade Federal da Bahia. Professora do Mestrado em Políticas Sociais e Cidadania da Universidade Católica de Salvador e do Programa de Pós-Graduação em Ciências Sociais da Universidade Federal da Bahia. Bolsista do CNPq.

${ }^{1}$ Versão modificada e atualizada para esta edição do capítulo elaborado anteriormente pela autora e por Ana Luiza Machado Codes sobre Ocupação, Pobreza e Desigualdades na Região Metropolitana de Salvador. A autora agradece a Leormínio Moreira Bispo Filho e a Luiz Chateaubriand Cavalcanti dos Santos pela apuração dos dados da PED.
} 
Horizonte, Curitiba, Fortaleza, Porto Alegre, Recife e Salvador, também capitais de estado, abrigavam, conjuntamente, outros $16,7 \%$, evidenciando que o fenômeno da metropolização se ampliava, mas sem romper o hiato que distingue esse conjunto de cidades (Moura et al., 2004). Contudo, o avanço da industrialização substitutiva de importações, as políticas de desenvolvimento regional implementadas pelo governo federal e as inversões de grandes empresas estatais promoveram uma maior articulação e complementaridade entre os diversos espaços que compõem a nação brasileira, contribuindo para uma certa descentralização das atividades produtivas e para o crescimento e modernização de algumas áreas, como as capitais nordestinas (Recife, Fortaleza e Salvador), que assumiram uma configuração mais efetivamente metropolitana.

Com a evolução desses processos, São Paulo e Rio de Janeiro (consideradas, respectivamente, como a cidade "global" e a gateway city do Brasil), e suas respectivas regiões, abrigavam 28,6 milhões de pessoas no ano 2000, representando $17 \%$ da população do país, sendo que os pólos metropolitanos concentravam um número maior de habitantes que o conjunto dos demais municípios. Aí se encontrava, também, $18 \%$ da PEA brasileira, $17 \%$ da população ocupada, $21 \%$ do pessoal vinculado à indústria de transformação e $17,2 \%$ da massa de rendimentos do Brasil. As regiões metropolitanas polarizadas por metrópoles "nacionais" (Fortaleza, Recife, Salvador, Belo Horizonte, Curitiba e Porto Alegre) e pelo Distrito Federal agregavam 23 milhões de pessoas, correspondendo a 13,6\% da população nacional, e o expressivo estoque de 11,3 milhões de ocupados, 1,8 milhão deles em atividades industriais (Moura et al., 2004).

Como se sabe, porém, a urbanização e o desenvolvimento brasileiros vêm se mostrando, historicamente, incapazes de assegurar melhores condições de trabalho e de subsistência para o conjunto da população urbana. Ainda que os referidos processos tenham sido associados a uma expansão e diversificação da estrutura produtiva e ocupacional nas cidades (com a criação de novos empregos em setores como a indústria de transformação, transportes, energia, construção civil, administração pública, finanças, serviços auxiliares à produção e de consumo coletivo), a relação contratual assalariada não chegou a se universalizar. A abundância de mãode-obra e a dimensão do exército de reserva permitiram tanto a compressão salarial como uma coexistência entre o "moderno" e o "tradicional", com a persistência de relações de trabalho precárias em setores como o pequeno comércio, os serviços pessoais ou as atividades domésticas. Mesmo nos centros mais dinâmicos, uma reduzida camada de alta renda e camadas médias ampliadas, diversificadas e por vários anos em ascenção, passaram a conviver com o proletariado industrial e com um vasto e heterogêneo contingente de trabalhadores pobres, de vida incerta e duvidosa. Nos anos 60, do século passado, isso chegou a suscitar considerações sobre o caráter "sociepático" dessa urbanização, assim como debates e polêmicas sobre a "marginalidade", para enfocar as dificuldades e "distorções" da incorporação dos trabalhadores aos processos produtivos (Machado da Silva, 2002; Nun, 2004). 
Até a década de 1970, contudo, as elevadas taxas de crescimento econômico, em uma época em que a expansão da produção implicava maior demanda de trabalho, ampliaram as oportunidades de acesso aos denominados "empregos formais" (com a proteção e benefícios aos mesmos associados) e as possibilidades de integração e de mobilidade social. Mas essa tendência a uma melhor integração através do mercado se interrompeu na década de 1980 (a chamada "década perdida"), com o esgotamento do padrão de financiamento e do padrão de desenvolvimento até então implementados. Houve um agravamento da crise econômica, da crise fiscal do Estado e uma intensa aceleração do processo inflacionário, e, na década de 1990, os caminhos do Brasil foram reorientados, com a implementação de um conjunto de políticas convergentes, recomendadas pelas agências multilaterais. Denominadas como "ajuste estrutural", "reformas estruturais" ou reformas orientadas para o mercado, elas envolveram um programa de estabilização, uma abertura econômica intensa e rápida, um amplo programa de privatizações, a ênfase nos mecanismos do mercado e uma profunda reformulação do papel do Estado, tanto em termos do seu protagonismo econômico e de suas funções reguladoras como de suas responsabilidades como provedor de políticas econômicas e sociais.

Essas medidas sempre foram apresentadas como condições para que 0 Brasil se adaptasse às exigências da economia mundializada e retomasse o seu desenvolvimento. Efetivamente, porém, elas conduziram a uma inserção passiva e subordinada do país ao processo de globalização e a um agravamento do seu quadro social, em um período marcado por baixos níveis de crescimento econômico, deterioração das condições de trabalho e renda da população e uma persistência ou agravamento das desigualdades sociais e espaciais.

Com a desaceleração da produção, baixos níveis de investimento, aumento da dívida externa e interna, dependência dos mercados financeiros e capitais voláteis e vulnerabilidade aos ataques especulativos e às crises internacionais, o Brasil cresceu muito pouco na década de noventa (avaliada como uma segunda década perdida) e nos primeiros anos deste novo milênio. Além disso, 0 ajuste e a reestruturação produtiva foram marcados por uma expressiva destruição de postos de trabalho, notadamente no setor industrial. Com a constituição de uma economia de base urbano-industrial, no Brasil, há décadas que a população e a ocupação na agropecuária vêm se reduzindo. Na medida em que o setor industrial também restringiu o emprego de mão-de-obra, os serviços passaram a absorver um maior número de trabalhadores. Mas esse setor é muito heterogêneo, englobando desde os serviços mais modernos até o pequeno comércio, a prestação de serviços pessoais e outras atividades precárias e mal remuneradas do chamado mercado informal, e sua expansão não consegue compensar a destruição de postos que vem se dando nos demais setores.

Conseqüentemente, ocorre uma ampliação do tradicional excedente da mão-de-obra, vinculada a um aumento da seletividade patronal e das dificuldades 
de acesso aos (escassos) postos de trabalho e à queda dos rendimentos daqueles que permanecem ocupados, notadamente nas regiões metropolitanas.

Como ilustração desses fatos, vale mencionar que, de acordo com o último Censo, no conjunto formado pelas regiões metropolitanas globais e nacionais, encontravam-se $40 \%$ dos desempregados do país, no ano 2000 (Moura et al., 2004). Segundo o DIEESE, naquele mesmo ano, a duração média do tempo de procura por trabalho chegava a 11 meses em Belo Horizonte, 15 meses no Distrito Federal, 10 em Porto Alegre, 12 em Salvador e 10 em São Paulo. Além disso, o percentual de desempregados em busca de trabalho há mais de um ano alcançava $21 \%$ em Belo Horizonte, 31,6\% no Distrito Federal, 21,6\% em Porto Alegre, 26,5\% em Salvador e $21,8 \%$ em São Paulo.

Entre os ocupados, em 2003, os trabalhadores que não contribuíam para a previdência, (estando excluídos, portanto, da proteção trabalhista e da seguridade social), representavam 61,0\% em Belém, 56,1\% em Fortaleza, 50,9\%, em Recife e $47,5 \%$ em Salvador, conforme a PNAD. Mesmo nas metrópoles mais desenvolvidas essa freqüência era expressiva, alcançando 39,7 em Belo Horizonte, $38,2 \%$ no Rio de Janeiro, 37,5\% em São Paulo, 37,3\% em Curitiba, 37,4\% em Porto Alegre e $34,9 \%$ no Distrito Federal. Ademais, tomando-se como indicador de pobreza uma renda mensal familiar per capita inferior a meio salário mínimo e, de indigência, uma renda abaixo de um quarto do salário mínimo, os pobres e indigentes constituíam $30,4 \%$ da população de Belém, $36,6 \%$ de Fortaleza, 31,8\% de Recife e $30,9 \%$ de Salvador. Refletindo as desigualdades inter-regionais do país, esses números decresciam para 18,7\% em Belo Horizonte, 15,6\% no Distrito Federal, 13,7\% em Curitiba, 11,6\% no Rio de Janeiro, 11,5\% em São Paulo e 11,2\% em Porto Alegre $^{2}$ (IBGE, 2004). Note-se que o número absoluto de moradores pobres mostrase especialmente elevado nas regiões metropolitanas de São Paulo e do Rio de Janeiro, em decorrência do tamanho da sua população.

É verdade que a partir desse referido ano o Brasil vem obtendo taxas de crescimento econômico um pouco mais significativas e o mercado de trabalho experimentando uma certa recuperação, com um crescimento dos empregos regulares assalariados, uma redução relativa do desemprego, das ocupações por conta própria e das atividades sem remuneração (Pochmann, 2006). Além disso, a elevação do valor real do salário mínimo e algumas políticas de transferência de renda (como o Benefício de Prestação Continuada e o Bolsa Família) também tem contribuído para atenuar os efeitos adversos da crise social. Contudo, ela continua

\footnotetext{
${ }^{2}$ Com base nos dados da PNAD e em procedimentos mais elaborados - que levaram em conta a renda e o custo de vida de acordo com as especificidades de cada região -, trabalho recente de Sônia Rocha calculou que, em 2004, a pobreza metropolitana atingia 21 milhões, representando 38,7\% dos habitantes, percentual mais elevado que os $29,5 \%$ residentes nas demais áreas urbanas, que os $35,4 \%$ que estavam nas áreas rurais e que os $32,2 \%$ encontrados no conjunto do Brasil. Já os indigentes representavam $13,3 \%$ dos moradores nas áreas rurais, 7,9\% nas áreas metropolitanas e 6,6\% nas demais áreas urbanas (Folha de São Paulo, 29 jan., 2006, p.B1, B3).
} 
acentuada e concentrada nas regiões metropolitanas, atingindo especialmente os jovens, cujas oportunidades de uma melhor incorporação produtiva persistem restritas. Analisando a inserção ocupacional deste segmento, com base nos dados da PNAD de 2006, Fernandes (2008) constatou que na faixa dos 15 a 19 anos a taxa de desemprego chegava a $34,5 \%$ nas regiões metropolitanas e que, entre os ocupados, $44 \%$ trabalhavam como empregados sem carteira assinada, 8,1\% por conta própria e $5,1 \%$ como não remunerados. ${ }^{3}$ Ademais, $8,9 \%$ dos jovens não estudavam nem trabalhavam e, entre os $50 \%$ mais pobres, esse percentual atingia $11,2 \%$.

\section{SALVADOR E SUA REGIÃO METROPOLITANA}

Em Salvador e na sua Região Metropolitana os problemas assinalados têm um caráter histórico e especialmente acentuado, decorrendo, especialmente, até a primeira metade do século passado, da estagnação e do atraso econômico da velha capital e dos municípios do seu entorno.

Como se sabe, fundada no início do período colonial, com funções políticoadministrativas e mercantis, Salvador sediou o governo geral do Brasil até 1763 como a mais importante cidade brasileira. Mas, com a transferência da capital do país para o Rio de Janeiro, o declínio da base agro-exportadora local e, posteriormente, a constituição de um mercado unificado nacionalmente e a concentração industrial no Centro-Sul, a cidade foi afetada negativamente, experimentando um longo período de declínio que se refletiu sobre as condições de trabalho e subsistência da sua população,

Na década de 1950, porém, a descoberta e exploração de petróleo no Recôncavo baiano (por algumas décadas responsável pela maior parte da produção nacional) estimulou o crescimento econômico, populacional e urbano de Salvador e de alguns municípios que hoje integram a sua região metropolitana, como Candeias e Madre de Deus. Na década de sessenta a região recebeu alguns investimentos industriais incentivados pela SUDENE e, dos anos 1970 para 1980, os esforços desenvolvimentistas do governo federal para complementar a matriz industrial brasileira, com a produção de insumos básicos e bens intermediários, levaram à implantação do Pólo Petroquímico de Camaçari e do Complexo do Cobre.

Esses e outros investimentos tiveram um impacto extraordinário sobre a velha capital baiana, convertendo a indústria no foco dinâmico da economia regional e ampliando as articulações entre Salvador e os municípios vizinhos, que sediam os novos empreendimentos, conformando a Região Metropolitana de Salvador (RMS).

Ainda que a presença da Petrobrás, a criação do Centro Industrial de Aratu ou a instalação do Pólo Petroquímico de Camaçari tivessem vínculos relativamente reduzidos com os demais setores da economia regional e estadual,

${ }^{3}$ Já nas áreas não metropolitanas, a taxa de desemprego na faixa dos 15-19 anos era de 18,2\%. 
os investimentos industriais estimularam, direta e indiretamente (via gasto público estadual e transferências federais), o surgimento de novas atividades e a expansão e modernização de outras. A administração pública ganhou maior peso, o varejo acelerou sua renovação, com a multiplicação de supermercados e shopping centers, e os serviços de consumo intermediário ou final (engenharia, transporte, telecomunicações) conheceram significativo desenvolvimento.

Com isso, as atividades agropecuárias perderam importância na RMS, enquanto o emprego urbano avançou em participação, com o surgimento de novas empresas e a criação de várias instituições públicas, estatais ou sociais, concentradas em Salvador. As classes médias, cujo peso era historicamente reduzido, se ampliaram e diversificaram, com o crescimento de empregados de escritório e uma maior demanda de técnicos e de profissionais de qualificação superior, como administradores, economistas, engenheiros, contadores, advogados, professores e profissionais de saúde. 0 emprego na indústria de transformação se expandiu, principalmente a partir da implementação do Complexo Petroquímico de Camaçari que, em pouco mais de sete anos, criou cerca de 20.000 empregos diretos (levando à emergência de um operariado industrial moderno, com qualificação, salários e benefícios bem mais elevados que a média local), além de outros 25.000 indiretos, nas empresas prestadoras de serviço. A construção civil foi dinamizada pela implantação das indústrias e por uma intensa renovação da cidade, criando vários novos postos de trabalho, e tanto as demandas das empresas como as expansões da massa salarial e do consumo ampliaram as oportunidades para a prestação de serviços, de um modo mais geral. Com todos esses movimentos, até a década de 80 do século passado, Salvador e outros municípios da RMS tiveram uma criação dinâmica de empregos, ampliando, diversificando e modernizando 0 seu mercado de trabalho (Carvalho; Souza, 1980; Borges; Filgueiras, 1995; Carvalho; Almeida; Azevedo, 2001; Borges, 2003).

Mas o perfil da nova indústria, orientada para a produção de bens intermediários e centrada em grandes plantas automatizadas de produção contínua, a exiguidade do mercado consumidor regional - pouco atrativo para investimentos com maior capacidade de absorção de mão-de-obra, como a indústria de bens de consumo final - e a centralização espacial e empresarial mantiveram a parcela de trabalhadores ocupados por esse setor bem mais reduzida que em outras metrópoles brasileiras. Além disso, as transformações assinaladas incidiram sobre um mercado de trabalho marcado pela super oferta de mão-de-obra de baixa qualificação, reforçada pela atração de fluxos migratórios para Salvador e sua área metropolitana, pela vinculação de uma grande parcela da força de trabalho a ocupações precárias e de baixa remuneração e por uma reduzida oferta de postos de trabalho de qualidade.

Por isso, mesmo na fase de maior crescimento econômico - ou seja, entre 1970 e 1985 -, quando a capital baiana colocou-se entre as metrópoles mais dinâmicas do país, os problemas ocupacionais e a pobreza de amplos segmentos da sua população mostraram-se persistentes, agravando-se com a crise e as 
transformações dos anos $1990 .{ }^{4} \mathrm{Na}$ medida em que a referida indústria dependia essencialmente dos capitais e mercados do centro-sul e do exterior, o esgotamento do padrão desenvolvimentista, a abertura, a reestruturação da economia brasileira e a nova orientação neoliberal do Estado (com o abandono das políticas industrial e de desenvolvimento regional) tiveram um impacto especialmente adverso sobre a estrutura produtiva local, afetando a dinâmica econômica e especialmente, o nível e as condições de emprego.

Como em outras áreas do país, as mudanças assinaladas implicaram uma rápida introdução de novas tecnologias e novos formatos organizacionais, que alteraram tanto 0 consumo como a localização da mão-de-obra. Empresas e outras organizações modificaram bastante suas estruturas e processos, passando a operar on line ou com base no just in time, a enxugar seus quadros, organizar-se em redes de clientes e fornecedores, eliminar departamentos de retaguarda (contabilidade ou armazenagem, por exemplo) e terceirizar várias atividades, destruindo ou precarizando um grande volume de postos de trabalho. Na RMS é emblemático o caso do complexo petroquímico, onde a mão-de-obra empregada foi reduzida para cerca de um terço do máximo alcançado nos anos 1980, com uma larga utilização do trabalho terceirizado e temporário. A terceirização avançou não apenas na petroquímica como na indústria metal-mecânica e em alguns importantes ramos da economia soteropolitana, como os serviços financeiros e de utilidade pública (Carvalho; Almeida; Azevedo, 2001).

Em uma metrópole marcada historicamente por problemas de incorporação da mão-de-obra isto produziu uma verdadeira desestruturação do mercado de trabalho (Borges, 2003). A precariedade ocupacional se ampliou, os níveis de remuneração decresceram e, explicitando os estreitos limites de incorporação produtiva da economia de Salvador e de sua região metropolitana (sob qualquer condição), muitas vezes encobertos pelo trabalho precário e mal remunerado, o desemprego se elevou bastante, conferindo à capital baiana um triste campeonato no que se refere a essa questão. ${ }^{5}$

\footnotetext{
${ }^{4}$ Segundo estimativas do IPEA, o crescimento do PIB na capital baiana teria alcançado em média $9,1 \%$ ao ano entre 1970-1975, 11,3\% entre 1975-1980, 3,3 entre 1980-1985 e 5,7\% entre 1985-1990, mas caído para $1 \%$ entre 1990-1996.

${ }^{5}$ Informações coletadas pelo IBGE sobre a taxa média de desemprego aberto nas principais regiões metropolitanas do país evidenciam um agravamento geral desse problema a partir da década de 1990. Mas em nenhuma dessa áreas esse fenômeno foi tão acentuado quanto na RMS, onde essa taxa variou de $6,2 \%$ em 1991 até $15,7 \%$ em 2005. Com procedimentos mais elaborados, que levam em conta não apenas 0 desemprego aberto como o desemprego total (ou seja, a soma do desemprego aberto mais o desemprego por "bico" e por desalento), a Pesquisa de Emprego e Desemprego, efetuada pela UFBA/SEI/SEPLANTEC/ SEADE/DIEESE, registra números ainda mais preocupantes. Entre 1987-1988, o desemprego total era de $15,7 \%$ em Salvador e 15,8\% na Região Metropolitana. Entre 1997-1998, as taxas se elevaram para $21,8 \%$ e $23,2 \%$, e entre $2003-2004$ chegaram, respectivamente, a $26,0 \%$ e $26,8 \%$. Entre os que permaneceram ocupados, o percentual de trabalhadores na denominada "informalidade" passou de $37,7 \%$, em 1987-1988, para 44,9\% em 2003-2004, em Salvador e de 41,9\% para 45,2\% na Região Metropolitana (Almeida; Damasceno, 2005).
} 
Assim, as mudanças associadas ao ajuste e à reestruturação produtiva para a abertura da economia brasileira à dinâmica da globalização tiveram um claro impacto sobre a estrutura social da RMS. Seu proletariado industrial, por exemplo, reduziu-se drasticamente com as privatizações e, sobretudo, a terceirização, interrompendo o processo de formação de uma classe operária moderna, reivindicativa e politizada, que vinha se conformando a partir do pólo petroquímico de Camaçari. Com a transformação das relações e condições de trabalho cresceu o segmento dos pequenos empregadores e o proletariado terciário. Os setores médios parecem ter mantido a sua participação na estrutura social, mas com mudanças na sua composição (a exemplo da redução relativa dos assalariados, do crescimento dos ocupados por conta própria e do peso dos que trabalham em saúde e educação) e, principalmente, um expressivo empobrecimento.

Com a transferência de determinadas empresas e atividades de Salvador para São Paulo (metrópole global do Brasil), o grupo de grandes empresários e dirigentes também parece ter sido afetado. Contudo, os fenômenos em apreço levaram sobretudo, ao crescimento do sub-proletariado, ampliando o contingente de trabalhadores de sobrevivência e de desempregados e acentuando um dos traços mais característicos da RMS, que persiste como um mar de pobreza com algumas ilhas de afluência.

Analisando-se a estrutura social da RMS com a metodologia que vem sendo utilizada pelo Observatório das Metrópoles e os dados do último Censo, encontra-se um pequeno grupo de maior nível de renda, composto pelos grandes empregadores locais, por dirigentes do setor público e do setor privado e por profissionais autônomos ou empregados de nível superior, concentrados, fundamentalmente, na Orla Atlântica e em algumas poucas áreas "nobres" de Salvador e de Lauro de Freitas; os setores de médios e pequenos empregadores, com um peso mais reduzido que em outras metrópoles brasileiras, um contingente expressivo de trabalhadores em atividades terciárias e um proletariado secundário, cuja participação na indústria de transformação (moderna ou tradicional) é especialmente restrita. Os trabalhadores na agropecuária têm um peso relativamente pequeno e, como seria de esperar, estão concentrados nos municípios menos desenvolvidos e integrados ao aglomerado metropolitano. Mas a marca básica da RMS é a dimensão e o peso do subproletariado e da reserva de mão-deobra (que se expressa pelo percentual de prestadores de serviços não especializados, trabalhadores domésticos, ambulantes e biscateiros), ao lado de elevado nível de desemprego.

Conforme assinalado, a constituição da RMS foi articulada à implantação de novas e modernas atividades econômicas em municípios de base agrícola, localizados no entorno de Salvador, envolvendo a extração de petróleo no município e imediações de Candeias, a instalação de uma refinaria em São Francisco do Conde e de um terminal marítimo em Madre de Deus, a implantação do Pólo Petroquímico e de outras indústrias em Camaçari, a presença do Centro Industrial 
Tabela 1 - Estrutura social - Região Metropolitana de Salvador

\begin{tabular}{|c|c|c|}
\hline Categorias Socioocupacionais & n. absoluto & $\%$ \\
\hline \multicolumn{3}{|l|}{ Grandes empregadores e dirigentes } \\
\hline Grandes empregadores & 7.287 & 0,7 \\
\hline Dirigentes do setor público & 2.751 & 0,2 \\
\hline Dirigentes do setor privado & 3.346 & 0,3 \\
\hline \multicolumn{3}{|l|}{ Trabalhadores Intelect uais } \\
\hline Profissionais autônomos de nível superior & 13.250 & 1,2 \\
\hline Profissionais empregados de nível superior & 34.147 & 3,1 \\
\hline Profissionais estatutários de nível superior & 7.217 & 0,6 \\
\hline Professores de nível superior & 18.427 & 1,7 \\
\hline \multicolumn{3}{|l|}{ Pequenos empregadores } \\
\hline Pequenos empregadores & 27.133 & 2,4 \\
\hline \multicolumn{3}{|l|}{ Trabalhadores em Ocupações Médias } \\
\hline Ocupações de escritório & 114.441 & 10,3 \\
\hline Ocupações de supervisão & 46.385 & 4,2 \\
\hline Ocupações técnicas & 59.792 & 5,4 \\
\hline Ocupações médias de saúde e educação & 54.474 & 4,9 \\
\hline Ocupações de segurança pública, justiça e correios & 24.104 & 2,2 \\
\hline Ocupações artísticas e similares & 12.165 & 1,1 \\
\hline \multicolumn{3}{|l|}{ Trabalhadores do Setor Secundário } \\
\hline Trabalhadores da indústria moderna & 45.496 & 4,1 \\
\hline Trabalhadores da indústria tradicional & 35.341 & 3,2 \\
\hline Trabalhadores da construção civil & 89.061 & 8,0 \\
\hline Trabalhadores dos serviços auxiliares & 46.415 & 4,2 \\
\hline \multicolumn{3}{|l|}{ Trabalhadores do Terciário Especializado } \\
\hline Trabalhadores do comércio & 111.232 & 10,0 \\
\hline Prestadores de serviços especializados & 127.938 & 11,5 \\
\hline \multicolumn{3}{|l|}{ Trabalhadores do Terciário Não Especializado } \\
\hline Prestadores de serviços não especializados & 59.375 & 5,3 \\
\hline Trabalhadores domésticos & 109.535 & 9,8 \\
\hline Trabalhadores ambulantes & 47.092 & 4,2 \\
\hline Biscateiros & 6.771 & 0,6 \\
\hline \multicolumn{3}{|l|}{ Trabalhadores Agrícolas } \\
\hline Agricultores & 12.783 & 1,1 \\
\hline
\end{tabular}

Fonte: IBGE. Censo Demográfico, 2000. Dados da Amostra.

de Aratu e a crescente urbanização de Simões Filho e de Lauro de Freitas, entre outras condições. As características desse processo e o caráter seletivo e limitado dos seus benefícios, porém, contribuíram para a persistência de uma diferenciação significativa no âmbito da região.

Analisando-se o seu impacto sobre a estrutura social confirma-se, por exemplo, que o contingente de maior renda (composto por grandes empregadores, 
Tabela 2 - Estrutura social - municípios da Região Metropolitana de Salvador - 2000

\section{\begin{tabular}{l|l|l|l} 
Categorias Socioocupacionais & \multicolumn{2}{|c}{ Municípios }
\end{tabular}}

\begin{tabular}{|c|c|c|c|c|c|c|c|c|c|c|}
\hline Calegontas socioocupaciontials & Salvador & L. de Freitas & Camaçari & S. Filho & Candeias & São F. do Conde & M. Deus & D. D'Ávila & Itaparica & Vera Cruz \\
\hline \multicolumn{11}{|l|}{ Grandes empregadores e dirigentes } \\
\hline Grandes empregadores & 0,71 & 1,18 & 0,18 & 0,13 & 0,17 & 0,30 & - & 0,22 & 0,21 & \\
\hline Dirigentes do setor público & 0,25 & 0,28 & 0,15 & 0,21 & 0,20 & 0,52 & 0,51 & 0,44 & 0,37 & - \\
\hline Dirigentes do setor privado & 0,29 & 0,45 & 0,18 & 0,31 & 0,62 & 0,16 & 0,32 & 0,75 & 0,47 & 0,08 \\
\hline \multicolumn{11}{|l|}{ Trabalhadores Intelectuais } \\
\hline Profissionais autônomos de nível superior & 1,32 & 1,16 & 0,43 & 0,35 & 0,13 & 0,10 & 0,61 & 0,07 & 1,21 & 1,01 \\
\hline Profissionais empregados de nível superior & 3,43 & 2,90 & 0,98 & 0,62 & 0,72 & 0,19 & 0,25 & 0,96 & 0,66 & 0,89 \\
\hline Profissionais estatutários de nível superior & 0,75 & 0,39 & 0,08 & 0,08 & 0,13 & - & 0,22 & - & - & 0,11 \\
\hline Professores de nível superior & 1,83 & 0,73 & 0,70 & 0,86 & 0,46 & 0,76 & 0,63 & 0,89 & 1,24 & 1,36 \\
\hline \multicolumn{11}{|l|}{ Pequenos empregadores } \\
\hline Pequenos empregadores & 2,53 & 3,68 & 1,76 & 1,51 & 1,17 & 0,08 & 1,38 & 1,48 & 1,08 & 1,58 \\
\hline \multicolumn{11}{|l|}{ Trabalhadores em Ocupaçōes Médias } \\
\hline Ocupaçōes de escritório & 10,86 & 7,79 & 7,26 & 7,91 & 6,31 & 10,45 & 6,47 & 7,66 & 4,54 & 4,78 \\
\hline Ocupações de supervisão & 4,41 & 4,09 & 2,62 & 3,24 & 1,74 & 3,00 & 3,06 & 3,07 & 2,30 & 1,70 \\
\hline Ocupaçōes técnicas & 5,82 & 3,89 & 3,25 & 2,80 & 2,47 & 4,16 & 2,76 & 3,28 & 1,58 & 1,17 \\
\hline Ocupações médias de saúde e educação & 4,92 & 3,62 & 3,80 & 5,19 & 6,41 & 7,39 & 6,65 & 4,00 & 7,01 & 5,68 \\
\hline Ocupaçōes de segurança pública, justiça e correios & 2,39 & 1,16 & 0,74 & 1,29 & 0,54 & 1,75 & 0,21 & 1,34 & 0,82 & 2,54 \\
\hline Ocupações artísticas e similares & 1,17 & 0,99 & 0,83 & 0,64 & 0,42 & 0,50 & 1,19 & 0,24 & 0,21 & 0,83 \\
\hline \multicolumn{11}{|l|}{ Trabalhadores do Setor Secundário } \\
\hline Trabalhadores da indústria moderna & 3,49 & 3,55 & 6,96 & 7,08 & 13,08 & 5,47 & 12,14 & 11,25 & 2,28 & 1,58 \\
\hline Trabalhadores da indústria tradicional & 3,12 & 3,53 & 3,28 & 4,50 & 3,31 & 1,70 & 2,66 & 4,22 & 2,00 & 1,77 \\
\hline Trabalhadores da construção civil & 7,10 & 10,90 & 14,58 & 11,14 & 12,39 & 10,72 & 11,81 & 11,14 & 9,42 & 14,08 \\
\hline Trabalhadores dos serviços auxiliares & 3,81 & 4,14 & 6,22 & 8,52 & 6,83 & 2,72 & 6,36 & 6,50 & 4,56 & 3,32 \\
\hline \multicolumn{11}{|l|}{ Trabalhadores do Terciário Especializado } \\
\hline Trabalhadores do comércio & 10,04 & 10,76 & 9,25 & 11,21 & 9,99 & 4,57 & 8,72 & 8,30 & 7,60 & 7,59 \\
\hline Prestadores de serviços especializados & 11,58 & 11,03 & 10,80 & 10,24 & 11,90 & 6,17 & 13,82 & 9,83 & 16,61 & 11,20 \\
\hline \multicolumn{11}{|l|}{ Trabalhadores do Terciário Não Especializado } \\
\hline Prestadores de serviços não especializados & 5,13 & 5,94 & 5,61 & 6,07 & 5,25 & 13,18 & 7,33 & 6,51 & 8,11 & 6,81 \\
\hline Trabalhadores domésticos & 9,72 & 14,11 & 11,92 & 6,87 & 5,18 & 7,26 & 3,89 & 8,47 & 10,80 & 14,11 \\
\hline Trabalhadores ambulantes & 4,36 & 2,04 & 3,31 & 4,15 & 5,12 & 3,01 & 3,16 & 4,63 & 7,06 & 2,44 \\
\hline Biscateiros & 0,53 & 0,74 & 1,10 & 0,93 & 0,94 & 3,24 & 0,78 & 1,16 & 0,23 & 0,40 \\
\hline \multicolumn{11}{|l|}{ Trabalhadores Agricolas } \\
\hline Agricultores & 0,48 & 0,96 & 4,02 & 4,15 & 4,54 & 12,58 & 5,06 & 3,57 & 9,63 & 14,96 \\
\hline
\end{tabular}


dirigentes e profissionais de nível superior) e os integrantes dos estratos médios concentra-se, basicamente, em Lauro de Freitas e em Salvador. Pela dimensão da população e pelo peso das atividades industriais, em localidades cuja estrutura produtiva é pouco diversificada, os trabalhadores da indústria moderna têm uma participação um pouco mais expressiva na estrutura ocupacional de Camaçari, Simões Filho, Candeias, Dias D'Ávila e Madre de Deus, sem que a RMS apresente uma concentração operária. Também é digna de nota a participação dos trabalhadores da construção civil, de prestadores de serviços não especializados e trabalhadores agrícolas (que constituem, normalmente, os segmentos mais vulneráveis e pauperizados da pirâmide ocupacional) na maioria dos municípios, com destaque para Dias D’Ávila, Camaçari e, especialmente, Itaparica e Vera Cruz.

Em decorrência desse quadro, conforme dados do último Censo, 26,6\% da população ocupada na capital baiana, no ano de 2000, percebia um rendimento médio anual de até um salário mínimo e, $54,8 \%$, de até dois salários mínimos, em todos os trabalhos; $67 \%$ ganhava até três salários e apenas 33\% acima desse valor. Para o conjunto da Região Metropolitana, esses números eram, respectivamente, de $28 \%, 56,7 \%, 68,9 \%$ e $31,1 \%$.

Essas remunerações refletem os níveis de pobreza e de indigência encontrados em Salvador e na RMS. Considerando-se a freqüência de moradores com uma renda mensal familiar, per capita, de até meio ou de até um quarto do salário mínimo (indicadores usuais desses fenômenos), constata-se que o percentual de moradores pobres chegava, em 1991, a 35,28\%, em Salvador, e a $53,2 \%$, para a média da Região Metropolitana. Em 2000, houve um decréscimo nesses números, que passaram para $30,7 \%$ e $46,0 \%$, respectivamente. A proporção de indigentes, que alcançava 14,98\% em Salvador e 27,5\% na RMS, em 1991, também se restringiu, no ano 2000, passando para $13,45 \%$ em Salvador e para $23,1 \%$ no conjunto da região.

Tabela 3 - Pobreza e indigência na Regiāo Metropolitana de Salvador - 1991 e 2000

\begin{tabular}{l|c|c|c|c|c|c|c|c}
\hline \multirow{2}{*}{\begin{tabular}{l} 
Municípios \\
\cline { 2 - 10 }
\end{tabular}} & \multicolumn{2}{|c|}{ \% de Pobres } & \multicolumn{2}{c|}{$\begin{array}{c}\text { Intensidade da } \\
\text { Pobreza }\end{array}$} & \multicolumn{2}{c}{ \% de Indigentes } & \multicolumn{2}{c}{$\begin{array}{c}\text { Intensidade da } \\
\text { Indigência }\end{array}$} \\
\cline { 2 - 11 } & $\mathbf{1 9 9 1}$ & $\mathbf{2 0 0 0}$ & $\mathbf{1 9 9 1}$ & $\mathbf{2 0 0 0}$ & $\mathbf{1 9 9 1}$ & $\mathbf{2 0 0 0}$ & $\mathbf{1 9 9 1}$ & $\mathbf{2 0 0 0}$ \\
\hline Camaçari & 44,52 & 46,17 & 44,39 & 47,57 & 18,56 & 21,25 & 41,7 & 52,42 \\
\hline Candeias & 50,84 & 43,78 & 50,6 & 52,73 & 27,44 & 23,69 & 43,51 & 53,92 \\
\hline Dias D'Ávila & 46,89 & 44,22 & 52,88 & 53,69 & 25,61 & 24,18 & 46,24 & 58,14 \\
\hline Itaparica & 69,74 & 54,72 & 46,65 & 49,26 & 43,17 & 26,94 & 46,55 & 52,71 \\
\hline Lauro de Freitas & 46,9 & 36,24 & 44,95 & 46,89 & 20,1 & 17,01 & 42,46 & 53,36 \\
\hline Madre de Deus & 50,24 & 42,97 & 44,92 & 43,93 & 21,8 & 15,1 & 44,8 & 70,05 \\
\hline Salvador & 35,28 & 30,7 & 45 & 46,31 & 14,98 & 13,45 & 42,14 & 54,28 \\
\hline Sáo Francisco do & 69,72 & 55,48 & 54,91 & 55,64 & 41,18 & 32,81 & 45,18 & 54,92 \\
\hline Conde & 52,81 & 47,5 & 47,88 & 51,56 & 25,31 & 24,07 & 42,14 & 54,55 \\
\hline Simóes Filho & 65,55 & 58,64 & 52,89 & 53,86 & 37,17 & 32,96 & 38,91 & 52,31 \\
\hline Vera Cruz & $\mathbf{5 3 , 2}$ & $\mathbf{4 6 , 0}$ & $\mathbf{4 9 , 5}$ & $\mathbf{5 0 , 1}$ & $\mathbf{2 7 , 5}$ & $\mathbf{2 3 , 1}$ & $\mathbf{4 3 , 4}$ & $\mathbf{5 5 , 7}$ \\
\hline Média da RMS & & & & & & &
\end{tabular}

Fonte: Atlas do Desenvolvimento Humano no Brasil. Conforme METRODATA, 2004. 
O decréscimo assinalado constitui, evidentemente, um fenômeno positivo. Contudo, os números em apreço permaneceram bastante elevados e se diferenciam entre os municípios. Em Salvador, a parcela de pobres ficava próxima a um terço da população, no ano 2000, mas, nos demais municípios, aumentava bastante, atingindo $54,72 \%$ em Itaparica, 55,48\% em São Francisco do Conde e 58,64\% em Vera Cruz. Naquele mesmo ano, o percentual de indigentes era de 13,45\% em Salvador, 15,1\% em Madre de Deus, 17,01\% em Lauro de Freitas e 21,25\% em Camaçari, pólo industrial da região e único município que apresentou aumento. Cerca de um quarto dos moradores de Candeias, Simões Filho, Dias D'Ávila e Itaparica encontrava-se nessa condição e, em São Francisco do Conde e Vera Cruz, os números chegavam a 32,81\% e 32,96\%.

Por outro lado, os números relativos à intensidade desses problemas, apresentados na Tabela 3, mostram que essas pessoas dispunham de menos recursos, em 2000, que em 1991. A pobreza e a indigência se intensificaram, ${ }^{6}$ portanto, tornandose mais contundentes e aumentando a precariedade da subsistência e as dificuldades de melhoria para os que se encontravam nessa situação.

A concentração de renda é outra característica básica da área em discussão, observando-se, inclusive, uma acentuação desse fenômeno entre 1991 e 2000 . Se, no início desse período, os $20 \%$ mais pobres da população detinham $2,7 \%$ da renda, ao final eles se apropriavam de apenas 1,7\%, enquanto o quinhão dos $10 \%$ mais ricos passou de $45,7 \%$ para $48,3 \%$ da renda total.

Salvador, Lauro de Freitas e São Francisco do Conde apresentavam os níveis mais extremados de concentração da riqueza, com as camadas mais pobres da população detendo as menores fatias de renda no âmbito da RMS, enquanto os ricos se apossavam de parcelas mais elevadas. Em 2000, enquanto os $20 \%$ moradores mais pobres de Salvador, Lauro de Freitas e São Francisco do Conde se apropriavam, respectivamente, de 1,58\%,1,32\% e 1,08\% da renda, cabia aos 10\% mais ricos 53,59\%, 57,56 e 48,22\%, nessa mesma ordem, como mostra a Tabela 4.

Para uma melhor compreensão do panorama atual da RMS em termos ocupacionais e sociais, porém, cabem ainda outras considerações. Uma primeira delas é que com o fim das políticas nacionais de desenvolvimento industrial e regional e a nova ênfase na integração dos "espaços competitivos" do país à dinâmica global, em busca de novas alternativas econômicas para a Bahia e para a Região Metropolitana, tanto o governo estadual quanto os municípios têm apostado na concessão de incentivos fiscais para atração de novas indústrias e no incremento do turismo, com algum sucesso. Fugindo das "deseconomias de aglomeração" presentes no centro-sul (como os fortes sindicatos dos seus pólos industriais) e atraídas pelos incentivos e pelos baixos salários que prevalecem no Nordeste,

${ }^{6} \mathrm{O}$ indicador de intensidade de pobreza pode ser definido em termos da renda média dos pobres. Quanto maior a distância entre essa renda média e o valor da linha de pobreza, maior a intensidade da pobreza. Aliado a uma estimativa da proporção de pobres em uma sociedade, esse indicador pode informar a magnitude dos recursos que deveriam ser transferidos aos pobres para que esses tivessem, ao menos, uma renda igual à linha de pobreza. A intensidade de indigência é um indicador análogo, de interpretação semelhante, mas que desenvolve uma análise referenciada na linha de indigência. 
Tabela 4 - Renda Familiar Apropriada, por faixas da população - RMS, 2000 - \%

\begin{tabular}{l|c|c|c|c|c|c}
\hline \multicolumn{1}{|c|}{ Municípios } & $\begin{array}{c}\text { \% da renda } \\
\text { apropriada } \\
\text { pelos 20\% } \\
\text { mais } \\
\text { pobres }\end{array}$ & $\begin{array}{c}\text { \% da } \\
\text { renda } \\
\text { apropriada } \\
\text { pelos 40\% } \\
\text { mais } \\
\text { pobres }\end{array}$ & $\begin{array}{c}\text { \% da renda } \\
\text { apropriada } \\
\text { pelos 60\% } \\
\text { mais } \\
\text { pobres }\end{array}$ & $\begin{array}{c}\text { \% da renda } \\
\text { apropriada } \\
\text { pelos 80\% } \\
\text { mais pobres }\end{array}$ & $\begin{array}{c}\text { \% da renda } \\
\text { apropriada } \\
\text { pelos 20\% } \\
\text { mais ricos }\end{array}$ & $\begin{array}{c}\text { \% da renda } \\
\text { apropriada } \\
\text { pelos 10\% } \\
\text { mais ricos }\end{array}$ \\
\hline Camaçari & 2,04 & 8,39 & 19,00 & 36,85 & 63,15 & 48,16 \\
\hline Candeias & 1,87 & 8,64 & 20,91 & 41,50 & 58,50 & 42,23 \\
\hline Dias D'Ávila & 1,62 & 8,56 & 20,60 & 40,21 & 59,79 & 42,96 \\
\hline Itaparica & 1,86 & 8,22 & 18,85 & 37,58 & 62,42 & 45,04 \\
\hline Lauro de Freitas & 1,32 & 5,43 & 12,68 & 26,37 & 73,63 & 57,56 \\
\hline Madre de Deus & 2,37 & 9,61 & 21,14 & 39,78 & 60,22 & 46,05 \\
\hline Salvador & 1,58 & 6,12 & 14,17 & 29,98 & 70,02 & 53,59 \\
\hline São Francisco do Conde & 1,08 & 6,37 & 16,43 & 34,99 & 65,01 & 48,22 \\
\hline Simões Filho & 1,78 & 8,14 & 19,17 & 37,68 & 62,32 & 47,19 \\
\hline Vera Cruz & 1,22 & 6,56 & 15,70 & 32,35 & 67,65 & 52,42 \\
\hline Média da RMS & $\mathbf{1 , 7 0}$ & $\mathbf{7 , 6 0}$ & $\mathbf{1 7 , 9 0}$ & $\mathbf{3 5 , 7 0}$ & $\mathbf{6 4 , 3 0}$ & $\mathbf{4 8 , 3 0}$ \\
\hline
\end{tabular}

Fonte: METRODATA

algumas empresas tem se deslocado para o interior da Bahia e para a Região Metropolitana de Salvador.

Destaca-se, entre elas, o complexo automobilístico da Ford Nordeste, implantado em 2001, compreendendo, além da montadora, um conjunto de trinta e três empresas sistemistas e um terminal portuário exclusivo, construído na Baía de Aratu para o escoamento da produção no país e para consumidores das Américas do Sul e do Norte, além da importação de veículos. Com uma capacidade de produção de 250 mil veículos por ano, prevista para ser alcançada em 2005, foi estimado que esse Complexo geraria 7,5 mil empregos diretos e estimularia a criação de mais 35 mil empregos indiretos. Operando já em plena capacidade, o Complexo Industrial vem contribuindo para o incremento da riqueza e para a ampliação do peso da indústria no PIB da RMS (onde a mesma está concentrada) e do estado da Bahia, inclusive através da demanda de serviços. $O$ número de trabalhadores absorvidos diretamente pela empresa superou ligeiramente as estimativas, chegando a 8,5 mil em 2006, mas os salários são bem inferiores aos que prevalecem em outros pólos automobilísticos do Brasil $^{7}$ e, como seria de esperar, os impactos desses empreendimentos pouco contribuíram para alterar a estrutura ocupacional e 0 panorama social da RMS, persistindo as características que a colocaram como a terceira maior aglomeração de pobreza metropolitana do país.

A segunda diz respeito aos movimentos de expansão econômica e de recuperação do mercado de trabalho que vem se registrando no Brasil nos primeiros anos deste milênio e, principalmente, a partir de 2005, bem como aos seus impactos

${ }^{7}$ Conforme informações obtidas, junto ao Sindicato, $55,6 \%$ dos trabalhadores do complexo automobilístico percebem até dois salários mínimos. 
sobre as regiões metropolitanas. Tanto na Região Metropolitana de Salvador como em outras regiões as informações disponíveis deixam evidente uma interrupção do processo de desestruturação e precarização do mercado de trabalho que marcou a década de 1990, com um crescimento da ocupação, uma recuperação do emprego formal e uma redução do desemprego.

Dados da Pesquisa de Emprego e Desemprego, por exemplo, mostram que a despeito de uma maior pressão sobre o mercado de trabalho, com 0 incremento das taxas de participação e do total da população economicamente ativa, a economia da RMS ampliou o contingente de ocupados desde 1999, com uma contribuição fundamental do setor privado e dos serviços. Os assalariados com carteira assinada, que não constituíam mais que $29,2 \%$ dos ocupados em 1997, representam 40\% em 2007. Já os empregadores, autônomos e empregados domésticos experimentaram uma redução relativa, observada na Tabela 5.

Tabela 5 - Distribuição dos Ocupados, segundo posição na ocupação Região Metropolitana de Salvador - 2001-2007

\begin{tabular}{l|c|c|c|c|c|c|c}
\hline \multirow{2}{*}{ Posiçáo na Ocupaçáo } & \multicolumn{7}{c}{ Anos } \\
\cline { 2 - 9 } & $\mathbf{2 0 0 1}$ & $\mathbf{2 0 0 2}$ & $\mathbf{2 0 0 3}$ & $\mathbf{2 0 0 4}$ & $\mathbf{2 0 0 5}$ & $\mathbf{2 0 0 6}$ & $\mathbf{2 0 0 7}$ \\
\hline Ocupados & 100,0 & 100,0 & 100,0 & 100,0 & 100,0 & 100,0 & 100,0 \\
\hline Assalariados (total)* & 61,1 & 59,9 & 60,7 & 59,9 & 61,8 & 62,9 & 64,1 \\
\hline Assalariados setor privado & 46,6 & 45,7 & 46,8 & 46,0 & 48,3 & 49,1 & 50,5 \\
\hline Assalariados com carteira assinada & 34,7 & 33,9 & 35,1 & 34,4 & 36,8 & 37,8 & 40,0 \\
\hline Assalariados sem carteira assinada & 11,9 & 11,8 & 11,7 & 11,6 & 11,5 & 11,3 & 10,0 \\
\hline Assalariados do setor público & 14,5 & 14,2 & 13,8 & 13,9 & 13,4 & 13,7 & 13,6 \\
\hline Autônomos & 21,6 & 23,1 & 23,0 & 25,5 & 22,7 & 21,8 & 21,1 \\
\hline Empregadores & 4,0 & 4,2 & 3,8 & 4,1 & 3,9 & 3,8 & 3,5 \\
\hline Empregados domésticos & 10,8 & 10,1 & 10,1 & 9,7 & 9,4 & 9,3 & 8,1 \\
\hline Outros & 2,5 & 2,7 & 2,4 & 2,7 & 2,2 & 2,2 & 2,5 \\
\hline
\end{tabular}

Fonte: PED/RMS - Convênio SEI, SETRE, UFBA, DIEESE, SEADE, TEM/FAT.

* Inclusive os assalariados que não sabem o tipo de empresa em que trabalham.

Nas suas diversas modalidades, o desemprego também mostra uma tendência à diminuição. Mas ele ainda é bastante elevado - propiciando, nesse aspecto, um triste campeonato nacional à RMS entre as metrópoles brasileiras - $\mathrm{e}$ atinge particularmente alguns segmentos da população. Em 2007, por exemplo, a taxa de desemprego das mulheres alcançava $25,3 \%$, contra $18,4 \%$ dos homens; $22,7 \%$ entre os negros, contra 12,0 dos brancos. Entre os jovens ela se extremava, explicitando as dificuldades de incorporação produtiva das novas gerações, atingindo $49,1 \%$ entre os $10-17$ e $37,9 \%$ entre os $18-24$ anos. Por outro lado, o tempo de procura de trabalho permanece bastante longo, chegando a 6 a 12 meses para 27,0 dos desempregados e a mais de um ano para $32,9 \%$.

Além disso, a expansão das oportunidades de trabalho, foi associada a uma queda das remunerações. Ainda segundo a PED, o rendimento médio real ${ }^{8}$ do

\footnotetext{
${ }^{8}$ Em reais de fevereiro de 2008.
} 
Tabela 6 - Taxas de Desemprego - Regiảo Metropolitana de Salvador - 2001-2007

\begin{tabular}{l|r|r|r|r|r|r|r}
\hline \multirow{2}{*}{\multicolumn{1}{c}{ Tipo de Desemprego * }} & \multicolumn{7}{c}{ Anos } \\
\cline { 2 - 10 } & $\mathbf{2 0 0 1}$ & $\mathbf{2 0 0 2}$ & $\mathbf{2 0 0 3}$ & $\mathbf{2 0 0 4}$ & $\mathbf{2 0 0 5}$ & $\mathbf{2 0 0 6}$ & $\mathbf{2 0 0 7}$ \\
\hline Aberto & 16,4 & 16,3 & 17,0 & 14,9 & 14,2 & 15,0 & 13,8 \\
\hline Outro & 11,1 & 11,0 & 11,0 & 10,6 & 10,2 & 8,6 & 8,0 \\
\hline pelo trabalho precário & 8,0 & 7,8 & 7,6 & 7,6 & 7,4 & 6,6 & 6,2 \\
\hline pelo desalento & 3,1 & 3,2 & 3,4 & 3,0 & 2,8 & 2,0 & 1,8 \\
\hline Total & 27,5 & 27,3 & 28,0 & 25,5 & 24,4 & 23,6 & 21,7 \\
\hline
\end{tabular}

Fonte: PED/RMS - Convênio SEI, SETRE, UFBA, DIEESE, SEADE, TEM/FAT.

* De acordo com os conceitos utilizados pela PED - Pesquisa de Emprego e Desemprego do DIEESE -, são considerados desempregados aqueles "indivíduos que se encontram numa situação involuntária de não-trabalho, por falta de oportunidade de trabalho, ou que exercem trabalhos irregulares com desejo de mudança". Essas pessoas perfazem o que se chama de "desemprego total" na sociedade, total esse que pode ser desagregado em três tipos de desemprego: a) desemprego aberto: "pessoas que procuraram trabalho de maneira efetiva nos 30 dias anteriores ao da entrevista e não exerceram nenhum trabalho nos sete últimos dias"; b) desemprego oculto pelo trabalho precário: "pessoas que realizam trabalhos precários - algum trabalho remunerado ocasional de auto-ocupação - ou pessoas que realizam trabalho nãoremunerado em ajuda a negócios de parentes e que procuraram mudar de trabalho nos 30 dias anteriores ao da entrevista ou que, não tendo procurado nesse período, o fizeram sem êxito até 12 meses atrás"; c) desemprego oculto pelo desalento: "pessoas que não possuem trabalho e nem procuraram nos últimos 30 dias anteriores ao da entrevista, por desestímulos do mercado de trabalho ou por circunstâncias fortuitas, mas apresentaram procura efetiva de trabalho nos últimos 12 meses". (Disponível em: <http://www.dieese.org.br/ped/pedmet.xml> Acesso em: 04 fev. 2006.

conjunto dos ocupados passou de $\mathrm{R} \$ 972,00$ em 1997 para $\mathrm{R} \$ 835,00$ em 2007; entre os brancos, de $R \$ 1,746,00$ para $R \$ 1.406,00$ e entre os negros de $R \$ 783,00$ para $R \$ 747,00$; entre os chefes de família de $R \$ 1.369,00$ para $R \$ 1.042,00$; entre os ocupados com nível médio completo, de $\mathrm{R} \$ 1.243,00$ para $\mathrm{R} \$ 821,00$ e entre os que possuem o curso superior completo de $R \$ 3.095,00$ para $R \$ 2.235,00$.

Considerando o setor de atividade, observa-se que em 1997 o rendimento real médio alcançava $R \$ 1.486,00$ entre os ocupados na indústria, $R \$ 845,00$ no comércio, $\mathrm{R} \$ 1.110,00$ na prestação de serviços, $\mathrm{R} \$ 847,00$ na construção civil e $\mathrm{R} \$ 236,00$ no serviço doméstico. Em 2007 esses valores passaram, respectivamente, para $R \$ 1.086,00, R \$ 632,00, R \$ 957,00, R \$ 710,00$ e $R \$ 308,00$. De acordo com a posição na ocupação, o rendimento em apreço era de $R \$ 1.037$ para os assalariados com carteira assinada, $R \$ 478,00$ para os assalariados sem carteira, $R \$ 1.593,00$ para os assalariados do setor público, $\mathrm{R} \$ 236,00$ para os empregados domésticos. Em 2007 esses números representavam $R \$ 848,00, R \$ 502,00, R \$ 1.515,00, R \$$ $546,00, R \$ 2.318,00$ e $R \$ 308,00$, deixando claro um empobrecimento generalizado, mas que atinge especialmente as classes médias.

Finalmente, a análise das condições de trabalho, pobreza e subsistência na RMS não pode deixar de levar em conta a influência da dimensão espacial - ou seja, das desigualdades intra-metropolitanas - sobre a população.

\section{DESIGUALDADES INTRA-METROPOLITANAS}

Como foi visto em capítulo anterior deste livro, a RMS compreende espaços urbanos que possuem um rico patrimônio histórico e também são modernos, 
dinâmicos, equipados e aprazíveis, constituídos, principalmente, pelos bairros centrais de Salvador e pela Orla Atlântica que vai até Lauro de Freitas, onde se concentram a moradia das camadas de alta e média renda, atividades econômicas e espaços turísticos. E, também outras cidades distintas e precárias no Miolo, no Subúrbio Ferroviário e nos demais municípios, afetados por várias ordens de carências.

Os contornos e as diferenças dessas "cidades" são bem evidentes, por exemplo, no plano educacional. $O$ analfabetismo funcional tem uma freqüência inexpressiva no centro de Salvador e por toda a Orla Atlântica (onde ficam áreas superiores ou média-superiores como Nazaré, Canela, Campo Grande, Barra, Horto Florestal, Pituba, Itaigara, Caminho das Árvores ou Vilas do Atlântico), assim como na área do Parque Verde, em Camaçari. Mas essa freqüência cresce no Miolo e nas franjas de Salvador, no centro de Simões Filho e de Camaçari, atingindo um patamar superior a 30\% em áreas como o Nordeste de Amaralina ou o Bairro da Paz, em Salvador, no interior de Lauro de Freitas, Simões Filho e Camaçari e nos municípios de São Francisco do Conde, Itaparica e Vera Cruz (Mapa 1).

\section{Mapa 1 - Analfabetismo funcional (percentual) - Região Metropolitana de Salvador - 2000}

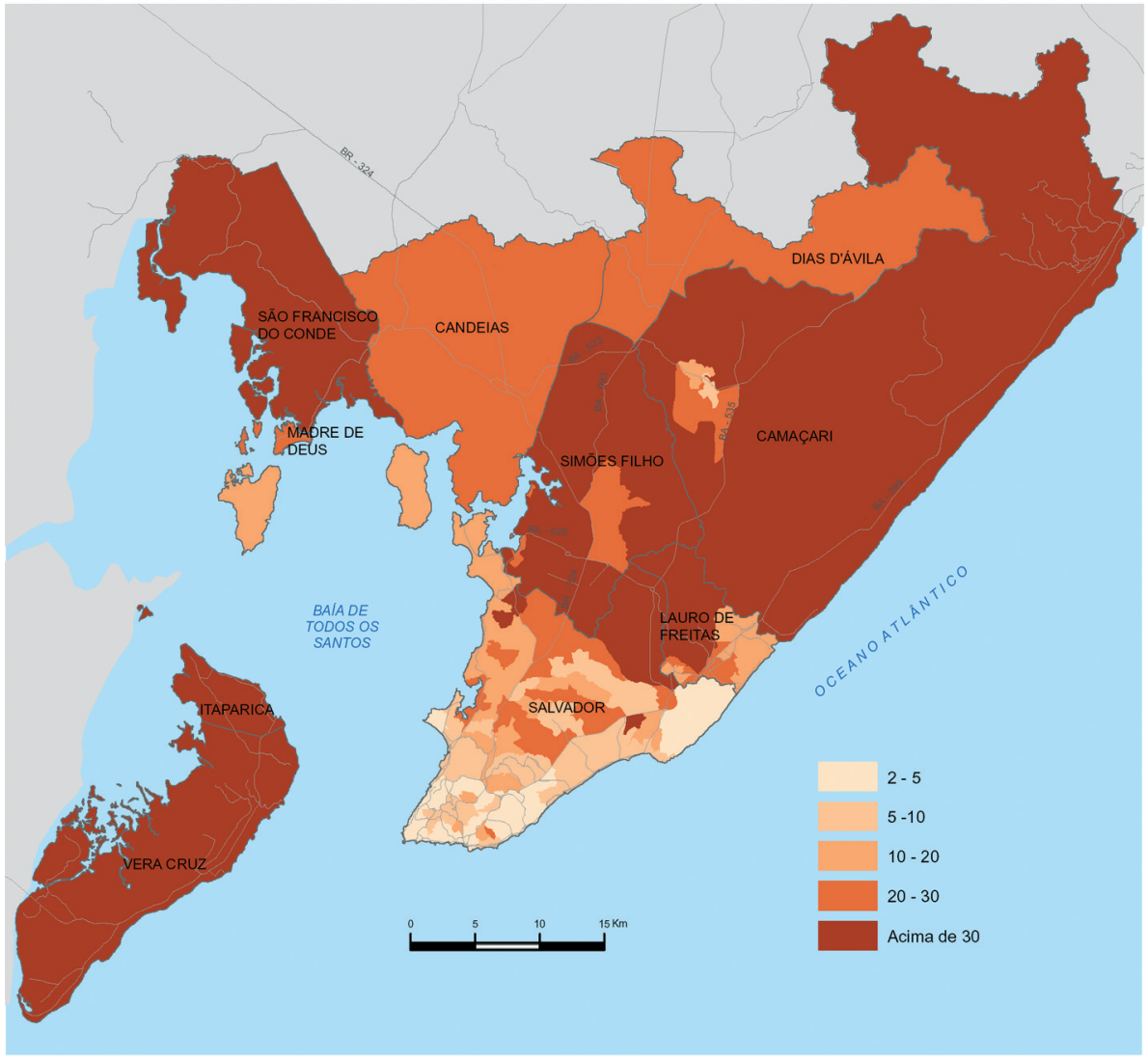

Fonte: : Censo Demográfico, 2000. Elaboração dos organizadores. 
A freqüência à escola fundamental, praticamente universalizada, mostravase um pouco mais restrita no Miolo e nas bordas de Salvador (mais precisamente em localidades como o Bairro da Paz, Nova Brasília, Jardim das Margaridas, Valéria e Cajazeiras) e no interior de Camaçari, como ilustra o Mapa 2.

\section{Mapa 2 - Freqüência escolar entre 7-14 anos (percentual) - Região Metropolitana de Salvador - 2000}

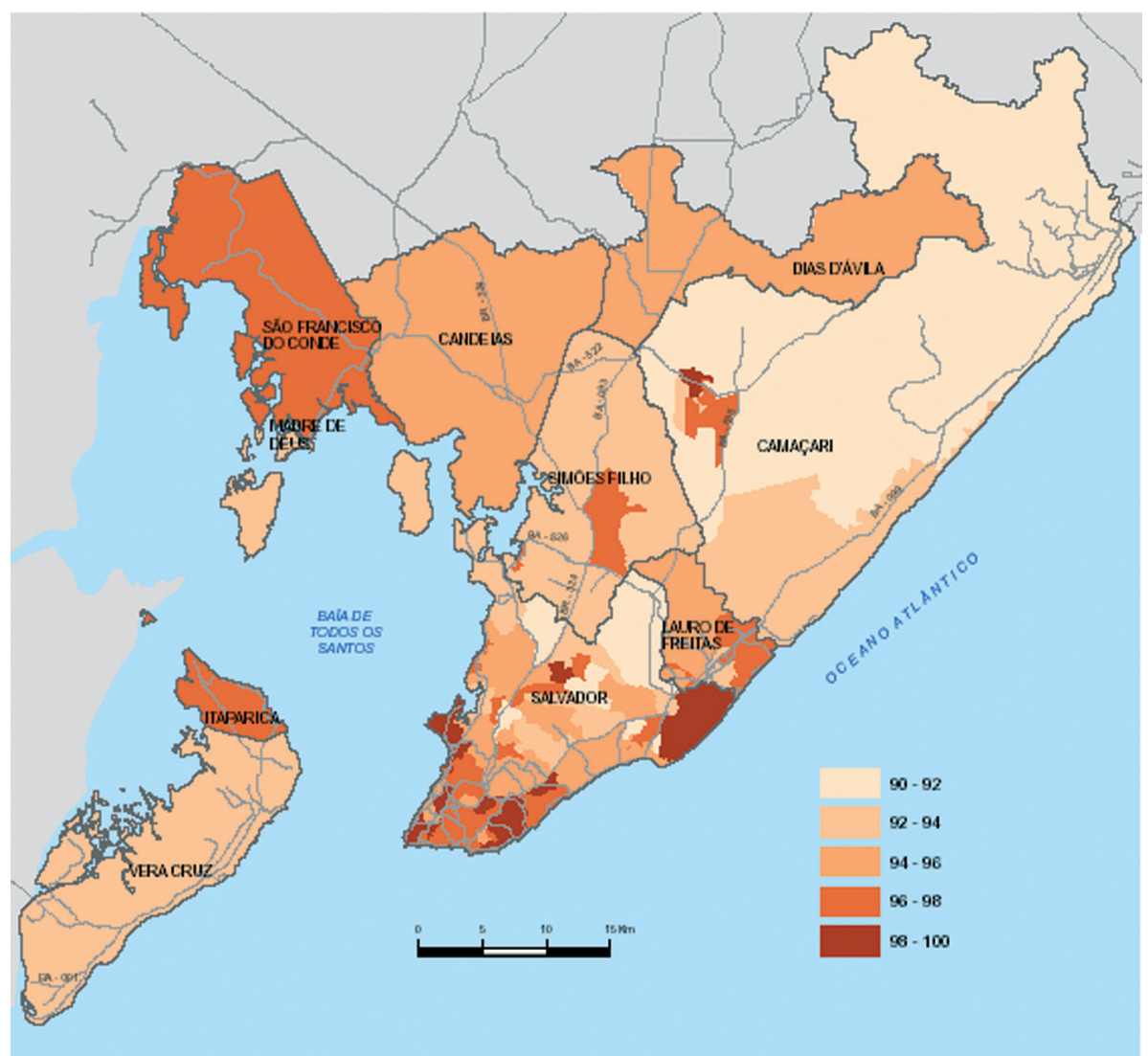

Já a eficiência com que as crianças são atendidas é bem mais variada, como indicam os números relativos ao atraso escolar da população entre 7-14 anos, os anos de estudo da população entre 10-14 anos e, principalmente, a adequação entre idade e série constatada. Se, em Salvador, $26,96 \%$ das crianças, na faixa dos 7-14 anos, e 38,56\%, na faixa dos 10-14, apresentavam mais de um ano de atraso escolar, em 2000, em Madre de Deus esses números correspondiam a 30,54\% e 45,03\%; em Lauro de Freitas, a 32\% e 46,48\%; em Camaçari, a 32,28\% e 46,75\%; em Simões Filho, a 32,89\% e 47,97\%; em Dias D'Ávila, a 33,53\% e 48,61\%; em São Francisco do Conde, a 34,4\% e 52,61\%; em Candeias, a 35,69\% e 49,23\%; em Itaparica, a 36,32\% e 53,5\%; por fim, na situação mais desfavorável, 
encontrava-se Vera Cruz, com taxas de, respectivamente, $40,98 \%$ e $59,52 \%$. E se $43,69 \%$ das crianças, entre 10-14 anos, tinham menos de quatro anos de estudo em Salvador, no ano 2000, esse percentual se elevava para 49,26\% em São Francisco do Conde, 49,85\% em Camaçari, 51,02\% em Dias D'Ávila, 51,06\% em Madre de Deus, 51,77\% em Simões Filho, 52,13\% em Candeias, 52,38\% em Lauro de Freitas, $55,17 \%$ em Vera Cruz e $55,53 \%$ em Itaparica.

Nos espaços classificados como superiores e médio superiores de Salvador, a exemplo de Barra e da Barra Avenida, da Graça, do Jardim Apipema, Chame-Chame, Pituba ou Stela Maris, registrava-se uma adequação entre idade e série acima de $80 \%$, na faixa dos 7-14 anos. Já nos espaços populares, essa adequação se reduzia, chegando a níveis críticos em locais como Pau da Lima, Cajazeiras, Bairro da Paz e Itinga, Simões Filho, Camaçari, Dias D’Ávila e Vera Cruz (Mapa 3 e 4).

Mapa 3 - Adequação idade-série 7 a 14 (percentual) - Salvador - 2000

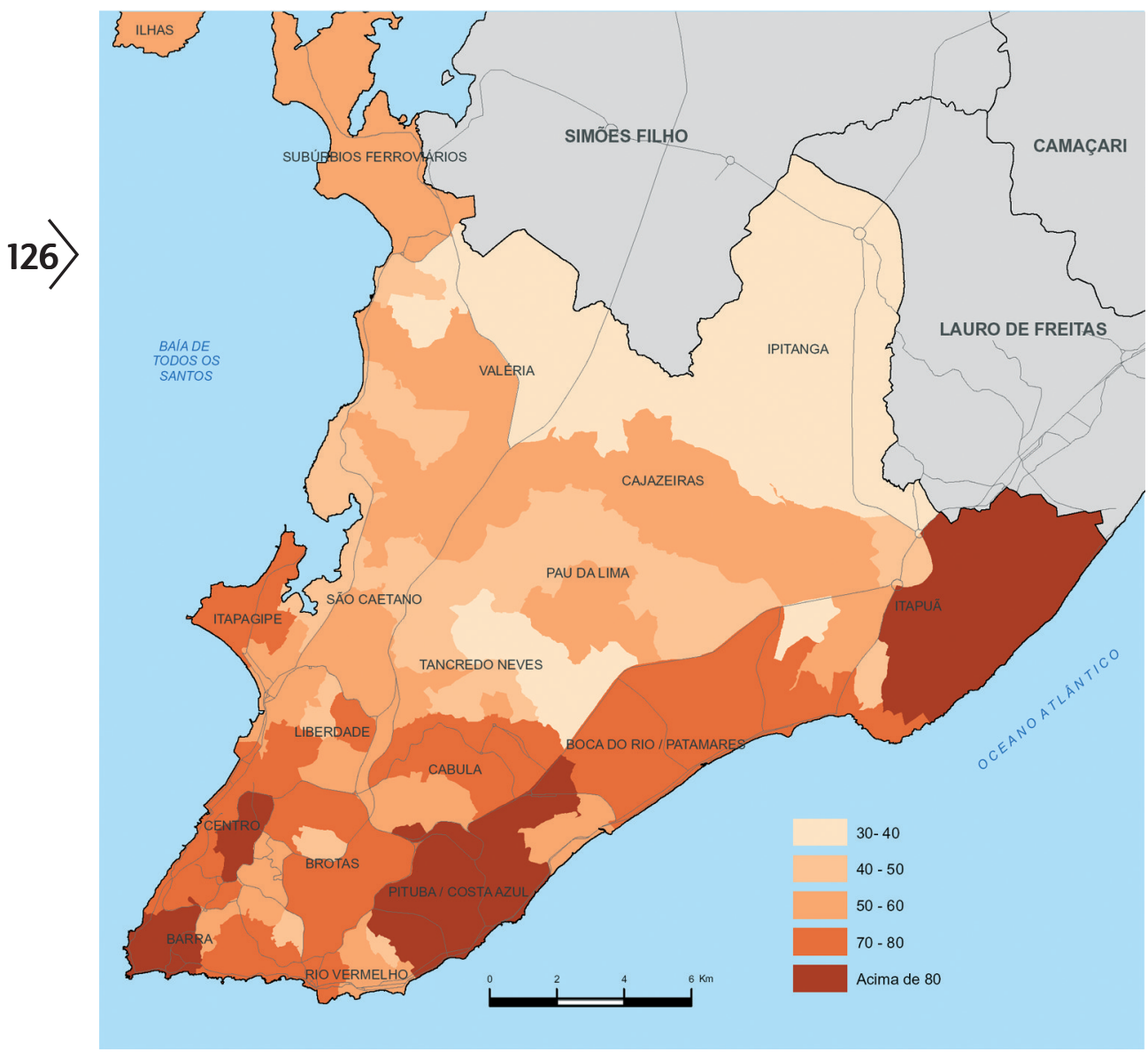

Fonte: : Censo Demográfico, 2000. Elaboração dos organizadores. 


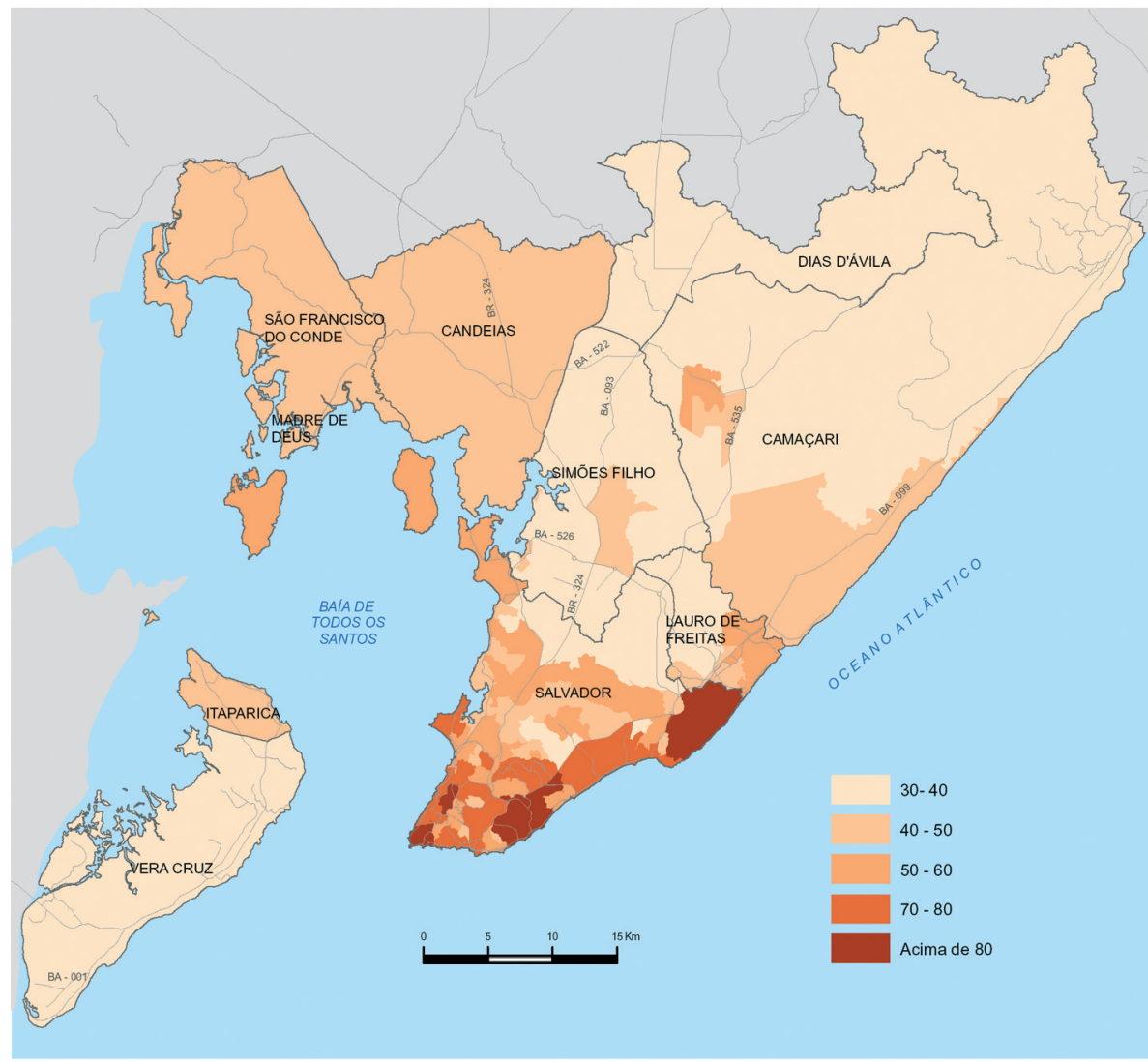

Fonte: : Censo Demográfico, 2000. Elaboração dos organizadores.

0 mesmo padrão de desigualdade transparece através do nível de instrução dos responsáveis pelos domicílios, identificados pelo Censo de 2000. Aqueles com mais baixo nível (ou seja, com menos de um ou com um a sete anos, o que corresponde, aproximadamente, ao primeiro grau) estão espraiados por toda a cidade de Salvador, mas se acentuam nos espaços de base popular, ou popular inferior. Já os que possuíam 15 anos ou mais de instrução residiam, basicamente, no centro ou na Orla de Salvador e de Lauro de Freitas, conforme mostra o Mapa 5.

Confirmando esse padrão, Almeida e Damasceno (2005) constataram que os trabalhadores com apenas o primeiro grau incompleto perfaziam $38,4 \%$ dos ocupados na região administrativa de Tancredo Neves, 35,0\% em Pau da Lima, 43,3\% em Ipitanga, 44,6\% em Valéria e 78,0\% nos Subúrbios Ferroviários, em 20032004, segundo informações da PED. Em contrapartida, nas regiões da Barra e da Pituba/Costa Azul os ocupados com o terceiro grau completo representavam 40,9\% e $45,6 \%$, respectivamente. E, como as condições educacionais e ocupacionais são estreitamente articuladas, a chamada "informalidade" também se concentrava em 
TRABALHO, RENDA E POBREZA NA REGIÃO METROPOLITANA DE SALVADOR

Mapa 5 - Nível de instrução do responsável pelo domicílio (percentual) - Salvador 2000

Sem instrução

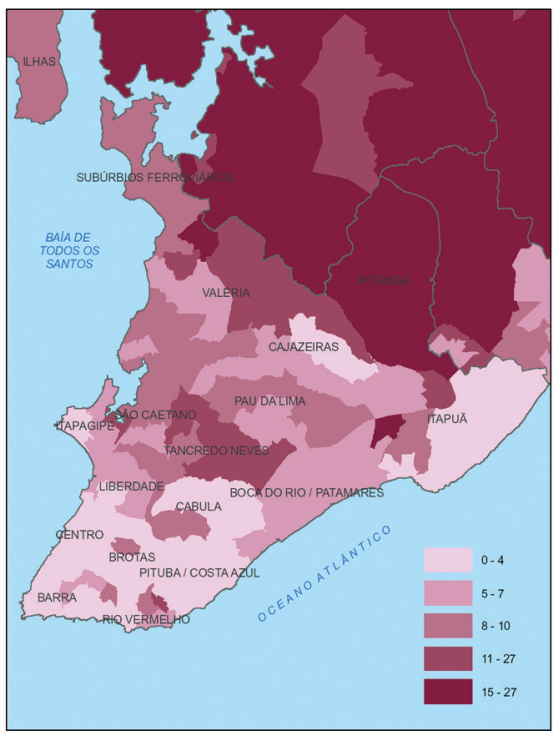

8 a 14 anos de instrução

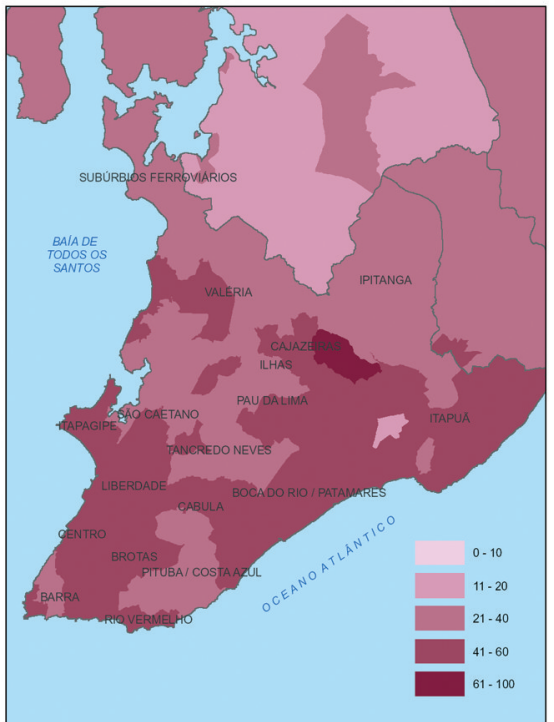

Fonte: IBGE Censo 2000
1 a 7 anos de instrução

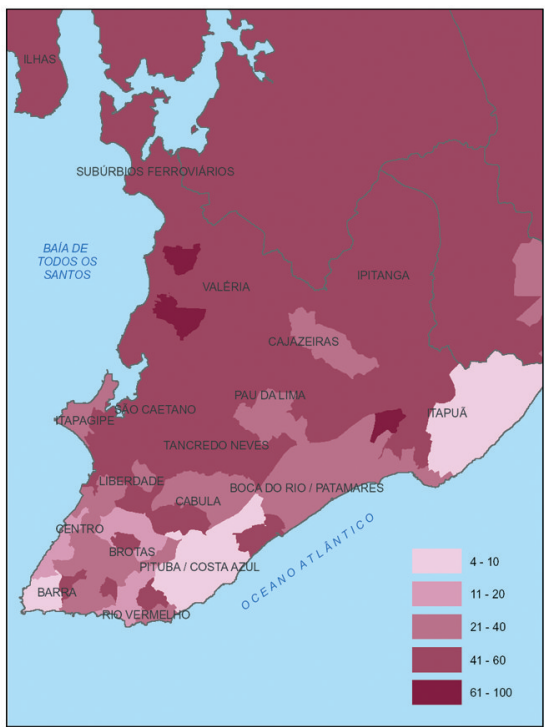

Mais de 15 anos de instrução
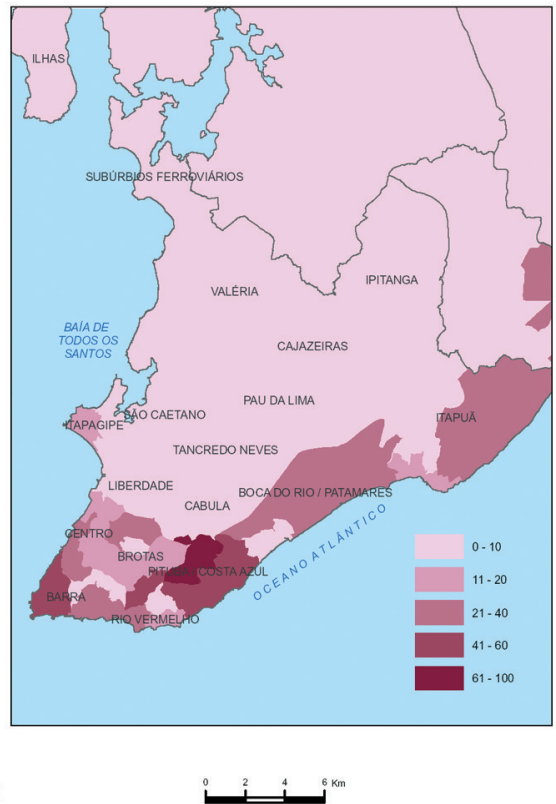

Fonte: : Censo Demográfico, 2000. Elaboração dos organizadores. 
bairros como Tancredo Neves (49,0\% dos ocupados), São Caetano (50,7\%), Valéria $(51,4 \%)$ e Ipitanga (60,5\%), assim como nos Subúrbios Ferroviários (51,6\%). 0 desemprego aberto e total era igualmente mais grave nesse tipo de área, com destaque, mais uma vez, para os Subúrbios Ferroviários, Valéria, Ipitanga, São Caetano e Cajazeiras.

Não existem dados disponíveis sobre o desemprego nos demais municípios da RMS. Sabe-se, porém, que ele é elevado e muitas vezes encoberto pelo exercício de ocupações precárias e mal remuneradas, o que contribui para explicar a dispersão espacial da riqueza e da pobreza na RMS. Conforme assinalado em capítulo anterior a riqueza está concentrada em Salvador, notadamente na Barra, na Pituba e nas suas adjacências, assim como na orla marítima de Lauro de Freitas, onde se encontram Vilas do Atlântico e diversos condomínios fechados. Já a pobreza é mais intensa em São Francisco do Conde, em Itaparica e Vera Cruz, em Simões Filho e no interior de Lauro de Freitas e Camaçari, assim como em certos locais de Salvador, como Alagados, São João, Boa Vista do Lobato, Periperi, Fazenda Coutos, Bairro da Paz, Águas Claras e Cajazeiras, como evidenciam os Mapas 6, 7 e 8.

Esse conjunto de dados é ilustrativo da segmentação social existente em Salvador e em sua Região Metropolitana, onde coexistem espaços bem equipados, afluentes e aprazíveis, ao lado do que se poderia classificar como "territórios penalizados e penalizadores, situados no mais baixo nível da estrutura urbana e portadores de um estigma residencial poderoso" (Wacquant, 2001, p.120), que contribuem para a reprodução da pobreza e para a sua cristalização.

Diversos autores têm analisado esses "efeitos do lugar" de moradia, destacando a influência do território sobre as desigualdades de acesso ao mercado de trabalho e a bens e serviços urbanos, sobre a constituição de redes e sobre 0 acúmulo de capital cultural e social, que interferem significativamente sobre as oportunidades de integração, sobre as condições de vida e sobre a exposição a situações de risco e de vulnerabilidade social. (Bourdieu, 1999; Kaztman, 2001; Kaztman; Wormald, 2002; Ribeiro, 2005; Marques; Torres, 2005).

No caso do Brasil, uma vasta literatura tem se debruçado sobre as favelas e periferias e ressaltado a sua destituição. Se hoje ela é menos intensa que no passado, uma vez que a disponibilidade de infra-estrutura e serviços públicos vem se ampliando nas cidades, chegando a esses locais (inclusive pela luta dos moradores) e tornando os territórios de pobreza mais heterogêneos, persistem desigualdades expressivas em termos do acesso e, sobretudo, da qualidade desses bens.

Além disso, as atividades produtivas e os postos de trabalho se concentram nos distritos centrais e mais dinâmicos das cidades, sendo, geralmente, reduzidos nas áreas em questão. Assim, a distância, as dificuldades de transporte ${ }^{9}$ e o próprio

\footnotetext{
${ }^{9}$ Pesquisas sobre as periferias urbanas têm ressaltado como seus moradores são atingidos pela carência de transportes públicos, pelo seu preço e pelo desgaste dos longos percursos para atividades cotidianas, como a escola e o trabalho. No caso de Salvador, esses problemas são agravados pela pobreza, uma vez que, segundo estimativas da Agência Nacional de Transportes Públicos -ANP, baseadas em informações para 2004, do
} 
Mapa 6 - Renda do responsável pelo domicílio - Salvador 2000

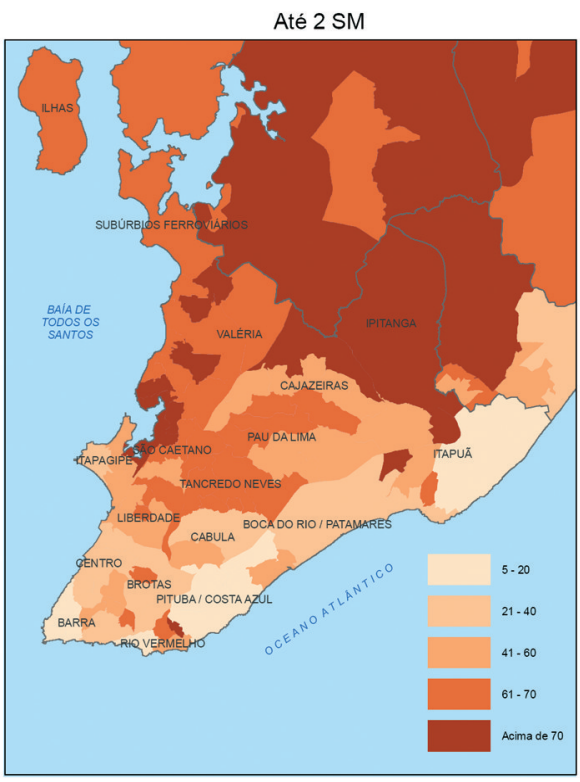

De 5 a 10 SM
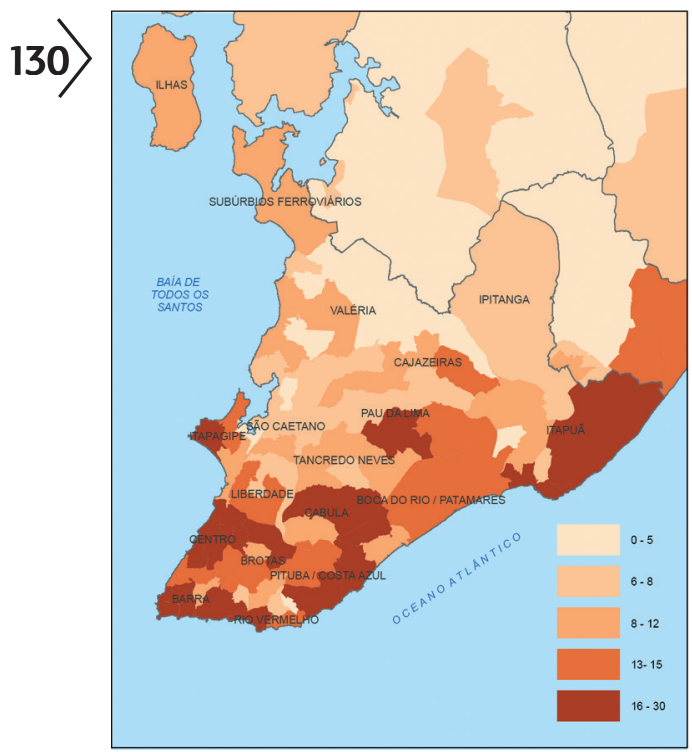

Fonte: IBGE. Censo 2000

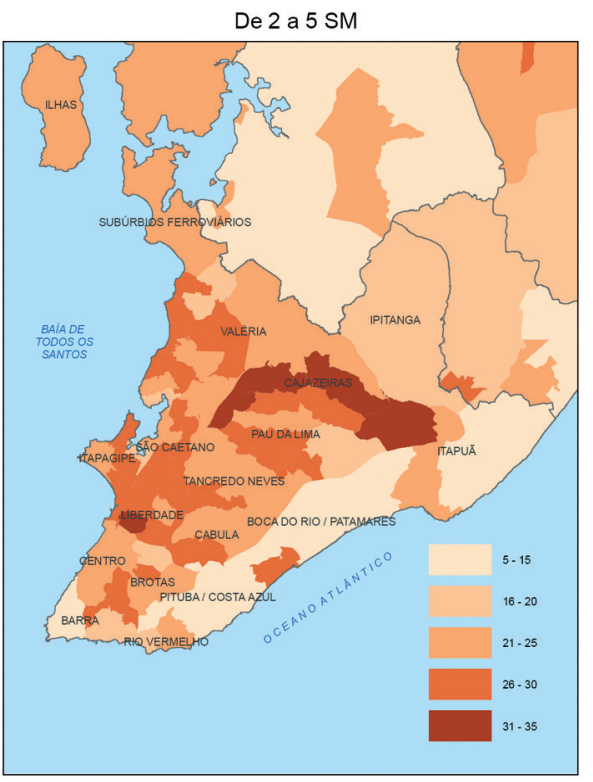

De 10 a 20 SM

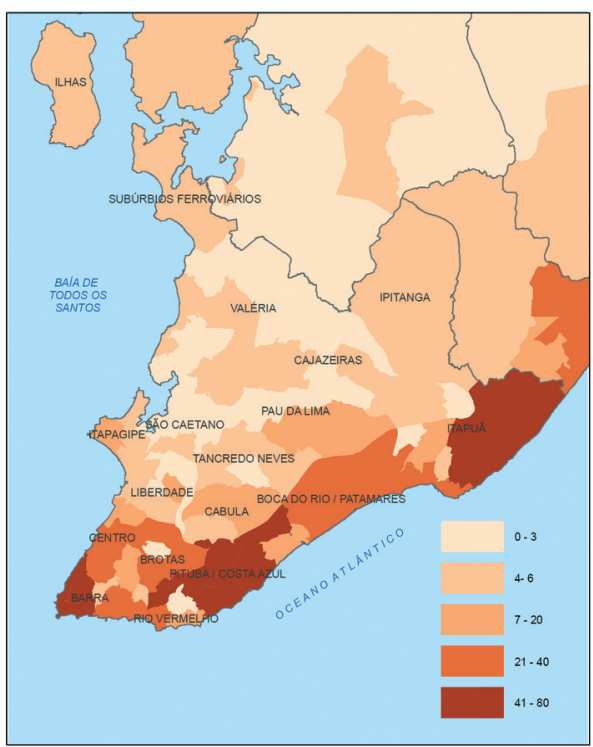

IPEAIBGE, 35\% da população de Salvador (correspondendo a 921.140 pessoas) não pode arcar com o custo da passagem de ônibus. Com isso, essas pessoas permanecem prisioneiras de estreitos limites de deslocamento ou são obrigadas a fazer longos percursos a pé, com um enorme desgaste físico e prejuízos para a saúde, como mostram depoimentos coletados por uma reportagem do jornal A Tarde, publicada em 31 de julho de 2005. 
Mapa 7 - Famílias com renda per capita mensal até meio salário mínimo (percentual) Salvador - 2000

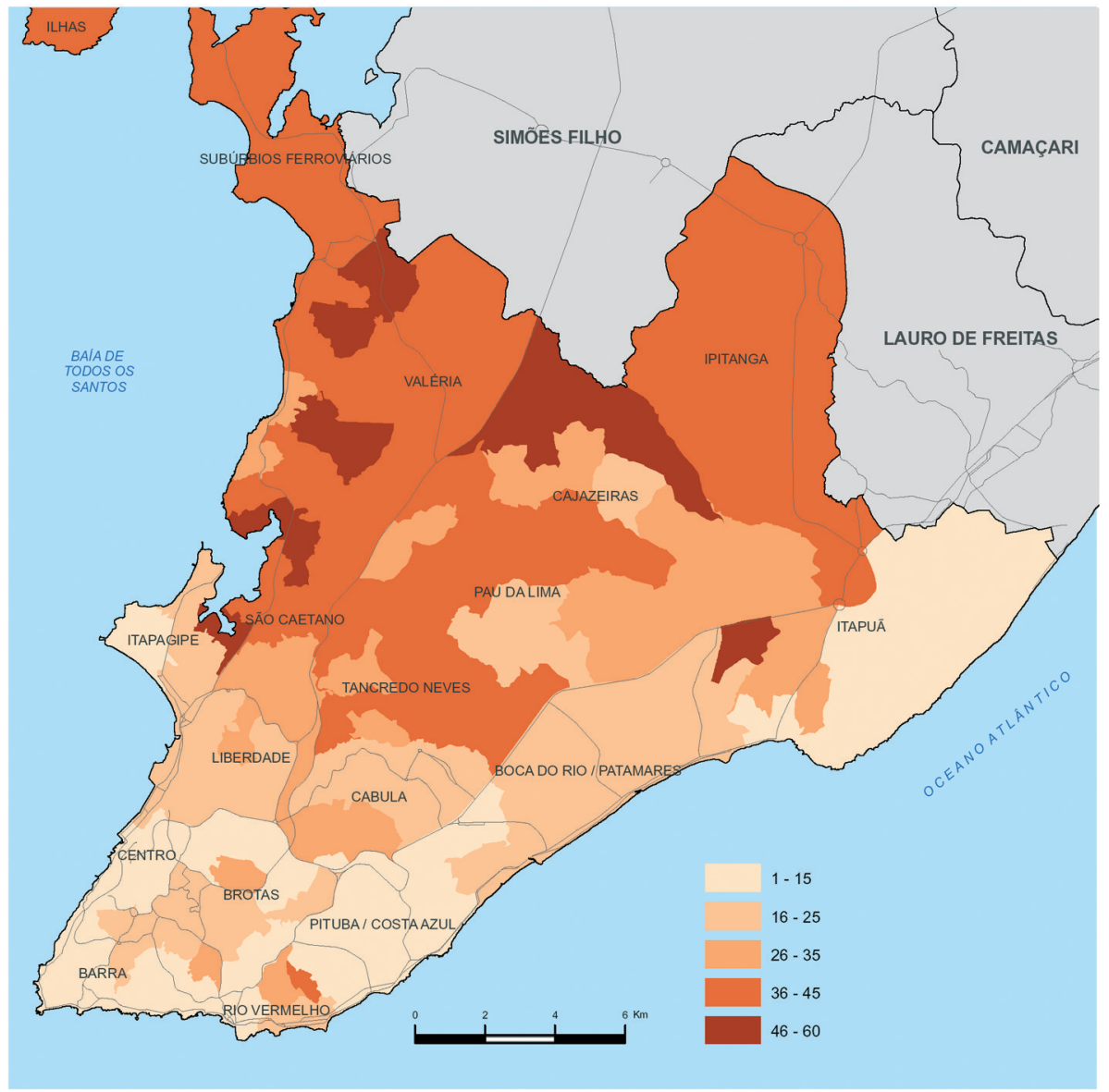

Fonte: : IBGE, Censo Demográfico, 2000. Elaboração dos organizadores.

estigma de residir em espaços considerados como territórios de deterioração, marginalidade e delinqüência, onde apenas o refugo da sociedade aceita ficar, somam-se aos baixos níveis educacionais e a outros atributos adversos dos moradores dessas áreas, reduzindo suas oportunidades de ocupação, obtenção de renda e de mobilidade social.. A homogeneidade e 0 isolamento social dos grandes bairros pobres atuam também nesse sentido, limitando as oportunidades de contatos e interações informais com pessoas de outras classes, fontes de informações, contatos e facilidades para a busca de trabalho e serviços públicos, para a resolução de problemas do cotidiano e para aquisição de "ativos' que possam reduzir a pobreza e a vulnerabilidade social.

Estudos como os de Kaztman (2001), Wacquant (2001) e Ribeiro (2005), têm ressaltado como o empobrecimento das redes de solidariedade e reciprocidade 
Mapa 8 - Famílias com renda per capita até meio salário mínimo (percentual)

Região Metropolitana de Salvador - 2000

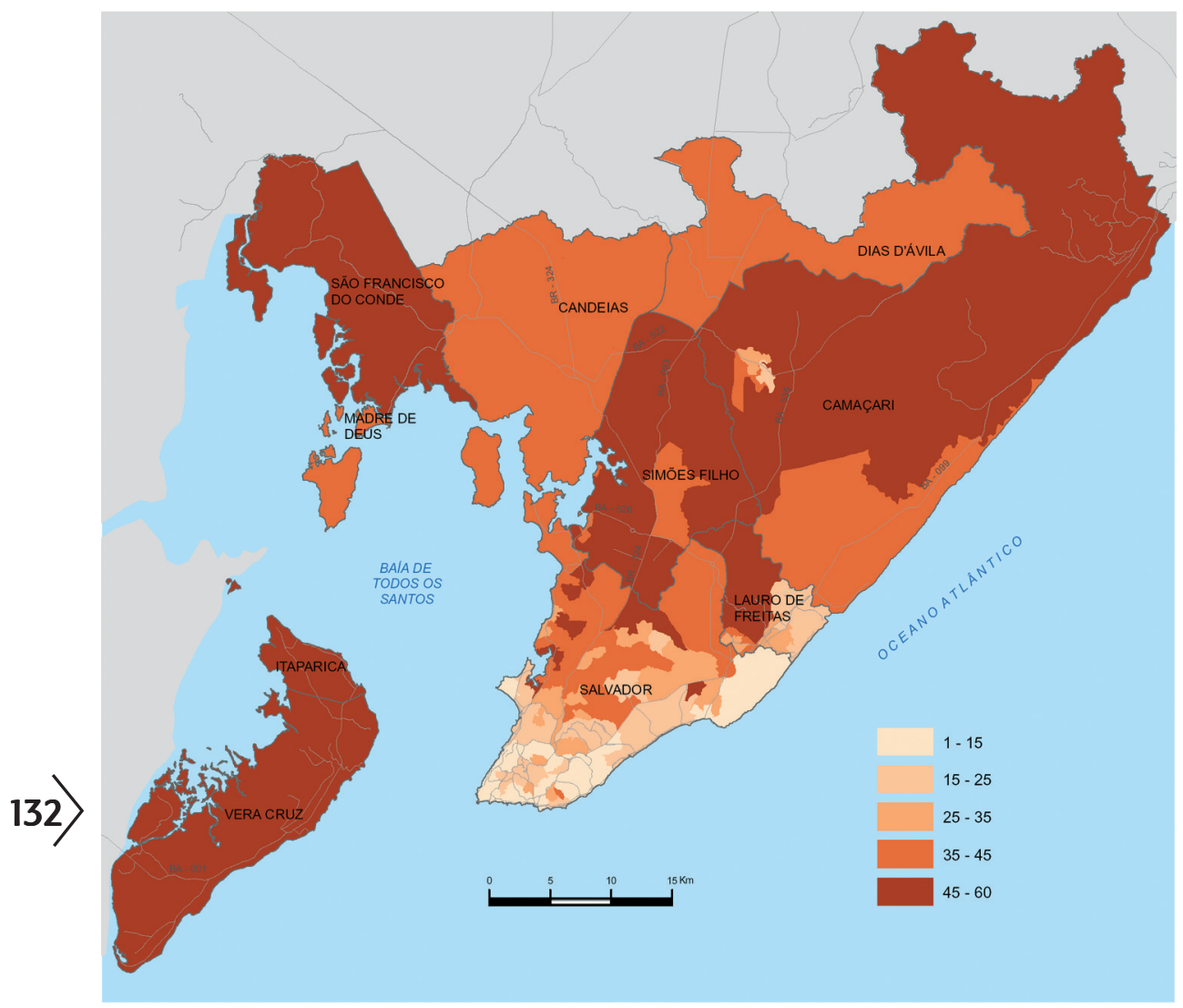

Fonte: : IBGE, Censo Demográfico, 2000. Elaboração dos organizadores.

está entre os efeitos mais perversos da reestruturação do mercado de trabalho e dos processos de segregação e segmentação urbanas, com a articulação de segmentação do mercado de trabalho à segmentação residencial. Na medida em que essas redes passam a estar centradas na família e em alguns poucos vizinhos, pessoas que compartilham uma situação similar de desemprego, ocupação precária e pobreza não têm maiores possibilidades de ajudar seus familiares e amigos através de informações e contatos que funcionam como pontes para o acesso a recursos localizados fora da vizinhança, conforme comprovado por Arantes, (2007) em Salvador. Além disso, a estigmatização que se abate sobre certos bairros populares pode dar origem a práticas de distanciamento, evitação, reconstituição e elaboração de "infradiferenças" ou micro-hierarquias entre seus moradores, exacerbando processos de diferenciação interna que conspiram para diminuir a confiança inter-pessoal e o senso de coletividade, acentuando a desestruturação social dessas áreas.

Ademais, ainda que não se possa considerar a existência de uma 
"ecologia" da pobreza, estudos recentes têm ressaltado como crescer em áreas assim, onde a mesma encontra-se altamente concentrada, exerce efeitos negativos consideráveis no que se refere ao avanço educacional, gravidez na adolescência e envolvimento com a criminalidade, dada á expansão territorializada do tráfico de drogas, entre outras condições (Kaztman, 2001; Ribeiro, 2005; Torres; Ferreira; Gomes, 2005).

Baseando-se em estudos efetuados na Região Metropolitana de São Paulo, Torres, Ferreira e Gomes (2005), assinalam que a performance escolar dos alunos (medida pelas notas de Português e Matemática, obtidas na $8^{\mathrm{a}}$ série do ensino fundamental) sofre uma forte influência do nível socioeconômico médio da escola onde estudam, ao lado de características como sexo, raça, renda e escolaridade dos pais. Como ressaltam os autores, ao entrar no sistema escolar, as crianças já são desiguais. Freqüentar escolas homogêneas, cujos alunos têm 0 mesmo perfil (sendo oriundos de famílias pobres e de baixa escolaridade), tende a afetar negativamente 0 seu desempenho e a restringir suas oportunidades educacionais, contribuindo para a persistência ou a própria elevação das desigualdades originais. Ainda que estudos dessa ordem não tenham sido realizados em Salvador, indícios como o número de jovens que não trabalham nem estudam e o desempenho escolar observado nas áreas pauperizadas do centro e da periferia apontam nessa direção, mostrando a importância do território na reprodução e cristalização da pobreza e da vulnerabilidade.

Finalmente, não se pode esquecer que o grau e a superposição de carências, associado a fatores como a territorialização do tráfego de drogas, vêm elevando o grau de conflitividade e de violência nos bairros populares, atingindo especialmente os seus moradores jovens. Na capital baiana, levantamento efetuado pelo DEPOM/CCV sobre o número de assassinatos em 100 bairros de Salvador, constatou que 19 deles respondiam por $39,1 \%$ do total de homicídios ocorridos em 2005. Tratava-se de bairros pauperizados como Uruguai, Águas Claras, Paripe, Lobato, Periperi, Pirajá, São Caetano, Valéria, Cajazeiras, São Cristóvão, Liberdade, Nordeste de Amaralina, Sussuarana, Castelo Branco e IAPI (A Tarde, 2005, p.19). Nos Subúrbios Ferroviários, onde residem cerca de 500 mil pessoas nas condições apontadas ao longo deste texto, um jovem estava sendo morto a cada três dias, em 2005. Além das condições de vida, as desigualdades associadas ao local de moradia estão interferindo sobre a própria preservação da vida nas regiões metropolitanas brasileiras, como foi constatado no caso de Salvador.

\section{REFERÊNCIAS}

ALMEIDA, Paulo Henrique de; DAMASCENO, Luciano. Perfil socioeconômico do trabalhador informal de Salvador - 2005. Relatório parcial. Salvador: Prefeitura Municipal, Fundação Mário Leal Ferreira, set. 2005. $94 \mathrm{p}$. 
. Aeconomia de Salvador e a formação de sua Região Metropolitana. In: CARVALHO, Inaiá M. M. de; PEREIRA, Gilberto Corso (Org.). Como Anda Salvador. Salvador, EDUFBA, 2006, p. 11-53.

ALONSO, Luiz Henrique. Trabajo y pos-modernidad: el empleo débil. Madrid: Editorial Fundamentos, 2000. $261 \mathrm{p}$.

ARANTES, Rafael. Enquanto isso, lá no miolo da cidade. 2007. Monografia (Conclusão Curso de Ciências Sociais) - Universidade Federal da Bahia, Salvador, 2007.

BORGES, Ângela Maria Carvalho. Desestruturação do mercado de trabalho e vulnerabilidade social: a região metropolitana de Salvador na década de 90. 2003. Tese (Doutorado em Ciências Sociais) - Faculdade de Filosofia e Ciências Humanas da UFBA, Salvador, 2003.

; FILGUEIRAS, Luis A. M. Mercado de trabalho nos anos 90: o caso da RMS. Bahia Análises \& Dados, Salvador, SEI, v.5, n.3, p.30-63, 1995.

BORJA, Jordi; CASTELS, Manuel. Local e global. La gestión de las ciudades en la era de la información. Madrid: Taurus, 1997.

BOURDIEU, Pierre (Coord.) Efeitos de lugar. In: A miséria do mundo. 3.ed. Petrópolis: Vozes, 1999. p.159-214.

CARVALHO, Inaiá M. M. de; CODES, Ana Luiza Machado. Condições ocupacionais, pobreza e desigualdades. In: ; PEREIRA, Gilberto Corso (Org.). Como Anda Salvador. Salvador, EDUFBA, 2006. p.109-135.

;ALMEIDA, Paulo Henrique; AZEVÊDO, José Sérgio G. Dinâmica metropolitana e estrutura social em Salvador. Tempo Social: revista de Sociologia da USP. São Paulo, v.13, n.2, p.89-114, 2001.

; SOUZA, Guaraci A. A. de. A produção não capitalista no desenvolvimento capitalista de Salvador. In: SOUZA, Guaraci A. A. de; FARIA, Vilmar (Org.). Bahia de todos os pobres. São Paulo: CEBRAP, 1980. p.71-102.

DIEESE. Conceito de desemprego. Disponível em: <http://www.dieese.org.br/ped/ pedmet.xml>Acesso em: 04 fev. 2006.

FERNANDES, Cláudia Monteiro. Juventude em transição para o mundo do trabalho. 2006. 121 f. Dissertação (Mestrado) - Programa de Pós-Graduação em Ciências Sociais da Universidade Federal da Bahia. Salvador, 2006.

FOLHA DE SÃO PAULO, 29 jan. 2006. p.B1, B3.

IBGE. Censo demográfico. Rio de Janeiro, 1991.

. Censo demográfico. Rio de Janeiro, 2000.

Sintese dos indicadores sociais 2003. Rio de Janeiro, 2004.

KAZTMAN, Ruben. Seducidos y abandonados: el aislamiento social de los pobres urbanos. Revista da CEPAL, Santiago do Chile, n. 75, dez., 2001.

; WORMALD, Guillermo (Coord.). Trabajo y ciudadanía. Los cambiantes rostros de la integración y exclusión social en cuatro áreas metropolitanas de América Latina. Santiago do Chile: [s.n.], 2002.

MACHADO DA SILVA, L. A. Da informalidade à empregabilidade. Caderno $\mathrm{CRH}$ : revista do Centro de Recursos Humanos da UFBA, Salvador, n.37, p.81-109, jul./dez., 2002.

MARQUES, Eduardo; TORRES, Haroldo. (Org.). São Paulo: segregação, pobreza e desigualdades sociais. São Paulo: Editora SENAC, 2005. 329 p.

MATTOS, Carlos A. Redes, nodos e cidades: transformação da metrópole latino-americana. In: RIBEIRO, Luiz César Q. (Org.). Metrópoles: entre a coesão e a fragmentação, a cooperação e o conflito. São Paulo: Ed. Perseu Abramo; Rio de Janeiro: FASE/ Observatório das Metrópoles, 2004.

MOURA, Rosa; DELGADO, Paulo; DESCHAMPS, Marley; CARDOSO, Nelson A. A. A realidade das áreas metropolitanas e seus desafios na federação brasileira: diagnóstico socioeconômico e da estrutura de 
gestão. In: SEMINÁRIO INTERNACIONAL DESAFIO DA GESTÃO DAS REGIÕES METROPOLITANAS EM PAÍSES FEDERADOS. Brasília, 2004.

NUN, José. Marginalidad y exclusión social. Buenos Aires: Fondo de Cultura Económica, 2001. 321 p. POCHMANN, Márcio. Mercado de trabalho: o que há de novo no Brasil. Parcerias Estratégias, Brasília, n.22, p.121-142, 2006.

RIBEIRO, Luiz César Q. Segregación residencial y segmentación social: el efecto vecindario en la reproducción de la pobreza en las metrópolis brasileñas. In: LEGUIZAMON, Sonia Álvarez (Comp.). Trabajo y producción de la pobreza en Latinoamérica y el Caribe. Buenos Aires: CLACSO, 2005. p.137-155. . (Org.). Metrópoles. Entre a coesão e a fragmentação, a cooperação e o conflito. São Paulo: Ed. Fundação Perseo Abramo; Rio de Janeiro: FASE/Observatório das Metrópolis, 2004.

SASSEN, Saskia. The global city: New York, London, Tokyo. New Jersey. Princeton: University Press, 1991.

TORRES, Haroldo; FERREIRA, M. Paula; GOMES, Sandra. Educação e segregação social: explorando o efeito das relações de vizinhança. In: MARQUES, Eduardo; TORRES, Haroldo (Org.). São Paulo: segregação, pobreza e desigualdades sociais. São Paulo: Editora SENAC, 2005. p.123-141.

VELTZ, Pierre. Mondialization, villes et territories. L'economie del archipel. Paris: Press Universitaire de France, 1996.

WACQUANT, Lóic. Os condenados da cidade: estudos sobre marginalidade avançada. Rio de Janeiro: REVAN; FASE, 2001. 



\title{
HABITAÇÃO E INFRA-ESTRUTURA URBANA EM SALVADOR E REGIÃO METROPOLITANA
}

\author{
Gilberto Corso Pereira*
}

O processo histórico de crescimento das cidades brasileiras tem levado à configuração de um quadro de extremas desigualdades sociais e concentração de renda, tendo como resultado um cenário urbano de intensa segregação espacial. Esta segregação se traduz em termos físicos pelos fortes contrastes entre o que se pode considerar "cidade formal" - caracterizada por áreas com boa oferta de infraestrutura, reguladas pelo mercado imobiliário e normalmente atendendo a legislação urbanística no que diz respeito as condições da edificação e ao uso do solo - e, por outro lado, pela "cidade informal" - caracterizada pela implantação de loteamentos irregulares e clandestinos, bem como invasões de áreas públicas e privadas ocupada pela população de baixa renda em decorrência da impossibilidade de acesso ao mercado imobiliário por esta parcela da população e da pouca efetividade das políticas habitacionais de interesse social (ver dentre outros, Brandão, 1981, Pereira, 1989, Souza, 2000 e 2002, Marques e Torres, 2005).

Salvador, como as demais capitais brasileiras, não foge muito deste padrão de urbanização, com grandes desafios para a efetividade do controle, ordenamento do uso e ocupação do solo e com dificuldade para assegurar a prestação de serviços públicos a um conjunto considerável de seus habitantes mais pobres.

Com uma população de 2,5 milhões de habitantes no censo de 2000 , Salvador acumula um déficit quantitativo que já ultrapassa o patamar de 100 mil moradias, sendo mais de 82 mil para a faixa de renda de até 3 salários mínimos (coabitação, domicílio improvisado e/ou rústico, cômodo alugado ou cedido),

\footnotetext{
* Professor da Faculdade de Arquitetura da Universidade Federal da Bahia, do Programa de Pós-Graduação em Arquitetura e Urbanismo e do Mestrado em Geografia da Universidade Federal da Bahia.

O trabalho revê, atualiza e traz novos dados e informações, constituindo-se em nova versão do capítulo elaborado para a primeira edição "Condições de moradia e Infra-Estrutura Urbana”, pelo autor e porAngela Gordilho Souza.
} 
segundo dados da Fundação João Pinheiro. Além do déficit quantitativo, a cidade apresenta 0 déficit qualitativo em torno de 400 mil domicílios (domicílios que requerem melhorias de infra-estrutura no domicílio e na ocupação), o que equivale dizer que cerca de $60 \%$ da população tem suas moradias em assentamentos precários, de ocupação desordenada. Nesse sentido, além da necessidade de novas unidades habitacionais decorrentes do crescimento populacional, o déficit habitacional constituído historicamente, abrange as deficiências ambientais e de infra-estrutura física e social (Souza, 2000).

A trajetória de Salvador e dos municípios que hoje compõem a sua região metropolitana foi marcada por décadas de estagnação econômica, pela pobreza da população e por um processo de modernização excludente, que se refletiu na sua conformação urbana, nos problemas de moradia e na disponibilidade de infraestrutura e serviços urbanos.

Desde a década de 1940 que, em Salvador, o acesso à moradia da população de baixa renda esteve vinculado a processos de parcelamento improvisado e auto-construção envolvendo as invasões, os loteamentos clandestinos e outras formas de habitação precária, que constituem a ocupação informal na área urbana. Informal no sentido de que se constituíram à revelia dos parâmetros urbanísticos estabelecidos e cresceram fora das regras de segurança e conforto estabelecidos pelo poder público para edificações e parcelamento, portanto, sem controle público.

A invasão do Corta Braço, em 1946, hoje o bairro de Pero Vaz, foi o primeiro movimento social, em Salvador, com esta característica para a construção de habitações. Já nos anos sessenta vai acontecer a expansão do sistema viário da cidade, expressando o desenho da cidade definido nos anos 40 pelo EPUCS Escritório do Plano de Urbanismo da Cidade do Salvador, plano coordenado por Mario Leal Ferreira (PMS, 1976), que incorporou espaços novos ao tecido urbano e aumentou o valor da terra urbana, trazendo ao mercado terras que não estavam disponíveis e abrigavam muitas das habitações precárias da cidade, que ocupavam fundos de vale e encostas.

No início dos anos 90, em Salvador as, assim chamadas, invasões chegavam a 14\% das áreas ocupadas por habitação, somadas a outras áreas de ocupação informal, estas áreas chegariam a 32\% da ocupação habitacional (Souza, 2000).

As ocupações habitacionais atuais espelham as conclusões apontadas no texto As "Cidades" de Salvador, de Carvalho e Pereira, nesta publicação. As áreas com condições mais inadequadas em termos habitacionais se localizam no Subúrbio Ferroviário e Miolo, no que foi denominado "cidade precária" e as com melhores condições se localizam na área central e ao longo da Orla Atlântica, onde existem ilhas de ocupação informal em bairros populares, que se originaram quando estas terras não eram valorizadas. Estas ilhas de precariedade na "cidade moderna" são hoje classificadas como ZEIS - Zona de Especial Interesse Social, pelo plano diretor de Salvador.

A Zona de Especial Interesse Social é um instrumento urbanístico 
regulamentado no Estatuto da Cidade em 2001 que deve ser entendida como uma classificação especial no zoneamento da cidade a partir de plano específico que permitiria um padrão urbanístico próprio. Com este espírito, o Plano Diretor de Desenvolvimento Urbano (PDDU) de Salvador, aprovado em 2004, estabeleceu Áreas de Especial Interesse Social (AEIS), identificando 3 diferentes tipos. Tratam de áreas ou edificações ocupadas predominantemente com assentamentos de ocupação precária e popular, em áreas de propriedade pública, ou em áreas de propriedade privada ou áreas desocupadas destinadas à implantação de habitação de interesse social - HIS - com vistas à redução da demanda anual ou do déficit habitacional, em programas de relocação de assentamentos ou de desabrigados. A revisão do PDDU de Salvador, aprovada no final de 2007, classifica estas áreas em cinco tipos e acrescenta outras, além das áreas ocupadas com habitações precárias, como conjunto de edificações deterioradas em áreas com infra-estrutura consolidada. No caso de Salvador este instrumento permite que os órgãos de planejamento concedam um tratamento diferenciado do que é dado ao restante do espaço urbano, reforçando aqui a percepção destas áreas, particularmente das áreas ocupadas com habitações precárias, inseridas na cidade "moderna", como ilhas num território diverso.

Dentre as características das áreas ocupadas destacam-se, alem da precariedade das habitações, o grande adensamento das áreas antigas, com alguns bairros mais populosos como o Nordeste de Amaralina, que em 2000 contava com mais de 70.000 habitantes, chegando a uma densidade de mais de 45.000 habitantes por quilometro quadrado. Em termos sócio-econômicos as áreas têm em comum a pobreza de seus habitantes, embora aqui também se registra desigualdade. No bairro da Paz mais da metade da população tem renda per capita familiar até meio salário mínimo, ao passo que no já citado Nordeste de Amaralina, este índice é inferior a 30 por cento, próximo a média das demais Zonas (estimativa a partir de processamento de dados do censo IBGE, 2000).

$O$ benefício que a institucionalização das ZEIS pode trazer para a população daquelas áreas é a implementação de parâmetros urbanísticos que protegem estas áreas da pressão dos interesses dos grandes agentes empreendedores imobiliários e comerciais. Estes agentes podem tentar influenciar o Legislativo e Executivo municipal para flexibilizar as normas de áreas próximas a bairros ou locais de maior valorização fundiária e próximos a setores da cidade onde habitam parcelas da população com maior renda e que ocupam lugares mais alto na hierarquia social, como os expressos nos tipos sócioespaciais superior e médio-superior, tipologia sócioespacial proposta por Carvalho e Pereira no texto As "Cidades" de Salvador, já mencionado. O outro lado da mesma moeda é o reforço da segregação. Ainda que não seja esta a intenção deste instrumento urbanístico é uma conseqüência inevitável do tratamento diferenciado do espaço.

O mapa 1 mostra a distribuição das áreas ocupadas (definidas no PDDU aprovado em 2004 como AEIS 1 e AEIS 2), e alguns indicadores sobre população, renda e instrução que permitem a caracterização das mesmas. 
Mapa 1 - AEIS definidas pelo PDDU 2004 - Salvador
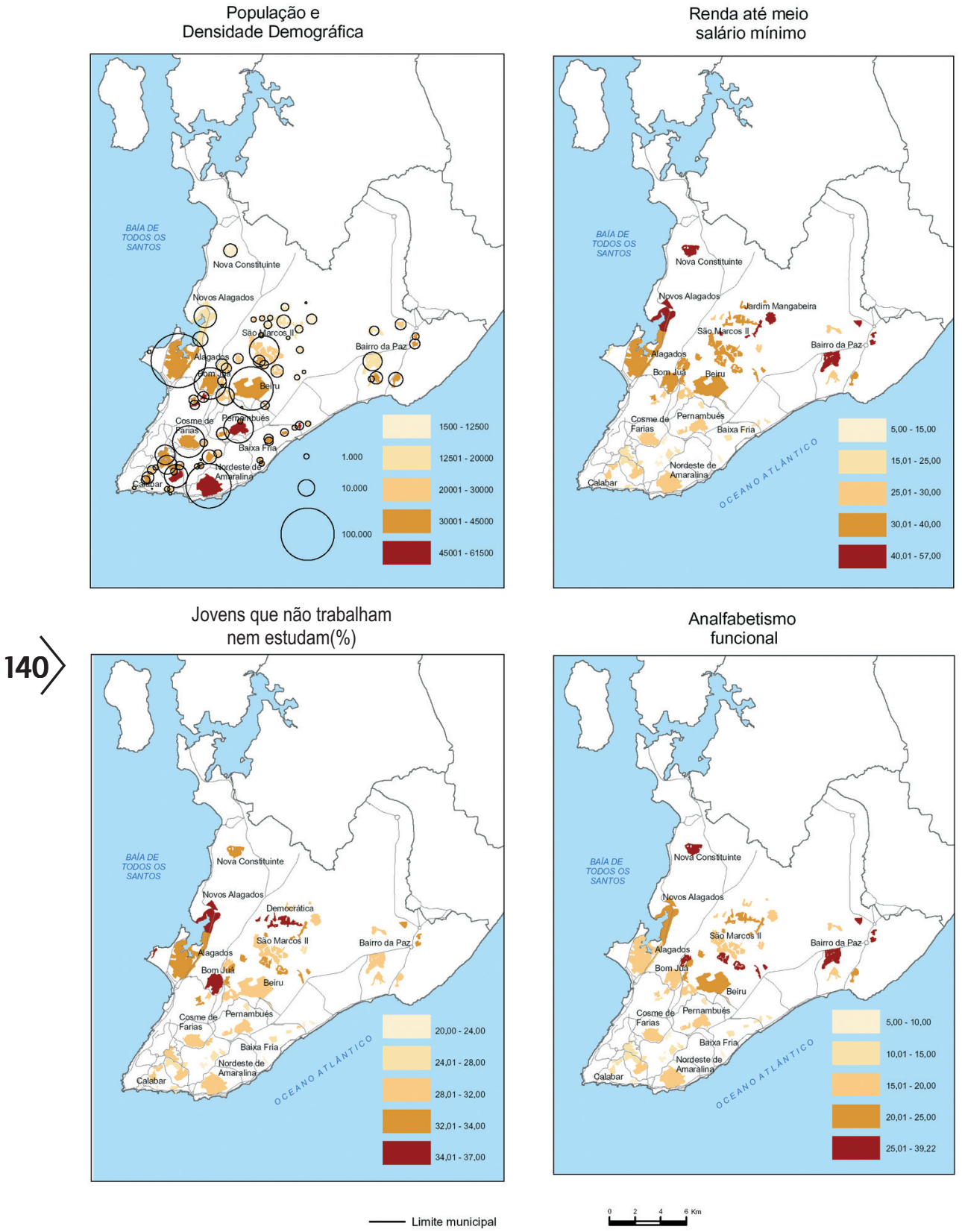

Fonte: IBGE. Censo Demográfico 2000. Mapa elaborado pelo autor. 
Em termos de pobreza se destacam o Bairro da Paz, área de extrema pobreza e precariedade, mais próxima à orla atlântica e Novos Alagados e Nova Constituinte, na cidade precária. Outro indicador, o percentual de jovens sem trabalho nem estudo, destaca Novos Alagados e aparecendo ainda o bairro de Bom Juá. Quando se analisa o percentual de analfabetismo funcional voltam a aparecer em destaque o Bairro da Paz e Nova Constituinte. Numa tentativa de síntese pode-se dizer que as áreas mais antigas e consolidadas, localizadas próximas ao Centro Tradicional ou à Orla, como Cosme de Farias, Pernambués, Engenho Velho da Federação tem uma densidade demográfica extremamente alta, se destacando neste aspecto o Nordeste de Amaralina, estando estas áreas num claro processo de verticalização, e as áreas mais distantes da cidade moderna, portanto da localização de serviços, empregos e equipamentos tem densidade demográfica menor e abrigam população com renda mais baixa, maior índice de desemprego e menor instrução, ou seja, a população mais vulnerável.

Em 2000 estima-se que o conjunto destas áreas abrigava cerca de 650.000 habitantes, sendo que algumas delas têm uma população equivalente a uma cidade de porte médio numa área extremamente compacta. Como comparação podemos registrar que a terceira cidade do estado em população, Vitória da Conquista, tinha em 2000 pouco mais de 260.000 habitantes e Alagados superava os 100.000 habitantes.

Salvador entra no século XXI com uma população de quase 2,5 milhões de habitantes. $O$ crescimento da população e a pobreza de seus habitantes trazem limitações à expansão da ocupação de seu território. Estudo realizado tendo como fonte levantamento aerofotográfico de 2002, pelo LCAD/UFBA, ${ }^{1}$ para a Secretaria de Habitação apontou para a existência de poucas áreas livres possíveis para ocupação habitacional. Neste estudo constatou-se que áreas desocupadas que poderiam receber ocupação residencial seriam pouco mais de $14 \%$ do território continental de Salvador. Se forem consideradas somente as áreas classificadas como adequadas a receber projetos de habitação de interesse social esse percentual vai ficar pouco acima de 10\% do território (PMS/SEHAB, 2007).

Esse quadro de escassez de terras livres se agrava porque a ele se somam as demandas do capital imobiliário, voltadas para 0 atendimento do mercado formal residencial dos setores médios e altos da população, com a oferta de condomínios horizontais e verticais e grandes centros de consumo e serviços e a existência de reservas ambientais, parques e mananciais. Esta escassez tem contribuído para um processo crescente de verticalização das áreas de habitação popular mais antigas, que passam a atingir mais de três pavimentos e em alguns casos chegam a seis ou sete pavimentos, contribuindo para o agravamento das condições de habitabilidade nessas áreas, com uma alta densidade demográfica. Nas áreas menos consolidadas e de ocupação recente, o padrão é a ocupação horizontal por

\footnotetext{
${ }^{1}$ Núcleo de pesquisa da Faculdade de Arquitetura da Universidade Federal da Bahia.
} 
habitações precárias e autoconstruídas, freqüentemente em áreas de risco, como encostas de alta declividade ou áreas sujeitas a alagamentos e em reservas ambientais. Recentemente observa-se um processo de ocupação de prédios vazios e ociosos na área central da cidade por famílias de sem-teto, sobretudo na área do Comércio.

A expansão urbana de Salvador, segue dois vetores distintos: a OrlaAtlântica Norte, espaço "nobre" em termos de moradia, infra-estrutura e serviços urbanos, que se conecta ao município de Lauro de Freitas e tende a seguir ao longo da chamada "Estrada de Coco", via litorânea que segue paralela ao litoral norte; 0 Miolo, área geograficamente central da cidade, que se localiza entre a Avenida Paralela e a BR-324 e o Subúrbio Ferroviário, área que se desenvolve a partir dos anos $40 \mathrm{com}$ a localização de loteamentos populares e hoje é marcada por habitações precárias e pela deficiência de equipamentos, serviços e infra-estrutura. A Orla Atlântica é a área de expansão dos setores sociais superiores, em Salvador, Lauro de Freitas e parte mais próxima da orla de Camaçari, com um padrão residencial alto, já o Miolo e o Subúrbio podem ser caracterizados como a área de expansão da população pobre com habitações precárias. Este vetor se expande, a partir do município de Salvador na direção do município de Simões Filhos e no interior de Lauro de Freitas, onde persiste a oposição com a orla, como o lugar das categorias "superiores" (ver capítulo precedente). Os maiores índices de crescimento populacional se situam nos municípios vizinhos à Salvador, ou seja Lauro de Freitas, Simões Filho e Camaçari.

Nos demais municípios da RMS, as evidências do ambiente construído nas suas sedes demonstram claramente a predominância de áreas informais, com alto grau de deficiências urbanísticas, seguindo o mesmo padrão de precariedade física e de periferização no contorno dos núcleos centrais, semelhantes ao que ocorre em Salvador, ainda que abrangendo uma menor população e, no caso de Camaçari, com uma ocupação na franja entre a via litorânea e a praia com habitações de alto padrão.

\section{PADRÕES DE MORADIA}

Para caracterização dos padrões de moradia foram tomados dois indicadores, ambos variáveis do censo de 2000: "habitação com até 3 cômodos" e "domicílio tipo apartamento".

Para a identificação das áreas de ocupação informal existentes em 2000 utilizou-se como indicador a variável do último Censo sobre "habitação com até 3 cômodos", que indica sua provável precariedade, pois caracteriza a convivência na moradia de usos conflitantes - cozinha, banheiro, dormitório e estar -, que usualmente são exercidas em locais exclusivos no domicilio e dizem respeito às funções de preparo de alimentos, higiene pessoal, repouso e estar. Em Salvador 
esses domicílios constituíam 14,7\%, embora em termos absolutos seu número fosse elevado: 95.537, de um total de 651.000 domicílios existentes em 2000 na capital. Nos demais municípios da Região Metropolitana esse percentual era mais significativo, chegando a 20,7\% em Dias D'Ávila, 23\% em Simões Filho e 25,3\% em Camaçari.

Mapa 2 - Domicílios com até 3 cômodos (percentual) - Região Metropolitana de Salvador - 2000

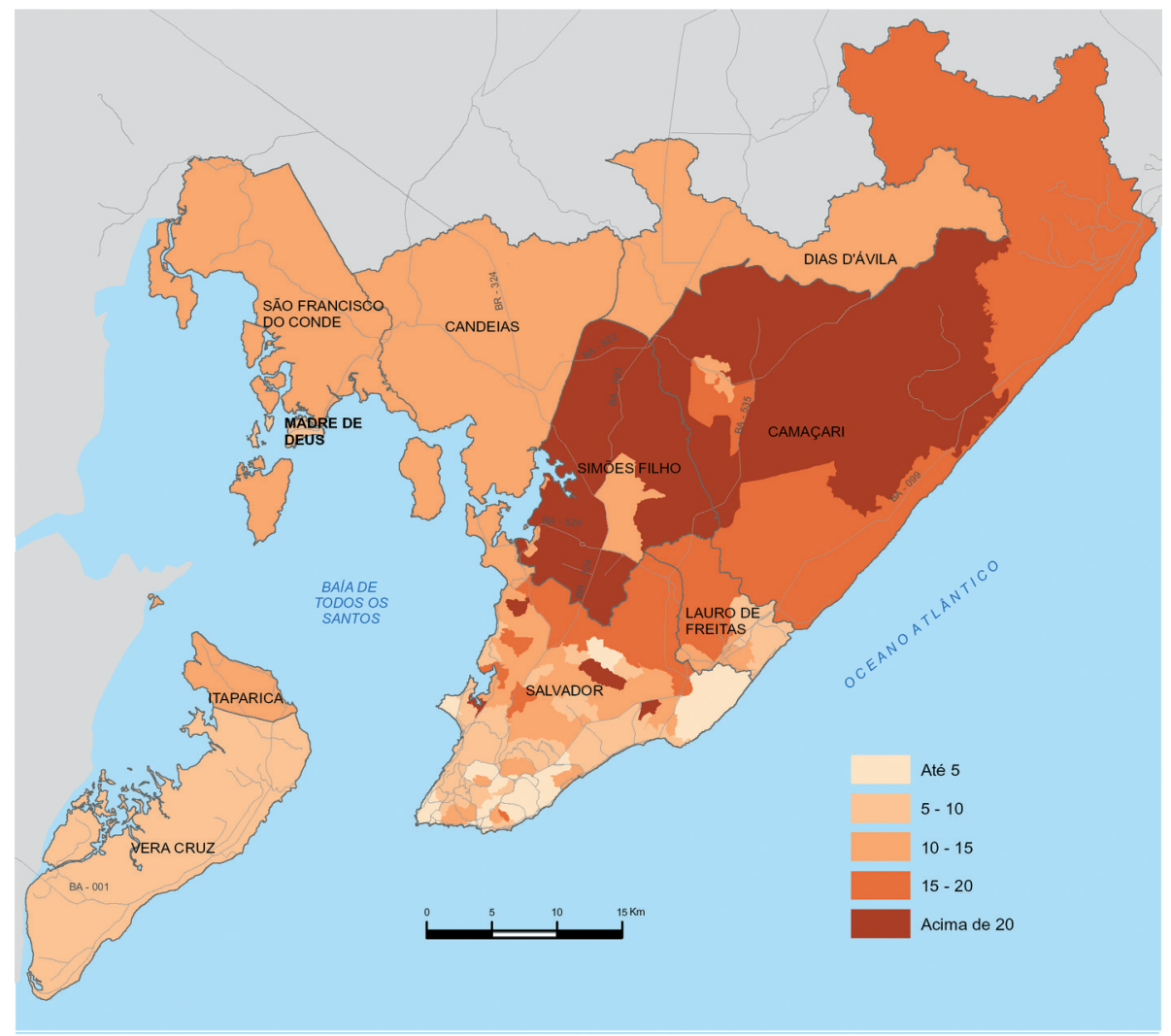

Fonte: IBGE. Censo Demográfico 2000. Mapa elaborado pelo autor

A distribuição espacial de domicílios com até 3 cômodos apresentada no Mapa 2 ilustra a concentração de habitações mais precárias e em condições de informalidade; notadamente no centro geográfico do município e na Orla da Baía de Todos os Santos (áreas que correspondem aos Subúrbios Ferroviários e ao Miolo) e nos demais municípios da RMS, com a exceção de Vera Cruz, onde existe um grande número de domicílios voltados ao uso de lazer por residentes de Salvador, as chamadas casas de veraneio.

O segundo indicador diz respeito aos domicílios tipo apartamento, que são habitações pluridomiciliares, verticais e normalmente de maior qualidade 
construtiva, cujo acesso se dá, quase sempre, através do mercado imobiliário formal. Este tipo de domicilio predomina nas áreas do Centro Tradicional e em parte da Orla Atlântica de Salvador, da Barra até Pituba/Costa Azul. A partir daí as habitações pluridomicilares convivem com habitações unidomiciliares - casas -, ficando fora deste padrão na Orla somente a área de Itapuã, ao norte do município de Salvador, e Lauro de Freitas, onde predominam habitações horizontais - residências e condomínios, mas de bom padrão construtivo. Nessas áreas não predominam domicílios "tipo apartamento", nem tampouco domicílios com até 3 cômodos.

Além dessas áreas indicadas existem domicílios tipo apartamento no Miolo, como se vê no mapa 3 que correspondem à conjuntos habitacionais destinados à população de baixa renda e financiados pelo Estado ao tempo do então BNH. Data dos anos sessenta e setenta a periferização dos conjuntos que expressavam então uma forma de segregação sócioespacial (Sampaio, 1999, p.114). No entorno destas manchas de ocupação por domicílios tipo apartamento existem habitações de até três cômodos, como se percebe pela comparação entre os dois

\section{Mapa 3 - Domicílios tipo apartamento - Região Metropolitana de Salvador 2000}

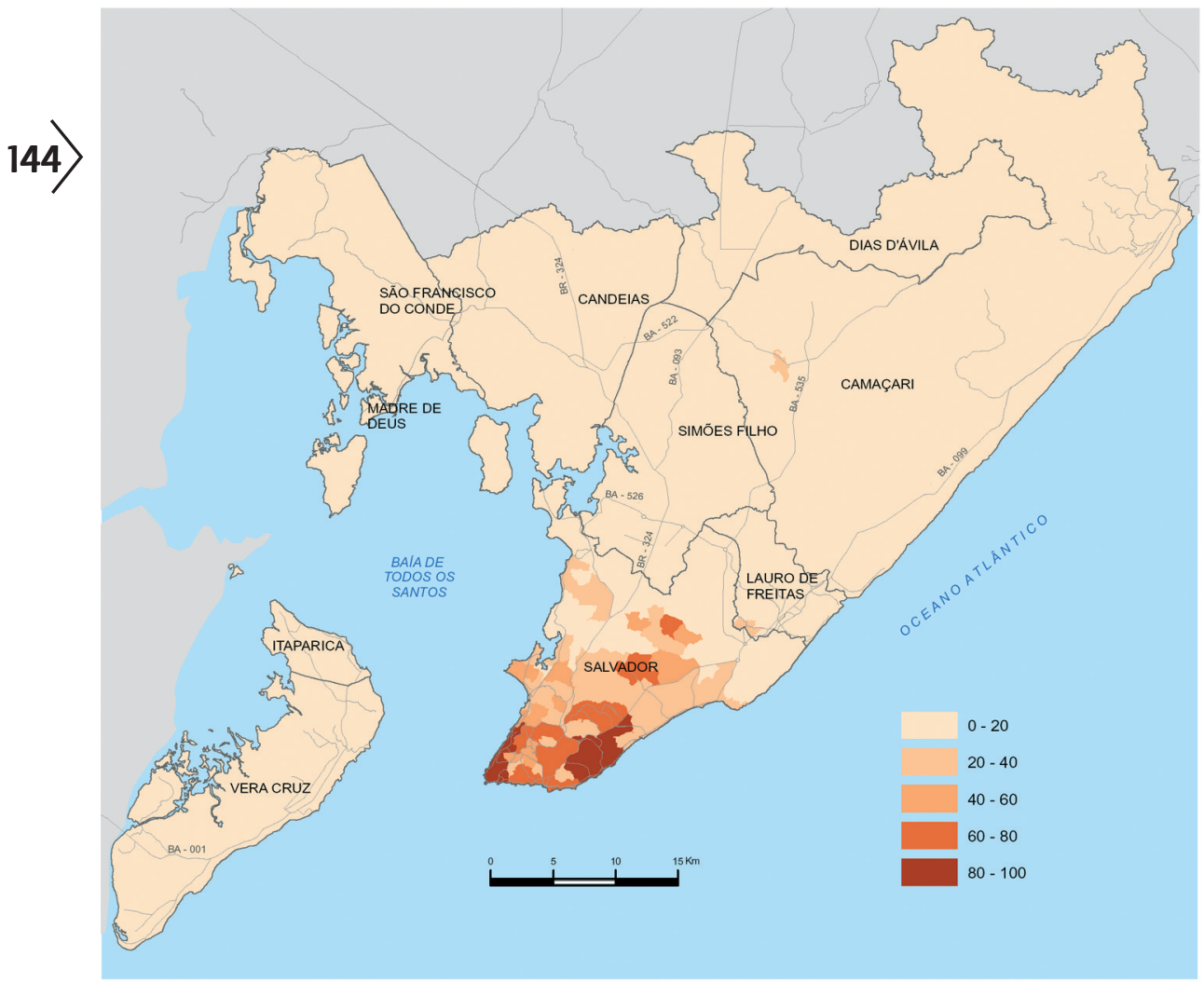


mapas. Notável também é a ausência quase total deste padrão de habitação nos demais municípios da RMS. A leitura desses dois mapas reforça a percepção de uma cidade desigual também em termos do acesso à moradia.

Outro indicador da precariedade das condições de moradia em Salvador são os dados sobre propriedade domiciliar. Em uma região caracterizada pela pobreza de sua população, paradoxalmente, grande parte dos habitantes são proprietários de seus domicílios - precários, ou não - podendo-se inferir que a impossibilidade de acesso da maior parte da população ao mercado imobiliário formal e a soluções como aluguel de habitações a leva a produzir sua própria moradia. A Tabela 1 traz dados sobre a propriedade (do domicilio e do terreno) mostrando que do total de domicílios existentes em Salvador 530.239 são próprios; em 483.980 os proprietários tem também são donos do terreno. Isto quer dizer que mais de oitenta por cento dos domicílios de Salvador são próprios e destes só dez por cento não são também proprietários dos terrenos, o que se explica pela produção de moradias através de invasões e auto-construção, processos motivados em grande parte pela incapacidade da população adquirir suas moradias e também pela carência de políticas públicas direcionadas a esta questão.

Tabela 1 - Municípios da Região Metropolitana de Salvador por domicílios particulares permanentes próprios, alugados e outros - 2000

\begin{tabular}{|c|c|c|c|c|c|c|}
\hline \multirow{3}{*}{ Município } & \multirow{3}{*}{ Total } & \multicolumn{5}{|c|}{ Domicílios particulares permanentes } \\
\hline & & \multicolumn{3}{|c|}{ Próprios } & \multirow[b]{2}{*}{ Alugados } & \multirow[b]{2}{*}{ Outros } \\
\hline & & Total & $\begin{array}{c}\text { Com propriedade } \\
\text { do terreno }\end{array}$ & $\begin{array}{l}\text { Sem propriedade } \\
\text { do terreno }\end{array}$ & & \\
\hline Camaçari & 41.238 & 32.348 & 28.553 & 3.796 & 4.797 & 4.093 \\
\hline Candeias & 18.779 & 15.724 & 12.710 & 3.014 & 1.887 & 1.168 \\
\hline Dias d'Ávila & 11.286 & 9.636 & 9.184 & 452 & 870 & 781 \\
\hline Itaparica & 4.848 & 3.933 & 3.399 & 535 & 280 & 635 \\
\hline Lauro de Freitas & 29.160 & 24.077 & 22.793 & 1.285 & 3.153 & 1.929 \\
\hline Madre de Deus & 2.925 & 2.458 & 2.301 & 157 & 343 & 124 \\
\hline Salvador & 651.008 & 530.239 & 483.980 & 46.260 & 92.018 & 28.751 \\
\hline São Francisco do Conde & 6.185 & 5.374 & 4.790 & 584 & 301 & 510 \\
\hline Simões Filho & 23.121 & 19.179 & 17.682 & 1.497 & 2.010 & 1.932 \\
\hline Vera Cruz & 7.650 & 6.252 & 5.774 & 478 & 654 & 745 \\
\hline Total & 796.200 & 649.221 & 591.164 & 58.057 & 106.312 & 40.667 \\
\hline
\end{tabular}

Quanto ao déficit habitacional básico, constituído pela soma da coabitação familiar, dos domicílios improvisados e dos rústicos - a terminologia e a fonte dos dados usados é a Fundação João Pinheiro, constata-se que, proporcionalmente, as melhores situações são as de Salvador e Lauro de Freitas, com déficits de $12 \%$. Em Camaçari e Dias D'Ávila, os déficits chegam a 17\%; em Candeias, a 18\%, e nos demais municípios, que aparecem agregados, ele ultrapassa 19\%. Já em números absolutos, 0 déficit habitacional em Salvador chega a mais de 81.000 domicílios, do número total de 
104.878 relativo à Região Metropolitana. Note-se ainda que Salvador se destaca também por praticamente não ter domicílios rurais, como se vê na Tabela 2.

Tabela 2 - Déficit habitacional básico - Regiấo Metropolitana de Salvador - 2000

\begin{tabular}{l|r|r|r|r|r|r|r|r|r}
\hline \multirow{2}{*}{ Município } & \multicolumn{3}{|c|}{ Absoluto } & \multicolumn{3}{c|}{ Percentual } & \multicolumn{3}{c}{ Domicílios Vagos } \\
\cline { 2 - 11 } & \multicolumn{1}{|c|}{ Total } & Urbana & \multicolumn{1}{c}{ Rural } & Total & Urbana & Rural & \multicolumn{1}{c}{ Total } & Urbana & Rural \\
\hline Camaçari & 7.127 & 6.775 & 352 & 17,28 & 17,18 & 18,57 & 7.512 & 7.030 & 482 \\
\hline Candeias & 3.382 & 2.920 & 462 & 18,01 & 17,23 & 25,26 & 2.733 & 2.444 & 289 \\
\hline Dias D'Ávila & 1.990 & 1.803 & 187 & 17,63 & 17,01 & 27,10 & 1.926 & 1.797 & 129 \\
\hline Lauro de Freitas & 3.567 & 3.361 & 206 & 12,23 & 12,07 & 15,79 & 4.794 & 4.582 & 212 \\
\hline Salvador & 81.429 & 81.390 & 39 & 12,51 & 12,51 & 17,26 & 89.405 & 89.337 & 68 \\
\hline Simóes Filho & 3.180 & 2.530 & 650 & 13,75 & 13,31 & 15,80 & 2.947 & 2.218 & 729 \\
\hline Demais municípios & 4.113 & 3.805 & 308 & 19,03 & 19,04 & 18,86 & 4.978 & 4.632 & 346 \\
\hline Total & 104.878 & 102.626 & 2.252 & 13,17 & 13,08 & 19,42 & 114.295 & 112.040 & 2.255 \\
\hline
\end{tabular}

Fonte: Fundação João Pinheiro

É digno de nota que o número de domicílios vagos, por sua vez, é um pouco superior ao déficit habitacional estimado nos casos de Salvador, Camaçari e Lauro de Freitas e nos números totais da RMS, com 112 mil domicílios vagos para quase 105 mil domicilios que comporiam o déficit habitacional básico.

0 mapa 4 representa uma tentativa de síntese das condições habitacionais, usando outro indicador, também variável do Censo, a relação entre número de banheiros e número de domicílios, para indicar a localização de habitações de padrão mais alto (domicílios com mais de 3 banheiros) e mais baixo (número de banheiros menor que o número de domicílios). Estes dados, mais os indicadores anteriores, apresentados nos mapas 2 e 3 - domicilio tipo apartamento e domicílios com até 3 cômodos - permitiram uma leitura baseada nos dados censitários expressos nas AEDS, que cruzados com o mapa da mancha edificada feita a partir da interpretação de fotos aéreas verticais de 2002 nos indicou uma possivel tipologia habitacional distinguindo a localização das habitações de padrão alto, médias, inadequadas e precárias.

As áreas da Orla, a "cidade moderna", são ocupadas por habitações cujo acesso se dá pelo mercado formal, que obedecem às disposições urbanísticas municipais no que diz respeito à edificação e uso do solo. Ali se distribuem as habitações de padrão mais alto. Na Orla mais ao Norte habitações de alto padrão unidomiciliares - casas de luxo - localizadas principalmente em condomínios horizontais e loteamentos fechados. Nas áreas mais centrais, como Barra, Graça, Pituba as habitações de alto padrão se encontram principalmente em condomínios verticais, com um processo em curso de substituição dos imóveis com menor área construída por edifícios cada vez mais altos.

$\mathrm{Na}$ "cidade tradicional" temos domicílios adequados de padrão médio, em habitações antigas e numa mancha ocupada compacta e contínua. Aqui cabe registrar que embora o processo de esvaziamento do centro tradicional persista, já 
Mapa 4 - Tipologia habitacional - Salvador - 2000

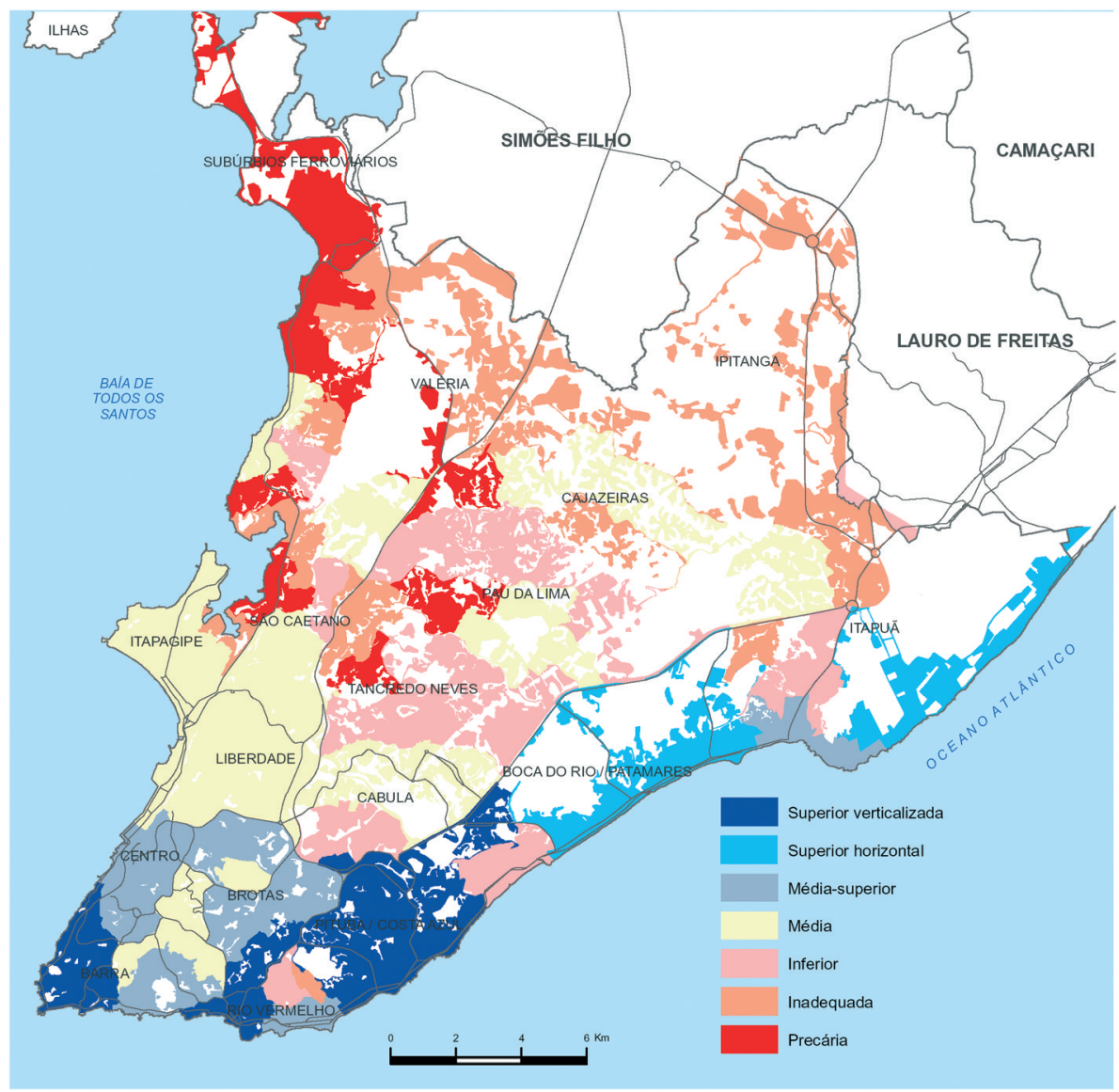

Fonte: IBGE. Censo Demográfico 2000. Mapa elaborado pelo autor, a partir do Censo e de interpretação de fotos aéreas verticais de 2002.

se pode notar que está em curso um fenômeno de gentrificação, ou seja, um processo de transformação do espaço urbano, com a substituição dos moradores antigos por novos, de maior poder aquisitivo, simultaneamente a uma valorização imobiliária do espaço urbano. $O$ fenômeno, ainda é muito recente para ser registrado por dados censitários, mas pode ser visto na imprensa que repercute as transações imobiliárias que são ligadas ao processo. ${ }^{2}$

$\mathrm{Na}$ "cidade precária" predomina a informalidade, em termos de padrões urbanísticos e de mercado, assim como a precariedade em termos habitacionais, particularmente no Subúrbio Ferroviário. No Miolo coexistem habitações formais (conjuntos habitacionais de baixo padrão), loteamentos populares e moradias

${ }^{2}$ O jornal A Tarde de 27/04/2008, por exemplo registra o investimento de 8 milhões na aquisição de 45 imóveis (a maior parte degradados ou em ruínas) na região do Centro Tradicional. 
precárias auto-construídas. A mancha de ocupação é dispersa e descontínua. Nos trechos da Orla as áreas precárias aparecem como ilhas, sendo caracterizadas como Zonas Especiais em termos de legislação urbanística, conforme registrado anteriormente.

Os domicílios apontados como inadequados, no mapa 4 são os que estão em áreas onde a relação banheiro/domicilio é menor do que 1, ou seja, parte das habitações não tem banheiro, já os registrados como precários são os que somam a esta condição um alto percentual de domicílios com até 3 cômodos. As habitações superiores são as que estão em áreas onde existe um alto percentual de domicílios com mais de 3 banheiros. A coincidência desta situação com a predominância da variável domicílios tipo apartamento indica as áreas de habitação superior verticalizadas. 0 resultado final desta síntese é o mapa 4 - tipologia habitacional. A tipologia proposta pode ser considerada como a expressão física dos processos de segregação sócioespacial registrados na cidade.

\section{INFRA-ESTRUTURA E SERVIÇOS URBANOS}

Em termos de infra-estrutura e acesso aos serviços básicos, o avanço que vem se registrando em Salvador não pode ser menosprezado, particularmente 0 acesso à água e esgoto, bastante abrangente agora. Conforme os dados do Censo de 2000, quase toda a área de Salvador encontrava-se coberta por abastecimento de água por rede geral com canalização em pelo menos um cômodo, situação considerada como adequada. Nos demais municípios da região metropolitana esse abastecimento é mais precário, com as exceções de Dias D'Ávila e Vera Cruz, que apresentam condições um pouco melhores, da orla de Lauro de Freitas, parte da orla de Camaçari e sua sede.

O escoamento sanitário adequado, ou seja, domicílios com esgotamento ligado à rede geral ou à fossa séptica, a situação é similar. Salvador apresenta a melhor posição, ainda que a área do município coberta por escoamento sanitário adequado seja bem menor que a área atendida por abastecimento de água, o município tem boa parte de seu território coberto. O programa Bahia Azul e o grande investimento realizado pelo estado em Salvador explicam esta situação Quanto aos demais municípios, observa-se que a orla de Camaçari não possui escoamento sanitário adequado, fato que poderá vir a causar prejuízos ambientais e de saúde pública, na medida em que a área venha a sofrer adensamento, tendência que se configura hoje.

De todo modo a implantação de rede de esgotamento sanitário não garante o esgotamento sanitário, visto que a solicitação de serviço deve ser feita (e paga) pelo morador e, no caso das populações de baixa renda, freqüentemente a opção é canalizar o esgoto para fossas ou a rede de drenagem pluvial existente.

Os mapas 5 e 6 mostram a situação em Salvador quanto ao acesso domiciliar à infra-estrutura urbana. Observa-se que a coleta de lixo e o abastecimento 
Mapa 5 - Infra-estrutura Urbana (percentual) - Salvador - 2000

Saneamento

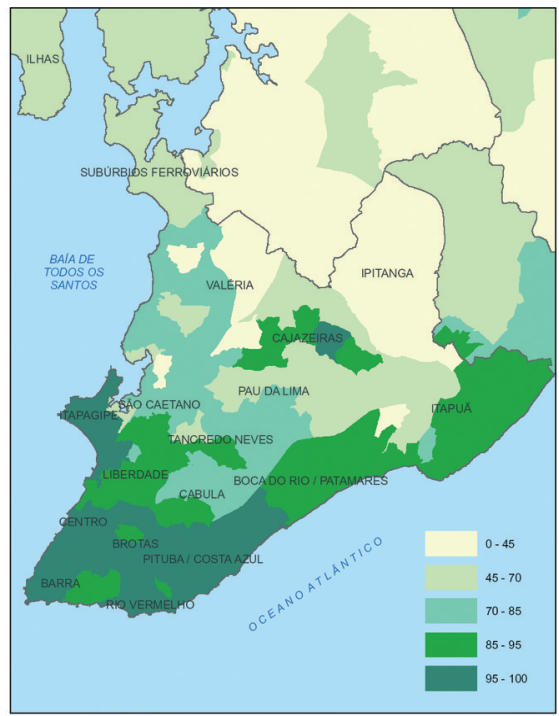

Abastecimento de água adequado

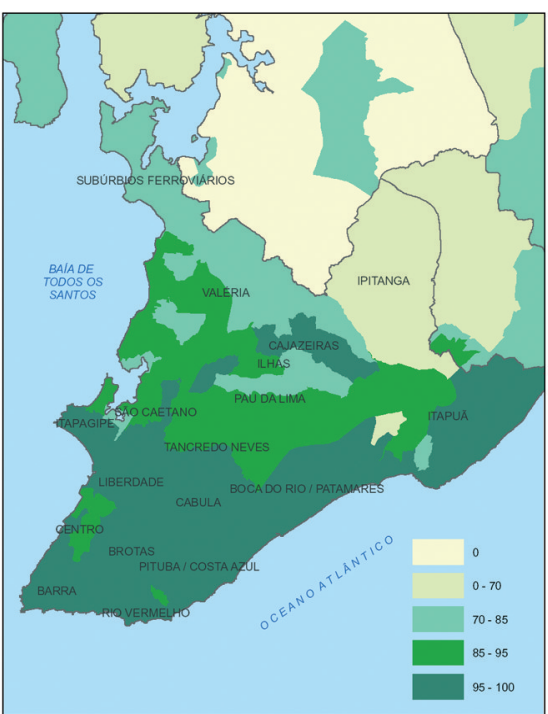

— Limite municipal
Lixo adequado

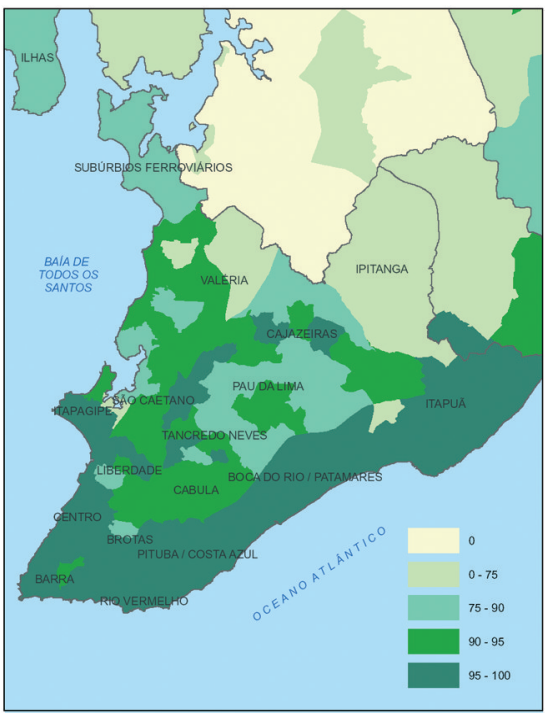

Acesso à telefone por domicílio
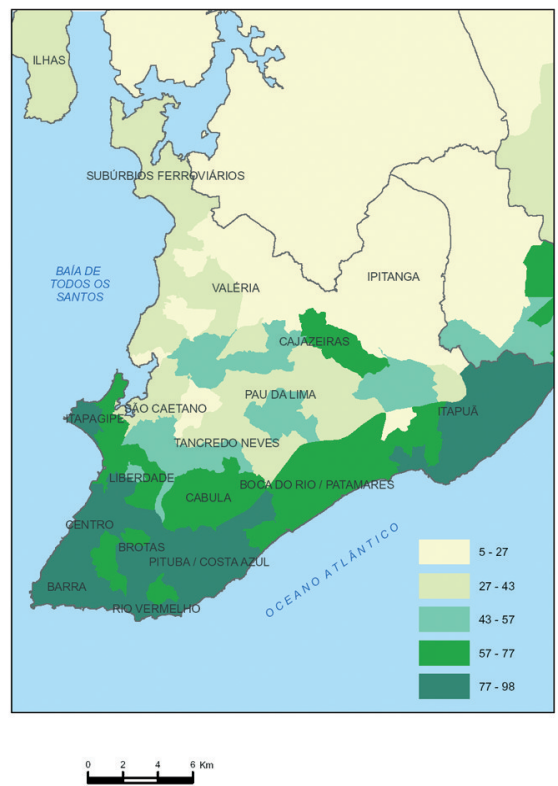

Fonte: IBGE. Censo Demográfico 2000. Mapa elaborado pelo autor. 


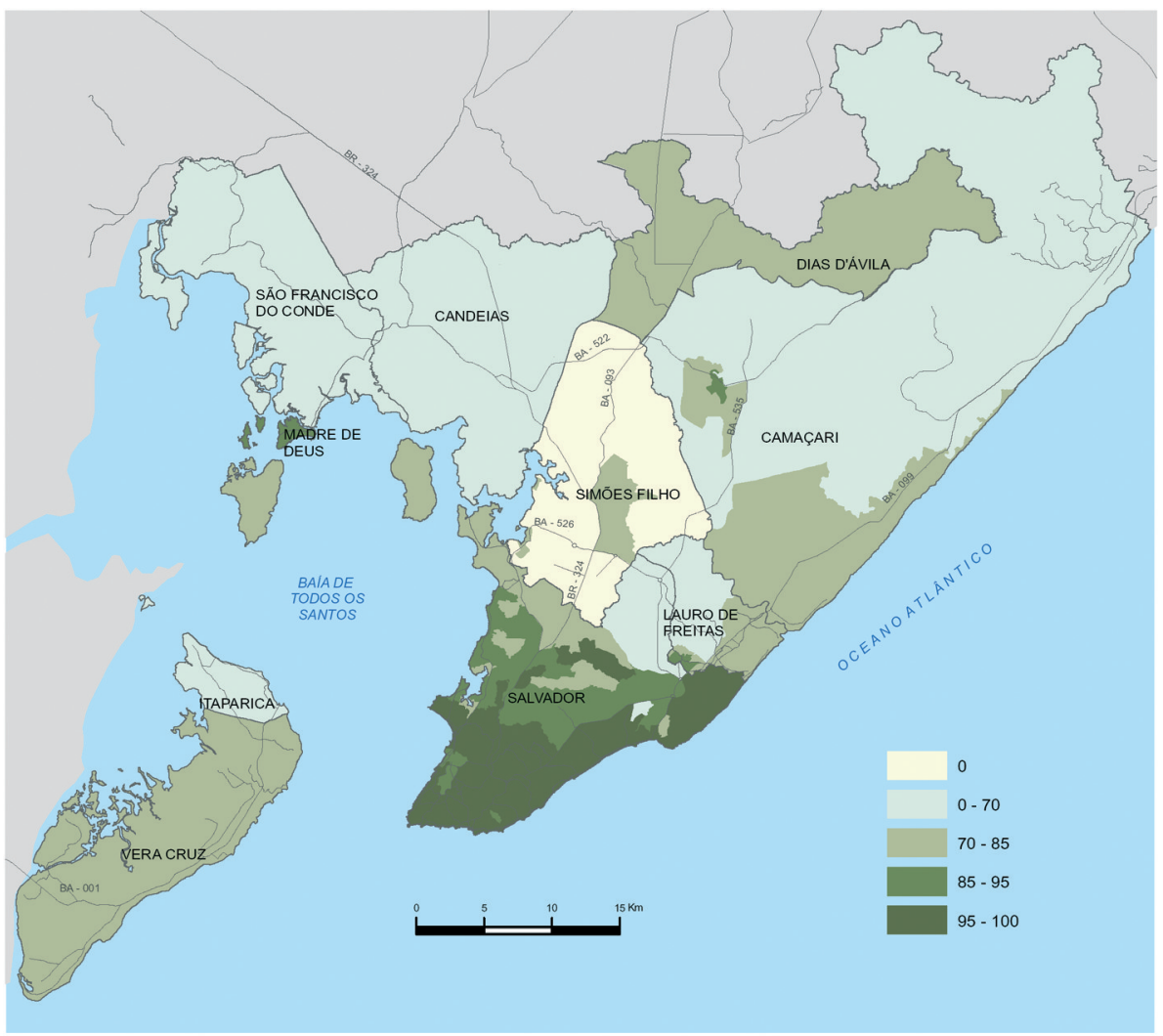

Fonte: IBGE. Censo Demográfico 2000. Mapa elaborado pelo autor.

de água alcançam praticamente toda a área do município, sendo que o acesso a rede de água que é quase universal em Salvador, não se repete nos demais municípios da RMS. A coleta de lixo adequada, por serviço de limpeza ou caçamba, ocorre em índices próximos a 100\% nos domicilios localizados na orla de Salvador e no centro tradicional do município, caindo um pouco para índices entre 90 e $95 \%$ em suas demais áreas e na orla de Lauro de Freitas. Há também alguns bolsões na faixa de 70 a 95\% no município de Salvador, que correspondem a áreas de ocupação informal no Miolo e nos Subúrbios Ferroviários na orla da Baía de Todos os Santos. Nos demais municípios, com a exceção da área da sede de Camaçari, a situação se apresenta pior que em Salvador.

Embora os índices de coleta de lixo indiquem que a coleta obedece a padrões adequados, a maioria das ocupações informais se estabelece em encostas ou fundos de vale, com padrões urbanísticos (largura de vias, declividades, etc) que nem sempre permitem o acesso de veículos de coleta de lixo, ficando, nestes casos, a cargo do morador a retirada para caixas coletoras, situação que provoca acúmulos 
de detritos e tem como conseqüências: riscos a saúde da população; possibilidade de propagação de doenças como dengue e, nos períodos de chuva, deslizamento de terras.

O acesso dos domicílios a telefone fixo já é bastante restrito nas áreas do Miolo e particularmente, nas áreas do Subúrbio Ferroviário, pois se a linha é hoje relativamente acessível, as tarifas cobradas dificultam o acesso da população de baixa renda, predominante nestes locais. 0 acesso dos domicilios a linha de telefone reflete a distribuição espacial de renda domiciliar com um acesso alto nas áreas da orla e do centro tradicional, sendo cada vez mais escasso ao norte de Salvador no Subúrbio e no Miolo, com a exceção do trecho de Cajazeiras onde predominam conjuntos habitacionais (ver o mapa 3 domicílios tipo apartamento).

\section{ACESSO A BENS}

Os domicílios da RMS revelam desigualdade também no que diz respeito ao acesso a bens, desigualdade já registrada por indicadores de moradia e acesso à infra-estrutura. Considerando os bens de uso difundido, como rádio, televisão e geladeira, cuja ausência do consumo aponta para maior precariedade do morador, Salvador é o município no qual há uma maior proporção de domicílios com todos esses bens (531.024, de um total de 651.008 domicílios), seguido por Lauro de Freitas, com 22.008 domicílios com acesso aos bens de uso difundido num universo de 29.160 domicílios.

Considerando o acesso a bens de uso restrito, como computadores e ar condicionado, Salvador se destaca proporcionalmente e em números absolutos, relevando a enorme distância que separa o município pólo da RMS dos demais. Enquanto Salvador tem 300.539 domicílios com acesso a este tipo de bens, Itaparica, no extremo oposto, tem somente 940 . Em termos proporcionais, a pior situação é a de Vera Cruz, onde 1.252 domicílios possuem acesso aos bens de uso restrito, o que equivale a pouco mais de $16 \%$ do total de domicílios. Em Itaparica, a situação é proporcionalmente melhor, chegando a 19,38\%, embora se deva considerar que, provavelmente, parte destes domicílios são usados no verão por famílias residentes em Salvador como habitações de lazer.

O mapa 7 mostra a distribuição espacial da desigualdade no interior dos municípios. Salvador e Lauro de Freitas destacam-se como as áreas da RMS que têm proporcionalmente domicílios com maior acesso a bens. No pólo da Região Metropolitana sobressaem-se as áreas do Centro Tradicional e da Orla Atlântica; em Lauro de Freitas, a sua orla. Já o mapa 8 mostra como se dá a distribuição, em Salvador, do acesso pelos domicílios a alguns bens específicos como televisão, automóvel e computadores que refletem tanto a renda do domicilio como acesso à informação. $O$ acesso a computadores, embora deva-se notar que são dados de 2000, se dá basicamente nas áreas de tipologia superior, ou média-superior, como se 
Mapa 7 - Domicílios com acesso a bens de uso difundido (percentual) - Região Metropolitana de Salvador - 2000

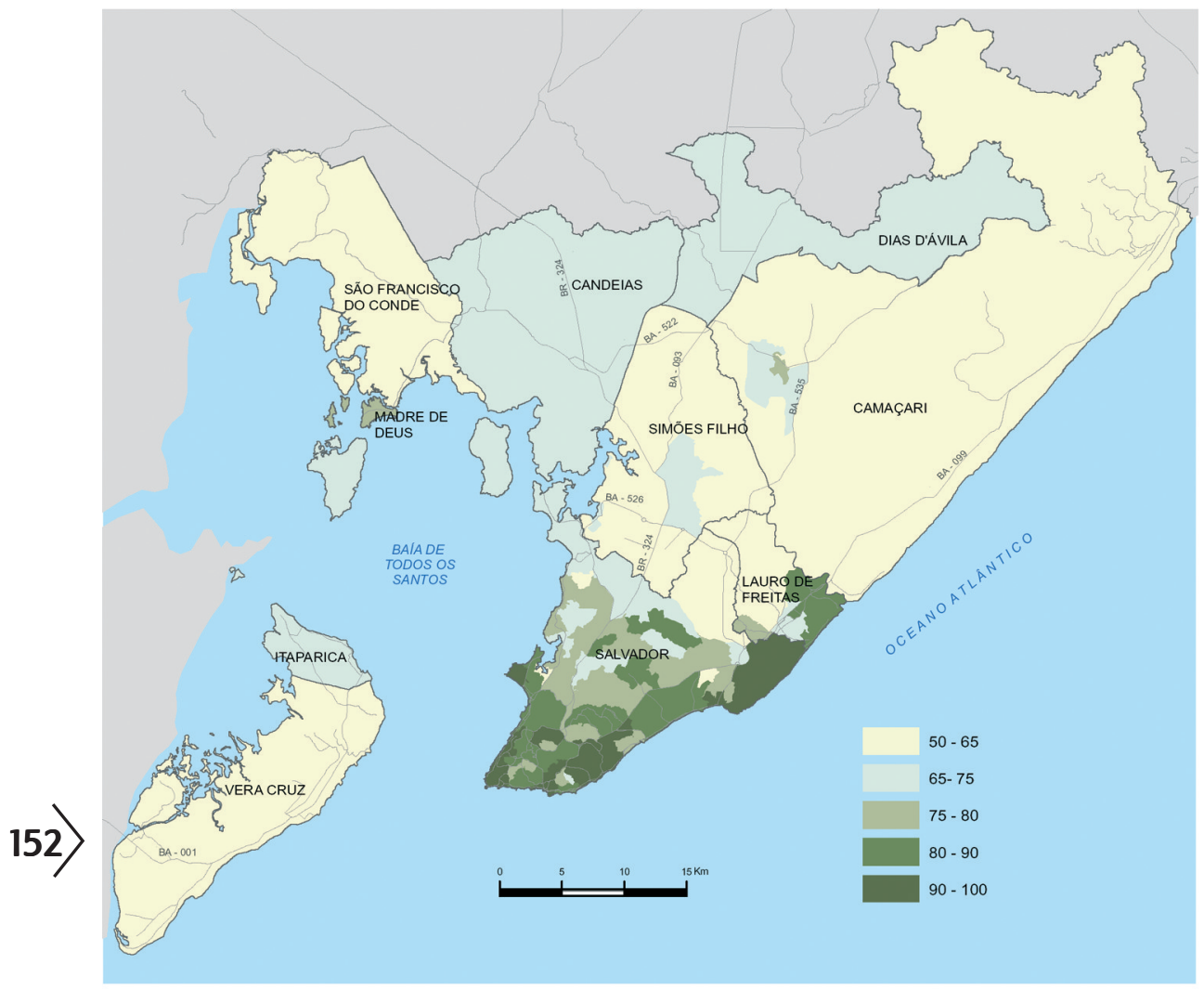

Fonte: IBGE. Censo Demográfico 2000. Mapa elaborado pelo autor.

pode ver nos mapas do capitulo anterior, áreas onde reside a população com melhor nível de instrução em habitações adquiridas no mercado formal, já o acesso a televisão é amplo tanto na orla quanto na região do Miolo, sendo mais escasso na região ao norte do subúrbio ferroviário, onde há um grande número de domicílios precários, como se viu no mapa que mostra a distribuição de domicílios com até três cômodos.

\section{CONSIDERAÇÕES FINAIS}

A diferenciação e segregação do espaço urbano e metropolitano, que se reflete nas condições de moradia, no acesso a infra-estrutura e no acesso domiciliar a bens tem se acentuado nos últimos anos e vem sendo discutida e mapeada (ver Souza, 2000; Carvalho, Souza e Pereira, 2004; Carvalho e Pereira; 2005, Pereira, 2000). Temos de um lado a proliferação de condomínios fechados de alto padrão em Salvador, entre a avenida Paralela e a orla - por exemplo, lançamento dos 
Mapa 8 - Domicílios com acesso a bens (percentual) - Salvador - 2000
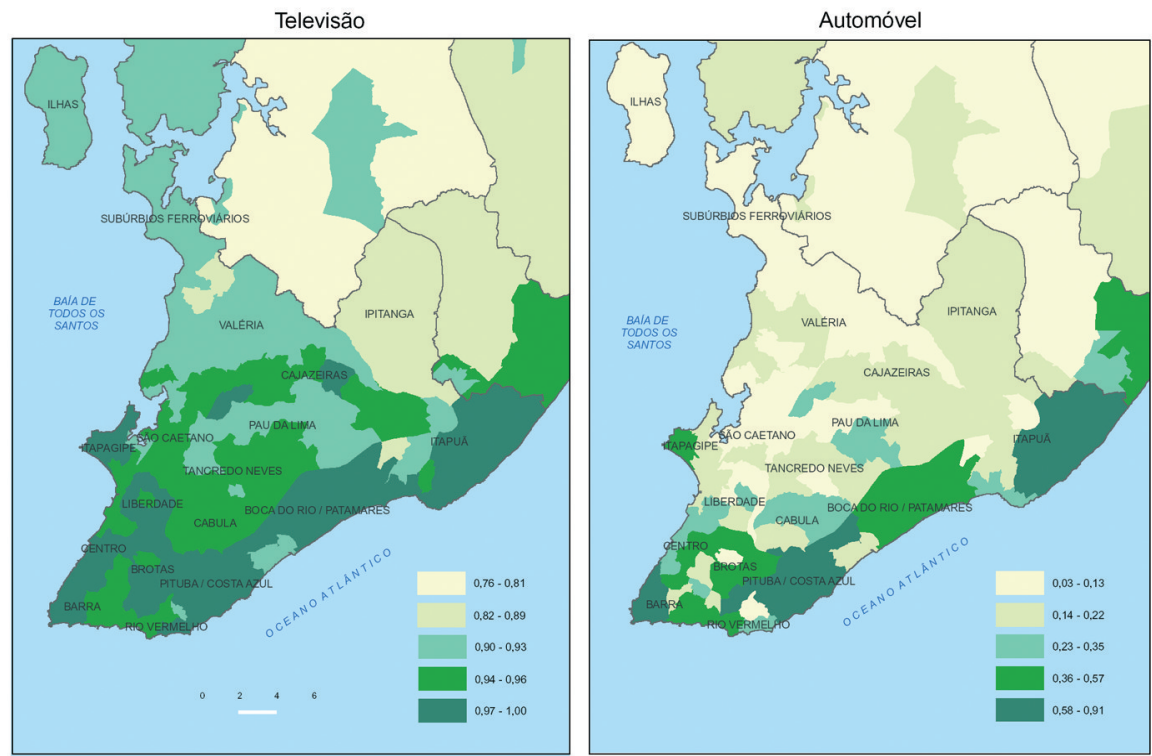

Computador
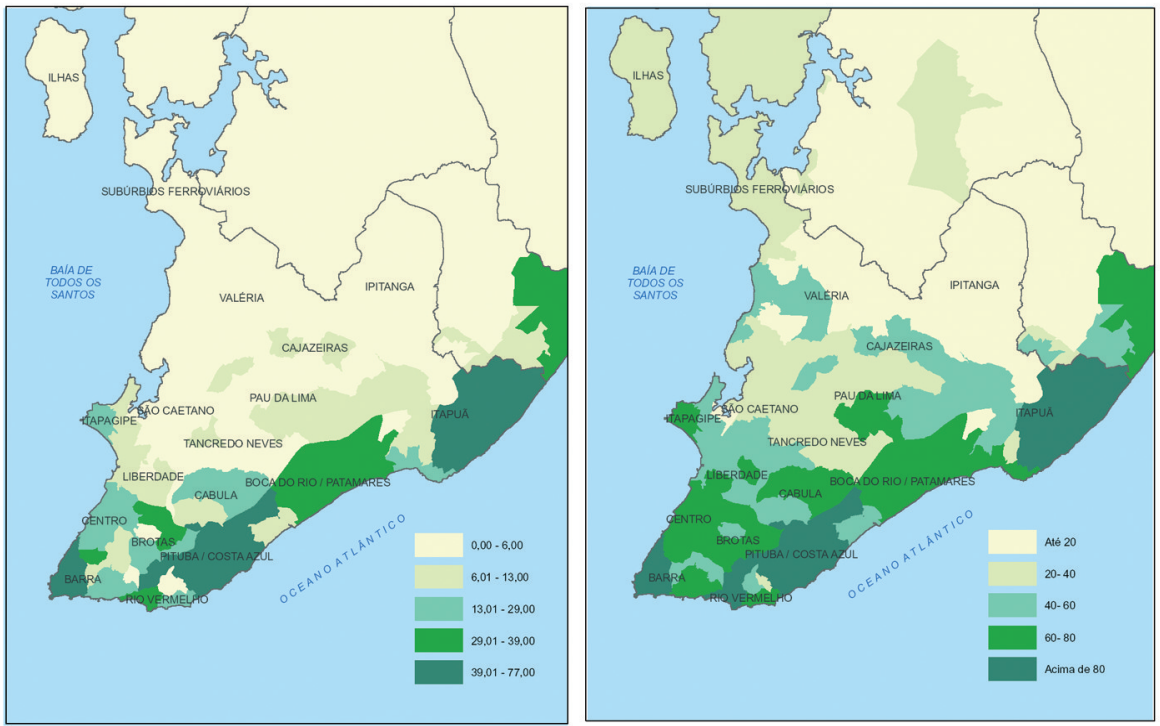

$<153$

_ Limite municipal

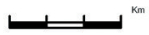

Fonte: IBGE. Censo Demográfico 2000. Mapa elaborado pelo autor.

loteamentos denominados "Alphaville" - e nas orlas de Lauro de Freitas e Camaçari de outro lado temos a ocupação horizontal do espaço urbano por habitações precárias e auto-construídas e sem controle do poder público municipal nas últimas 
áreas livres de Salvador no Subúrbio Ferroviário e no Miolo 0 esgotamento das áreas urbanas no município de Salvador, por sua vez, impulsiona a expansão da metrópole para fora dos limites municipais (ver SILVA, 1996 e CARVALHO, 2002), com a conurbação de Salvador e Lauro de Freitas e o avanço na direção Norte, ao longo da Linha Verde, com a implantação de loteamentos e condomínios de luxo e grandes equipamentos turísticos e comerciais, a exemplo do complexo turístico de Sauípe, ou da ocupação da Praia do Forte, no município de Mata de São João, que só no inicio de 2008 foi incorporado a RMS institucional.

A expansão atual da metrópole ocorre de dois modos principais. De um lado temos a intensificação do processo de verticalização de áreas da cidade moderna e de áreas consolidadas da cidade precária, nos setores da orla atlântica, da Barra/Vitória, até além da Pituba e ocupação das últimas áreas livres do território continental de Salvador. Esta tendência será incrementada pela recente (final de 2007) mudança na legislação urbanística de Salvador, com a aprovação da revisão do plano diretor de 2004, promovida pela atual administração municipal, que liberou a verticalização da orla em áreas que até então eram protegidas por gabaritos de altura restritivos. Pode-se estimar que o resultado será a extensão do processo de adensamento e verticalização, hoje em curso em áreas como a Pituba, ao longo da orla até Itapoã.

De outro lado temos a tendência de expansão horizontal com 0 espraiamento da cidade num padrão de urbanização dispersa (Reis, 2006). Na direção de Simões Filho, a expansão da cidade precária e na direção Norte na franja da orla litorânea, no padrão do que caracterizamos como cidade moderna, impulsionado neste caso pelos empreendimentos imobiliários voltados para 0 turismo e grandes condomínios horizontais fechados de habitações de alto padrão, que podem se caracterizar como segunda residência, ou moradia de fim de semana, para a elite local ou, cada vez mais, para estrangeiros. Este desenvolvimento traz grandes equipamentos de consumo e serviços e incorpora ao mercado imobiliário áreas que não eram urbanas, expulsando a população nativa para longe da franja litorânea, reproduzindo o padrão já cristalizado em Salvador e Lauro e Freitas com a orla ocupada pelas camadas sociais superiores e 0 interior ocupado pelas camadas inferiores.

Este ocupação linear que pode hoje ser caracterizada como uma área urbana sem centralidade, é uma tendência que se inicia nos anos $70 \mathrm{com}$ a implantação de loteamentos voltados para o veraneio, ganha impulso no final dos 70 e inicio dos anos $80 \mathrm{com}$ a abertura da via litorânea conhecida como Estrada do Côco, é incrementada já na década de 90 com a construção da Linha Verde - BA099 e se transforma nos anos 2000 com os investimentos turísticos imobiliários que crescem de modo exponencial, configurando hoje, como pode ser denominado, um eixo turístico metropolitano.

A metrópole, com seu núcleo adensado e verticalizado e suas bordas espraiadas e dispersas se reconfigura numa dinâmica comandada pelo capital 
imobiliário, recentemente aliado à empreendedores turísticos internacionais, sem um papel para o planejamento territorial estatal ou municipal, sem instâncias de gestão regional ou metropolitana, sem espaços públicos, com a privatização em curso de todos os espaços, inclusive as praias, apropriados para o uso "turísticoimobiliário" e para habitações precárias e com o crescimento da segregação residencial.

\section{REFERÊNCIAS}

A Tarde, Empresários compram 45 imóveis na área do Sodré, 27/04/2008. Salvador, 2008, pg. 4 e 5.

BRANDÃO, Maria D. de A. O último dia da criação: mercado, propriedade e uso do solo em Salvador. In: VALLADARES, Lícia do P. (org.) Habitação em questão. Rio de Janeiro: Zahar, 1981.

CARVALHO, Inaiá M. M. de; SOUZA, Ângela G.; PEREIRA, Gilberto C. Polarização e Segregação Socioespacial em uma Metrópole Periférica. Caderno CRH, Salvador, v. 17, n. 41, p. 281-297 Mai./Ago. 2004.

CARVALHO, Inaiá Maria Moreira de, PEREIRA, Gilberto Corso (Coordenadores). Como Anda Salvador. Relatório de pesquisa apresentado ao Ministério das Cidade. Salvador, 2005. 109 p.

CARVALHO, Silvana Sá de. Áreas Livres para Ocupação Urbana no Município de Salvador. Dissertação de Mestrado apresentada ao Programa de Pós-Graduação em Arquitetura e Urbanismo da Universidade Federal da Bahia. Salvador, 2002.

MARQUES, Eduardo e TORRES, Haroldo. (Orgs.). São Paulo: segregação pobreza e desigualdades sociais. São Paulo: Editora SENAC São Paulo, 2005, 329 p.

PEREIRA, Gilberto Corso. Atlas Digital Salvador. Salvador: LCAD/UFBA, 2000. CD-ROM.

PEREIRA, Gilberto Corso. Habitação popular em Salvador: o caso das Malvinas. Dissertação de mestrado apresentada ao Programa de Pós-Graduação em Arquitetura e Urbanismo da Faculdade de Arquitetura da Universidade Federal da Bahia, 1989.

Prefeitura Municipal de Salvador / Secretaria de Habitação. Vazios Urbanos com Potencial de Implantação de Empreendimentos Habitacionais de Interesse Social: Relatórios. Salvador, 2007.

Prefeitura Municipal de Salvador. Plano Diretor de Desenvolvimento Urbano - PLANDURB: EPUCS: uma experiência de planejamento urbano. Salvador, 1976.

REIS, N. G. Notas sobre urbanização dispersa e novas formas de tecido urbano. São Paulo: Via das Artes, 2006.

SAMPAIO, Antonio Heliodório Lima. Formas Urbanas: cidade real \& cidade ideal, contribuição ao estudo urbanístico de Salvador. Salvador: Quarteto Editora/PPG-AU, Faculdade de Arquitetura, 1999. 432 p.

SILVA, Sylvio Bandeira de Mello. Reavaliando os principais problemas de Salvador. Cadernos de Geociências, Salvador: Instituto de Geociências da UFBA, v.5, nov., p.43-58, 1996.

SOUZA, Ângela Gordilho. Limites do habitar, segregação e exclusão na configuração urbana contemporânea de Salvador e perspectivas no final do século XX, Salvador: EDUFBA, 2000.

SOUZA. Ângela Gordilho. As cidades na cidade -Aventuras do capital e do trabalho na produção do espaço de Salvador. In: Quem Faz Salvador. Pró-Reitoria de Extensão da UFBA, 2002, p. 167-180. 



\title{
CONDIÇÕES DE VIDA, VIOLÊNCIAS E EXTERMÍNIO
}

\author{
Jairnilson Silva Paim*
}

Sei que é sonho Incomodado estou, num corpo estranho Com governantes da América Latína Notando meu olhar ardente Em longínqua direção Julgam todos que avisto alguma salvação Mas não, é a tí que vejo na colina.'

\section{INTRODUÇÃO}

Distintos são os olhares voltados para as cidades, seja o do poeta - ardente em longínqua direção -, ressaltando suas belezas e suas misérias, seja o das disciplinas que buscam objetivações técnico-científicas.

Como a Saúde Coletiva poderia olhar a cidade? Explorando, talvez, a sua potencialidade interdisciplinar, através da economia política do espaço urbano, da geografia crítica e de uma etno-epidemiologia, de forma a tentar decifrar o modo de vida das pessoas nos territórios-processo, incluindo suas contradições e possibilidades histórico-políticas de engendrar, no presente, futuros alternativos. Daí a lembrança da lição segundo a qual "quando quisermos definir qualquer pedaço do território, deveremos levar em conta a interdependência e a inseparabilidade entre a materialidade, que inclui a natureza, e o seu uso, que inclui a ação humana, isto é, o trabalho e a política." (Santos; Silveira, 2000, p.247).

O caráter histórico desse espaço torna-o um "território vivo", ou "território

\footnotetext{
* Professor titular do Instituto de Saúde Coletiva da Universidade Federal da Bahia. Pesquisador 1-A do CNPq. Partes deste estudo, que tem o apoio do CNPq, foram apresentadas no VII Congresso Brasileiro de Saúde Coletiva, realizado em Brasília, em agosto de 2003, e no VI Congresso Brasileiro de Epidemiologia, em Recife, em junho de 2004
}

${ }^{1}$ Chico Buarque, Sonhos são sonhos. In: Buarque, C. As cidades (BMG). 
utilizado", onde se expressam interesses, divisão do trabalho, movimentos sociais e de capitais, residências de pessoas, lazer, cultura e poderes diversos. Salvador traz, na constituição do seu espaço urbano, as marcas da sua história, as características fundamentais da urbanização brasileira - como a recriação da pobreza e, em tempos de globalização, a reprodução ampliada da miséria: novos pobres no meio da nova riqueza (Santos; Silveira, 2001). Os catadores de lixo e a epidemia da violência são emblemáticos nos tempos de agora.

Nessa nova ordem mundial, os exércitos industriais de reserva, funcionais no surgimento do capitalismo, já podem ser dispensados da produção (Véras, 2003) e, em termos teóricos, parece que pouco ajudam enquanto categoria de análise. Como analisar esse fenômeno que torna milhões de seres humanos supérfluos ou descartáveis na etapa atual do capitalismo globalizado? (Carvalho, 2003). Como anda Salvador nesse contexto? Como a Saúde Coletiva poderia analisar as violências, não do ponto de vista da criminalidade, da delinqüência e da segurança pública, mas contemplando "as formas culturalmente naturalizadas de agressões interpessoais, de discriminações raciais e contra grupos específicos, como homossexuais, de abusos e de dominação"? (Minayo, 2003, p.43).

Este livro busca refletir sobre algumas dessas questões, e o presente capítulo tem como objetivo analisar a distribuição dos homicídios no espaço urbano da cidade do Salvador, discutindo os significados sociais desse tipo violência. Partese do pressuposto, segundo o qual, em cada território que integra a cidade, 0 capitalismo da nova ordem produz iniqüidades sociais que se expressam nos diferenciais intra-urbanos de mortalidade por homicídios. Assim, as condições de vida, enquanto acumulações sociais, podem contribuir para a explicação da distribuição desigual das mortes violentas no espaço urbano.

\section{VIOLÊNCIA LETAL EM SALVADOR}

A violência é qualquer ação intencional realizada por um indivíduo ou grupo, dirigida a outro, que resulte em óbito, danos físicos, psicológicos e/ou sociais (Franco, 1992). É um ato consciente, orientado, elaborado, simbólico, que se dá em um determinado ordenamento econômico e social (Minayo, 1994). Pode ser entendida, também, como uma construção política, decorrente do jogo de interesses em confronto na vida social (Espinheira, 2000). 0 crescimento das violências nas metrópoles brasileiras tem sido reconhecido como um dos mais importantes problemas sociais, ao lado do desemprego, e como questão de saúde pública (Minayo, 1994; Peres, 2004).

Diante da natureza complexa desse fenômeno e das dificuldades para sua definição, tende-se a optar pela expressão "violências", em lugar de "violência" (Minayo, 2003). Assim, pesquisa realizada nas páginas policiais dos principais jornais da Bahia, em 1999, apontava distintas violências: 319 assaltos a ônibus, 221 
acidentes de trânsito, 38 estupros e 9 linchamentos, além de centenas de homicídios (Carvalho, 2001). Estes últimos representam uma das expressões mais dramáticas dessas violências. Portanto, priorizar os homicídios justifica-se pelo fato de delimitar melhor o problema de pesquisa e de intervenção (Paim, 2002), e por se tratar de uma violência letal, que subverte o direito à vida.

Ainda que Salvador apresente taxas inferiores às de outras capitais brasileiras, tais como Rio de Janeiro, São Paulo e Recife, constatou-se um acelerado ritmo do seu crescimento na passagem da década de oitenta para a de noventa (Mello Jorge et al., 1997). Assim, os homicídios têm ocupado o primeiro lugar entre as causas de morte violenta, constatando-se uma maior mortalidade masculina para todas as faixas etárias, especialmente entre adolescentes e adultos jovens, além de uma desigualdade social diante do risco de morrer (Almeida, 1998; Paim et al., 1999; Macedo et al., 2001).

$\mathrm{Na}$ análise dos tipos de causas externas de morte, em Salvador, tem-se constatado o envolvimento de policiais na ocorrência de homicídios, mesmo sem evidências de se tratar de intervenções legais, tal como disposto na Classificação Internacional de Doenças, da Organização Mundial da Saúde (OMS, 1985): "Iesões infligidas pela polícia ou por outros agentes da lei, incluindo militares em serviço, durante detenção ou tentativa de detenção por infração da lei, para repressão de distúrbios, para a manutenção da ordem pública e outras ações legais" (CID, E970979). Exclui-se, portanto, as execuções sumárias e clandestinas, os massacres e os atos de extermínio. Em tais situações preferiu-se utilizar a expressão "intervenções legais" (entre aspas) ou intervenções policiais diante da dificuldade de aplicar os critérios da OMS.

No início da década de noventa, esses óbitos representavam $7 \%$ do conjunto da mortalidade por causas externas, em Salvador, e uma em cada dez mortes violentas de crianças e adolescentes (Paim et al., 1996, 1999). Nesse tipo de violência, apenas $1 \%$ das mortes teve como vítimas pessoas de cor branca (Santos et al., 2000), ou seja, a maior parte dos homicídios decorrentes da intervenção policial, na cidade do Salvador, atingiu aos negros e aos mulatos (Gráfico 1).

Essas vítimas tinham, geralmente, o primeiro grau incompleto (Gráfico 2), sofreram a ação letal de armas de fogo em mais de $85 \%$ dos casos (Gráfico 3 ) e residiam, especialmente, nos distritos sanitários do Subúrbio Ferroviário e no miolo da cidade, a exemplo dos distritos de São Caetano/Valéria, Liberdade e Cabula (Santos et al., 2000).

No conjunto dos homicídios, a análise espacial ${ }^{2}$ indica que os coeficientes

\footnotetext{
${ }^{2}$ Para a realização da análise da distribuição geográfica desses óbitos, recorreu-se ao mapeamento elaborado pela Companhia de Desenvolvimento da Região Metropolitana de Salvador (CONDER), que divide a Cidade do Salvador em 75 Zonas de Informação (ZI), considerando critérios urbanísticos e socioeconômicos. Essas ZI são compatibilizadas com os setores censitários (CS) definidos pelo IBGE (Paim et al., 1999). As fontes de dados foram a Secretaria de Saúde do Estado da Bahia (SESAB) e o Instituto Médico Legal Nina Rodrigues (IMLNR).
} 
Gráfico 1 - Proporção de óbitos por "Intervenções Legais" segundo a cor do indivíduo.

Salvador, 1994

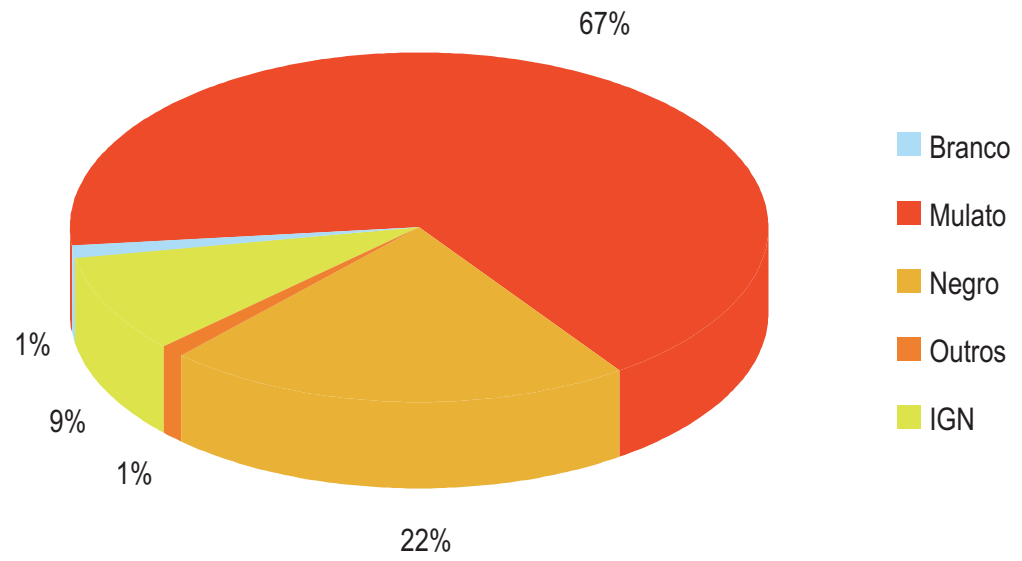

Fonte: SESAB/IMLNR

160) Gráfico 2 - Proporção de óbitos por "Intervenções Legais" segundo o grau de instrução da vítima.

Salvador, 1991 e 1994

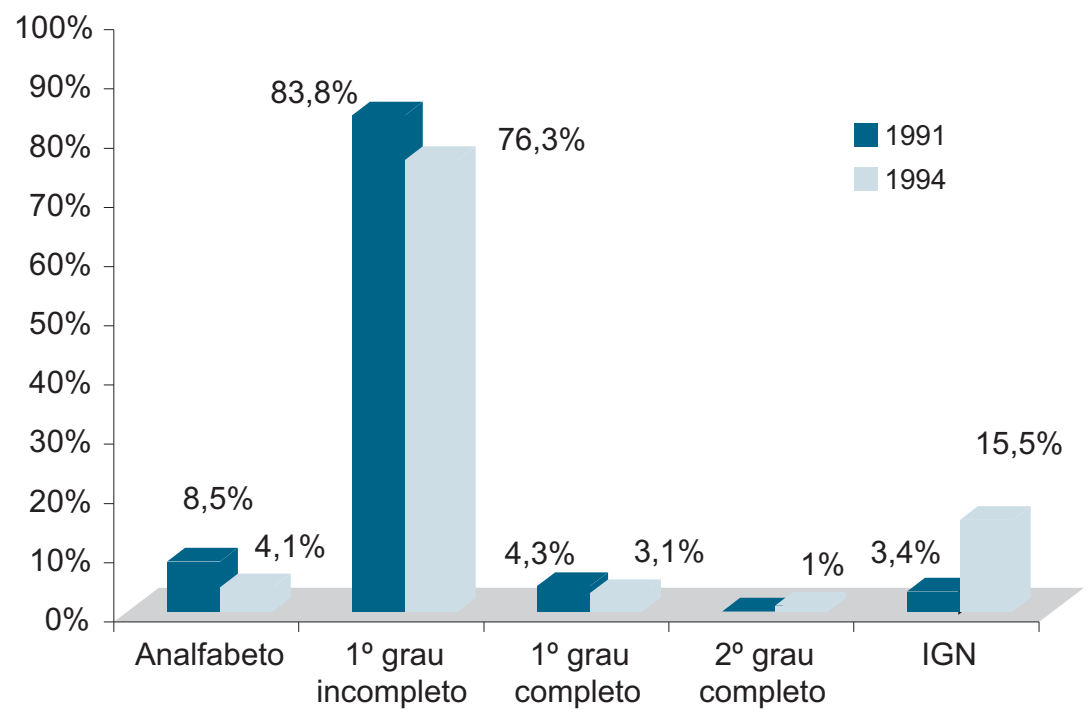

Fonte: SESAB/IMLNR 
mais elevados, em 1997, corresponderam às zonas da Liberdade (80,5\%00), Valéria (79,5\%00), Engomadeira (75,2\%00) e Nordeste de Amaralina (64,9\%00). Em 2000, os valores mais altos foram encontrados nas áreas de Pirajá $(73,1 \% 00)$, IAPI (53,6\%00), Nordeste de Amaralina (44,3\%00), Escada/Periperi/Praia Grande $(43,7 \% 00)$ e Valéria $(42,7 \% 00)$. Apenas o Nordeste de Amaralina, em ambos os anos do estudo, integra a orla da cidade. As demais se inserem no na parte mais central e no Subúrbio Ferroviário (Nunes; Paim, 2005).

Todas as áreas citadas correspondem às Zonas de Informação (ZI) com piores condições de vida da Cidade do Salvador, apresentando valores de ICV 3 elevados (Anexos 1 e 2). Os residentes nessas áreas têm risco quase duas vezes maior de morrer por homicídio do que os habitantes de bairros cujas ZI conformavam estratos de melhores condições de vida (Gráfico 4).

As populações residentes em áreas que compuseram o estrato de $\mathrm{ZI}$ com melhores condições de vida apresentaram coeficientes de 20,1 e 13,5 óbitos por homicídio, para cada 100.000 habitantes, em 1997 e 2000, respectivamente. Já

Gráfico 3 - Proporção de óbitos por "Intervenções Legais" segundo o instrumento utilizado Salvador, 1991 e 1994

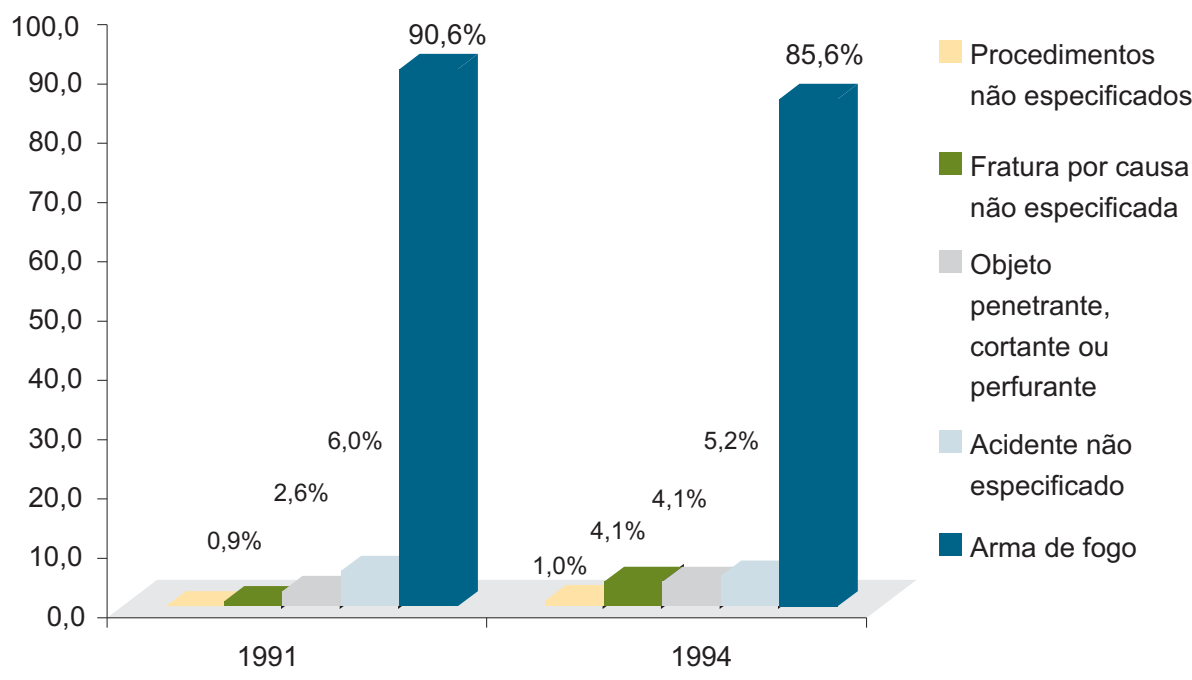

Fonte: SESAB/IMLNR

${ }^{3}$ O Índice de Condições de Vida (ICV) é calculado para cada zona de informação (ZI), utilizando-se cinco indicadores relativos às variáveis proxy de condições de vida, que foram obtidas mediante tabulações especiais do Censo de 1991, a saber: a) proporção de chefes de família em domicílios particulares permanentes, com rendimento médio mensal igual ou inferior a dois salários mínimo; b) proporção de pessoas de 10 a 14 anos alfabetizadas; c) percentagem de casas de "aglomerado subnormal" em relação ao total de domicílios; d) razão entre o número médio de moradores, por domicílio, na Zl e o número médio de cômodos servindo de dormitório na respectiva Zl; e) porcentagem de domicílios com canalização interna, ligado à rede global de abastecimento de água. Procedeu-se à distribuição das ZI em ordem crescente dos 
as ZI que formaram os estratos com piores condições de vida exibiram, no mesmo período, taxas de 37,9\%00 e 23,6\%00, respectivamente (Gráfico 4).

Todavia, o exame da evolução desses indicadores, no final da década de noventa, sugere um decréscimo das taxas de homicídios nos diferentes estratos, especialmente 03 e $\circ 4$ (Gráfico 4). Nos estratos de piores condições de vida, somente Pirajá, São Gonçalo do Retiro, Sussuarana e Estrada CIA/Aeroporto apresentaram taxas ascendentes no período do estudo. Nordeste de Amaralina e Mata Escura apresentaram queda em 2000. Já nas ZI que integraram o estrato de melhores condições de vida, observam-se taxas crescentes na Pituba e Barra, além de Piatã/Patamares e Canela, que tinham coeficientes zero, em 1997, e exibiram taxas de 15,5\%00 e 34,9\%00 em 2000 (Nunes; Paim, 2005). Embora tais resultados devam ser examinados com certa cautela, diante da possível instabilidade dos indicadores, não deixam de chamar a atenção para certos deslocamentos na distribuição espacial da violência.

Gráfico 4 - Taxa de mortalidade por homicídio (/1000.000hab.)

segundo estratos de condições de vida - Salvador, 1997 e 2000

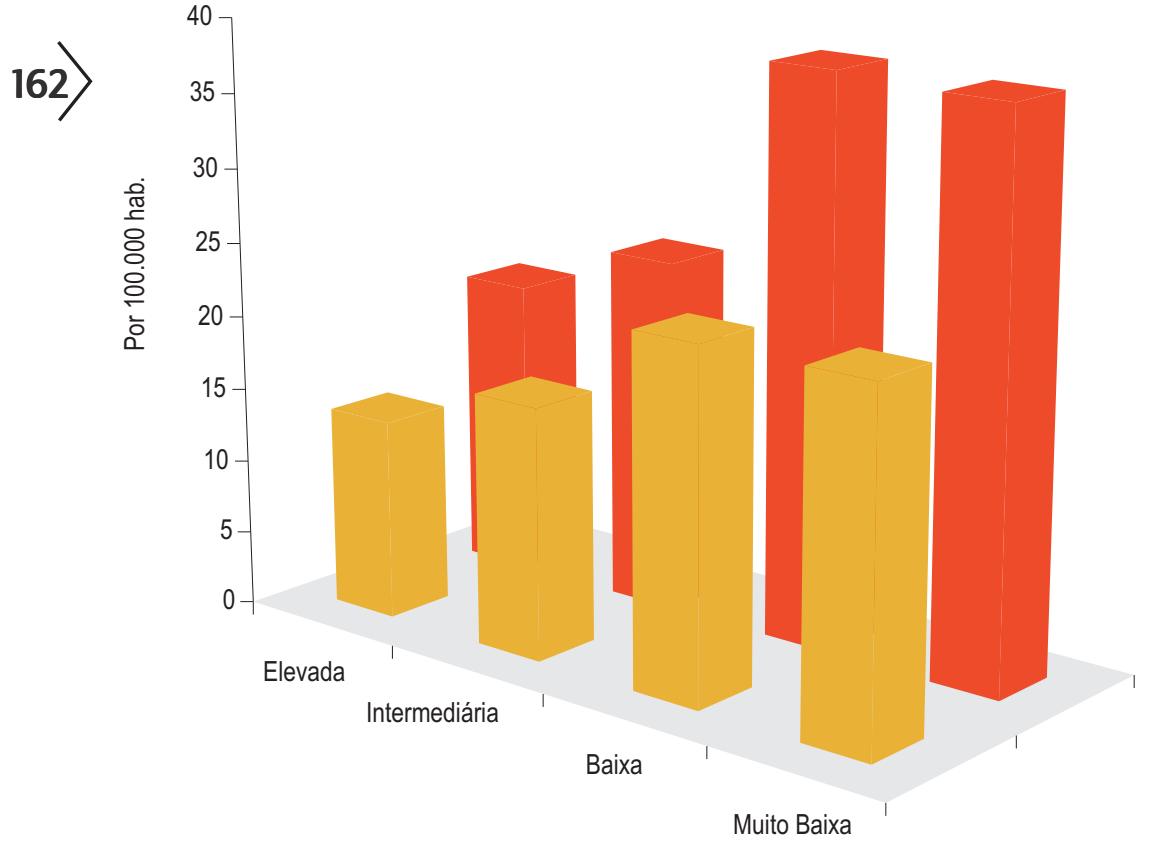

Fonte: SESAB/IMLNR

escores dos respectivos ICV e agregação das mesmas em quartis, correspondentes aos estratos de "elevada", "intermediária", "baixa" e "muito baixa" condições de vida. Assim, ICV elevado significa que a Zl ocupou os últimos lugares no ranking dos cinco indicadores utilizados, enquanto ICV baixo indica que a Zl correspondente encontrava-se nos primeiros lugares da lista de indicadores (Paim, 1997). 
No artigo mencionado (Nunes; Paim, 2005), associou-se uma abordagem qualitativa à investigação epidemiológica. A partir do monitoramento dos diferenciais intra-urbanos das mortes violentas, realizado nos anos de 1988, 1991, 1994, 1997 e 2000 (Paim et al., 1999; Freitas et al., 2000; Macedo et al., 2001), desenvolveu-se um estudo etnográfico de uma área que exibiu redução das taxas após experimentar aumento das mesmas ao longo de cinco anos. Essa abordagem permitiu evidenciar a dinâmica social subjacente entre o primeiro período (1988 e 1994) e o segundo (1994 e 2000).

A hipótese que orientou a investigação realizada centrava-se na possibilidade de existência de práticas de extermínio, contando ou não com a participação da polícia. Os fragmentos de narrativas obtidos no referido estudo ilustram o que não é revelado nem nas estatísticas oficiais, nem pelos estudos epidemiológicos realizados até então.

$P$ - Você chegou a conhecer esse pessoal?

$R$ - Cheguei, tinha um bar aqui. Ai, quando um rival se cruzasse um com o outro, não tinha quem ficasse, era tipo bangue-bangue.

$P$ - Eles eram envolvidos com o quê?

$R$ - Era ladrão perigoso.

$P$ - E aconteceu o quêcom ele?

$R$ - Era um ladrão perigoso, mas decente, legal mesmo, viu?

$P$ - Como assim, com as pessoas?

$R$-Com as pessoas, respeitava todo mundo. Se acontecesse alguma coisa, alguém batesse, ele defendia. Se caso o ladrãozinho ali, roubasse aquela casa, e ele chegasse agora, ele ia entregar; se caso ele fosse assaltar um ônibus, você que está dentro, é conhecida, ele vai te assaltar, chegasse aqui ele te devolvia.

$P$ - Então, aqui no bairro, ele protegia as pessoas e era mais fora que ele fazia as coisas?

$R$ - Não merecia morrer não, viu? Uma pessoa ótima.

Esse estilo "bandido-herói", ou "Charles Anjo 45, protetor dos fracos e dos oprimidos", ao tempo em que substituía a ação estatal, estabelecia novas regras de convivência na localidade.

$P$ - E esse pessoal que era morto era o quê?

$R$ - Erabandido.

$P$ - Bandido?

$R$ - Pelo comentário que eu ouvia é que era bandido, era ladrão e o povo linchava... (risos).

$P$ - Tinha muito linchamento aqui?

$R$ - Era, tinha muito, é. Tanto que aqui, quando se falava nesse bairro, já viu, né!

Porque, na época de 86 a 91, o crime aqui estava demais, demais. Aí, então, através da população, sobre o linchamento, aí excluiu mais esse negócio de vagabundagem, 
de roubo. Você não podia dormir com sua porta em paz, eles iam e arrombavam, e hoje não, graças a Deus, não acontece mais isso.

$P$ - Os marginais, eles moravam aqui no bairro?

$R$ - A maioria morava, uma minoria vinha de fora.

$P$ - Você acha que a população se organizou e contratava serviços, ou ela mesma... você viu muitos linchamentos, essas coisas, nesse período que você falou que teve?

$R$ - Visim.

$P$-Com mortes?

$R-\operatorname{Sim}$.

Múltiplas eram as formas referidas pelos entrevistados, matadores contratados e grupos de extermínio pagos; armadilhas ("botes") concebidas com a participação da polícia; moradores se empenhando em fazer justiça com as próprias mãos.

$\mathrm{R}$-É, por exemplo, eu passando, eu passando e eles abordando: o grupo de extermínio abordando já o cara. Mas também não conhecia o cara nem nada, abordando o cara e botando dentro do carro e dizendo que ia levar pro matadouro: "Você vai morrer! Você vai morrer!" E aquele desespero, e eu passando na hora, eu e meus amigos, a gente parou, com medo, e a gente ficou naquela coisa: "Será que eles vão pegar a gente também?" A gente aí passou em alta, de bike, e aí subimos pela invasão e aí viemos embora e aquela coisa ficou gravada na mente... Aí eu digo "Rapaz!" - eu nunca tinha visto, eu nunca tinha assistido assim, é feio mesmo na hora, os caras puxando o cara: "Não! Pelo amor de Deus, não me mate não! Eu não fiz nada! Não sei o quê!", "Entre no carro logo!" - o cara não queria entrar no carro... "Entra logo! Vam'bora!", o pessoal começou a olhar, um aglomerado de gente começou a chegar, e eles agem na cara de pau, não tão nem aí. Eu não sei se tão drogados também, se tão bêbados também, o meio que eles acham pra se divertir é tirar a vida de uma pessoa! Eu acho que ninguém tem o direito de tirar a vida de ninguém!

O ritual do extermínio descrito por esse entrevistado supera em crueldade qualquer estética de violência produzida pelas artes e, particularmente, pelo cinema.

\section{VIOLÊNCIA E DESIGUALDADES NAS CONDIÇÕES DE VIDA}

A análise da distribuição espacial da mortalidade por homicídios, em Salvador, no final dos anos noventa, apontou zonas da cidade com coeficientes muito elevados, em relação a outras localidades do Brasil (Waiselfisz, 2002). 0 aumento progressivo do risco de morrer, a partir das zonas que compuseram 0 estrato de melhores condições de vida até àquelas que formaram o estrato com piores condições, nos anos de 1997 e 2000, bem como os coeficientes de homicídio mais elevados nas áreas que apresentaram más condições de vida, reforçam as correntes explicativas que apontam as desigualdades sociais como um dos maiores 
responsáveis pela magnitude da violência nas cidades brasileiras (Souza; Minayo, 1995; Macedo et al., 2001). Todavia, a relação entre desigualdades nas condições de vida e homicídios não deve ser compreendida de forma linear e unívoca (Lima; Ximenes, 1998; Souza et al., 2005), já que outras variáveis precisam ser consideradas, embora nem sempre quantificáveis.

No caso dos homicídios relacionados às "intervenções legais", parece existir uma outra relação que não é exclusivamente dependente das condições de vida. Trata-se da discriminação racial, que penaliza os negros da cidade (Ribeiro, 2000), e que precisa ser investigada e enfrentada de modo mais sistemático.

Como já se ressaltou em outras oportunidades, os resultados dos estudos epidemiológicos utilizando desenhos ecológicos não permitem indicar bairros violentos, como sugere a mídia e o senso comum, nem concluir que a pobreza, em si, gere violência. As investigações realizadas baseiam-se no local de residência registrado no atestado de óbito e não no lugar de ocorrência da agressão. Pode-se admitir, sim, o fato de que as populações residentes nas áreas mais pobres de Salvador são as maiores vítimas das violências letais. $E$ as evidências produzidas apontam as desigualdades sociais como matriz explicativa dos diferenciais intraurbanos das taxas de homicídio na cidade.

Contudo, os resultados do presente estudo revelam um decréscimo dessas taxas nas diferentes áreas da cidade, o que requer novas análises à luz da evolução dos indicadores socioeconômicos. Mesmo que tais resultados sugiram uma melhora da situação, em termos médios, das Zls que constituíram os estratos de condições de vida, cabe registrar a manutenção da gravidade em certas zonas da cidade. Assim, o estudo etnográfico realizado em uma dessas áreas indicou que, no primeiro período, ocorreu um extermínio de muitas pessoas consideradas delinqüentes e 0 assassinato de muitos moradores no bairro, o que, nos estudos epidemiológicos anteriores, corresponde a um aumento na taxa de mortalidade por causas externas (Freitas et al., 2000). Entre 1991 e 1994, constatou-se um decréscimo da taxa de homicídios, coincidindo, no trabalho de campo, com o período considerado de acalmia. Já entre 1997 e 2000, verifica-se novamente um aumento da taxa de homicídio no bairro pesquisado. Embora os moradores ainda façam referência a uma imagem pacífica do bairro, as narrativas indicaram crescimento da violência na presente década, embora em níveis menos elevados que no final dos anos 80.

No bairro onde foi realizado o estudo de campo, constatou-se pouca organização comunitária, um número reduzido de programas sociais, a ausência do poder público e a reorganização do tráfico de drogas (Nunes; Paim, 2005). Esse apartheid sanitário representa um dos enigmas a serem decifrados para a formulação de políticas públicas nas cidades. Assim, a pergunta central é: como implementar tais políticas, mantendo o padrão de desigualdades sociais e a segmentação do sistema de proteção social e, em particular, do sistema de saúde por tempo indeterminado? 


\section{O QUE FAZER?}

As políticas de saúde que apostam em modelos de atenção ou em modos tecnológicos de intervenção, a exemplo da promoção e vigilância da saúde, da saúde da família e das cidades saudáveis poderiam ser uma das alternativas para cuidar das pessoas e do ambiente, favorecendo a ação social organizada (Paim, 2003). Além disso, poderiam contribuir para a constituição de sujeitos sociais capazes de exercer um protagonismo na vida social e intervir na estrutura de poder das cidades.

Considerando o impacto das armas de fogo sobre a violência no Brasil, (especialmente a crescente mortalidade na década de noventa) ao lado das repercussões na morbidade (Peres, 2004), torna-se justificável reforçar as medidas de controle sobre esse fator de risco, sem prejuizo das demais estratégias intersetoriais de prevenção e de redução das desigualdades. Assim, políticas públicas nos campos da cultura, reforma e gestão urbana, moradia, saúde, geração de emprego e renda, saneamento ambiental, educação, segurança pública e justiça têm sido propostas nessa perspectiva, como se verifica na Carta de Brasília, formulada durante a IV Conferência das Cidades, em 2002 (Câmara dos Deputados, 2003).

Ao problematizar o social e a violência em cidades como Salvador, seria pertinente considerar algumas "idéias-elementos" (Santos, 1999) para orientar novas investigações. Assim, a noção de complexidade permitiria uma aproximação com a realidade através da análise dos feixes de relações e da heterogeneidade do espaço social, reconhecendo a diversidade dos fenômenos históricos e sociais. Admitindose a historicidade dos processos e conflitos sociais sublinham-se as práticas sociais cujos resultados encontram-se em um "campo de possíveis" e não determinados. Os conceitos de processo social e de relações sociais, por sua vez, possibilitariam "situar as redes de dominação presentes nas formações sociais, sejam processos de exploração econômica, sejam processos de disciplinarização, as quais são acompanhadas por ações de violência simbólica e física" (Santos, 1999, p.12). Finalmente, a oposição regra/conflito valorizando os pólos da contradição e da luta, ao invés da ordem e do consenso, estimularia o exercício de uma "sociologia da conflitualidade" no contexto da globalização da sociedade e da economia. Essa abordagem seria capaz de investigar "formas sociais marcadas pelos efeitos excludentes das políticas neoliberais, desencadeando novos conflitos sociais e, por vezes, ameaçando a consolidação da democracia nos países periféricos do mundo capitalista" (Santos, 1999, p.13).

Esse quase programa de pesquisa interdisciplinar, além de contribuir para a superação dos olhares parciais das disciplinas técnico-científicas que se debruçam sobre as cidades e, neste caso, sobre a violência urbana, superaria os limites da explicação local. Nesse particular, faz-se necessário entender o "panorama do crime organizado internacionalmente, do crime também ele globalizado, com suas características econômicas, políticas e culturais sui generis, sem perder algo do velho capitalismo, da busca desenfreada do lucro a qualquer preço" (Zaluar, 1999, p. 94). 
No caso de Salvador, a não disponibilidade de evidências que apontem para a melhoria das condições de vida da população ou para a redução das desigualdades sociais no período do estudo justifica, ainda, a necessidade de investigações para a análise de implantação de programas e projetos em curso (Noronha et al., 2000; Espinheira, 2004), dirigidos para a redução das violências.

Para além da produção de conhecimentos, resta identificar os sujeitos sociais potentes para o enfrentamento das contradições do espaço urbano, como "dever moral" ou uma "necessidade radical" (Heller, 1986), que mobilizem os meios políticos capazes de superar a situação social vigente. Mesmo sem otimismos tolos ou esperanças infundadas, cabe examinar os movimentos para além do plano fenomênico da realidade, analisando as contradições que se avolumam nas metrópoles e vislumbrar, dialeticamente, novas acumulações e potencialidades sociais:

Amplia-se a variedade de tipos econômicos, culturais, religiosos e lingüísticos, multiplicam-se os modelos produtivos, de circulação e de consumo, segundo qualificações e quantidades, e também aumenta a variedade de situações territoriais (...) Nessas condições, a metrópole está sempre se refazendo: na forma, na função, no dinamismo e no sentido. Essa riqueza do inesperado constitui a possibilidade de construção de novos futuros. (Santos; Silveira, 2001, p.287).

No final do século XX, realizou-se, no Brasil, uma importação da noção de exclusão social (Véras, 2003), termo que serve para quase tudo, inclusive para dar boa consciência a propostas de "inclusão", sem alterar os determinantes estruturais do fenômeno nem as políticas econômicas impostas pelo capitalismo globalizado. Assim, noções como exclusão e segregação social emergem nos países do primeiro mundo quando se deparam, nessa nova ordem, com a nova pobreza e com a miséria, velhas conhecidas das cidades da América Latina. A metrópole parisiense, por exemplo, tem concentrado a riqueza mais extrema junto à maior pobreza e à complexidade da estrutura socioespacial, quando os preços fundiários e imobiliários produzem a segregação dos mais pobres nos espaços mais desvalorizados (Préteceille, 2003). Nesse contexto, as políticas públicas implementadas há mais de quinze anos não impediram as revoltas e destruições nos seus subúrbios a partir de 27 de outubro. ${ }^{4}$ Essa riqueza do inesperado pode representar um sinal dos tempos, quiçá de novos futuros.

\section{REFERÊNCIAS}

ALMEIDA, L. M. A. de. Violência e condições de vida em Salvador: diferenciais intra-urbanos da mortalidade por homicídios em 1991 e 1994. 1998. 92 p.+ anexos. Dissertação (Mestrado) - ISC/UFBA, Salvador, CÂMARA DOS DEPUTADOS. A cidade cidadã: as diversas formas de superação da violência. In: CONFERÊNCIADAS CIDADES, 4 RELATÓRIO FINAL. Brasilia: Coordenação de Publicações, 2003. 126 p.

${ }^{4}$ Ver: O COLAPSO das cidades. Folha de São Paulo, 13 nov., 2005. Caderno Mais, São Paulo. 
CARVALHO, I. Cidades. Caderno CRH: revista do Centro de Recursos Humanos da UFBA, Salvador, n. 38, p. 21-26, 2003.

CARVALHO, J. A. de (Org.) Salvador: cidade repartida. Salvador: Sindicato dos Bancários, 2001. 145 p. ESPINHEIRA, G. Os tempos e os espaços do crime. In: OLIVEIRA, N. de; RIBEIRO, L. M. S.; ZANETTI, J. C. (Orgs.). A outra face da moeda: violência na Bahia. Salvador: Comissão de Justiça e Paz da Arquidiocese de Salvador, 2000. p.30-43.

. (Coord.). Sociabilidade e violência: criminalidade no cotidiano de vida dos moradores do Subúrbio Ferroviário de Salvador. Salvador: Ministério Público do Estado da Bahia, Universidade Federal da Bahia, 2004. 204 p.

FRANCO, A. S. La violencia, problema y reto para la salud pública. Violencia contra la mujer, un problema de salud pública (Memoria) In: SEMINARIO SUBREGIONAL SOBRE VIOLENCIA CONTRA LA MUJER,1,11-14 marzo, 1992. Manágua (Nicarágua).

FREITAS, E. D. de; PAIM, J. S.; VIEIRA DA SILVA, L. M.; COSTA, M. da C. N. Evolução e distribuição espacial da mortalidade por causas externas em Salvador, Bahia, Brasil. Caderno Saúde Pública, Rio de Janeiro, v. 16, n. 4, p.1059-1070, 2000.

HELLER, A. Teoría de las necesidades en Marx. Barcelona: Ediciones Península, 1986. 182p.

LIMA, M. L. C. de; XIMENES, R. Violência e morte: diferenciais da mortalidade por causas externas no espaço urbano do Recife. Caderno Saúde Pública, Rio de Janeiro, v. 14, n. 4, p. 829-840, 1998.

MACEDO, A. C.; PAIM, J. S.; VIEIRA DA SILVA, L. M.; COSTA, M. C. N. Violência e desigualdade social: mortalidade por homicídios e condições de vida em Salvador, Brasil. Revista de Saúde Pública, Rio de Janeiro, v. 35, n. 6, p. 515-22, 2001.

MELLO JORGE, M. H. P. de; GAWRYSZEWSKI, V. P.; LATORRE, M. do R. de O. Análise dos dados de mortalidade. Caderno Saúde Pública, Rio de Janeiro, v. 31, Supl. 4, p. 5-25, 1997.

MINAYO, M. C. de S. A violência social sob a perspectiva da saúde pública. Caderno Saúde Pública, Rio de Janeiro, -v. 10, Supl. 1, p. $\theta 7-18,1994$.

. A violência dramatiza causas. In: ; SOUZA, E. R. de (Orgs.). Violência sob o olhar da saúde. A infrapolitica da contemporaneidade brasileira. Rio de Janeiro: Editora Fiocruz, 2003. p. 23-47.

NORONHA, C. V.; MACHADO, E.; PAIM, J. S.; NUNES, M. Plano intersetorial e modular de ação para a promoção da paz e da qualidade de vida na cidade do Salvador. Salvador: ISC/UFBA, maio 2000. 52 p. + anexos.

NUNES, M.; PAIM, J. S. Um estudo etno-epidemiológico da violência urbana na cidade de Salvador, Bahia, Brasil: os atos de extermínio como objeto de análise. Caderno de Saúde Pública, Rio de Janeiro, v. 21, n. 2, p. 459-468, 2005.

ORGANIZAÇÃO MUNDIAL DA SAÚDE. Classificação Internacional de Doenças, revisão 1975. São Paulo: Centro da OMS para classificação de doenças em português; Ministério da Saúde; Universidade de São Paulo; OPAS, 1985.

PAIM, J. S. Abordagens teórico-conceituais em estudos de condições de vida e saúde: notas para reflexão e ação. BARATA, R. B. (Org.). Condições de vida e saúde. Rio de Janeiro: ABRASCO, 1997. p. 7-30.

; COSTA, M. da C. N; REQUIÃO, D. A.; COSTA, U. M. M; ARAÚJO, C. B.; MASCARENHAS, J. C.; PEREIRA, S. V. Mortes violentas em crianças e adolescentes de Salvador. Bahia: Análise \& Dados, Salvador, v. 6, n. 1, p. 59-67, 1996.

; MASCARENHAS, J. C. S.; VIEIRA DA SILVA, L. M. Distribuição espacial da violência: mortalidade por causas externas em Salvador (Bahia), Brasil. Revista Panam. Salud Publica/Pan Am. [S.I.], J. Public Health, v. 6, n. 5, p. 321-332, 1999.

. Margens de Salvador: violência e desigualdades sociais no espaço urbano. In: LIMA, P. C. Quem faz Salvador. Salvador: UFBA, 2002. p. 317-319. 
. A reforma sanitária e os modelos assistenciais. In: ROUQUAYROL, M. Z.; ALMEIDAFILHO, N. Epidemiologia e saúde. 6.ed., Rio de Janeiro: 2003. p. 567-586.

PERES, M. F. T. Violência por armas de fogo no Brasil - Relatório Nacional. São Paulo: Núcleo de Estudos da Violência; Universidade de São Paulo, 2004. 196 p.

PRÉTECEILLE, E. A evolução da segregação social e das desigualdades urbanas: o caso da metrópole parisiense nas últimas décadas. Caderno $\mathrm{CRH}$ : revista do Centro de Recursos Humanos da UFBA, Salvador, n. 38, p. 27-48, 2003.

RIBEIRO, L. M. S. Você é negro, jovem e trabalhador? Não venha pra Bahia: morre-se fácil. In: OLIVEIRA, N. de; RIBEIRO, L. M. S.; ZANETTI, J. C. (Orgs.). A outra face da moeda: violência na Bahia. Salvador: Comissão de Justiça e Paz da Arquidiocese de Salvador, 2000. p. 98-100

SANTOS, J. V. T dos. Introdução. Por uma sociologia da conflitualidade. In: SANTOS, J. V. T. dos (Org.). Violência em tempo de globalização. São Paulo: Hucitec, 1999. p. 11-39.

SANTOS, M.; SILVEIRA, M. L. O Brasil: território e sociedade no início do século XXI. Rio de Janeiro: Record, 2001. $471 \mathrm{p}$.

SANTOS, R. L. de; VIEIRA DA SILVA, L. M.; PAIM, J. S.; COSTA, M. C. N. Mortalidade por "intervenções legais" e condições de vida; Salvador, 1991 e 1994. Ciência \& Saúde Coletiva, [S.I.], v. 5, Supl., 2000, p.571. (Livro de resumos).

SOUZA, E. R.; MINAYO, M. C. -de S. O impacto da violência social na saúde pública do Brasil. In: MINAYO, M. C. de S. (Org.) Os muitos brasis. Saúde e população na década de 80. São Paulo: Hucitec, 1995. p. 87-116.

; LIMA, M. L. C. de; VEIGA, J. P. C. da. Violência interpessoal: homicídios e agressões. In: BRASIL. Ministério da Saúde. Secretaria de Vigilância em Saúde. Impacto da violência na saúde dos brasileiros. Brasília: 2005. p. 171-196.

VÉRAS, M. P. B. Sociedade urbana: desigualdade e exclusões sociais. Caderno CRH: revista do Centro de Recursos Humanos da UFBA, Salvador, n. 38, p. 79-114, 2003.

WAISELFISZ, J. Mapa da violência III. Os jovens do Brasil. Brasília: UNESCO; Instituto Ayrton Senna; Ministério da Justiça/SEDH, 2002.

ZALUAR, A. A globalização do crime e os limites da explicação local. In: SANTOS, J. V. T. dos (Org.) Violência em tempo de globalização. São Paulo: Hucitec, 1999. p. 91-100. 
Mapa 1 - Distribuição espacial da taxa de mortalidade (/100.000 habitantes) por homicídio, segundo Zonas de Informação. Salvador, 1997

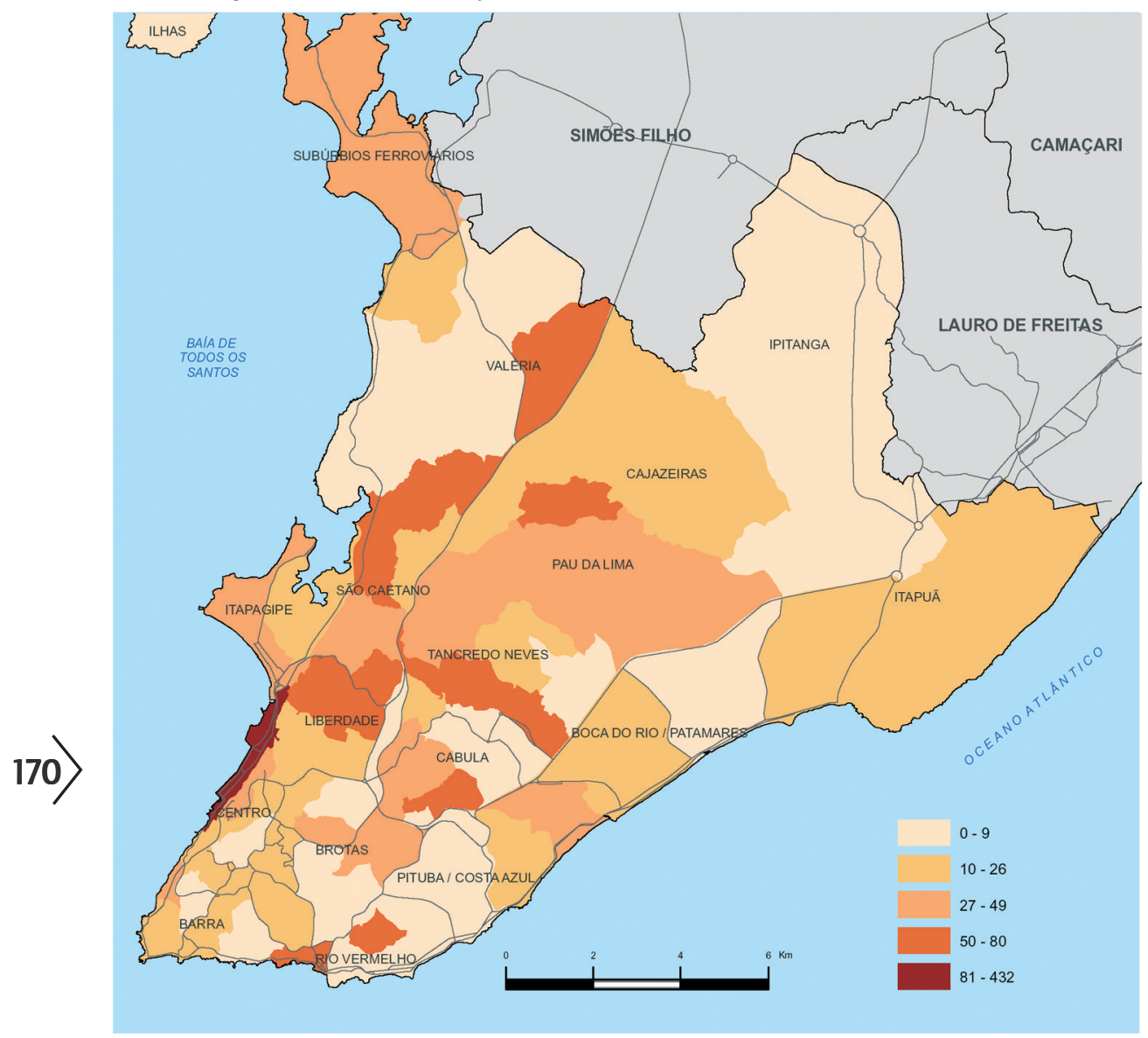

Fonte: Secretaria de Saúde do Estado da Bahia - SESAB

Instituto Médido Legal Nina Rodrigues - IMLNR. Mapa elaborado pelo autor. 
Mapa 2 - Distribuição espacial da taxa de mortalidade (/100.000 habitantes) por homicídio, segundo Zonas de Informação. Salvador, 2000

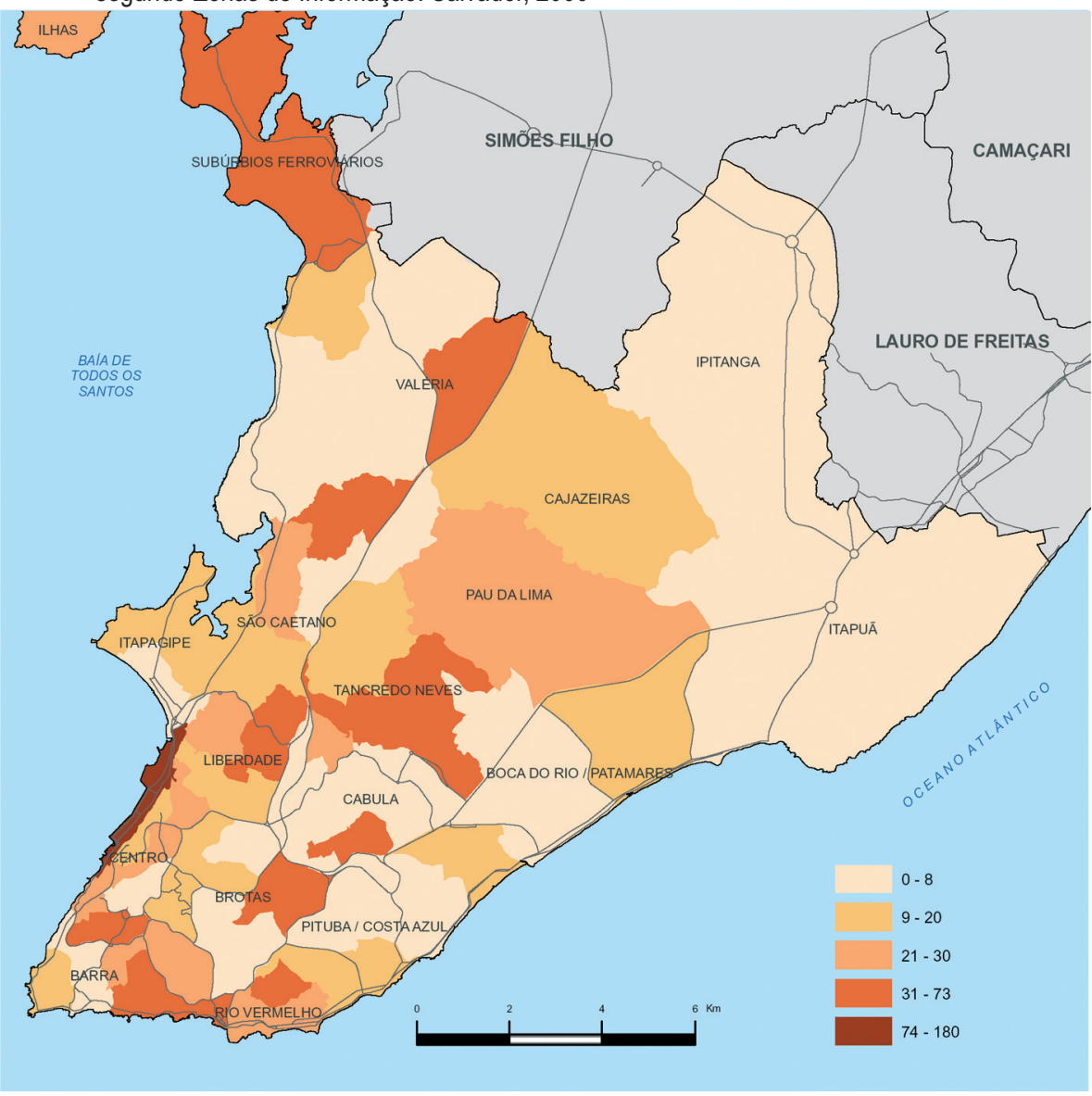

Fonte: Secretaria de Saúde do Estado da Bahia - SESAB

Instituto Médido Legal Nina Rodrigues - IMLNR. Mapa elaborado pelo autor. 



\title{
OS ESPAÇOS PÚBLICOS DA SALVADOR CONTEMPORÂNEA
}

\author{
Angelo Serpa*
}

\section{INTRODUÇÃO}

Salvador, como outras metrópoles do Brasil e do mundo, vem conduzindo políticas de requalificação urbana seletivas e segregacionistas, que reforçam e tornam visíveis as desigualdades sócio-espaciais no tecido urbano-metropolitano. Depois da segunda metade dos anos 1990, a cidade empreendeu uma política sistemática de criação e reabilitação de parques e jardins públicos. Não por acaso, esse período coincide com duas importantes mudanças relativas ao conjunto das grandes cidades do mundo e, em particular, daquelas situadas nos países ditos "emergentes", onde esses fenômenos vão ocorrer com mais intensidade (Serpa, 2006; 2007a).

A primeira corresponde a uma nova ideologia cuja origem situa-se no continente europeu: as noções de desenvolvimento e da cidade "sustentáveis" (Emelianoff, 2004). O princípio de base se apóia na idéia de que a melhoria da qualidade de vida urbana valoriza a imagem e a atratividade das cidades, as áreas "verdes" e públicas servindo a esse fim.

A segunda mudança está relacionada com a evolução sócio-econômica do Brasil. Se os anos 1970-1980 foram marcados pelo aumento do poder (econômico e político) das classes médias, em meados dos anos 1990 assiste-se, nas maiores aglomerações urbanas do país, a um aumento expressivo das desigualdades entre ricos e pobres.

Esta evolução encontra reflexo na paisagem urbana, que testemunha 0 surgimento de novos bairros residenciais servidos de centros comerciais e boa infra-estrutura urbana, do mesmo tipo que aqueles encontrados nas cidades dos países mais prósperos.

*Professor associado do Departamento de Geografia da Universidade Federal da Bahia. Doutor em Geografia. Pesquisador do CNPq. 
A estratégia de promoção de uma imagem positiva de Salvador através da revalorização de seus espaços públicos faz parte do receituário do planejamento estratégico, modelo que aposta na criação de holdings, consórcios ou empresas mistas para executar ações de desenvolvimento urbano. Tanto a requalificação como a adoção de espaços públicos por empresas privadas segue a lógica da visibilidade e da expectativa de retorno através da propaganda e do marketing. 0 problema é que esses programas não atendem, via de regra, às áreas periféricas e de urbanização popular da cidade, onde 0 abandono de parques e praças é notório.

Agentes públicos e privados vêm conduzindo desde então uma política urbana que consiste na "encenação" de determinados espaços públicos, que passam a desempenhar um papel de "vitrine" no contexto urbano. É evidente que estes projetos, programas e intervenções são realizados em função de estratégias de valorização do solo urbano, em bairros com maior concentração de população de melhor poder aquisitivo.

Estas estratégias baseiam-se em um modelo ideal de cidade, onde a criação de espaços públicos, o "embelezamento urbano", entre outros, constituem estratégias de marketing urbano, de acordo com o paradigma de Barcelona. As opções de desenho urbano adotadas e a estética desses espaços reforçam seu caráter mercadológico.

Neste capítulo, pretende-se abordar as questões relativas à gestão dos espaços públicos da cidade do Salvador, evidenciando as estratégias diferenciadas do poder público com relação a estes espaços, discutindo-se, em um primeiro momento, suas funções e distribuição no tecido urbano e, depois, ressaltando as diferentes estratégias de apropriação espacial entre bairros ricos e pobres.

\section{UM PRÓLOGO NECESSÁRIO: espaços políticos ou espaços de consumo cultural?}

As questões norteadoras do meu livro "O espaço público na cidade contemporânea" (Serpa, 2007a), podem também servir de mote inicial para este prólogo necessário: Qual é o papel desempenhado pelo espaço público na cidade contemporânea? Que variáveis analisar? E a partir de que teorias e conceitos?

No livro, tal discussão foi encarada como um desafio para a Geografia e para todas as ciências que se pretendam políticas e ativas, já que o espaço público é considerado como o espaço da ação política ou da possibilidade da ação política na contemporaneidade. Esta característica fundamental contrasta, nas cidades contemporâneas, com o processo de incorporação dos espaços públicos urbanos como mercadorias para o consumo, dentro da lógica de produção e reprodução do sistema capitalista na escala mundial. Pois ainda que sejam adjetivados como públicos, poucos se beneficiam desses espaços teoricamente comuns a todos.

Antes de tudo, é necessário discutir o sentido da ação, da ação política, 
que consideramos pertinente para a análise do espaço público no período contemporâneo. Concorda-se aqui com Hannah Arendt, de que a ação é a única atividade que se exerce entre os seres humanos, sem mediação das coisas ou da matéria, correspondendo à "condição humana da pluralidade" (Arendt, 2000, p. 15). Para Arendt, a ação é a atividade política por excelência. Desse modo, razão e vontade, baseadas em princípios universais, estão na base da ação e fundamentam 0 agir político.

Em Habermas (1984), o espaço público, como sinônimo de esfera pública enquanto espaço de mediações, exprime o ideal de uma opinião pública esclarecida, levando a cabo a idéia de uso da "razão como emancipação". Aqui, a utopia iluminista repaginada dá ao espaço público os contornos de uma arena para articulação de consensos, a partir do livre entrechoque de argumentos racionais. Em Habermas, o uso da razão como emancipação deve também se basear em princípios éticos universais, seguindo a tradição kantiana que relaciona moralidade e legalidade, ações políticas e ações morais. Assim, a soberania das leis deve ser conseguida através da publicidade, ou seja, através de um espaço público, cuja capacidade funcional é imposta, sobretudo, com a base natural do estado de direito.

Entretanto, questiona-se: pode-se abordar o espaço público na Salvador contemporânea como o espaço por excelência da ação e do discurso? Como esfera de mediação de iguais na sua diferença, a partir do uso da razão como emancipação?

Essas questões mostram toda sua pertinência, ao verificarmos a (imensa!) dificuldade de muitos pesquisadores no campo das ciências humanas e sociais, quando se trata de relacionar as dimensões políticas e sociais de uma esfera pública urbana e os aspectos formais e estruturais dos espaços públicos "concretos". Dialeticamente, forma e conteúdo são a um só tempo produtos e processos: são auto-condicionantes, auto-referentes e historicamente determinados. Portanto, na análise do espaço público urbano, forma e conteúdo são indissociáveis, e uma discussão sobre essa temática passa necessariamente pela difícil articulação entre os aspectos que dão "concretude" à esfera pública urbana e aqueles de cunho mais abstrato, que denunciam seu caráter intersubjetivo e a necessidade de uma abordagem multifacetada do problema.

Uma abordagem assim passa necessariamente pela discussão da noção de acessibilidade, que está estreitamente vinculada, na demarcação dos territórios urbanos, à alteridade, contrapondo uma dimensão simbólica (e abstrata) à concretude física dos espaços públicos urbanos. Pois, a acessibilidade não é somente física, mas também simbólica, e a apropriação social dos espaços públicos urbanos tem implicações que ultrapassam o design físico de ruas, praças, parques, largos e prédios públicos (Serpa, 2004).

Se for certo que o adjetivo "público" diz respeito a uma acessibilidade generalizada e irrestrita, um espaço acessível a todos deve significar, por outro lado, algo mais do que o simples acesso físico a espaços "abertos" de uso coletivo. Afinal, 
que qualidades norteiam a apropriação social do espaço público na cidade contemporânea? Como explicar a apropriação seletiva e diferenciada de espaços, que, em tese, seriam - ou deveriam ser - acessiveis a todos? (Serpa, 2007a).

Muitos dos "novos" e requalificados espaços públicos urbanos de Salvador permanecem "invisíveis" para a maioria da população, que não dispõe de "capital escolar" (Bourdieu, 1979) para se apropriar das linguagens projetuais e do repertório utilizados no desenho urbano contemporâneo. Pode-se mesmo afirmar que as clivagens sociais ganham aqui status de "segregação social" ou mesmo de exclusão. Tudo isso contribui para a "invisibilidade" desses equipamentos - em contradição com seu "princípio projetual de base", a visibilidade completa e espetacular -, tornando-os exclusivos para o uso de "iniciados". Existe, portanto, uma distância mais social que física, separando os "novos" espaços públicos urbanos daqueles com baixo capital escolar (Serpa, 2004).

Esses espaços surgem a partir da lógica do "consumo cultural" que parece se constituir no novo paradigma para o desenvolvimento urbano na contemporaneidade. As cidades são reinventadas a partir da reutilização das formas do passado, gerando uma urbanidade que se baseia, sobretudo, no consumo e na proliferação (desigual) de equipamentos culturais. Esta nova (velha) cidade folcloriza e industrializa a história e a tradição dos lugares, roubando-lhes a alma. É a cidade das requalificações e revitalizações urbanas, a cidade que busca vantagens comparativas no mercado globalizado das imagens turísticas e dos lugaresespetáculo. A lógica do "consumo cultural" atualiza o já bem conhecido "duplo caráter da centralidade capitalista: lugar de consumo e consumo de lugar" (Lefebvre, 1991, p. 130).

\section{O OUTRO LADO DA MOEDA: a invisibilidade e o abandono das áreas de urbanização popular e de seus espaços públicos}

Na capital baiana, com a "reforma urbana" de 1967, acentua-se o processo de valorização fundiária dos bairros localizados na orla atlântica ou nas suas proximidades em detrimento daqueles situados na orla suburbana e no chamado "miolo". Naquele ano, a prefeitura municipal, grande (e única) proprietária de terrenos localizados às margens da atual Avenida Paralela vende barato seu patrimônio fundiário a (poucas) empreiteiras e construtoras fazendo "explodir" o preço do metro quadrado nessa área da cidade. Surgem novos bairros verticalizados, como o Imbuí. Única via expressa de Salvador, a Avenida Paralela representa, segundo corretores de imóveis, o novo pólo de expansão residencial e comercial da cidade. Bem projetada e com canteiros centrais que possibilitam ainda uma maior ampliação das pistas, a avenida corta áreas remanescentes de Mata Atlântica, o que aumenta seu valor imobiliário. Segundo algumas incorporadoras, o metro quadrado na 
Avenida Paralela já é o mais caro na cidade, considerando-se as dimensões de lotes que são oferecidos, geralmente numa dimensão não inferior a cinco campos de futebol.

Até meados da década de 1970, a cidade abrangia um território equivalente a $30 \%$ da área continental do município. Com a implantação dos parques industriais e das grandes avenidas, a malha urbana é ampliada em mais de três vezes. A intensidade deste crescimento favoreceu a descentralização das atividades e a predominância dos processos informais de criação do espaço urbano. Em 1995, um estudo elaborado pela CONDER (2002) com base em dados do IBGE constatava os seguintes números para o déficit quantitativo de novas moradias no Estado da Bahia: 108.165 na Região Metropolitana de Salvador, 180.999 nas demais áreas urbanas e 209.374 na área rural. 0 mesmo estudo apontava no Estado a existência de 527.058 domicílios carentes de infra-estrutura, 251.385 com infraestrutura inadequada, e mais 176.328 domicílios com adensamento excessivo ou uso de materiais precários na construção. 0 perfil do déficit habitacional no Estado da Bahia indicava a concentração nas famílias com renda até dois salários mínimos, que correspondiam a $70,90 \%$ do déficit.

A partir de 1995, o Programa Viver Melhor vem ao encontro desse déficit, levando melhorias habitacionais a bairros periféricos e carentes, com a construção, em alguns casos, de novas unidades habitacionais. A lógica do programa, no entanto, permanece fiel à idéia de fixar a população de baixa renda em áreas sem amenidades físicas e distantes das áreas centrais e turísticas da cidade, como no Projeto Cajazeiras - constituído de cooperativas habitacionais populares, implantadas ao longo dos anos 1970-1980 na periferia da cidade pela URBIS Habitação e Urbanização da Bahia S/A -, com o objetivo de instituir um subcentro regional (de equipamentos, comércio e serviços), que contribuísse para evitar a hipertrofia da área central.

As áreas de urbanização popular resultam em sua maior parte do esforço e do trabalho dos moradores, já que são deficientes as políticas habitacionais para a população de baixa renda na cidade e no país. O bairro de Cajazeiras, no miolo da cidade, é um exemplo de conjunto habitacional popular, caracterizado por edificações com baixo padrão construtivo e precariedade arquitetônica e urbanística. Como nesse bairro, hoje, as áreas de urbanização popular em Salvador caracterizamse por uma mistura de habitações auto-construídas e conjuntos habitacionais edificados por iniciativa da prefeitura e do Estado, freqüentemente afastados das áreas centrais, o que implica em altos custos de transporte para seus habitantes. Por outro lado, os bairros populares mais antigos, localizados na orla da Baía de Todos os Santos, atraem também setores médios da população, que usufruem de alguma infra-estrutura e preços mais vantajosos nas áreas mais consolidadas. Muitos trabalham na indústria, na construção civil ou no setor de comércio e serviços, alguns até no serviço público (Serpa, 2007b).

Os Programas de requalificação dos espaços públicos urbanos em 
Salvador, mencionados no início deste capítulo, não atendem, via de regra, as áreas de urbanização popular da cidade, onde 0 abandono e a invisibilidade de parques e praças são notórios. É este exatamente o caso do Parque de São Bartolomeu, localizado no Subúrbio Ferroviário, um remanescente de Mata Atlântica que abriga a nascente do Rio do Cobre, considerado espaço sagrado para os praticantes do Candomblé (Serpa, 1996; 1998). O estado de abandono, os assaltos freqüentes, 0 descaso e a ausência de políticas públicas para o parque inviabilizam os ritos do Candomblé, afastando seus praticantes do local. Contudo, o Subúrbio Ferroviário inteiro poderia ter sido beneficiado com o Parque, caso o equipamento tivesse sido requalificado para a população desta área da cidade. Seus moradores não precisariam atravessar a cidade para ter acesso a uma área pública de lazer, já que há uma evidente concentração de espaços públicos nas áreas mais centrais e valorizadas da cidade, como as regiões administrativas Centro, Barra, Pituba, Boca do Rio e Itapuã, como mostra a Tabela a seguir.

Em Salvador, das três milhões e 691 mil viagens feitas diariamente pelos habitantes da cidade, um milhão e 70 mil são feitas a pé, de acordo com uma pesquisa da Superintendência de Transportes Públicos, da Prefeitura Municipal. As causas apontadas pelo estudo - que contemplou 600 mil domicílios - para este fato são, além das dificuldades financeiras (a principal), as necessidades de deslocamentos curtos, a deficiência do sistema de transportes e a tradição das

Tabela 1 - Distribuição de Parques, Praças e Largos por Região Administrativa - Salvador - Novembro de 2000

\begin{tabular}{|c|c|c|c|c|c|}
\hline Região Administrativa & $\begin{array}{l}\text { População } \\
\text { n. de Hab. }\end{array}$ & $\begin{array}{l}\text { Parques } \\
\text { Unid./ m2 }\end{array}$ & $\begin{array}{c}\text { Praças } \\
\text { Unid./ m2 }\end{array}$ & $\begin{array}{l}\text { Largos } \\
\text { Unid./ m2 }\end{array}$ & $\begin{array}{l}\text { Área Total } \\
(\mathrm{m} 2)\end{array}$ \\
\hline I - Centro & 80.174 & 1/ 110.000 & $39 / 130.701,14$ & $23 / 39.546,91$ & $280.248,05$ \\
\hline II - Itapagipe & 146.736 & - & $25 / 42.805,84$ & $13 / 50.143,10$ & $92.948,94$ \\
\hline III - S. Caetano & 207.914 & - & $6 / 3.400,80$ & $3 / 782,57$ & $4.183,37$ \\
\hline IV - Liberdade & 176.757 & - & $13 / 2.029,20$ & $4 / 8.088,50$ & $10.117,70$ \\
\hline V - Brotas & 185.550 & - & $6 / 5.468,11$ & $3 / 1.469,53$ & $6.937,64$ \\
\hline VI - Barra & 66.143 & $1 / 250.000$ & $5 / 8.464,30$ & $5 / 1.583,20$ & $260.047,50$ \\
\hline VII - Rio Vermelho & 167.809 & - & $15 / 32.533,64$ & $7 / 13.712,35$ & $46.245,99$ \\
\hline VIII - Pituba & 73.819 & $2 / 800.000$ & $17 / 72.755,20$ & - & $872.755,20$ \\
\hline IX - Boca do Rio & 100.610 & $3 / 4.657 .600$ & 9/ 16.802,27 & - & $4.674 .402,27$ \\
\hline X - Itapuã & 176.776 & 2/ 2.550 .000 & $17 / 122.598,88$ & 4/ $12.557,70$ & $2.685 .156,58$ \\
\hline XI - Cabula & 130.122 & - & 2/ $1.424,80$ & 2/ $1.591,10$ & $3.015,90$ \\
\hline XII - Tancredo Neves & 178.803 & - & $5 / 5.778,00$ & - & $5.778,00$ \\
\hline XIII - Pau da Lima & 179.639 & - & $10 / 8.927,40$ & - & $8.927,40$ \\
\hline XIV - Cajazeiras & 124.922 & - & $1 / 4.180,00$ & $1 / 366,30$ & $4.546,30$ \\
\hline XV - Valéria & 61.909 & 1/ 750.000 & - & 1/ $1.025,00$ & $751.025,00$ \\
\hline XVI - Subúrbio Ferroviário & 241.741 & - & $6 / 8.816,80$ & $2 / 315,00$ & $9.131,80$ \\
\hline XVII - Ihas & 2.287 & 2/ 340.000 & - & - & 340.000 \\
\hline Total & 2.301 .711 & $12 / 9.457 .600$ & $176 / 466.686,38$ & $68 / 131.181,26$ & $10.055 .467,64$ \\
\hline
\end{tabular}

Fonte: Estudo de Lazer - PDDU Salvador, 2002. 
caminhadas em festas populares. Apenas $21 \%$ dos domicílios pesquisados têm um carro estacionado na garagem (Rocha, 1998). Deste modo, ao priorizar a implantação de novos parques e praças na orla atlântica de Salvador, em detrimento da orla suburbana - onde a renda média da população é de um a três salários mínimos - o governo e a prefeitura acabam discriminando grande parte da população soteropolitana, justamente aquela com mais dificuldades de deslocamento e falta de opções de lazer.

Uma simples comparação a partir dos dados contidos na Tabela 1 mostra um desequilíbrio evidente entre 0 número de praças existentes nas regiões administrativas I, V, VI, VII, VIII, IX, X, com predominância de população de maior poder aquisitivo, e as Regiões administrativas II, III, IV, XII, XII, XIII, XIV, XV, XVI, XVII, de perfil mais popular e com população de baixa renda: são 108 contra 68. No que tange aos parques públicos a lógica é exatamente a mesma, com a concentração desses equipamentos em áreas com infra-estrutura consolidada e população com maior renda e escolaridade, como pode ser visualizado no Mapa 1.

Em Salvador, pesquisa realizada por Brito (1997) mostra que as Regiões administrativas XVI (Subúrbio Ferroviário) e XIV (Cajazeiras) dividem o metro quadrado mais barato da cidade, em contraste com as Regiões administrativas mais centrais e/ou localizadas na orla atlântica, como Barra, Rio Vermelho, Pituba, Boca do Rio e Itapuã. Como não há estudos sistemáticos e detalhados sobre o preço do metro quadrado na capital baiana, o autor acompanhou durante os anos de 1970, 1980, 1990 e 1996 a publicação de anúncios classificados de vendas de terrenos, casas e apartamentos em Salvador, no jornal A Tarde, para escrever sua dissertação de mestrado sobre a escassez de terrenos para construção na capital baiana (Brito, 1997).

A cidade, que cresceu de sul para norte, se desenvolveu inicialmente a partir da entrada da Baía de Todos os Santos ao longo de sua borda leste. A análise da dinâmica de sua expansão urbana permite individualizar dois vetores principais de crescimento. Um primeiro vetor, ao longo da BR-324, engloba uma mancha urbana de baixa renda, que pressiona os ambientes estuarinos da Baía de Todos os Santos. O segundo vetor se desenvolve ao longo da Avenida Paralela, englobando uma mancha urbana de renda média alta, compreendida entre esta via e a orla atlântica. Enquanto na orla atlântica investimentos em infra-estrutura estão na ordem do dia, nas praias da Baía a situação é de abandono e degradação. Embora o Programa de Recuperação das Áreas Degradadas de Salvador e dos Parques Metropolitanos seja uma tentativa de repensar a cidade em termos urbanísticos, 0 que vem sendo priorizado pela CONDER é a vocação turística da capital baiana, com a valorização de grandes parques, próximos à orla atlântica.

Os novos parques da orla atlântica vêm, portanto, alimentar e "coroar" um processo de valorização imobiliária das áreas nobres da cidade, acrescentando novas amenidades físicas aos bairros que já possuem melhor infra-estrutura de comércio e serviços, bem como vias expressas para circulação de veículos 
Mapa 1 - Sistema de parques públicos - Salvador 2006

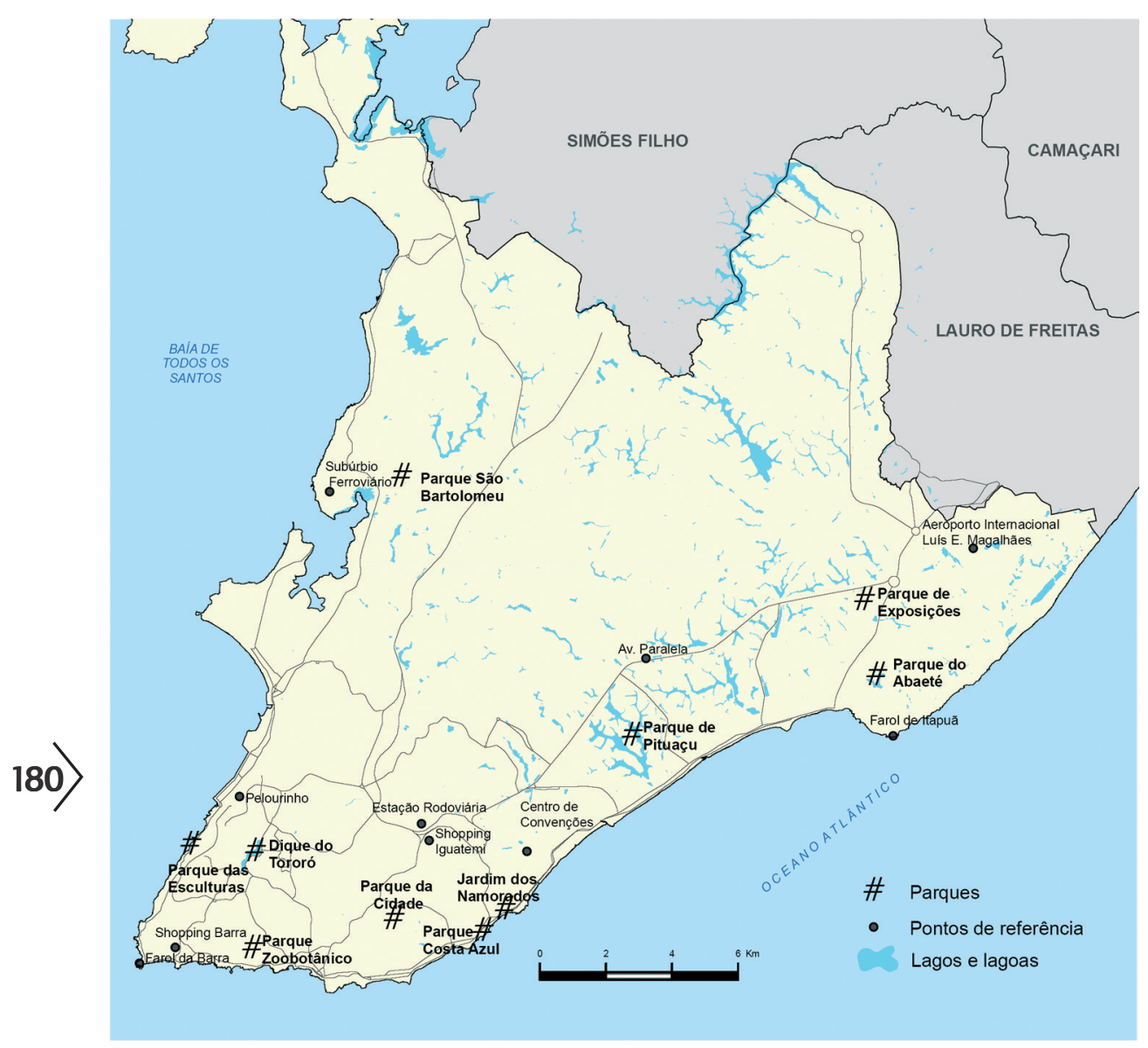

Fonte: Base Cartográfica 1992 - Conder. Elaboração Ana Rosa Iberti e Angelo Serpa

particulares. A lógica da localização dos parques em Salvador obedece também ao princípio de priorizar áreas com algum interesse turístico, próximas a grandes equipamentos como o Aeroporto Internacional, o Centro de Convenções e os shoppings centers Iguatemi e Aeroclube Plaza.

Esta é também a lógica que norteia a adoção de praças, parques e outros espaços livres de edificação por empresas privadas, no contexto de um programa desenvolvido desde 1997 pela Prefeitura Municipal de Salvador, o Programa de Adoção de Praças, Áreas Verdes, Monumentos e Espaços Livres. Uma análise dos espaços "adotados" pela iniciativa privada através desse programa corrobora mais uma vez a tese do desinteresse por praças e parques localizados em áreas de urbanização popular da cidade. A adoção concentra-se nas Regiões administrativas com população de maior poder aquisitivo e escolaridade, como é o caso das Praças 
Mapa 2 - Valor médio dos terrenos em US\$/m² por Região Administrativa - Salvador 1996

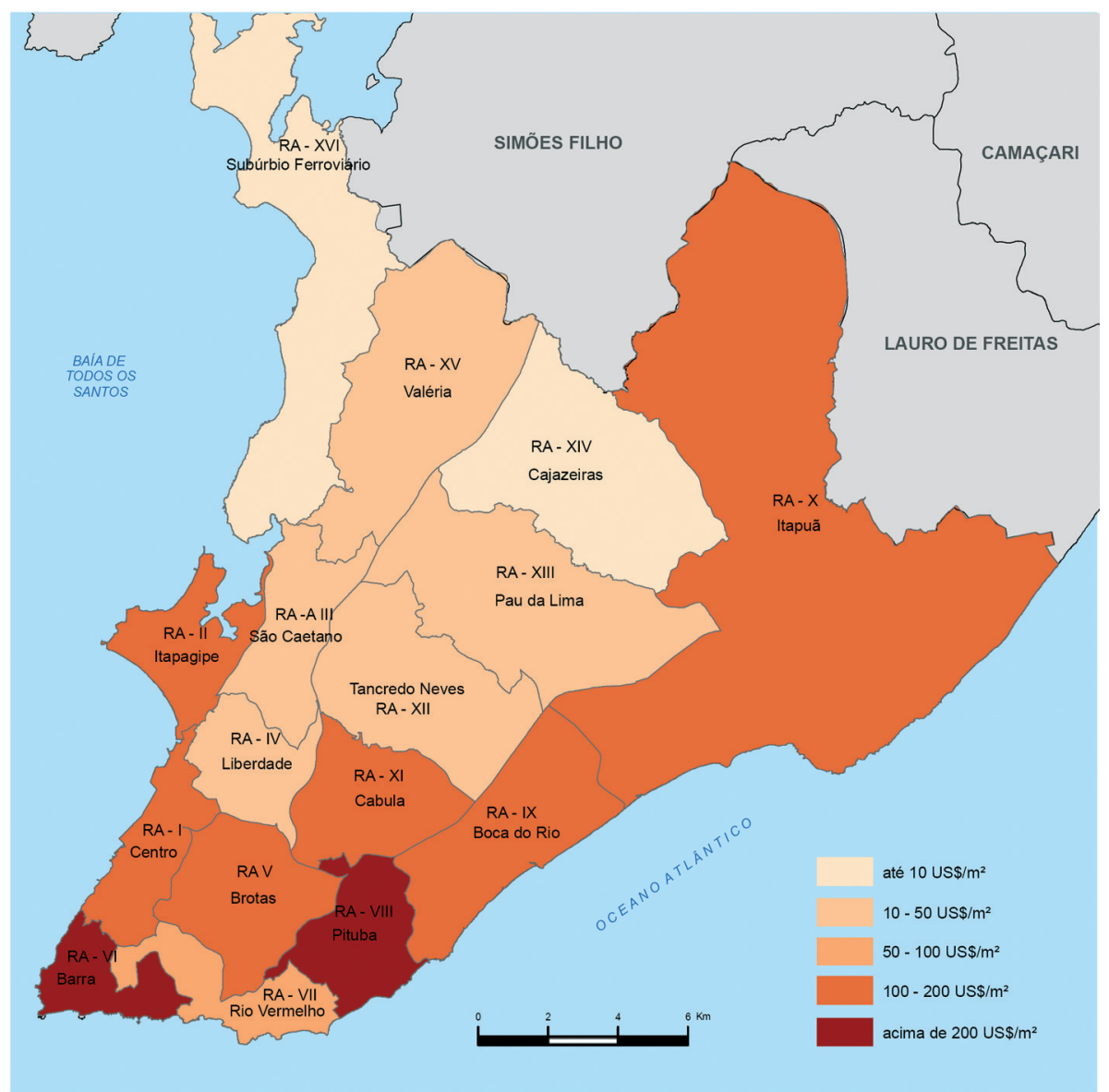

Fonte: Elaborado por Cristovão Brito; com base em classificados do jornal A Tarde de 1996. Reelaborado por Ana Rosa Iberti e Angelo Serpa

Marconi e Nossa Senhora da Luz (ambas localizadas no bairro da Pituba), a Praça do Iguatemi, o Parque da Cidade (localizado no bairro do Itaigara) e a Avenida Antônio Carlos Magalhães (Serpa, 2003). Os espaços adotados acabam funcionando como grandes outdoors tridimensionais, como estratégia de publicidade das empresas "adotantes", que não se interessam por praças, avenidas e parques localizados em áreas de perfil popular e com concentração de população de baixa renda, destacadas no Mapa 3.

Por meio do Programa "Adote uma Praça" a iniciativa privada pode manter os espaços públicos e, em contrapartida, placas com o nome das empresas adotantes são colocadas nas praças, parques ou avenidas adotados. Até hoje, desde a implantação do programa, são 90 contratos assinados com a Prefeitura. 0 prazo de adoção é de dois anos, podendo os contratos serem prorrogados. As empresas 
Mapa 3 - Responsáveis por domicílios sem rendimento ou com renda até 2SM por setor censitário Salvador - 2000

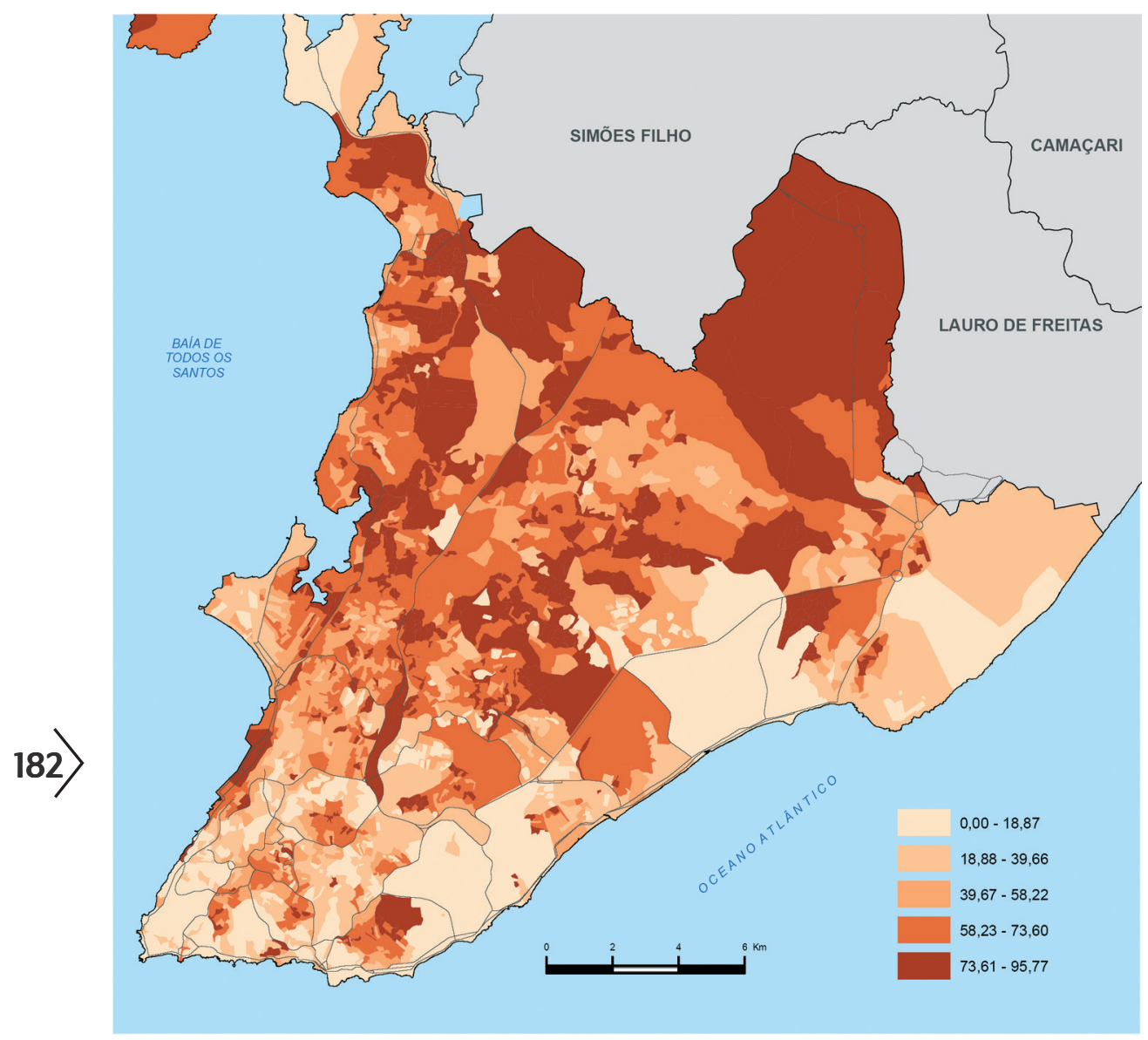

Fonte: CONDER/IBGE, Censo Demográfico, 2000. Base cartográfica SICAR/RMS, 1992. Mapa elaborado pelo autor.

adotantes não precisam ter gastos contínuos, podendo optar por recuperar os espaços e deixar sua manutenção por conta da Prefeitura. Durante o processo de adoção, a Prefeitura se encarrega de elaborar um projeto de recuperação e 0 encaminha à empresa interessada. É a Superintendência de Parques e Jardins quem fiscaliza o cumprimento dos contratos pelas instituições adotantes. 0 Programa não é inédito no país e já existe em outras cidades do Rio Grande do Sul, Minas Gerais e Pernambuco (A Tarde, 25/6/2006).

Na capital baiana, a Região da Pituba é a preferida para adoção de praças. No final de linha do Itaigara, por exemplo, uma rede de supermercados investiu um milhão de reais na construção da Praça Ana Luísa Magalhães. A Superintendência de Parques e Jardins admite que as empresas preferem adotar espaços naqueles bairros ou regiões onde se encontram seus maiores 
estabelecimentos, em detrimento dos bairros ou regiões com população de baixa renda e pouca densidade de estabelecimentos comerciais e de serviços. 0 resultado é que várias praças continuam a espera de adoção, como a Praça dos Dendezeiros, no bairro do Bonfim, e as Praças Wilson do Carmo Pires e Joanes Leste, no bairro do Lobato, localizado no Subúrbio Ferroviário (A Tarde, 25/6/2006).

\section{AS CLASSES MÉDIAS VÃO AO PARAÍSO... MAS EVITAM OS ESPAÇOS PÚBLICOS URBANOS}

Minhas pesquisas mostram que a concepção e implantação de novos espaços públicos (parques e grandes praças) em Salvador, a partir dos anos 1990, estiveram sempre subordinadas a diretrizes econômicas, políticas e ideológicas. $\mathrm{Na}$ Salvador contemporânea, como em outras metrópoles do mundo ocidental, os espaços públicos urbanos são meios de controle social, sobretudo das novas classes médias, destino final das políticas públicas, que, em última instância, procuram multiplicar o consumo e valorizar o solo urbano nos locais onde são aplicadas.

Mais precisamente, as novas classes médias são representadas pelos novos grupos de trabalhadores qualificados, engenheiros e técnicos, que surgem em função da evolução das condições de produção, pelas classes médias assalariadas com um nível elevado de estudos, pelas novas (ou renovadas) categorias profissionais, ou, simplesmente, pelo setor terciário inteiro, salvo evidentemente o "novo proletariado" terciário, constituído por categorias de trabalhadores pouco qualificados, mal remunerados e/ ou com empregos precários. Trata-se de posições sócio-econômicas equivalentes, onde as relações e representações estão "socialmente referenciadas". Pensa-se aqui no conceito de "habitus", naquilo que concerne aos comportamentos das classes médias ao se apropriarem do espaço público contemporâneo (Bourdieu, 1979; Serpa, 2007a).

O consumo e o lazer das novas classes médias são, afinal, os "motores" de complexas transformações urbanas, modificando áreas residenciais e comerciais decadentes, recuperando e "integrando" waterfronts, desenvolvendo novas atividades de comércio e de lazer "festivo". Os exemplos se sucedem em Salvador: o Parque Costa Azul foi implantado no lugar de um antigo hotel em ruínas, margeando a orla atlântica, enquanto 0 Jardim dos Namorados foi projetado para dar origem a uma zona de pedestres e ciclistas na beira do mar. A implantação dos parques na década de 1990 na capital baiana foi iniciada com a inauguração do Parque do Abaeté. $O$ exemplo do Parque do Abaeté é emblemático para demonstrar a uniformização visual e funcional dos espaços públicos urbanos, onde os parques se assemelham cada vez mais aos shopping-centers, com a valorização do consumo como atividade de lazer. Restaurantes e bares parecem ser a principal atração do lugar para os moradores da cidade, embora a lagoa continue a atrair turistas de procedências diversas (Serpa, 2001; 2007a). 
Com relação às praças, que em geral não oferecem as opções de lazer encontradas nos parques públicos (shows musicais, feiras de artesanato, restaurantes, áreas esportivas e de lazer infantil, entre outras), pode-se dizer que são ainda menos utilizadas que os parques, principalmente nas áreas nobres da cidade. Mesmo assim, praças continuam a ser adotadas por empresas nessas áreas e outras novas são criadas, muitas vezes para valorizar o solo urbano ou para promover a "limpeza" desses locais de usos e usuários indesejáveis, como é o caso da Praça Catarina Paraguaçu, localizada no bairro da Graça, um dos redutos da classe média alta soteropolitana. A Praça foi inaugurada em 2007, com áreas de estar e de lazer infantil, mas é difícil encontrar alguém que se aproprie dos equipamentos disponibilizados. Com a implantação da Praça, foram expulsos dali seus antigos usuários, lavadores de carro que trabalhavam no local, usufruindo da água de uma fonte ali existente.

Parques e praças sofrem com a concorrência dos shopping-centers, vistos atualmente pelos estratos médios da população soteropolitana como uma forma "segura" de lazer e consumo frente à "insegurança" dos espaços públicos urbanos, que passam a ser evitados até mesmo pelas classes populares. Yázigi (2000) lembra que o primeiro shopping brasileiro - o Iguatemi - foi inaugurado em 1966 na cidade de São Paulo. Mas é nos anos 1980 que eles vão se estabelecer definitivamente nas cidades brasileiras - inclusive em muitas cidades médias representando a realização de um modelo norte-americano de comodidade e status social. Para o autor, os primeiros shoppings no Brasil não eram ainda uma resposta à violência urbana, mas talvez já denunciassem "a clarividência de seus empreendedores sobre um futuro próximo e sombrio" (Yázigi, 2000, p. 254). A segregação do consumo resultaria, sob essa ótica, da incapacidade da sociedade brasileira em equacionar o fosso entre as classes sociais, que levaria a "situações de perda para o espaço público" (Yázigi, op. cit., p. 257). Assim, os shoppings tornamse redutos de pessoas de diferentes estratos médios, particularmente em finais de semana, onde há "encontros, paqueras, 'derivas', ócio, exibição, tédio, passeio, consumo simbólico" (Yázigi, op. cit., p. 258)

É preciso, pois, admitir a possibilidade de encontros de naturezas diversas nos shoppings centers, entendendo-os também como espaços urbanos de sociabilidade, embora isso pareça à primeira vista algo contraditório, já que, na sua origem, esses equipamentos baseiam-se, como princípio de concepção, na segmentação e no controle da acessibilidade. Lugar específico de determinados grupos, o shopping aparece como local preferido para o passear a pé para jovens mulheres e representantes da denominada "classe C", mas também é o lugar da galera, ${ }^{1}$ dos jovens namorados, dos pais com os filhos, etc.

\footnotetext{
${ }^{1}$ Baseando-se em um estudo de Armando Silva (1992), que aponta uma preferência da ordem de 78,9\% entre os jovens paulistanos - sem distinções de classe social - por centros comerciais como locais de encontro, Yázigi (op. cit.) vai mais longe, vislumbrando o futuro dos shoppings como lugares da cultura urbana.
} 


\section{CONCLUSÃO}

Os exemplos analisados neste capítulo mostram que a crise da modernidade é uma crise nos domínios público e privado: A erosão do equilíbrio entre a vida pública e a vida privada destrói o pilar que sustentava a sociedade nos primórdios do capitalismo (Sennet, 1998). Caminhamos para a consagração do individualismo como modo de vida ideal, em detrimento de espaços públicos cada vez mais decadentes.

Nossas relações de vizinhança são condicionadas de uma forma determinante pela densidade populacional do local que habitamos, pelo nível econômico e pelo grau de cooperação dos seus habitantes, bem como pela distância entre as unidades de habitação (Keller, 1979). As relações de vizinhança na Salvador contemporânea são também ainda muito condicionadas pelas diferenças entre classes sociais. Nos bairros populares, a limitação de oportunidades, a pobreza e o isolamento relativos, a insegurança e o medo acabam por fortalecê-las e torná-las parte fundamental da trama de relações familiares. Nos bairros de classe média, as relações entre vizinhos são mais seletivas e pessoais, já que o maior poder aquisitivo faz diminuir a necessidade de ajuda mútua e aumentar a necessidade individual de espaço.

Sofrem as metrópoles contemporâneas, especialmente no Brasil, com a fragmentação do tecido sócio-político espacial e a formação de enclaves territoriais no tecido urbano, sofisticando as formas de auto-segregação dos habitantes. Esses enclaves formam, nos bairros com urbanização de status, circuitos exclusivos, cada vez mais restritos, de residências (condomínios), lazer (parques temáticos) e consumo (shopping centers), constituindo o processo que Souza (2001) denomina de "involução metropolitana". Se é evidente a polarização social e espacial na cidade, por outro lado, e mais recentemente, processos de fragmentação também estão em curso na capital baiana. Se, antes, a segregação espacial era mais facilmente identificável no espaço soteropolitano, hoje há também, e isso em todos os municípios da região metropolitana, áreas de urbanização popular convivendo lado a lado com condomínios de classe média. Como para outras metrópoles do país, também para a aglomeração soteropolitana, a fase de concentração da população no município-sede vem sendo paulatinamente substituída por um processo generalizado de suburbanização, visivel no crescimento acelerado dos municípios mais próximos de Salvador e localizados na RMS, como é o caso de Lauro de Freitas (Serpa, 2007b).

Se nos bairros populares da cidade contemporânea falta espaço para intervenções paisagísticas e urbanísticas "de monta", é necessário afinar o olhar para o sistema de ações que se operacionaliza sobre um sistema de objetos (Santos, 1996), aparentemente inadequado para o lazer e as manifestações culturais e festivas de seus moradores. É necessário abandonar a perspectiva tradicional que no fundo desejaria o extermínio de paisagens classificadas a priori como "não-cidadãs" ou, sob essa mesma ótica, como paisagens sem "qualidade ambiental". É necessário 
se ocupar dos espaços ocultos e residuais, das "lajes" de uma paisagem que "espontaneamente" se verticaliza, dos interstícios das construções, dos "restos" de espaços dos becos e vielas, onde a população dos bairros populares compartilha seus encontros, seu lazer e sua diversão (Serpa, 2007c).

Para a Geografia e também para o Planejamento resta a reflexão de como se debruçar sobre estes espaços urbanos residuais e intersticiais, sobre as "sobras" e "restos" de cidade, não "aproveitados" pelas estratégias dos agentes hegemônicos de produção do espaço. Isso coloca para ambas as áreas do conhecimento uma agenda de pesquisa que busque qualificar os encontros e as trocas na cidade contemporânea, se debruçando sobre a densidade de ocorrência das manifestações culturais nos espaços livres de edificação/urbanização, refletindo sobre a adequação entre formas e conteúdos urbanos. É necessário qualificar nossas análises e nossos levantamentos, dando visibilidade àquilo que está oculto para a produção e o consumo cultural de massa. Trata-se de explicitar as manifestações da cultura popular em nossa cidade e suas formas de organização, resgatando 0 sentido lúdico e a ludicidade do urbano no período contemporâneo (Serpa, 2007c). Mesmo com déficits evidentes de infra-estrutura, com o quadro generalizado de pobreza, desemprego e problemas ambientais, os bairros populares da metrópole são centrais para a diversidade social e cultural no espaço metropolitano. E isso acontece apesar da concentração dos espaços públicos e equipamentos culturais nos bairros de classe média em Salvador e nos demais municípios da Região Metropolitana. Importante observar nesse contexto que não se trata de modo algum de uma idéia hegemônica de cultura, de uma idéia de "cultura erudita", mas, ao contrário, de idéias de cultura alternativas à cultura dominante, que se manifestam no dia-a-dia das áreas de urbanização popular da metrópole (Serpa, 2007d).

É necessário reconhecer a existência de culturas dominantes e subdominantes ou "alternativas", não apenas no sentido político, como também, em termos de sexo, idade e etnicidade, já que o poder é expresso e mantido através da reprodução da cultura (Cosgrove, 1998). Nos bairros populares da cidade, muitas vezes à margem de qualquer subsídio ou lei de apoio à cultura, manifestações populares "alternativas" vão surgindo ou "teimosamente" persistindo. São manifestações "esquecidas" pela mídia e pelo marketing turístico, como a capoeira, as rendeiras, a costura artesanal, as festas de pescadores, os grupos de teatro popular, as festas promovidas pelas associações de moradores, os autos de natal, os corais, os carnavais de bairro, o maculelê, os blocos e as danças afro. Na maioria das vezes, é no espaço das associações de moradores, das paróquias e dos terreiros de candomblé, que essas manifestações encontram algum espaço de expressão. Ao mesmo tempo, muitas delas vão desaparecendo, permanecendo vivas apenas na memória de alguns moradores.

Se levarmos a sério a idéia de "cultura popular", então seria necessário também questionar a inadequação dos espaços públicos urbanos e a política que 
norteia sua implantação e gestão na metrópole soteropolitana. De modo paradoxal, as áreas de urbanização popular das periferias metropolitanas transformam-se em centros de cultura urbana em Salvador, no "coração" de diferentes manifestações da cultura afro-brasileira, como os blocos afro llê Aiyê e Araketu, por exemplo. Como local de nascimento de muitos artistas, que encontram grande sucesso na indústria cultural do país, as áreas de urbanização popular das periferias soteropolitanas desempenham um papel central na maior festa de rua do planeta: o Carnaval de Salvador (Serpa, 2007b).

Espaços públicos urbanos esvaziados nos bairros de classe média e abandonados ou inexistentes nas áreas de urbanização popular comprovam a disseminação também em Salvador de um estilo de vida que exclui a possibilidade do encontro e da emergência de uma esfera pública como espaço de expressão das sociabilidades urbanas e da mediação dos conflitos. Quando apropriados, esses espaços revelam-se como uma justaposição de territórios privatizados, onde não há nem encontros nem um espaço compartilhado por seres humanos iguais em sua diferença, mas, sobretudo, um espaço dividido entre os diferentes grupos de usuários. Conseqüentemente, a acessibilidade não é mais generalizada, mas limitada e controlada simbolicamente.

Falta interação entre esses territórios, percebidos (e utilizados) como uma maneira de neutralizar o "outro" em um espaço que é acessivel a todos. Os usuários do espaço contribuem assim para a amplificação da esfera privada no espaço público, fazendo emergir uma sorte de estranhamento mútuo de territórios privados, expostos, no entanto, a uma visibilidade completa. Também na Salvador contemporânea, toda cultura da exposição pública é ao mesmo tempo uma cultura do desengajamento, pois o espaço público "neutraliza-se" do interior, através da percepção simultânea e constante das diferenças (Joseph, 1998).

Isso significa também, retomando as idéias de Arendt e Habermas, que, no espaço público soteropolitano, o comportamento e a norma substituem e, em alguns casos, eliminam totalmente a ação e a espontaneidade. $O$ que resta são espaços de uso coletivo (quando de fato usados), esvaziados de sua dimensão lúdica e política, transformados em mercadorias, em tempos de consumo cultural e de requalificação urbana.

\section{REFERENCIAS}

ARENDT, H. A Condição Humana, 10. Ed. Rio de Janeiro: Forense Universitária, 2000.

BOURDIEU, P. La distinction - Critique sociale du jugement. Paris: Les Éditions de Minuit, 1979.

BRITO, C. C. da T. A produção da escassez de terrenos urbanos em Salvador e suas conseqüências na reprodução futura do espaço urbano. 1997. 131 f. Dissertação (Mestrado em Geografia) - Instituto de Geociências, Universidade Federal da Bahia, Salvador, 1997.

CONDER - Companhia de Desenvolvimento Urbano do Estado da Bahia. Programa Viver Melhor. Disponível em: www.conder.ba.gov.br/prog_viver.htm. Acesso em: 3 de dezembro de 2002. 
COSGROVE, D. A Geografia está em toda parte: Cultura e Simbolismo nas paisagens Humanas. In: Roberto Lobato Corrêa; Zeny Rosendahl (Orgs.). Paisagem, tempo e cultura. Rio de Janeiro: EDUERJ, 1998, p. 92-122.

EMELIANOFF, C. Les villes européennes face au développement durable: une floraison d'initiatives sur fond de désengagement politique. Cahiers du PROSES, n. 8, Sciences-Po, 2004.

HABERMAS, J. Mudança estrutural da esfera pública. Rio de Janeiro: Tempo Brasileiro, 1984.

JOSEPH, I. La Ville sans Qualités. La Tour d'Aigues: Éditions de l'Aube, 1998.

KELLER, S. El vecindário urbano: una perspectiva sociológica. 2. ed. México: Siglo XXI ed., 1979.

LEFEBVRE, H. O direito à cidade. São Paulo: Editora Moraes, 1991.

PRAÇAS esquecidas na cidade. Jornal A Tarde, 1. Caderno, 25/6/2006, p. 6.

ROCHA, F. U. S. Nem só quem tem fé vai a pé: subsídios a uma politica para o pedestre em Salvador. Salvador, 1998. 74 f. Monografia (Especialização) - Escola de Serviço Público, FUNDESP, Universidade Estadual de Feira de Santana, Feira de Santana-BA, 1998.

SANTOS, M. A natureza do espaço: técnica e tempo, razão e emoção. 2. ed. São Paulo: HUCITEC, 1996. SENNET, R. O declínio do homem público. 6. reimpressão. São Paulo: Companhia das Letras, 1998.

SERPA, A. Ponto convergente de utopias e culturas: o Parque de São Bartolomeu. Revista Tempo Social, São Paulo, v. 8, n. 2, p. 177-190, 1996.

SERPA, A. Fatores Sócio-Culturais na Avaliação de Impactos Ambientais: O Caso da Periferia de Salvador. Cadernos do Expogeo, Salvador-BA, v. 9, n. 9, p. 23-33, 1998.

SERPA, A. Parque do Abaeté e Parque das Esculturas em Salvador: Uma análise comparativa. In: Alina Gonçalves Santiago (Org.). Tendências da Paisagem Contemporânea. 1. ed. Florianópolis: Imprensa Universitária/Universidade Federal de Santa Catarina, 2001, p. 222-230.

SERPA, A. Apropriação social versus requalificação dos parques e praças na capital baiana. In: Milton Esteves Júnior; Urpy Montoya Uriarte (Orgs.). Panoramas Urbanos: reflexões sobre a cidade. 1. ed. Salvador-BA: EDUFBA, 2003, p. 121-139.

SERPA, A. Espaço Público e Acessibilidade: Notas para uma abordagem geográfica. Geousp, São Paulo - SP, v. 15, n. 15, p. 21-37, 2004.

SERPA, A. Gestão Territorial do Sistema de Parques Públicos em Salvador, Bahia: Contradições e Paradoxos. RA'EGA (UFPR), Curitiba-PR, v. 12, p. 9-19, 2006.

SERPA, A. O espaço público na cidade contemporânea. 1. ed. São Paulo: Editora Contexto, 2007a. 208 p.

SERPA, A. Periferização e metropolização no Brasil e na Bahia: 0 exemplo de Salvador. Geotextos (UFBA), Salvador-BA, v. 3, p. 31-46, $2007 \mathrm{~b}$.

SERPA, A. A Cidade e o Urbano: Discutindo o Conceito de "Centralidades Lúdicas". Espaço e geografia (UnB), Brasilia-DF, v. 10, p. 271-284, 2007c.

SERPA, A. (Org.). Cidade Popular - trama de relações sócio-espaciais. 1. ed. Salvador: Editora da Universidade Federal da Bahia - EDUFBA, 2007d.

SOUZA, M. J. L. de. Da "fragmentação do tecido sóciopolítico-espacial" da metrópole à "desmetropolização relativa": alguns aspectos da urbanização brasileira nas décadas de 80 e 90. In: Maria Encarnação Beltrão Sposito (Org.). Urbanização e cidades: perspectivas geográficas. Presidente Prudente: UNESP/GAsPERR, 2001. p. 391-417.

YÁZIGI, E. O mundo das calçadas. São Paulo: Humanitas/FFLCH-USP; Imprensa Oficial do Estado, 2000. 


\section{METROPOLIZAÇÅO E TURISMO NO LITORAL NORTE DE SALVADOR: DE UM DESERTO A UM TERRITÓRIO DE ENCLAVES?}

Sylvio Bandeira de Mello e Silva* Barbara-Christine Nentwig Silva** Silvana Sá de Carvalho**

O propósito deste trabalho é o de analisar as transformações recentes e em curso no litoral ao Norte de Salvador, destacadamente provocadas pela rápida expansão das atividades de turismo, recreação e lazer, discutindo suas características, seus problemas e suas perspectivas no contexto metropolitano. Assim, duas questões bastante integradas emergem de forma prioritária: a questão metropolitana e a questão do turismo.

\section{METROPOLIZAÇÃO E TURISMO: questões gerais}

A metropolização, em seus diversos níveis, inclusive com a formação de megalópoles mundiais, é um fenômeno de grande expressão em nossos dias já que promove, sob a forma de redes, a complexa articulação inter-setorial de questões econômicas, sociais, políticas e culturais em uma perspectiva inter-escalar, do local ao global. As regiões metropolitanas podem ser definidas como extensas áreas

* Professor do Programa de Pós-graduação em Planejamento Territorial e Desenvolvimento Social/UCSAL e do Mestrado em Geografia/UFBA.Pesquisador CNPq.

"Professora do Programa de Pós-graduação em Planejamento Territorial e Desenvolvimento Social/UCSAL e do Mestrado em Geografia/UFBA.Pesquisadora/CNPq.

*** Dra. em Geografia, Bolsista de Pós-Doutorado/FAPESB/ Programa de Pós-graduação em Planejamento Territorial e Desenvolvimento Social/UCSAL.

Os autores agradecem a colaboração de Maina Pirajá Silva, Bolsista de Iniciação Científica/CNPq. 
urbanas, comandadas normalmente por uma grande cidade, que apresentam forte diversidade e interdependência funcional e altas densidades demográficas e econômicas. Tal fenômeno sócio-espacial ganhou ainda maior impulso, nas últimas décadas, com o processo de globalização, ou seja, com o acelerado incremento das relações econômicas, sociais, políticas e culturais, inclusive intensamente mantidas em tempo real. A metropolização expressa o fato de que as forças de concentração espacial são muito poderosas, tanto nos principais centros da economia mundial, como, bem mais recentemente e rapidamente, nos países menos desenvolvidos. Nestes últimos, a metropolização, em termos gerais, tem sido uma decorrência da combinação da crescente intensidade dos processos de expulsão do campo e de pequenos e até, eventualmente, de médios centros com o crescimento das forças econômicas de atração metropolitana no contexto nacional e internacional. Estes mecanismos são ligados, em resumo, ao papel das economias externas de aglomeração com suas abrangentes repercussões e desdobramentos, ou seja, aos ganhos resultantes da redução dos custos de produção, distribuição e de transação decorrentes da concentração produtiva e de consumo.

A pergunta que se coloca é a de saber se há também forças contrárias à exagerada concentração metropolitana. Três aspectos merecem ser mencionados: a) 0 crescimento das economias externas de aglomeração tende a gerar deseconomias externas no sentido de que a exagerada concentração eleva os custos gerais de produção, distribuição e transação forçando um deslocamento das atividades para outras áreas fora da metrópole, próximas ou até mais distantes, neste último caso, sobretudo quando incidem incentivos, especialmente fiscais, resultantes de políticas públicas; b) introdução e rápida difusão das novas tecnologias de informação nos sistemas produtivos, de transporte e de comunicação, ampliando os índices de produtividade e tornando as atividades menos dependentes dos fatores de concentração (crescimento das atividades footloose ("pés soltos", livres para ir aonde se quer), ou seja, sem depender dos recursos locais, podendo, por conseguinte, decidir sua localização com maior liberdade de escolha; c) expansão das atividades de turismo, recreação e lazer, que mais interessam a esta análise.

Com relação a este último aspecto, há duas grandes questões que precisam ser destacadas para sua compreensão.

A primeira delas diz respeito, com base em Christaller (1963), ao fato de que o turismo tende a valorizar áreas periféricas, ou seja, áreas distantes das grandes aglomerações (metrópoles) e bastante atraentes quanto às condições naturais e culturais. Assim, Christaller, no mesmo trabalho, mostra um processo seqüencial da produção-reprodução de periferias turísticas (no sentido de áreas distantes dos grandes centros), o que aproxima sua contribuição da proposta do modelo do ciclo do produto em turismo (Butler, 1980). Inicialmente, uma área é descoberta por pintores, poetas, cineastas, gourmets, restaurateurs, hoteleiros, etc., e transformase num lugar da moda. "Com o tempo essa área cresce e se consolida e, a partir daí, passa a ocorrer o deslocamento para novas e remotas periferias, repetindo-se 
os mecanismos de crescimento e assim sucessivamente" (Silva, 1996a, p.13). Desta forma, a expansão é contínua:

\begin{abstract}
Mais e mais novas regiões são abertas para o turismo [...] graças aos aviões e à nossa prosperidade, destinações na África, no Oeste e Sul da Ásia e no Mar do Caribe são competitivas para os países da Europa (é preciso apenas olhar para os anúncios de viagem em nossos jornais metropolitanos) (Christaller, 1963, p.104-105).
\end{abstract}

Nesta perspectiva, a escala das novas periferias é, portanto, global.

Mas, a segunda questão é a de que o turismo também impacta nas grandes aglomerações e em suas periferias imediatas, em uma dinâmica integrada às questões anteriormente colocadas, como fica implícito na contribuição de Christaller. Por exemplo, as grandes metrópoles com importantes centros históricos e outras atrações culturais atrairiam muitos turistas bem como suas áreas próximas e acessiveis com considerável beleza natural e/ou cultural, espraiando os processos de urbanização, como ocorre em Salvador e em parte expressiva de sua periferia, especialmente no litoral Norte.

Por outro lado, o exemplo de Porto Seguro, no distante Extremo Sul baiano, é uma expressão do exemplo de crescimento periférico no turismo superando a metrópole. Com efeito, segundo dados da BAHIATURSA, em novembro de 2006, Porto Seguro tinha 43.460 leitos de hotel e Salvador, em maio do mesmo ano, 33.166 leitos de hotel, o que estabelece uma superioridade de 31\% para Porto Seguro.

Assim, coexistem integradamente duas tendências espaciais na dinâmica recente do turismo mundial, uma "rumo à periferia" (distante) (Drang zur Peripherie, bastante enfatizada por Christaller) e uma direção "rumo ao centro e em sua periferia imediata" (Drang zum Centrum).

O exemplo de Salvador e de sua periferia norte é instignante, como veremos a seguir.

\title{
SALVADOR E O LITORAL NORTE: evolução recente
}

Em 1959, o geógrafo Milton Santos, então no início de sua brilhante carreira, publicou um trabalho na Revista Brasileira dos Municípios com o sugestivo título Salvador e o deserto (Santos, 1959). Nele o autor destaca, após uma série de viagens de observação, "a extrema rarefação do povoamento, a quase completa ausência de vida humana, derredor de uma cidade que beira os 600 mil habitantes" (p. 127). Em várias passagens, Santos se refere a este fato com exemplos do que percebeu no litoral do que hoje é Lauro de Freitas e no litoral de Camaçari, ressaltando, inclusive, a ausência de um "cinturão verde" (p. 127). Assim, Salvador teria em seu entorno, na década de 50 do século passado, um deserto humano. Evidentemente, existiam pequenos e antigos contingentes de populações rurais 
dispersas ou de populações aglomeradas em antigos núcleos de difícil acesso, formados por pescadores e pequenos produtores rurais, como, por exemplo, Abrantes, Arembepe, Monte Gordo e Praia do Forte.

Um outro tipo de deserto iria preocupar o referido mestre e outros autores na época citada: o da histórica, enorme e persistente primazia de Salvador com relação ao sistema urbano do Estado o que justificaria a proposta de uma nova Capital para a Bahia, na região central do Estado, como o fez pioneiramente A. M. de Oliveira, em 1951, também na Revista Brasileira dos Municípios (Oliveira, 1951), propondo Seabra, na área central do estado, como nova capital, e o próprio M. Santos, em 1958, na mesma Revista (Santos, 1958). A inspiração para o uso do termo deserto, na perspectiva urbano-regional, veio do geógrafo Jean-François Gravier que, em 1947, escreveu um livro de grande repercussão, Paris et le désert français. Este livro inspirou a montagem de sólidas estratégias de planejamento territorial na França visando reduzir a primazia de Paris. Recentemente, o professor Marcus Alban retoma este tema na Bahia (Alban, 2005), discutido por Silva e Silva (2006). Portanto, persiste entre nós o desafio de montar estratégias de planejamento urbano-regional que possam melhor equilibrar o sistema urbano e promover 0 desenvolvimento regional.

Os dois desertos acima mencionados - 0 deserto demográfico e a ausência de cidades médias - estão historicamente relacionados, na medida em que Salvador podia drenar diretamente recursos de áreas cada vez mais distantes, dispensando 0 papel de cidades intermediárias, e de áreas produtivas vizinhas, mas vamos priorizar aqui a discussão sobre o que vem acontecendo no litoral Norte da Bahia em função da grande relevância de suas rápidas transformações no contexto metropolitano.

Antes porém, é preciso mencionar a contribuição de um outro geógrafo, o professor Pierre Monbeig (1965) na caracterização da área em meados da década de 60 do século passado. Monbeig afirma que a influência de Salvador só se fazia sentir até o rio Joanes.

A situação muda, radicalmente, além do rio Joanes e, mais ainda, além de Abrantes. A uma distância quilometricamente fraca de Salvador, toda a influência de Salvador termina e, verdadeiramente, tem-se uma zona cujos habitantes participam muito pouco dos circuitos econômicos gerais. [...] 0 estado dos caminhos (a palavra "estrada" parece enganadora) é incompatível com o surto de uma economia agrícola cuja prosperidade seria associada à venda, na Cidade, dos produtos do solo (Monbeig, 1965, p.23).

Um pouco antes, a socióloga Maria Brandão (1959) já havia analisado o distrito de Abrantes/município de Camaçari na perspectiva da economia de subsistência, estudo mais tarde ampliado na sua pesquisa sobre relações agrárias em Camaçari (Brandão, 1975). Só em 1956 foi construída a ponte sobre o rio Joanes o que permitiu a ligação rodoviária até Abrantes (Brandão, 1959, p. 249).

Se os professores Milton Santos e Pierre Monbeig fossem vivos hoje, certamente ficariam espantados com as transformações recentes ocorridas no litoral Norte da Bahia. Em nossos dias, há praticamente um continuum axial urbano entre 
Salvador e Itacimirim, evidentemente com densidades diferenciadas, as mais altas localizando-se mais perto de Salvador. Entretanto, a forte expansão da ocupação humana continua após Itacimirim, agora de forma pontual, mas com tendência a uma futura integração linear. Isto é perfeitamente perceptível para quem viaja pela Estrada de Coco, pela Linha Verde e por avião até Aracaju, inclusive à noite quando é possível ver a extensão da mancha iluminada de forma contínua, até aproximadamente a metade da viagem, e pontos iluminados, isolados, mas próximos entre si, na segunda metade do percurso.

O Mapa 1 exibe, com base em dados dos setores censitários, em 2000, a densidade demográfica da Região Metropolitana de Salvador, com delimitação

\section{Mapa 1 - Densidade demográfica - Região Metropolitana de Salvador e Litoral Norte - 2000}

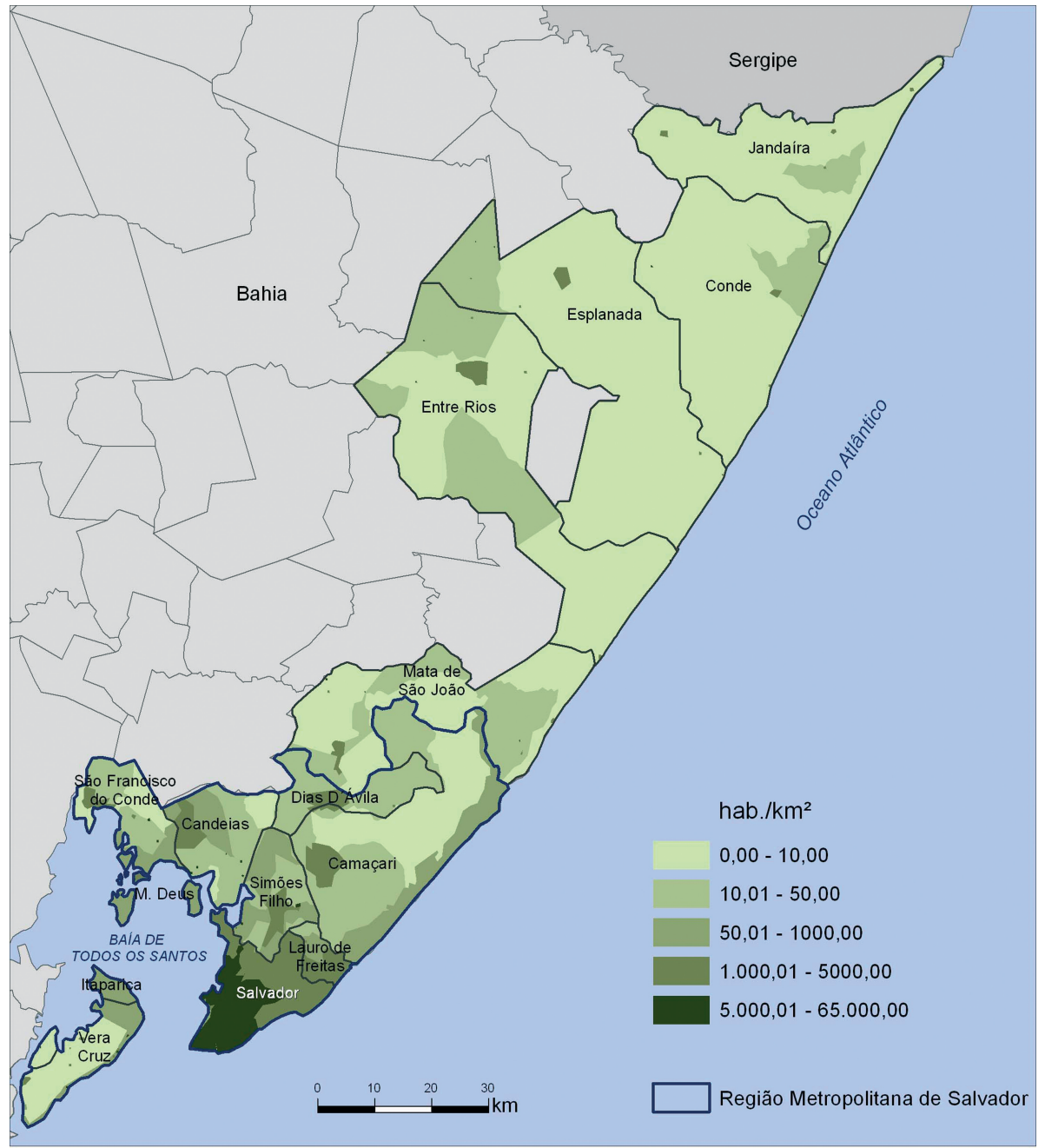


em vigor até dezembro de 2007, e do litoral Norte, confirmando ainda o peso dos testemunhos históricos de Milton Santos e Pierre Monbeig e as observações mais recentes acima relatadas. No litoral Norte foram tomados só os municípios litorâneos, o que excluiu Cardeal da Silva na área centro Norte. Na elaboração do mapa foi utilizada a malha rural dos setores censitários onde os setores dos núcleos urbanos foram agregados. Assim, o litoral de Lauro de Freitas e de Camaçari apresenta densidades elevadas, caindo em Mata de São João, com densidades mais altas no interior do município do que no litoral. Por falta de dados por setores censitários, ainda não é possível fazer o mesmo mapa com base na contagem da população de 2007, o que certamente revelaria importantes transformações.

\section{METROPOLIZAÇÃO TURÍSTICA NO LITORAL NORTE DE SALVADOR}

As causas da forte expansão da metropolização ao norte de Salvador, desde meados da década de 70 do século passado, são destacadamente: 0 rompimento do isolamento do acesso por via rodoviária, com a construção da Estrada do Coco, em 1975, e da Linha Verde, em 1993 (Mapa 2), o potencial de uso do território para turismo, recreação e lazer (incluindo residências secundárias) e, de forma integrada, o rápido crescimento de Salvador e de sua Região Metropolitana. Salvador cresce de 1.502.013 habitantes em 1980 para 2.892.625 habitantes em 2007 (93\%) e sua região metropolitana de 1.766 .724 para 3.599 .538 habitantes (104\%) no mesmo período.

Por conseguinte, a urbanização neste eixo Norte, provocada pelo rápido crescimento das atividades de turismo, recreação e lazer, incluindo a opção pela segunda residência, foi e é intensa. Um novo tipo de cidade está sendo aí construído: uma extensa cidade linear, resultado de um forte papel empreendedor do Estado, sobretudo ligada ao consumo, bastante dependente da metrópole, sem um centro, extremamente segregada, com sérios problemas ambientais e de relacionamento com as populações tradicionais, remanescentes dos períodos anteriores. São ainda espaços com graves problemas de acessibilidade interna e externa e espaços desprovidos de mecanismos institucionais de gestão compatíveis com as mudanças em curso, apesar de sua expansão ser formatada pelo setor público. Por outro lado, esta expansão, com melhor acessibilidade a Salvador, causou progressivamente uma crise na ilha de Itaparica, tradicionalmente o principal lugar da segunda residência dos moradores de Salvador, mas dependente do problemático sistema de ferry boat.

Várias das características acima apontadas aproximam-se bastante do que define o sociólogo australiano Patrick Mullins (1991) como urbanização turística, que seria: (i) espacialmente diferente porque é socialmente diferente, (ii) simbolicamente distintiva, com símbolos urbanos agindo como atrativos para turistas, 
Mapa 2 - Sistema viário - Região Metropolitana de Salvador e Litoral Norte - 2007

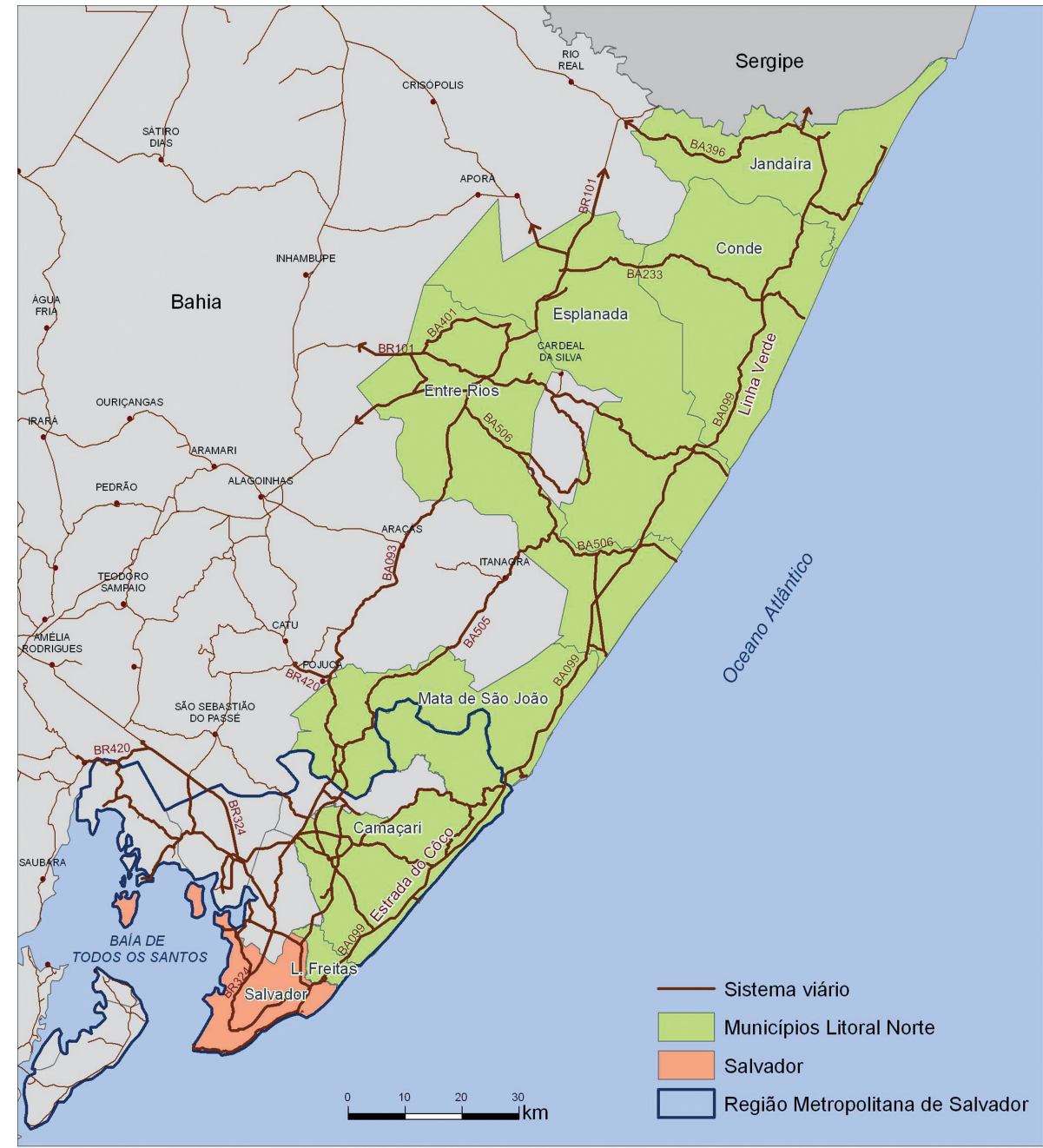

Fonte: IBGE/DERBA -2007

Elaboração: CARVALHO, S. S.; SILVA, B. C. N.

(iii) distinguida pelo rápido crescimento da população e da força de trabalho, (iv) diferenciada por um sistema flexível de produção porque é parte do pós-fordismo, (v) caracterizada por uma forma espacial de intervenção do Estado a qual é "empreendedora" no estilo como o é a cidade pós-moderna, (vi) distinguida por um consumo do prazer, costumeiro e de massa, e (vii) diferenciada por uma população residente que é socialmente diferente, porque esta urbanização é socialmente diferente.

De certa forma, estas características do litoral Norte da Bahia, aproximamse das áreas de urbanização dispersa definidas pelo arquiteto Nestor Goulart Reis (2006), com a grande diferença de sua especificidade ser ligada ao turismo, recreação e lazer, bastante dependente de uma metrópole, Salvador. 
Viajando pela área e buscando informações sobre a dinâmica atual e suas perspectivas, fica uma enorme preocupação com o futuro do litoral Norte: ele corre o sério risco de se tornar um eixo urbanizado desprovido do que é lógico na existência de uma cidade, como diria o geógrafo Paul Claval (1981), ou seja, desprovido da capacidade de promover a interação sócio-territorial. A área, cortada por uma problemática rodovia pedagiada (desde 2001) e em fase de duplicação, sintomaticamente, até Itacimirim (e planejada até Praia do Forte), que divide axialmente 0 litoral e 0 interior, está sendo ocupada prioritariamente por médios e grandes condomínios residenciais fechados e por enormes resorts de padrão internacional, com áreas residenciais, que também impedem, no conjunto, a construção de uma idéia de cidade. Muitas residências estão sendo vendidas para brasileiros de outros estados e para europeus e americanos. Está se produzindo aí um território de enclaves, ou de guetos de luxo, "devoradores" de paisagens naturais e culturais (Landschaftsfresser), como diria o sociólogo suíço Jost Krippendorf ao se referir aos resorts internacionais. São territórios auto-segregados que passam a ter predominância na área. Estes crescem sem parar como freqüentemente relata a imprensa. Segundo informações da Secretaria de Turismo, divulgadas na Gazeta Mercantil (08/01/2007, p. C5) há cinco novos projetos em andamento de hotéisresorts e de condomínios residenciais de empresas da Espanha (Trusan, Riu, Playa, GrupAce e Sol Meliá). Um deles será na praia de Baixio, a $120 \mathrm{~km}$ de Salvador, onde o grupo adquiriu uma extensa faixa litorânea de $13 \mathrm{~km}$. Há perspectivas de mais 10 resorts nesta área. Empresários belgas já implantaram em Subaúma um hotel e um condomínio residencial e empresários suecos e japoneses também estão interessados em investir no litoral Norte.

Recentemente, o mesmo jornal Gazeta Mercantil escreve:

No primeiro semestre será iniciada a construção do Complexo Turístico Guarajuba-Bahia, no Distrito de Camaçari, a $42 \mathrm{~km}$ de Salvador. A primeira etapa do empreendimento deve receber US\$120 milhões para a construção de um hotel com cerca de 300 apartamentos. 0 projeto, no entanto, é mais audacioso. Serão quatro hotéis e mil quartos, um condomínio com 1,5 mil casas e um centro de convenções para 1,5 mil pessoas. O projeto total na área de cinco milhões de $\mathrm{m}^{2}$, adquirida no final de 2007 na Estrada de Coco, vai demandar recursos de US\$ 600 milhões (Oliveira, 23/01/2008, p.C6)

Com o sugestivo título "Gringos avançam no litoral", assim descreve $A$ Tarde: No litoral norte, mais precisamente em Baixios (Esplanada), o Grupo Arc, ou Grupace, espanhol, comprou área que dá 14 quilômetros de praia. Um pouco mais pra cima, em Jandaíra, o Invisa, também espanhol, levou 4,5 quilômetros. Mais perto de Salvador, na valorizada Guarajuba (Camaçari), o Meliá pegou dois quilômetros. Sem contar os brasileiros, como Daniel Dantas, que resolveram comprar paraísos litorâneos baianos (Vasconcelos, 24/03/2008, p.2).

O mesmo texto relata a compra de terras pelo rei e rainha da Suécia em Nilo Peçanha, ao Sul de Salvador. 


\section{VENDE-SE UMA REGIÃO: cartografia da metropolização turística ao norte de Salvador}

Entende-se por metropolização turística o processo de expansão da região metropolitana preponderantemente centrada nas atividades de turismo, recreação e lazer, resultando em intensos mecanismos de interação entre a metrópole e a nova área.

No caso de Salvador, a inserção desse eixo metropolitano turístico se dá complementando o importante processo de metropolização provocado pelo setor industrial.

Com efeito, nos anos 50 do século passado, o tradicional papel metropolitano de Salvador, centrado no comércio, no setor político-administrativo e em outros serviços, exerce-se com certa intensidade sobre o quase adormecido Recôncavo canavieiro, fumageiro, mandioqueiro e da pecuária, e, com menos intensidade, sobre o restante do Estado (Costa Pinto, 1958; Barickman, 2003). Mas, os germes das grandes transformações que iriam atuar já estavam sendo implantados: a Refinaria de Mataripe, em São Francisco do Conde e a exploração do petróleo no Recôncavo central e norte (Azevedo, 1998). Em 1963, ocorre a integração rodoviária da Bahia com o Sudeste e o Nordeste com o asfaltamento da BR-116, expressando a unificação do mercado nacional, rompendo, portanto, sua característica de isolamento dentro do cenário, proposto por Francisco de Oliveira, de arquipélago regional (Oliveira, 1977 e 1990), retomado por Santos e Silveira (2001).

Assim, ao histórico e, sobretudo, agrário e mercantil Recôncavo junta-se progressivamente o do petróleo e, mais tarde, o da moderna indústria, com o Centro Industrial de Aratu (criado em 1965) e o Pólo Petroquímico de Camaçari (criado em 1972). É este dinamismo que vai justificar a inclusão de Salvador na lei que criou as regiões metropolitanas, no Brasil, em 1973. No início deste século XXI, cresce e se diversifica o setor industrial em Camaçari com o Complexo Industrial da Ford, com indústrias de pneus e com novas indústrias químicas. É sintomático registrar a rápida redução dos estudos e projetos sobre o Recôncavo e a emergência de trabalhos sobre a Região Metropolitana de Salvador, no início dos anos 70 do século passado. E isto é claramente expressivo na sigla CONDER, órgão criado pelo Estado da Bahia. Inicialmente, foi implantado como Conselho de Desenvolvimento do Recôncavo (1967) e, em 1973, passa a ser Companhia de Desenvolvimento da Região Metropolitana de Salvador (Brandão, 1998a), e, desde 1998, Companhia de Desenvolvimento Urbano do Estado da Bahia, mantendo-se a mesma sigla.

A dimensão espacial é diminuída: do velho, agrário e amplo Recôncavo (de difícil delimitação, por sinal) ao novo denso e reduzido espaço metropolitano, definido administrativamente e assentado fundamentalmente sobre a indústria, portanto, associado ao padrão urbano-industrial.

Com a implantação da Estrada do Coco (BA-099) primeiro até Itacimirim, em 1975, e depois até Praia do Forte, em 1980, começa um novo e vigoroso processo, o da expansão litorânea ao Norte de Salvador que prosseguiu até a divisa com 
Sergipe com a construção do prolongamento chamado de Linha Verde, em 1993. Desta forma, a expansão metropolitana ao Norte de Salvador pode ser analisada no seu impacto sobre os fluxos entre a metrópole e o novo vetor de crescimento, como fica destacado no Gráfico 1 que apresenta a média de veículos que passam por dia no pedágio instalado no km 14 (o quilômetro zero fica na divisa entre Salvador e Lauro de Freitas) da rodovia BA-099/Estrada do Coco. Há uma variação entre os meses de férias (dezembro, janeiro e fevereiro), com destaque para janeiro, com relação aos outros meses, mas, surpreendentemente, isto não acontece em julho. A média diária de veículos é sempre maior nos dias de sábado e domingo o que é um relevante indicador do papel metropolitano de Salvador através da segunda residência e do turismo em hotelaria nos fins de semana, estimulado, em vários períodos do ano, por tarifas reduzidas para baianos e sergipanos, inclusive para programas de uso diário (day use). Além deste aspecto, a metropolização turística ao Norte de Salvador é uma decorrência do papel do seu Aeroporto Internacional (o $5^{\circ}$ do país em movimento de passageiros), dos serviços metropolitanos, particularmente relacionados com logística, dos recursos humanos e do próprio produto turístico da capital que é sempre integrado ao do novo eixo de expansão. Parte expressiva da força de trabalho empregada nos hotéis e resorts do litoral Norte reside em Salvador, particularmente a de mais alta qualificação profissional. A rápida expansão das segundas residências, construídas por moradores de Salvador nesse eixo insere-se neste processo. É a metropolização turística que acontece, como vimos pari passu com as mudanças institucionais ocorridas na CONDER, ou seja, sem a presença de processos institucionais de planejamento e gestão regional justamente no período em que mais se justifica, do ponto de vista geográficoeconômico e sócio-político, a existência da Região Metropolitana de Salvador. Esta, por sinal, foi recentemente ampliada, com a integração dos municípios de São Sebastião do Passé e Mata de São João (Lei Complementar no 30 de 03/01/2008, sem apontar para estudos básicos), mas até agora (abril/2008) não ocorreram mudanças institucionais importantes. Neste trabalho, ainda é tomada a divisão anterior, entretanto é preciso destacar que a incorporação de Mata de São João à Região Metropolitana de Salvador certamente deve-se ao papel do turismo no seu litoral e de São Sebastião do Passé ao setor industrial e outros serviços, especialmente relacionados com a exploração do petróleo no Recôncavo.

Em 2007, a Concessionária Litoral Norte, que administra a rodovia, estima que houve uma redução de $37 \%$ causada por medidas que provocaram desvios do local de cobrança do pedágio, tomadas pela Prefeitura Municipal de Camaçari. A empresa avalia também que, sem o efeito da rota de fuga, o tráfego é em $52 \%$ no sentido Norte e $48 \%$ no sentido Salvador, demonstrando que esta via é bastante utilizada para quem se destina a Sergipe e outros estados do Nordeste.

Inicialmente, na análise das questões atuais da metropolização turística ao Norte de Salvador, a Tabela 1 apresenta os principais investimentos implantados e previstos nos pólos turísticos do litoral da Bahia, no início de 2008. 
Gráfico 1 - Média de veículos por dia da semana - Pedágio da BA-099 - 2001, 2004 e 2007
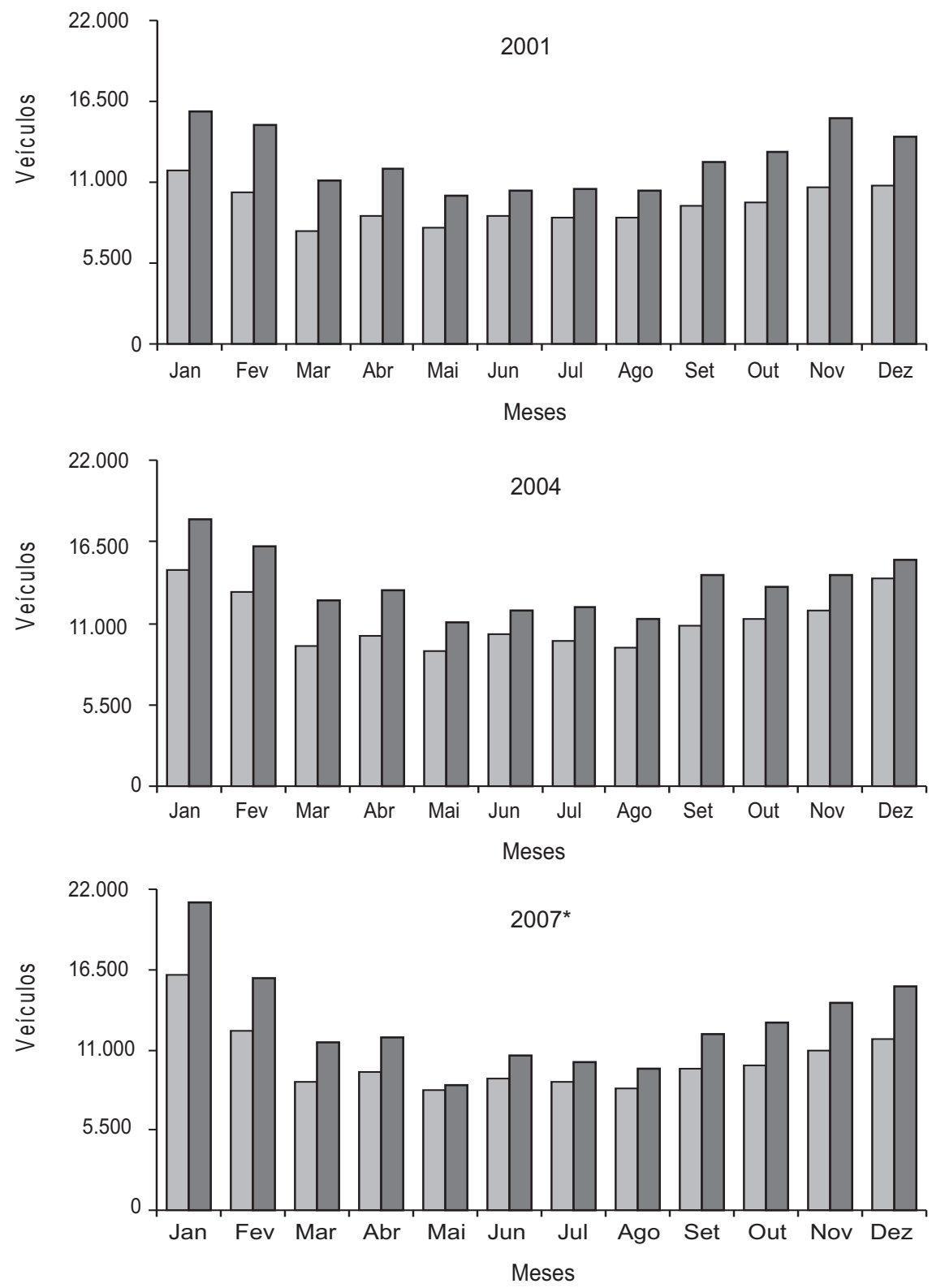

Segunda à Sexta $\quad \square$ Sábado e Domingo

Fonte: Concessionária Litoral Norte.

$\left({ }^{*}\right)$ A Concessionária Litoral Norte calcula que, em 2007, ocorreu uma redução de $37 \%$ causada por desvios implantados pela Prefeitura Municipal de Camaçari. 
METROPOLIZAÇÂO E TURISMO NO LITORAL NORTE DE SALVADOR: DE UM DESERTO...

Tabela 1 - Principais investimentos privados em implantação/previstos - Pólos turísticos da Bahia - janeiro 2008

\begin{tabular}{l|r|r|r|r|r|r}
\hline \multicolumn{1}{|c|}{ Empreendimentos } & $\begin{array}{c}\text { Investimentos } \\
\text { estimados } \\
\text { (em mil US\$) }\end{array}$ & $\begin{array}{c}\text { Unidades } \\
\text { habitacionais }\end{array}$ & $\begin{array}{c}\text { Empreendimen- } \\
\text { tos } \\
\text { estrangeiros } \\
(\%)\end{array}$ & $\begin{array}{c}\text { Em } \\
\text { implantação } \\
(\%)\end{array}$ & $\begin{array}{c}\text { Planejados } \\
(\%)\end{array}$ & $\begin{array}{c}\text { Empregos } \\
\text { diretos }\end{array}$ \\
\hline Costa dos Coqueiros & $2.458 .635,0$ & 19.400 & 93,75 & 13,33 & 86,67 & 12.693 \\
\hline Costa do Dendê & $17.500,0$ & 33 & 0,00 & 0,00 & 100,00 & 60 \\
\hline Costa do Cacau & $125.000,0$ & 329 & 50,00 & 25,00 & 75,00 & 410 \\
\hline Costa do Descobrimento & $140.000,0$ & 975 & 40,00 & 20,00 & 80,00 & 1.000 \\
\hline Baia de Todos os Santos & $822.775,5$ & 4.591 & 46,67 & 50,00 & 50,00 & 4.480 \\
\hline Total & $3.563 .910,5$ & 25.328 & - & - & - & 18.643 \\
\hline
\end{tabular}

Fonte: SUINVEST, 03/01/2008

O pólo turístico Costa dos Coqueiros, que corresponde ao litoral Norte da Bahia, é de longe o mais importante de todos, com $69 \%$ dos investimentos, $77 \%$ das unidades habitacionais e $68 \%$ dos empregos. Há uma elevadíssima presença dos investimentos estrangeiros e pelo fato que apresenta alta porcentagem de empreendimentos planejados, significa dizer que o maior impacto dos mesmos terá início só nos próximos anos. Não há indicações oficiais disponíveis sobre empreendimentos turísticos em pólos do interior, o que pode estar ocorrendo mesmo sem registro na Superintendência de Investimentos em Pólos Turísticos (SUINVEST), da Secretaria de Turismo do Estado da Bahia.

A Tabela 2 mostra a evolução da implantação dos grandes resorts na Bahia. O pioneiro foi o Club Med/Itaparica seguido pelo Praia do Forte Eco Resort, cinco anos após a rodovia asfaltada ter chegado na localidade, e o mais recente é - Gran Hotel Stella Maris Resort \& Conventions, recém inaugurado, o primeiro grande resort all inclusive de Salvador (A Tarde, 28/02/2008, p.6). Em termos

Tabela 2 - Ano de inauguração de grandes empreendimentos tipo resort em operação na Bahia e número de unidades habitacionais

\begin{tabular}{l|c|c}
\multicolumn{1}{c|}{ Empreendimentos } & Inauguração & Unidades habitacionais \\
\hline Club Med / Itaparica & 1979 & 330 \\
\hline Praia do Forte Eco Resort / Praia do Forte & 1985 & 304 \\
\hline Transamérica Ilha de Comandatuba / Una & 1989 & 363 \\
\hline Fronteira Tropical / Itacimirim & 1994 & 144 \\
\hline Costa do Sauípe / Mata de São João & 2000 & 1.587 \\
\hline Club Med / Trancoso & 2002 & 250 \\
\hline Vila Galé Marés / Guarajuba & 2006 & 447 \\
\hline Iberostar / Praia do Forte & 2006 & 632 \\
\hline Gran Hotel Stella Maris Resort / Salvador & 2008 & 334 \\
\hline Font: Gúa Quto Rodas Brasi 2007e 2008; A tarde & \\
\hline
\end{tabular}

Fonte: Guia Quatro Rodas Brasil, 2007 e 2008; A Tarde, 28/02/08, Caderno Turismo, p.6. 
regionais, o litoral Norte concentra o maior número de resorts e, dentre todos os resorts da Bahia, possui o maior deles, o Complexo Hoteleiro Costa do Sauípe, com 1.587 unidades habitacionais.

O litoral Norte é igualmente o pólo turístico que mais tem crescido em número de leitos entre 2001 e 2006 no litoral do Estado da Bahia, conforme consta na Tabela 3. Esta comparação pode ser visualizada no Gráfico 2 onde a Costa dos Coqueiros destaca-se como o terceiro pólo do litoral do Estado da Bahia, após a Costa do Descobrimento e Salvador.

Tabela 3 - Crescimento dos leitos de hotel

Pólos turísticos do litoral do estado da Bahia - 2001 e 2006

\begin{tabular}{l|c|c|c|c}
\hline \multicolumn{1}{c|}{ Pólos turísticos } & $\mathbf{2 0 0 1}$ & $\mathbf{2 0 0 6}$ & $\begin{array}{c}\text { Crescimento } \\
\text { absoluto no período }\end{array}$ & $\begin{array}{c}\text { Crescimento } \\
\text { relativo no período } \\
(\%)\end{array}$ \\
\hline Salvador & 22.516 & 33.261 & 10.745 & 47,7 \\
\hline Baía de Todos os Santos & 6.049 & 7.543 & 1.494 & 24,7 \\
\hline Costa dos Coqueiros & 11.611 & 18.917 & 7.306 & 62,9 \\
\hline Costa do Dendê & 9.277 & 13.587 & 4.310 & 46,5 \\
\hline Costa do Cacau & 11.755 & 15.017 & 3.262 & 27,7 \\
\hline Costa do Descobrimento & 35.609 & 48.018 & 12.409 & 34,8 \\
\hline Costa das Baleias & 9.527 & 12.493 & 2.966 & 31,1 \\
\hline
\end{tabular}

Fonte: BAHIATURSA.

Analisando de perto a evolução recente do turismo no litoral Norte da Bahia, uma série de cartogramas espacializa os principais indicadores. Os primeiros deles, Mapas 3 e 4, analisam os empreendimentos turísticos privados em operação e em implantação/previstos, situação de maio de 2006. Estes últimos empreendimentos se concentram em uma faixa intermediária do litoral Norte, de Itacimirim até parte do litoral de Entre Rios.

Em pouco tempo, janeiro de 2008, a situação muda. O Mapa 5, com os empreendimentos turísticos privados em implantação ou previstos, mostra uma distribuição um pouco mais ao Norte da faixa intermediária apontada na figura anterior, mas esta faixa é ainda a que concentra o maior número de unidades habitacionais em implantação ou previstos (Mapa 6) .

A análise dos investimentos, Mapa 7, apresenta uma distribuição espacial novamente com destaque para a faixa intermediária. A indicação dos empregos tem também uma grande concentração entre Itacimirim e Praia do Forte (Mapa 8) que ressalta a concentração dos novos empregos na área de Itacimirim - Praia do Forte e Imbassaí.

Detalhando as informações, a Tabela 4 fornece informações para dimensionar, com base em dados oficiais, os principais investimentos previstos no litoral Norte da Bahia, situação de janeiro de 2008. Como fica evidente, a maioria absoluta dos investimentos é de porte muito grande e isto em um contexto internacional. 
Tabela 4 - Principais investimentos turísticos privados em implantação/previstos - Litoral Norte - janeiro 2008

\begin{tabular}{|c|c|c|c|c|c|c|c|}
\hline Empreendimento & Origem & Localização & UHs & $\begin{array}{l}\text { Previsão de } \\
\text { abertura }\end{array}$ & $\begin{array}{l}\text { Investimento } \\
\text { estimado (US\$) }\end{array}$ & Situação & $\begin{array}{c}\text { Empregos } \\
\text { diretos }\end{array}$ \\
\hline Costa dos Coqueiros & & & 19.400 & & 2.458 .635 .000 & & 12.693 \\
\hline Hotel Comfort Aeroporto & Nacional & Lauro de Freitas & 132 & $\mathrm{mar} / 2009$ & 4.000 .000 & Planejamento & 90 \\
\hline Complexo Sol Meliá - 1a etapa (Gran Meliá + Condor Hotel) & Espanha & Genipabu / Camaçari & 450 & out/2009 & 100.000 .000 & Planejamento & 250 \\
\hline Complexo Sol Meliá - 2a etapa (Meliá Alphaville) com residências & Espanha & Genipabu / Camaçari & 550 & dez/2009 & 150.000 .000 & Planejamento & 500 \\
\hline Le Carlo / Les Terrasses & França & Itacimirim / Camaçari & 195 & $\mathrm{jul} / 2009$ & 10.435 .000 & Planejamento & 140 \\
\hline Iberostar Bahia (2a etapa) com residências & Espanha & $\begin{array}{l}\text { Praia do Forte / Mata } \\
\text { de São João }\end{array}$ & 540 & ago/2008 & 100.000 .000 & Implantação & 540 \\
\hline Iberostar Bahia (3a etapa) com residências & Espanha & $\begin{array}{l}\text { Praia do Forte / Mata } \\
\text { de São João }\end{array}$ & 250 & ago/2009 & 20.000 .000 & Planejamento & 400 \\
\hline Complexo Turistico em Praia do Forte 1a etapa / Grupo TRUSAM & Espanha & $\begin{array}{l}\text { Praia do Forte / Mata } \\
\text { de São João }\end{array}$ & 600 & dez/2008 & 80.000 .000 & Planejamento & 2.500 \\
\hline $\begin{array}{l}\text { Complexo Turístico em Praia do Forte } 2 a \text { etapa / Grupo TRUSAM com } \\
\text { residências }\end{array}$ & Espanha & $\begin{array}{l}\text { Praia do Forte / Mata } \\
\text { de São João }\end{array}$ & 7.000 & $\mathrm{jan} / 2014$ & 1.270 .000 .000 & Planejamento & 5.000 \\
\hline Reserva Imbassaí All Inclusive (1a etapa) / Reta Attântico & $\begin{array}{c}\text { Portugal / } \\
\text { Espanha }\end{array}$ & $\begin{array}{l}\text { Imbassaí / Mata de } \\
\text { São João }\end{array}$ & 350 & $\mathrm{jan} / 2008$ & 35.700 .000 & Implantação & 340 \\
\hline Reserva Imbassaí - Beach Resort (2a etapa) / Reta Atlântico & Portugal & $\begin{array}{l}\text { Imbassaí / Mata de } \\
\text { São João }\end{array}$ & 250 & $\mathrm{jan} / 2009$ & 30.000 .000 & Planejamento & 200 \\
\hline Reserva Imbassaí (3a etapa) / Reta Atlântico & Portugal & $\begin{array}{l}\text { Imbassaí / Mata de } \\
\text { São João }\end{array}$ & 200 & $\mathrm{jan} / 2012$ & 20.000 .000 & Planejamento & 200 \\
\hline Orissio Sul & Itália & $\begin{array}{l}\text { Imbassaí / Mata de } \\
\text { São João }\end{array}$ & 533 & $\mathrm{jan} / 2010$ & 14.500 .000 & Planejamento & 533 \\
\hline Orissio Norte & Itália & $\begin{array}{l}\text { Imbassaí / Mata de } \\
\text { São João }\end{array}$ & 1.500 & $\mathrm{jan} / 2012$ & 104.000 .000 & Planejamento & 1.500 \\
\hline Fazenda Costa Azul / Grupo Invisa & Espanha & Jandaíra & 2.500 & - & - & Planejamento & - \\
\hline Bahia dos Coqueiros / Grupo Lena com residências & Portugal & Jacuípe / Camaçari & 350 & dez/2009 & 220.000 .000 & - & 500 \\
\hline Complexo Turístico - imobiliário GruAce com residências & Espanha & Esplanada - Baixios & 4.000 & dez/2009 & 300.000 .000 & Planejamento & - \\
\hline
\end{tabular}


Mapa 3 - Empreendimentos turísticos privados em operação - Litoral Norte - maio 2006

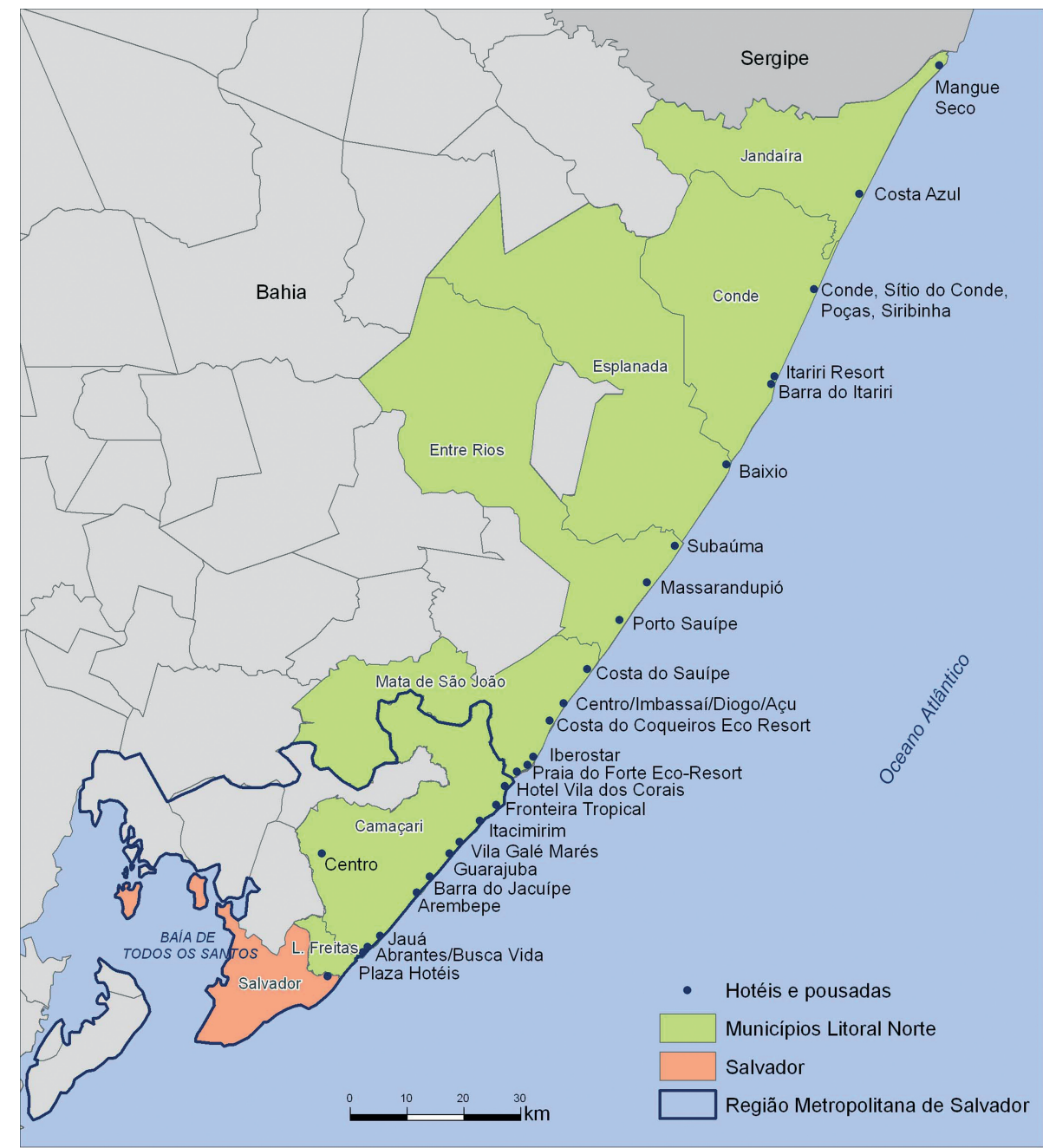

Fonte: SUINVEST - maio 2006

Elaboração: CARVALHO, S. S.; SILVA, B. C. N.

É preciso ressaltar que este levantamento é feito mensalmente pelo Estado da Bahia, o que fornece um importante indicador da velocidade deste processo.

Finalmente, o Mapa 9 exibe a distribuição dos leitos de hotel onde Salvador ocupa o primeiro lugar seguida por Mata de São João em função incorporadas ao tecido urbano, o que fazia com que as segundas residências fossem deslocadas para mais longe e assim sucessivamente.

Por exemplo, Salvador teve conjuntos de segunda residência, hoje plenamente integrados à mancha urbana, em áreas como Rio Vermelho, Amaralina (onde ainda existe uma rua do Balneário), Pituba e daí até Itapuã, além da ilha de Itaparica (Santana, 2002). Agora, o litoral Norte da Bahia recebe muitos estrangeiros 
Mapa 4 - Empreendimentos turísticos privados em implantação/previstos - Litoral Norte - maio 2006

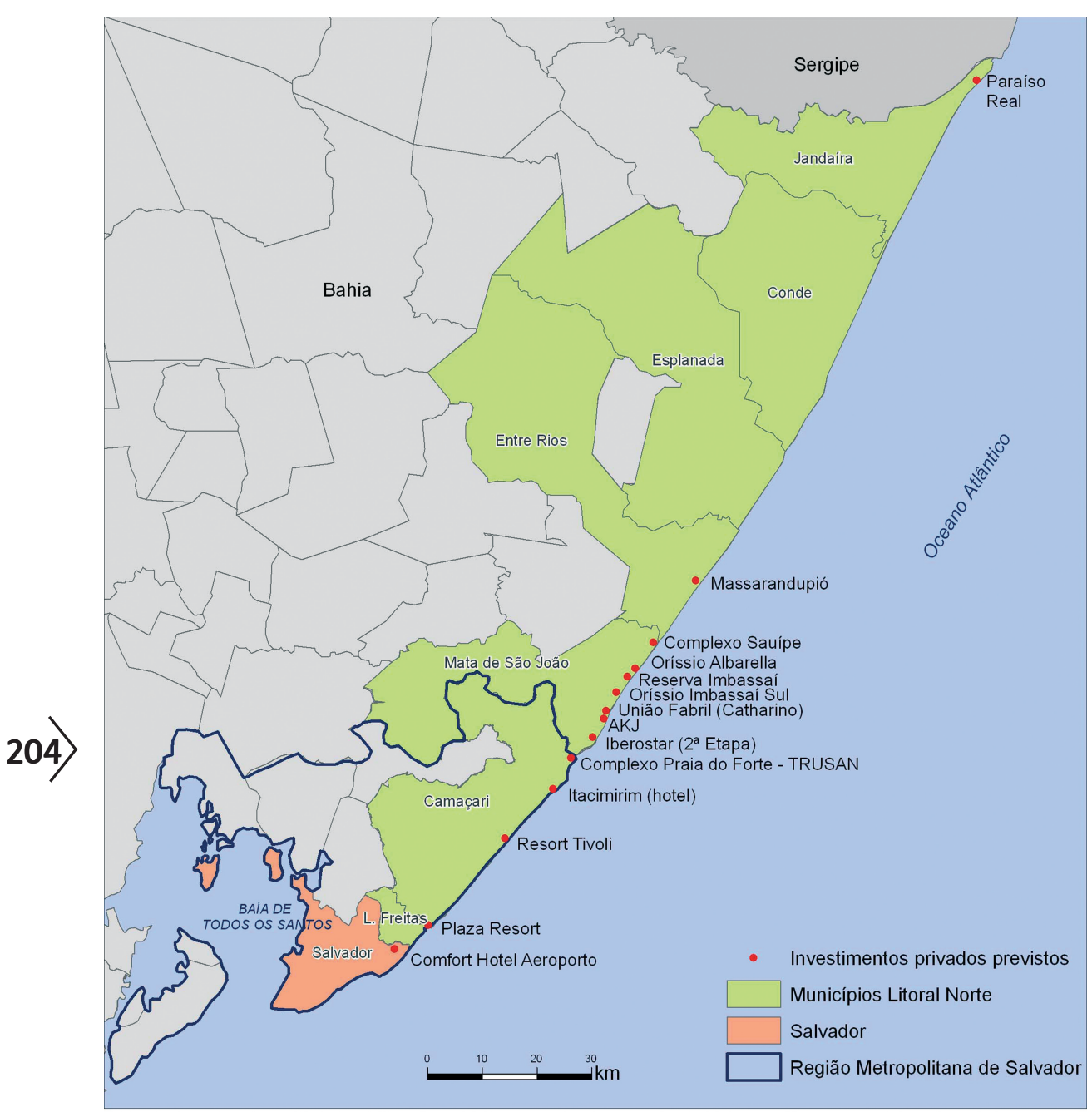

Fonte: SUINVEST - maio 2006

Elaboração: CARVALHO, S. S.; SILVA, B. C. N.

que compram residências de férias dinamizando bastante 0 mercado imobiliário em grandes projetos associados a condomínios e a hotéis e resorts. 0 Complexo Costa do Sauípe foi um dos pioneiros na área construindo vários núcleos residenciais de luxo em diversas etapas.

Isto expressa mais uma característica da aceleração do processo de globalização em rede, integrando a metropolização turística em seu contexto internacional e local, como vimos anteriormente. Assim, o processo de expansão das residências de férias de ingleses em Portugal e de alemães e franceses na Espanha, delineado nas décadas de 60 e 70 do século passado, tem hoje uma 


\section{Mapa 5 - Empreendimentos turísticos privados em implantação/previstos} Litoral Norte - janeiro 2008

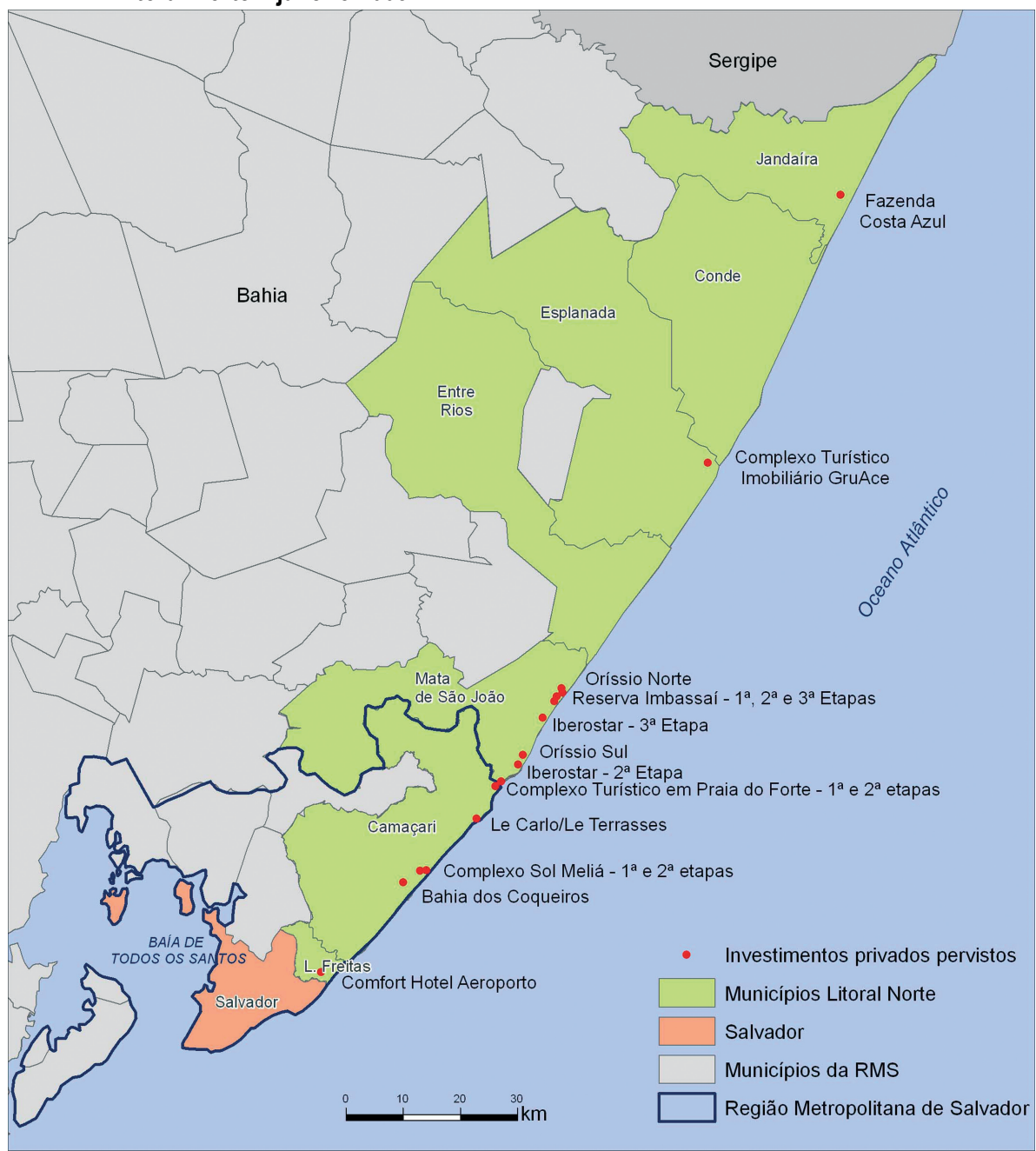

Fonte: SUINVEST - janeiro 2008

Elaboração: CARVALHO, S. S.; SILVA, B. C. N.

clara dimensão global. No litoral Norte, os loteamentos para segunda residência começam no início dos anos 70 do século passado (por exemplo, Loteamento Guarajuba), portanto, antes da Estrada do Coco, o que é um bom indicador da perspicácia do mercado imobiliário. Mas, este dinamismo todo enfrenta crises e conflitos na Bahia, a começar pelo pioneiro mega-projeto do Complexo Costa do Sauípe. Em julho de 2007, a rede francesa Sofitel deixou de operar os dois hotéis sob sua bandeira no Complexo e em março de 2008 foi anunciada para $1^{\circ}$ de junho de 2008 a saída da rede americana Marriott que também administra dois hotéis em Sauípe. O hotel Fronteira Tropical, implantado por italianos em 1994, dá sinais 
Mapa 6 - Empreendimentos turísticos privados em implantação/previstos Unidades habitacionais (UHs) - Litoral Norte - janeiro 2008

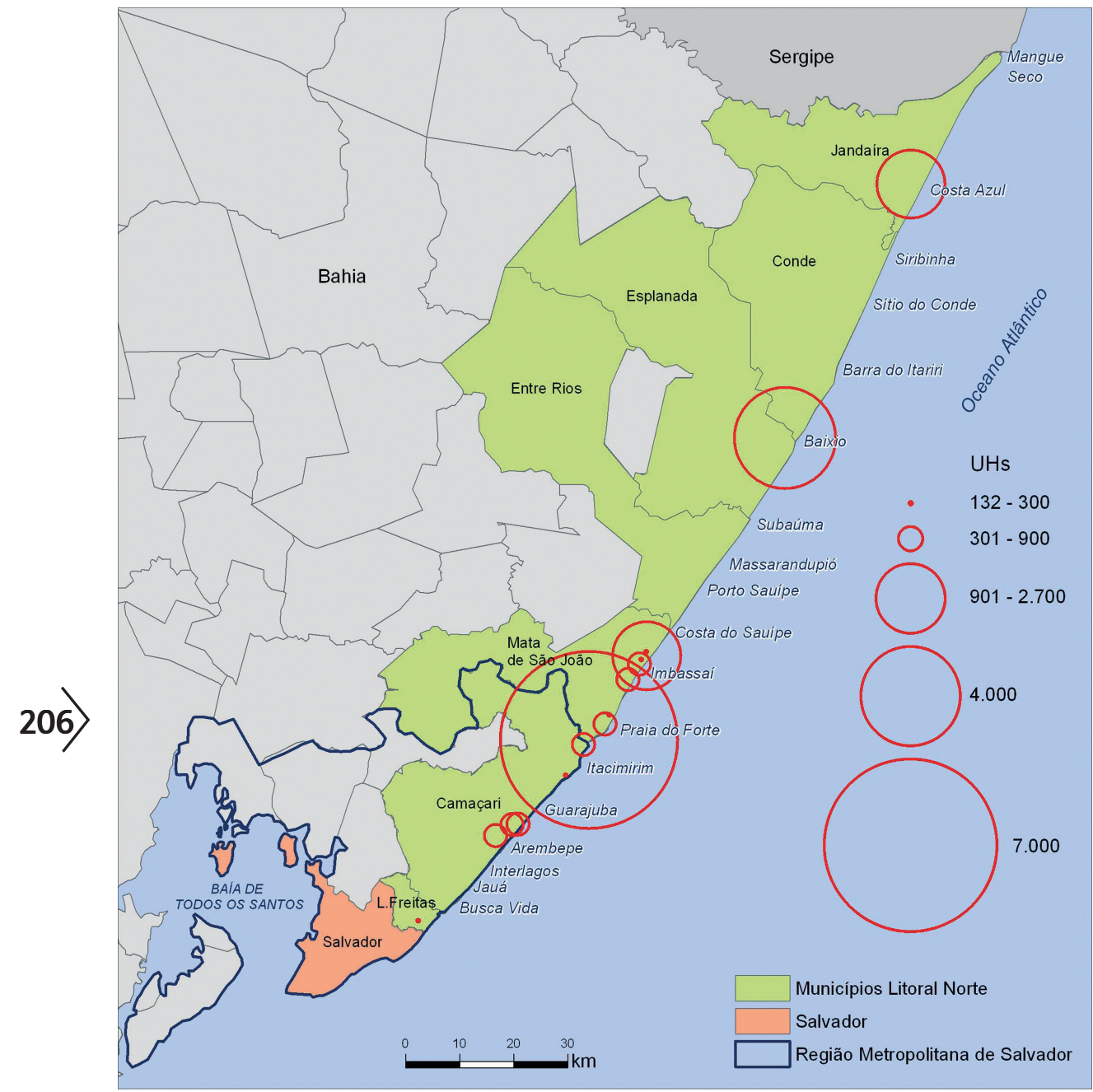

Fonte: SUINVEST - janeiro 2008

Elaboração: CARVALHO, S. S.; SILVA, B. C. N.

evidentes de crise expressos pelo seu precário funcionamento. Em Salvador, não há atualmente nenhuma empresa operadora de turismo que trabalha com este hotel.

Crescem, igualmente os conflitos ambientais envolvendo grandes projetos de hotelaria e de residências em Áreas de Proteção Ambiental bem como com as comunidades locais relacionados, por exemplo, com problemas de esgotamento sanitário e resíduos sólidos.

Por outro lado, com o modelo em curso de metropolização turística no litoral Norte da Bahia, percebe-se que Salvador difunde, de forma particular, a sua segmentação sócio-espacial expressa, por exemplo, pelo eixo das Avenidas ACM 
Mapa 7 - Empreendimentos turísticos privados em implantação/previstos Investimentos estimados - Litoral Norte - janeiro 2008

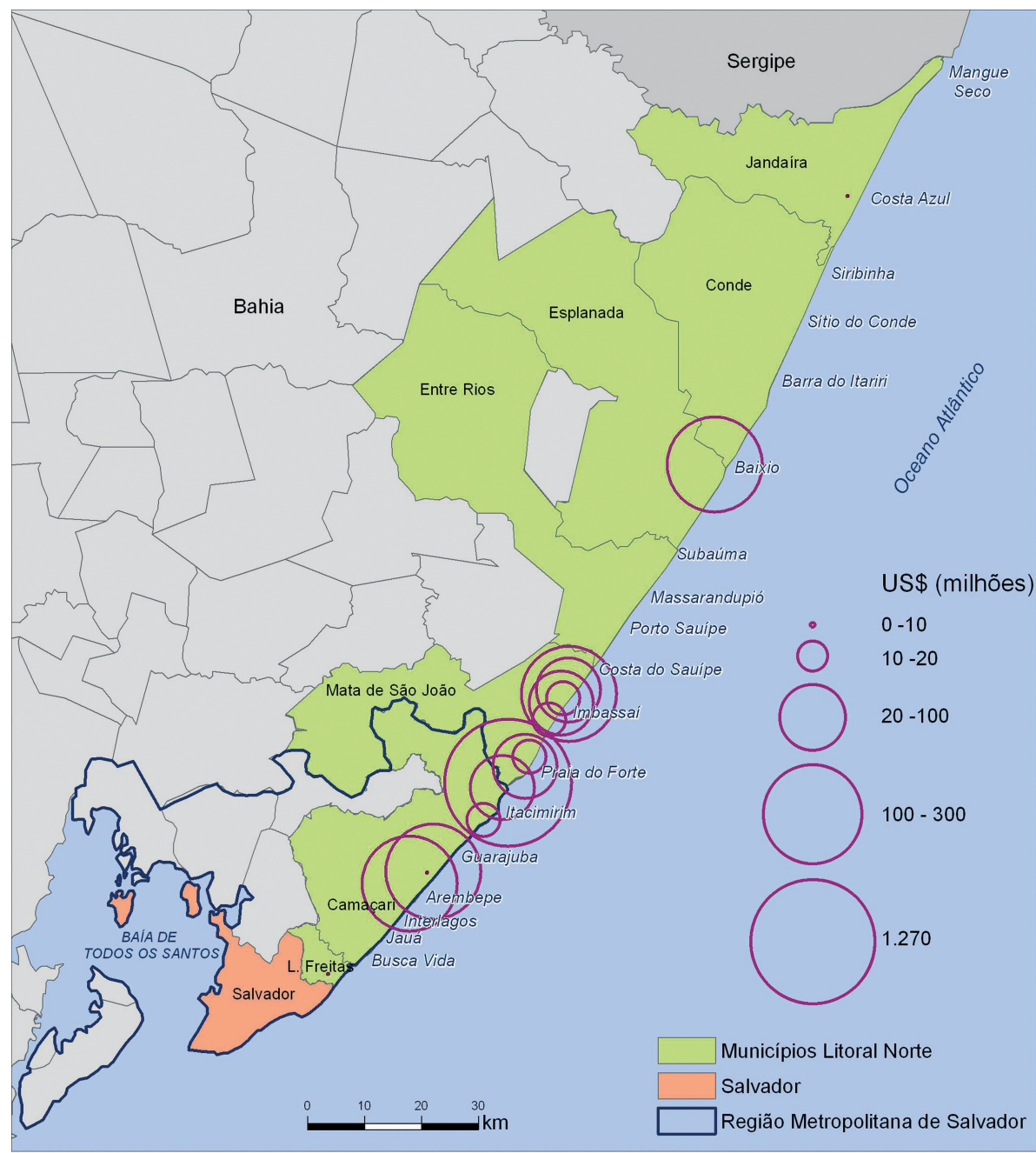

Fonte: SUINVEST - janeiro 2008

Elaboração: CARVALHO, S. S.; SILVA, B. C. N.

(parte), Tancredo Neves e Paralela (Carvalho; Pereira, 2006): a leste teríamos as classes de renda mais elevada e a oeste as de renda mais baixa. É, esquematicamente, a segmentação centro, orla, subúrbio e o chamado miolo de Salvador. A particularidade no litoral Norte, com a Estrada do Coco e Linha Verde servindo de demarcação, reside na força da segmentação leste-oeste, provocada pelas atividades de turismo, recreação e lazer.

Finalmente, deve ser registrado como crucial o problema do planejamento e da gestão regional, referido anteriormente. Existe um vazio nesta área com a transformação do órgão metropolitano em órgão estadual de desenvolvimento 


\section{Mapa 8 - Empreendimentos turísticos privados em implantação/previstos}

\section{Empregos diretos - Litoral Norte - janeiro 2008}

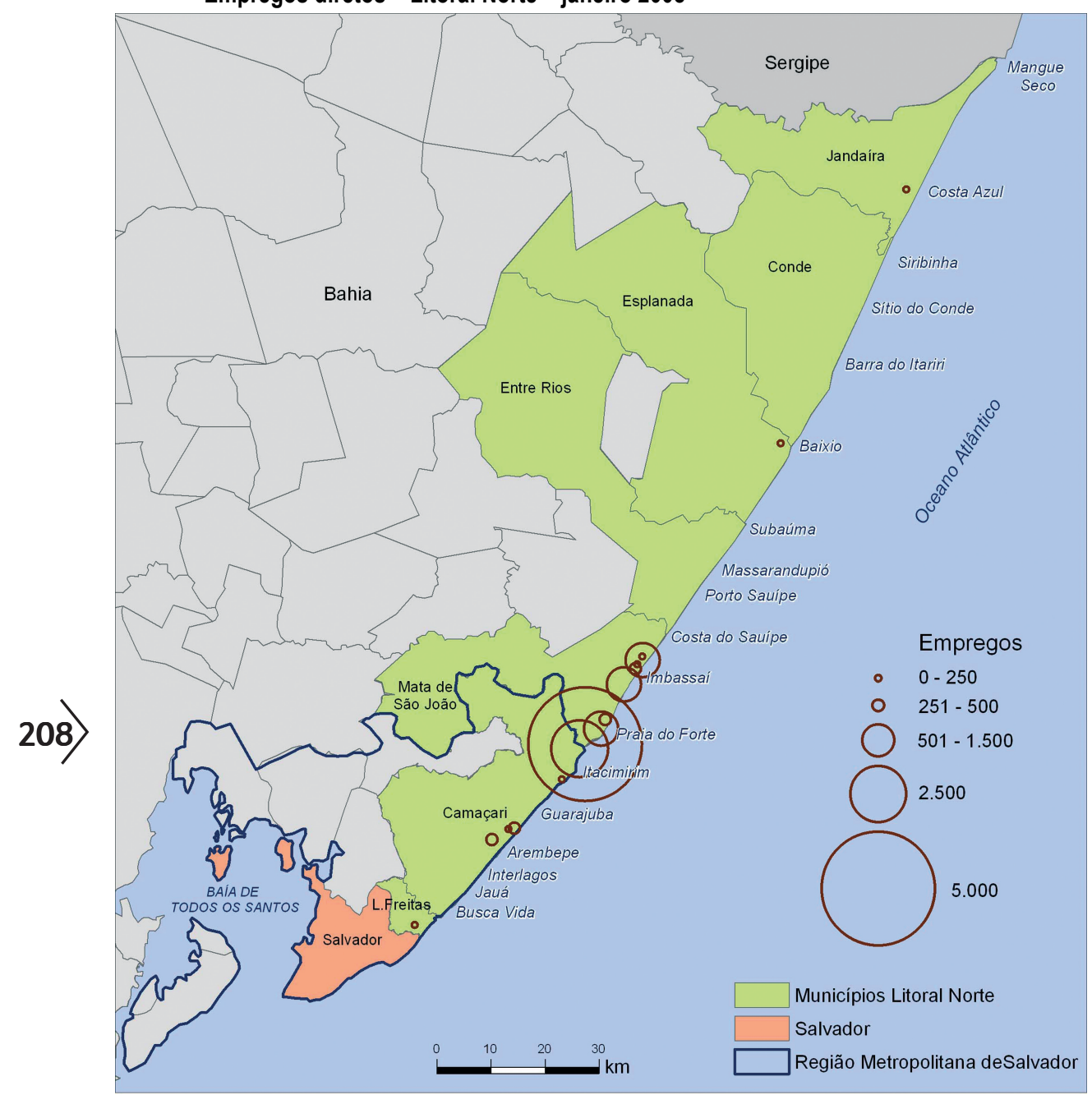

Fonte: SUINVEST - janeiro 2008

Elaboração: CARVALHO, S. S.; SILVA, B. C. N.

urbano. Há uma iniciativa relevante em curso que é a do Consórcio Intermunicipal da Costa dos Coqueiros, uma iniciativa pioneira (1999) da Fundação OndAzul, já atuando de acordo com a legislação federal sobre consórcios públicos (Lei 11.107, de 06/04/2005). É o primeiro consórcio intermunicipal da Bahia e do Brasil a funcionar com base nesta lei, segundo a Fundação OndAzul. Mas, apesar de sua importância, não preenche o vazio institucional no âmbito do Estado da Bahia. Este último tem sido eficiente na captação de investimentos e na implantação de uma infra-estrutura básica, mas pouco ativo no planejamento integrado e na gestão compartilhada. Por outro lado, é preciso buscar formas adequadas de interlocução, no planejamento e na gestão regional no litoral Norte da Bahia, com o município de Salvador, levando 


\section{Mapa 9 - Leitos de hotel - Região Metropolitana de Salvador e Litoral Norte - 2006}

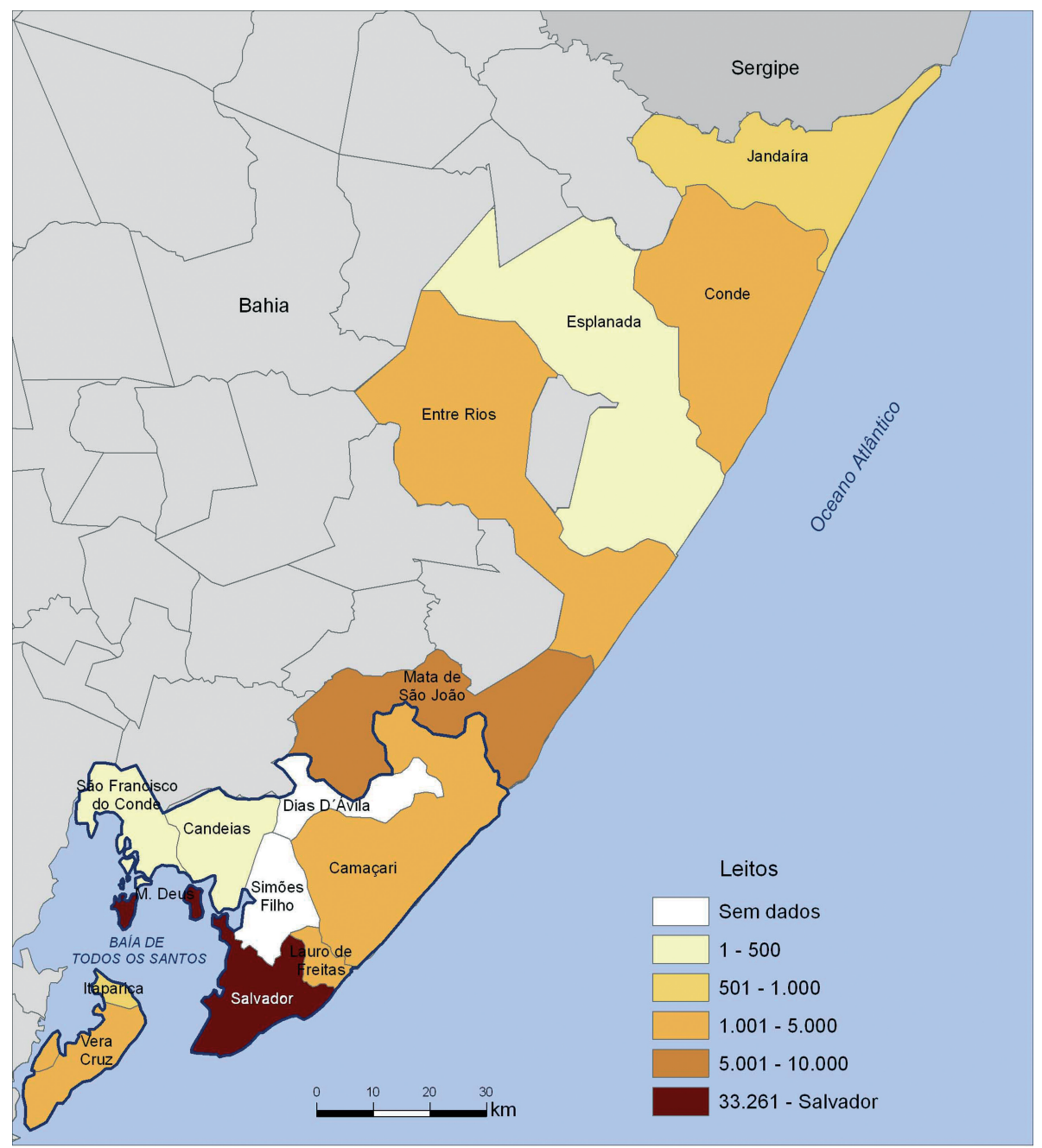

Fonte: BAHIATURSA - 2006

Elaboração: CARVALHO, S. S.; SILVA, B. C. N.

em conta a forte interação funcional entre a capital baiana e seu eixo Norte de expansão metropolitana, como foi demonstrado. A rigor, o que dá sentido a todo 0 dinamismo recente e atual no litoral Norte da Bahia, é o papel metropolitano de Salvador. Só com o fortalecimento do processo de planejamento e gestão regional, multi-setorial e multi-escalar, abrangente, aberto e participativo, será possível reverter a tendência atual de exclusão sócio-territorial no processo de expansão metropolitana no litoral Norte da Bahia, ou seja, reverter a opção preferencial pela produção de um território predominantemente de enclaves de luxo com repercussões bastante limitadas no contexto do desenvolvimento regional. 
METROPOLIZAÇÂO E TURISMO NO LITORAL NORTE DE SALVADOR: DE UM DESERTO...

\section{REFERÉNCIAS}

ALBAN, M. O novo enigma baiano, a questão urbano-regional e a alternativa de uma nova capital. In: XI ENCONTRO NACIONAL DA ASSOCIAÇÃO NACIONAL DE PÓS-GRADUAÇÂO E PESQUISA EM PLANEJAMENTO URBANO-REGIONAL, 2005, Salvador. Anais... Salvador: UFBA, 2005.

ASSIS, L. F. de. Turismo de segunda residência: a expressão espacial do fenômeno e as possibilidades de análise geográfica. Território, v.7, ns.11/13, p.107-122, jul. 2001/dez.2002.

AZEVEDO, T. de. O advento da Petrobrás no Recôncavo. In: BRANDÃO, M. Recôncavo da Bahia. Sociedade e economia em transição. Salvador: Fundação Casa de Jorge Armado, 1998. p.185-216.

BARICKMAN, B. J. Um contraponto baiano. Açúcar, fumo, mandioca e escravidão no Recôncavo, 17801860. Rio de Janeiro: Civilização Brasileira, 2003.

BRANDÃO, M. Posição socio-econômica de pequenos lavradores de subsistência na Bahia. In: III REUNIÃO BRASILEIRADE ANTROPOLOGIA, 1958, Recife. Anais...Recife, 1959. p.237-253.

. Relações agrárias em Camaçari. Tese de Livre Docência em Sociologia. Salvador: Faculdade de Filosofia e Ciências Humanas, 1975.

. Cidade e Recôncavo da Bahia. In: BRANDÃO, M. (Org.). Recôncavo da Bahia. Sociedade e Economia em transição. Salvador: Fundação Casa de Jorge Amado, 1998a. p.29-57.

. (Org.). Recôncavo da Bahia. Sociedade e Economia em transição. Salvador: Fundação Casa de Jorge Amado, 1998b.

BRANDÃO, P. M. C. Mudanças sócio-ambientais e desenvolvimento em Monte Gordo e Guarajuba/ Municípios de Camaçari/Bahia. Dissertação de Mestrado. Salvador: Mestrado em Geografia/UFBA, 2006.

BUTLER, R. W. The concept of a tourist area cycle of evolution: implications for management of resources.

Canadian Geographer, v.24, n.1, p.5-12, 1980.

CARVALHO, I. M. M. de; PEREIRA, G. C. Segregação sócio-espacial e dinâmica metropolitana. In: CARVALHO, I. M. M. de; PEREIRA, G. C. (Org.). Como anda Salvador. Salvador: EDUFBA, 2006. p. 83-109.

CHRISTALLER, W. Some considerations of tourism location in Europe: the peripherical regions underdeveloped countries - recreation areas. In: REGIONAL SCIENCE ASSOCIATION. XII LUND CONGRESS. Papers...1963. p.95-105.

CLAVAL, P. La logique des villes. Paris: Litec, 1981.

COSTA PINTO, L. de A. Recôncavo da Bahia: laboratório de uma experiência humana. Rio de Janeiro: CLASCO, 1958.

GOMES, L. Praia do Forte, BA: o paraíso e suas contradições. In: RODRIGUES, A. B. (Org.). Turismo, modernidade, globalização. São Paulo: Hucitec, 1997. p.172-184.

GUIA QUATRO RODAS. Brasil 2007. São Paulo: Abril, 2007.

. Brasil 2007. São Paulo: Abril, 2007.

GUIMARÃES, M. T. Arembepe: um estudo do desenvolvimento local. Dissertação de Mestrado. Salvador: Universidade Salvador/Programa de Pós-graduação em Desenvolvimento Regional e Urbano, 2007.

HOTELARIA. Salvador ganha primeiro all inclusive. A Tarde, Salvador, 28 fev.2008. Caderno Turismo, p.6. KRIPPENDORF, J. Die Landschaftsfresser. Tourismus und Erholungslandschaft - Verderben oder Segen? Bern: Verlag Forschungsinstitut für Fremdenverkehr der Universität Bern, 1975.

. Sociologia do turismo. Para uma nova compreensão do lazer e das viagens. São Paulo: Aleph,

2001.

LUNDGREN, J. O. J. On access to recreational lands in dynamic metropolitan hinterlands. Tourist Review, v.29, n.4, p.124-131, 1974. 
MATTEDI, M. R. M. Espaço e sociedade na Área de Proteção Ambiental do Litoral Norte da Bahia. Revista de Desenvolvimento Econômico, Salvador, v.3, n.5, p.104-112, dez.2001.

Sociedade e meio ambiente no litoral Norte da Bahia: transição para a (in)sustentabilidade.

Diploma de Estudos Aprofundados. Salvador/Barcelona: Universidade Salvador e Universidade Barcelona, 2002.

MONBEIG, P. Possibilidades de desenvolvimento das culturas alimentares ao Norte do município de Salvador. Boletim Baiano de Geografia, Salvador, UFBA, n.8, p.21-25, 1965.

MULLINS, P. Tourism urbanization. International Journal of Urban and Regional Research, v.15, n.3, p.326342, 1991.

OLIVEIRA, A. M. de. O Estado da Bahia e sua futura capital. Revista Brasileira dos Municípios, Rio de Janeiro, v.4, n.15, p.359-361, jul./set.1951.

OLIVEIRA, F. Elegia para uma re(li)gião. Rio de Janeiro: Paz e Terra, 1977.

A metamorfose do arribaçã: fundo público e regulação autoritária na expansão econômica do Nordeste. Novos Estudos, CEBRAP. São Paulo, n.27, p.67-92, 1990.

OLIVEIRA, R. de. Hotelaria. Sol Meliá investe US\$ 120 milhões. Gazeta Mercantil, São Paulo, 23 jan. 2008. p. C6

REIS, N. G. Notas sobre urbanização dispersa e novas formas de tecido urbano. São Paulo: Via das Artes, 2006.

SANTANA, E. A. Itaparica, do auge à decadência: a trajetória da primeira estância hidrotermal da Bahia. Dissertação de Mestrado. Salvador: Mestrado em Geografia da UFBA.

SANTOS, M. Devemos transferir a capital da Bahia? Revista Brasileira dos Municípios, Rio de Janeiro, v.11, n.43/44, p.155-156, jul./dez.1958. jul./dez.1959.

Salvador e o deserto. Revista Brasileira dos Municípios, Rio de Janeiro, v.12, n.47/48, p. 127-128,

.; SILVEIRA, M. C. O Brasil. Território e sociedade no início do século XXI. Rio de Janeiro: Record, 2001.

SASAKI, K. M. M. e. Turismo e sustentabilidade: a experiência do artesanato de palha de Porto Sauípe-BA. Salvador: Sathyarte/Fapesb, 2006.

SILVA, S. B. de M. e. Metropolização e raízes da periferização turística. Turismo em Análise, USP, v.7, n.2, p.7-16, 1996a.

. Geografia, turismo e crescimento: o exemplo do Estado da Bahia. In: RODRIGUES, A. A. B. (Org.). Turismo e Geografia: reflexões teóricas e enfoques regionais. São Paulo: Hucitec, 1996b. p.122-143.

Turismo e urbanização. In: RODRIGUES, A. B. Turismo modernidade, globalização. São Paulo: Hucitec, 1997. p.161-171.

.; SILVA, B. C. N. Desequilíbrios regionais e municipais no Estado da Bahia: uma análise dos padrões recentes. In: VIDAL, F. (Org.). Desenvolvimento regional: análises do Nordeste e da Bahia. Salvador: SEI/SEPLAN, 2006. p.95-111.

SOBRAL, L. E. S. O paraíso continuará aqui? Arembepe: análise dos cenários projetados. Diploma de Estudos Aprofundados. Salvador/Barcelona: Universidade Salvador e Universidade de Barcelona, 2002.

SOUZA, J. G. Camaçari: as duas faces da moeda: crescimento econômico $\mathrm{x}$ desenvolvimento social. Salvador: Universidade Salvador/Programa de Pós-graduação em Desenvolvimento Regional e Urbano, 2006.

SPÍNOLA, C. de A. O turismo como fator de desenvolvimento sócio-econômico - o impacto da atividade turística na Praia do Forte. Dissertação de Mestrado. Salvador: Escola de Administração da UFBA, 1996.

VASCONCELOS, L. Gringos avançam no litoral. A Tarde, Salvador, 24 mar.2008. p.2 



\title{
COOPERAÇÃO E COORDENAÇÃO NA REGIÃO METROPOLITANA DE SALVADOR: O CONTEXTO INSTITUCIONAL'
}

\author{
Celina Souza*
}

\section{INTRODUÇÃO}

As regiões metropolitanas das grandes cidades dos países em desenvolvimento são caracterizadas, do ponto de vista político, institucional e administrativo, como espaços territoriais onde ações cooperativas e de coordenação não foram constituídas ao longo do processo de metropolização. Se as grandes metrópoles são responsáveis pela geração de parcela expressiva da riqueza estadual e muitas vezes nacional, seu dinamismo e seus problemas extrapolam os limites formais municipais. No entanto, mecanismos de cooperação, de coordenação, de articulação, de relações intergovernamentais e de gestão do território, os quais compõem o que neste texto se denomina de governança metropolitana, quando existentes, ainda operam nos moldes dos períodos iniciais da urbanização, quando as responsabilidades espaciais e funcionais entre as esferas de governo eram mais claramente demarcadas, o que permitia que as instâncias governamentais atuassem de forma vertical, piramidal e hierárquica. Ou seja, a passagem de nível estratégico e atuação das metrópoles, do local para o urbano ou metropolitano, ainda não ocorreu na maioria das grandes cidades dos países em desenvolvimento. ${ }^{2}$

\footnotetext{
1 Versão atualizada para a 2a. edição de "Como Anda Salvador". Parte das análises e dados deste capítulo são uma síntese atualizada de outros trabalhos da autora sobre o tema. Ver Souza (2005a; 2005b; 2004; 2003; 1999; 1990).

** Ph.D em Ciência Política pela London School of Economics and Political Science (LSE) e pesquisadora do Centro de Recursos Humanos (CRH) da UFBA.

${ }^{2}$ Sobre este ponto, ver Stren (2003).
} 
No caso do Brasil, as primeiras experiências voltadas para a institucionalização das regiões metropolitanas (RMs) foram de iniciativa do regime militar, que as concebeu de acordo com os próprios objetivos do regime, ou seja, centralização e controle do território por parte do governo federal, que também caracterizou o desenho e a gestão das demais políticas públicas daquele período. Como argumentado anteriormente (Souza, 1985), o desenho institucional que guiou os primórdios da gestão metropolitana no Brasil deu ao governo federal grande domínio sobre os territórios mais dinâmicos do país, tanto do ponto de vista econômico como político. Desse desenho resultou a conformação da governança metropolitana dependente de recursos e de decisões federais, limitando a autonomia das esferas subnacionais, notadamente dos municípios que as integravam, desconsiderando aspectos fundamentais das relações intergovernamentais e excluindo a possibilidade de construção de mecanismos de cooperação e dificultando a coordenação. ${ }^{3}$

No caso da Região Metropolitana de Salvador (RMS), as questões relacionadas à cooperação e à coordenação não se colocam como exceção frente às demais regiões metropolitanas (RMs) do Brasil, ainda que apresentem algumas especificidades. Isso porque na maioria das RMs brasileiras diversas configurações políticas, tributárias, legais e administrativas atuam, simultaneamente, no sentido de constranger a cooperação entre os municípios metropolitanos e entre estes e o governo do estado (relações intergovernamentais), assim como no interior do próprio governo estadual (relações intragovernamentais).

Este texto mostra que a maioria das RMs brasileiras, inclusive a de Salvador, ainda não contam com mecanismos capazes de incorporar formas cooperativas e/ou mecanismos de coordenação para a formulação e a gestão de políticas públicas com recorte metropolitano, gerando um vazio institucional no que se refere à governança metropolitana. Constrangimentos de ordem tributária e institucional, aliados ao legado deixado pelo período militar, bloqueiam as possibilidades de criação de mecanismos cooperativos e de coordenação dos territórios metropolitanos. Ademais, com o fim do período autoritário, do qual resultou a mudança de regime político e o deslocamento da governança metropolitana da esfera federal para a estadual, o equacionamento de tais constrangimentos não estava (e continua não estando) na agenda dos que detêm poder decisório.

Muitos advogam que o vazio político, financeiro e institucional das RMs brasileiras tem impacto negativo sobre as políticas públicas, sobre a prestação de serviços nos territórios metropolitanos e sobre a construção de uma visão de futuro para os espaços territoriais economicamente mais dinâmicos e socialmente mais complexos do país. Um dos efeitos desse vazio pode ser sentido na dificuldade de se criar mecanismos de cooperação entre entes governamentais em um sistema federativo onde esses entes gozam de relativa autonomia para decidir sobre questões

\footnotetext{
${ }^{3}$ Como mostram várias pesquisas, mesmo nos sistemas mais coercitivos existem poderosos limites ao exercício do comando (Etzioni, 1965). No caso brasileiro, autores como Medeiros (1986) e Souza (1997) demonstraram os limites do regime autoritário na sua atuação nos estados.
} 
que afetam seu território. Outro efeito diz respeito à ambigüidade ou omissão dos organismos estaduais em relação às funções metropolitanas. Apesar desse vazio, 0 tema metropolitano (ou das grandes cidades), silenciado nos anos 90, começa, lentamente, a ressurgir na agenda pública, embora ainda restrito a fóruns acadêmicos e técnicos. Questões como violência urbana, pobreza, falta de infra-estrutura nas áreas mais pobres, desemprego, habitação e transporte público, que em geral ultrapassam os limites territoriais municipais, são constantemente debatidas em diversos fóruns, embora não necessariamente associadas à busca de novas formas de governança metropolitana ou à criação de mecanismos de cooperação intra ou intergovernamental.

Este trabalho está dividido em quatro partes. A primeira mapeia algumas abordagens teóricas relacionadas à cooperação e à coordenação nos territórios metropolitanos à luz da teoria da ação coletiva. A segunda e a terceira discutem os constrangimentos institucionais existentes nas grandes cidades do mundo em desenvolvimento e no Brasil para a criação de mecanismos cooperativos e de coordenação intra e intergovernamental. A quarta parte discute as especificidades da Região Metropolitana de Salvador do ponto de vista político-institucional. Porque do ponto de vista institucional a Região Metropolitana de Salvador não apresenta grandes distinções em relação às demais regiões metropolitanas do Brasil e daquelas do mundo em desenvolvimento, as análises de todas as seções são a ela aplicáveis.

\section{COOPERAÇÃO, COORDENAÇÃO E AÇÃO COLETIVA EM TERRITÓRIOS METROPOLITANOS: algumas considerações teóricas}

Ações voltadas para a articulação de entes governamentais podem ser genericamente divididas em ações de cooperação e de coordenação. A distinção é importante dado que cada uma dessas ações requer desenhos institucionais diversos, embora ambas impliquem em barganha e negociação. A cooperação tende a manter a autonomia dos entes que dela participam e a coordenação tende a centralizar decisões, por requerer medidas "de cima para baixo". No entanto, cooperação e coordenação podem ocorrer simultaneamente. $O$ que varia é a ênfase dada a cada uma.

Do ponto de vista metropolitano, mecanismos de cooperação e de coordenação requerem a negociação de preferências diversas entre um mosaico de atores e de agências autônomos em relação à fonte de autoridade e que atuam simultaneamente no mesmo espaço territorial, incluindo, portanto, agências públicas, societais, semipúblicas e privadas. Fazer com que esses atores e agências cooperem no território metropolitano ou que legitimem os entes envolvidos na coordenação, gera o que é chamado de problema de ação coletiva. ${ }^{4}$ Com inúmeros atores e agências

${ }^{4}$ Como se sabe, o trabalho fundador sobre ação coletiva e a importância de incentivos seletivos foi o de Olson (1965). Desenvolvida na área da economia, a teoria vem sendo testada em pesquisas de outras disciplinas. 
envolvidos, os problemas de ação coletiva são inerentes a toda ação complexa, incluindo a gestão metropolitana. Isso porque ações metropolitanas requerem a combinação de estratégias onde várias políticas de desenvolvimento econômico, social e de infra-estrutura urbana - habitação, saneamento, educação, saúde, segurança pública, emprego e renda etc. - são desenhadas e implementadas simultaneamente por diferentes agentes governamentais e não-governamentais que gozam de autonomia relativa.

Formatos de gestão ou políticas públicas que demandam a cooperação de muitos atores e agências e/ou sua coordenação constituem, portanto, um problema de ação coletiva de um grande grupo. Como aponta a literatura, a cooperação nos grandes grupos tende a ter custos elevados e implica a construção de consensos entre os diversos objetivos dos órgãos de diferentes níveis de governo e dos diferentes grupos de interesses para que suas ações e recursos convirjam simultaneamente para uma dada decisão.

A literatura mostra ainda que os problemas de ação coletiva são mais facilmente resolvidos nos pequenos grupos, onde a criação de incentivos para a cooperação e a coordenação, ou seja, as recompensas pela cooperação e as sanções pela não-cooperação, é menos complexa. Isso porque os pequenos grupos podem ser regidos por regras de reciprocidade, confiança e informalidade na aplicação de recompensas e sanções. Da mesma forma, experiências prévias de mobilização e ação entre membros do grupo, assim como a existência de homogeneidade política ou ideológica, contribui para aumentar a probabilidade de cooperação nos pequenos grupos e, portanto, para a provisão de bens coletivos de forma cooperativa.

A literatura especializada tem, cada vez mais, dedicado espaço ao debate sobre o papel do desenho institucional na ação coletiva, ou seja, sobre a construção de regras que incentivem atores e agências à cooperação para o objetivo da produção do bem comum ou coletivo, ou, de forma mais direta e em consonância com os objetivos deste trabalho, regras para se alcançar os objetivos de uma governança metropolitana baseada na cooperação (mais horizontal) e/ou na coordenação (mais vertical). Isso porque a cooperação, por não ser intrinsecamente voluntária, e a coordenação, por requerer legitimidade, só ocorrerão na vigência de uma estrutura de incentivos que torne possivel superar a inércia inicial dos atores e das agências, minimizar conflitos de interesses e de preferências e a tendência à não-cooperação.

Outra questão relacionada à cooperação e à coordenação e que tem também sido objeto de várias pesquisas diz respeito a como criar incentivos para a realização do "interesse comum", característica constitucional das RMs no Brasil. Tanto do ponto de vista teórico como empírico, reconhece-se que os incentivos à cooperação e à coordenação podem ser não somente negativos (sanções) e positivos (recompensas), mas também seletivos. Isso significa que esses incentivos não operam de forma indiscriminada sobre o conjunto de atores e agências, mas de forma seletiva, ou seja, diferentes atores e agências requerem incentivos diferentes. Um exemplo da importância dos incentivos seletivos para operacionalização de políticas públicas pode 
ser encontrado nas políticas federais de educação e saúde hoje existentes no Brasil. Ambas as políticas foram concebidas como um sistema complexo de relações intergovernamentais baseado em recompensas e sanções e combinam mecanismos de coordenação com mecanismos de cooperação. Apesar do governo federal ter tomado várias iniciativas estimulando a descentralização da maioria das políticas sociais, inclusive patrocinando novas legislações, muitas falharam porque o desenho institucional não contemplou nem a injeção de recursos novos, que é o caso da saúde, nem a possibilidade de perda relativa de recursos, que é o caso da educação. Assim, em contraste com o que aconteceu com as políticas federais de descentralização das atividades de saneamento, habitação e assistência social, os governos subnacionais responderam positivamente aos incentivos à descentralização da saúde e da educação. ${ }^{5}$ A resposta positiva à municipalização da saúde pode ser creditada à injeção de recursos adicionais nos cofres locais e à da educação por penalizar o município que não aumentar as matrículas nas escolas municipais, ao tempo em que também injeta mais recursos nas comunidades locais mais pobres, dado que a política suplementa o salário dos professores nos municípios mais carentes.

Em síntese, a construção de mecanismos que incentivem a cooperação e que criem as condições para a coordenação nas RMs teria o objetivo de romper 0 isolamento político, institucional e administrativo que tem caracterizado a atuação de agências e atores que operam no território metropolitano, em especial entre agências governamentais.

\section{COOPERAÇÃO E COORDENAÇÃO NAS RMS E SEUS PRINCIPAIS CONSTRANGIMENTOS}

As regiões metropolitanas dos países em desenvolvimento são caracterizadas, do ponto de vista político, institucional e administrativo, como espaços territoriais onde ações cooperativas e de coordenação não foram constituídas ao longo dos seus acelerados processos de metropolização. Esta seção busca apontar as principais conseqüências da ausência de cooperação e de coordenação nas RMs, investigando, também, por que a construção de uma governança metropolitana, que substitua a dinâmica da competição pela dinâmica da cooperação, é constrangida. Ou seja, quais são os principais entraves institucionais à governança metropolitana e por que eles existem?

Não é peculiaridade das RMs brasileiras a ausência de mecanismos que incentivem a cooperação metropolitana ou que dificultem a coordenação. A literatura mostra que nas grandes cidades do mundo em desenvolvimento seu crescimento, tanto espacial como econômico, não foi acompanhado da necessária infraestrutura, gerando problemas de deseconomias e grandes lacunas espaciais no acesso a bens

${ }^{5}$ Sobre este ponto, ver Arretche (2000). 
e serviços e nos investimentos públicos e privados, os quais não são distribuídos de forma minimamente eqüitativa entre as diferentes partes do território. Essas características estão presentes tanto no território metropolitano como no interior de um mesmo município.

Como mencionado acima, se, por um lado, as grandes cidades do mundo em desenvolvimento são responsáveis pela geração de parcela significativa da riqueza dos territórios onde estão situadas, no entanto, tanto sua riqueza como seus problemas extrapolam os limites formais municipais. Por outro lado, os mecanismos de cooperação, de coordenação, de articulação, de relações intergovernamentais e de gestão do território ainda operam nos moldes dos períodos iniciais da urbanização. Tais características mostram a ausência de reorientações e até de reconceituações dos sistemas de governo, de formulação de políticas públicas e de gestão das grandes cidades.

Reorientações e reconceituações desse tipo implicam na passagem de nível estratégico de atuação, ou seja, do local para o urbano ou metropolitano. 0 fato de que essa passagem ainda estar por ser feita gera alguns paradoxos. O primeiro é que as grandes cidades e as RMs passam a ter que gerar capacidades para encaminhar soluções relativas a problemas que ocorrem no nível mais micro possivel e para funções que vão da zeladoria urbana ao planejamento estratégico, ao tempo em que têm que operar em escalas bem maiores, que vão da metropolitana à estadual, nacional e global. $O$ segundo decorre do fato de que existem nessas regiões grandes articulações na circulação das pessoas, bens, mercadorias, produtos e capital, mas esses fluxos estão desarticulados do ponto de vista político, institucional, administrativo e também em relação às informações. ${ }^{6}$ Este paradoxo indica que os fatores socioeconômicos caminham sempre de forma mais rápida do que os políticos, institucionais e administrativos. O terceiro é que, embora o fluxo de pessoas, mercadorias e capitais entre os municípios que compõem uma RM sejam intensos, a população desses municípios não constituiu um senso de identidade regional, de pertencimento a uma região, capaz de gerar pressão social favorável a uma gestão metropolitana ou a uma estratégia cooperativa e coordenada das ações das agências e dos atores que operam na RM. O quarto é que, com o advento da globalização, que, em muitos países em desenvolvimento ocorreu pari passu com processos de redemocratização e de descentralização, espera-se dos governos dessas grandes cidades que operem na velocidade e na eficiência requeridas pelo mundo dos negócios, o que implica em rapidez e número de participantes do processo decisório limitado, ao tempo em que se espera que os governos atendam às demandas de diferentes grupos sociais, o que requer a incorporação ao processo decisório de um número maior de participantes com interesses divergentes. Tal paradoxo implica atuar em tempos e espaços diferenciados e com estratégias de negociação de interesses,

\footnotetext{
${ }^{6}$ A produção e análise de informações, ou os dados necessários para uma visão estratégica das RMs, é fator condicionador importante para a elaboração institucional da região, além, é claro, de ser fundamental para o processo decisório e para a construção de estratégias de desenvolvimento social e econômico.
} 
preferências e conflitos também diferenciadas. Por fim, em muitas RMs, enquanto algumas áreas das cidades contam com infraestrutura e serviços adequados, assim como com atividades econômicas geradoras de renda e riqueza, existem grandes espaços que permanecem em uma espécie de vazio governamental e econômico.

Além das características acima mapeadas, existem também países do mundo em desenvolvimento que adotaram, a partir do final dos anos 80 , políticas descentralizadas. Este é o caso, por exemplo, do Brasil. Políticas descentralizadas geram, em geral, fragmentação e desarticulação das ações das agências e dos atores, particularmente dos governos. A descentralização, em geral, não foi acompanhada da construção de mecanismos indutores da cooperação, da coordenação e da articulação entre diferentes unidades territoriais requeridas para uma gestão metropolitana.

Os paradoxos acima mencionados mostram a inexistência de desenhos institucionais, ou seja, de regras formais e informais capazes de enfrentar os constrangimentos políticos, institucionais e administrativos às ações compartilhadas nas regiões metropolitanas dos países em desenvolvimento. No caso particular do Brasil, instituições voltadas para esse fim tenderiam a limitar o papel das estruturas políticas, institucionais e administrativas descentralizadas hoje existentes. Ademais, iniciativas nesse sentido só se materializaram no Brasil quando comandadas (ou coordenadas) pela esfera federal de governo, que é o caso das políticas descentralizadas de educação e saúde.

Diante do exposto, pode-se argumentar que as grandes cidades do mundo em desenvolvimento carecem de capacidades cooperativas e de coordenação para enfrentar as principais dimensões de uma governança metropolitana. Entre essas dimensões estão a de gerar estratégias de desenvolvimento regional e de enfrentamento articulado das desigualdades sociais e de infraestrutura, de financiamento das ações metropolitanas e de distribuição e alocação de poder e autoridade, não só entre entes governamentais, mas também entre os demais participantes da cena metropolitana. No entanto, formas institucionalizadas de governança metropolitana não significam, necessariamente, a constituição de um governo metropolitano nem de uma instância formalmente instituída pelos governos com autoridade sobre o território metropolitano.

A superação dos constrangimentos acima mencionados requer a compreensão de que problemas complexos não têm soluções técnicas e políticas claras ou fáceis devido, entre outros fatores, à multiplicidade de interesses conflitantes envolvidos e ao fato de que questões complexas sempre terão soluções sub-ótimas.

\section{COOPERAÇÃO E COORDENAÇÃO NAS RMS BRASILEIRAS}

Diversas configurações políticas, tributárias, legais e administrativas atuam no sentido de constranger a cooperação e a coordenação nas RMs, as quais também se aplicam à Região Metropolitana de Salvador (RMS). 
No caso das RMs brasileiras em geral, os seguintes constrangimentos podem ser apontados. $O$ primeiro diz respeito ao sistema federativo. Isto porque não só esse tipo de divisão territorial de governo é sempre mais descentralizado do que 0 sistema unitário, mas também porque no Brasil existe grande autonomia dos municípios vis-à-vis os estados, o que acirra o conflito entre os que governam as grandes cidades e os que governam o estado. Na ausência de mecanismos de relações intergovernamentais, de cooperação e de resolução de conflitos, ações compartilhadas só são viabilizadas na ocorrência de interferência federal, dadas as características altamente competitivas do federalismo brasileiro, aliado ao fato de não ter sido gerado mecanismos de cooperação inter ou intragovernamentais. ${ }^{7}$ Conflitos entre estados e municípios, em especial entre as capitais e os governos estaduais, são freqüentes e assumem diferentes formatos. Um exemplo é o conflito relacionado à titularidade dos serviços em rede, que gera controvérsias do ponto de vista jurídico e político. 0 caso dos sistemas de água e esgoto é o mais claro.

Ainda em relação ao sistema federativo, o Brasil optou por um modelo de federalismo baseado na simetria de competências (federalismo simétrico), ou seja, toda esfera do mesmo nível de governo tem competências iguais, o que faz com que as competências de um município muito pequeno sejam iguais às de grandes cidades e capitais estaduais. Tal característica constrange a autonomia decisória de municípios que detêm maiores e mais complexas capacidades técnicas e financeiras.

O federalismo por si só e enquanto instituição não é responsável pelo acirramento de conflitos intergovernamentais e pela ausência de mecanismos de cooperação. Contudo, no caso do Brasil os conflitos inerentes ao formato federativo de governo não contam com canais de intermediação de interesses ou com mecanismos de relações intergovernamentais formais ou informais indutores do diálogo e da cooperação entre os entes federados.

Tensões nas relações intergovernamentais são típicas da complexidade e do crescimento das tarefas públicas que foram sendo delegadas aos governos ao longo do tempo. Essas tensões, todavia, são agravadas em situações onde as capacidades dos níveis de governo são muito desiguais ou quando as instâncias na ponta das relações intergovernamentais são muito frágeis, como acontece em várias RMs brasileiras e particularmente na RMS. Como nos ensina Pressman (1975, p. 106), as relações intergovernamentais geram, sempre, "doadores" e "receptores", os quais dependem um do outro e onde nenhum tem o completo controle sobre a ação. Daí a importância dos instrumentos de apoio mútuo, construídos a partir de negociações que vão se desenvolver de forma parcialmente cooperativa e parcialmente antagônica, mas sempre mutuamente dependentes.

\footnotetext{
${ }^{7}$ Pesquisa realizada pela Universidade Pompeu Fabru, de Barcelona mapeou os principais instrumentos de relações intergovernamentais em uso em vários países federais. Ainda pouco utilizados no Brasil, esses instrumentos são relativamente comuns na Alemanha, Canadá, Austrália, Suiça e EUA. De acordo com essa pesquisa, Brasil e Argentina aparecem como os países federais pesquisados onde os instrumentos de relações intergovernamentais são menos utilizados. Ver, a respeito, Agranoff (2003).
} 
O segundo grande constrangimento resulta do sistema tributário. Aausência de um sistema tributário voltado para uma melhor equalização fiscal entre os municípios estimula 0 acirramento da competição. Exemplo dessa competição é a guerra fiscal dos municípios metropolitanos contra as capitais em torno das alíquotas do ISS (Imposto sobre Serviços). ${ }^{8}$ Essa competição foi apenas parcialmente equacionada através de legislação federal sobre a matéria, mas continua longe de ser resolvida. ${ }^{9}$ Ademais, a Constituição brasileira não prevê incentivos tributários para que os municípios cumpram diferentes papéis no território metropolitano. Por fim, mudanças nas regras tributárias têm se mostrado politicamente complexas porque essas regras são, em geral, constitucionalizadas, o que exige emenda constitucional ou maioria qualificada.

O terceiro constrangimento decorre da decisão de se adotar e aprofundar a descentralização. Como mostram vários trabalhos, houve uma intensa mobilização de atores e instituições em defesa da descentralização durante a Constituinte, dando os passos iniciais para a municipalização das políticas sociais com participação comunitária. No entanto, inexistem hoje atores e instituições defendendo formas compartilhadas e coordenadas de formulação de políticas e de gestão do território metropolitano, além da comunidade de especialistas. Ademais, a descentralização passou a ser vista no Brasil como uma política virtuosa, o que gera o seguinte paradoxo: a governança metropolitana requerer alguma forma de coordenação, ou mecanismos mais centralizados de planejamento e de gestão, o que constrangeria, obviamente, os objetivos da descentralização.

Por fim, existe ainda um constrangimento relacionado à trajetória da institucionalização das RMs no Brasil, dado que a mesma foi associada a formas autoritárias de gestão do território por ter sido introduzida em 1973, no auge do regime militar. Como conseqüência, o desenho institucional das regiões metropolitanas foi pautado na dependência de recursos e decisões federais e na centralização, constrangendo a autonomia das esferas subnacionais, notadamente dos municípios que as integravam, e desconsiderando aspectos fundamentais das relações intergovernamentais. Como mostra a literatura, constrangimentos de origem constitutiva dificultam mudanças na rota das políticas públicas dado que as escolhas institucionais feitas no passado tendem a influenciar escolhas futuras, uma vez que mudanças em relação ao caminho (rota) adotado anteriormente têm custos elevados. ${ }^{10}$

$\mathrm{Na}$ tentativa de lidar com essas questões, a Constituição Federal de 1988

${ }^{8}$ No caso da RMS, a competição em torno do ISS ocorre principalmente entre Salvador e Lauro de Freitas.

${ }^{9}$ Foi promulgada a Emenda Constitucional no. 37/2002, dando ao Executivo federal competência para, através de lei complementar, fixar alíquotas máximas e mínimas para o ISS e para "regular a forma e as condições como isenções, incentivos e benefícios fiscais serão concedidos e revogados". A lei complementar n. 116 regulamentou a emenda constitucional e foi promulgada em 31/7/2003.

${ }^{10}$ Para uma análise desse ponto a partir do conceito de path dependency (rota dependente), ver Souza (2003; 2005a). 
incorporou um capitulo sobre política urbana como resposta às pressões do movimento em prol da reforma urbana. Contudo, esse esforço limitou-se à constitucionalização de alguns dispositivos jurídicos e urbanísticos de regulação do território, não incorporando formas de gestão urbano-metropolitana baseadas em mecanismos cooperativos e/ou de coordenação voltados para o enfrentamento dos problemas das metrópoles. Na verdade, a questão metropolitana recebeu dos constituintes federais pouca atenção, sendo remetida à decisão dos constituintes estaduais, os quais também não concederam prioridade ao tema.

No período pós-transição democrática e pós-Constituinte, a agenda política esteve voltada para a efetiva implementação da descentralização e da participação societal na gestão das políticas sociais, sem que a chamada questão metropolitana estivesse nessa agenda. Mais recentemente, busca-se introduzi-la na agenda política, ao tempo em que se inicia 0 debate sobre formas institucionais para 0 atendimento dos cada vez mais complexos problemas das metrópoles brasileiras. No entanto, tentativas nessa área continuam restritas à comunidade de especialistas.

Por fim, outra questão importante da cooperação e da coordenação nas políticas públicas brasileiras é que passou a existir um consenso de que 0 encaminhamento de alternativas para a formulação de políticas e para a gestão governamental requer a participação de vários stakeholders e não apenas dos governos. Isso implica na introdução do conceito mais estrito de governança, que compreende os mecanismos, os processos e as instituições através dos quais os cidadãos e os grupos articulam seus interesses, exercitam seus direitos, cumprem suas obrigações e intermedeiam suas diferenças. ${ }^{11}$ No entanto, também parece claro que, no caso das grandes cidades, existe a necessidade de reter o papel de comando e de liderança dos governos, com capacidade para coordenar a política, os interesses e as preferências de diferentes atores, bem como de implementar políticas públicas. A despeito da popularidade do uso desse conceito de governança, é importante ressaltar que o mesmo advém de um modelo de democracia liberal, no qual se pressupõe a existência de cidadãos bem informados, protegidos por regras universais, legais e institucionais, os quais fazem escolhas periódicas sobre o curso das ações governamentais. Se esse conceito mais restrito de governança conquistou coração e mentes dos governantes brasileiros, por outro lado o papel a ser desempenhado pelos próprios governos permanece obscuro ou ambíguo.

Além dos constrangimentos delineados acima, as experiências de cooperação e coordenação intra e intergovernamental têm sido escassas no Brasil, com exceção do crescimento acelerado dos consócios intermunicipais. ${ }^{12} \mathrm{O}$ exemplo

${ }^{11}$ No Brasil, esse conceito de governança foi transformado em mandamento legal, principalmente no que se refere às políticas sociais que ocorrem nos territórios locais, pela exigência da constituição de conselhos que contam com a participação dos governos locais, dos usuários dos serviços e de representantes dos grupos de interesse.

${ }^{12}$ Segundo o IBGE, existiam, em 2001, 1.969 consórcios municipais de saúde. Áreas como meio ambiente e desenvolvimento econômico também têm sido objeto de criação de consórcios. Os consórcios foram 
mais dramático da falta de cooperação e de coordenação metropolitana é encontrado no nível de vulnerabilidade social dos que vivem nos limites municipais, sempre mais alto do que nos demais distritos pobres da cidade. ${ }^{13}$

Para completar, a maioria das análises sobre o tema metropolitano no Brasil e na RMS focaliza, quase que exclusivamente, a ausência do governo federal e a relação entre a esfera estadual e as locais de governo, praticamente ignorando a questão sobre como o tema metropolitano é tratado no interior da estrutura dos governos estaduais. Essa questão é importante por duas razões. A primeira é que a competência para decidir sobre questões metropolitanas é dos estados. A segunda é que a tarefa de governar, em qualquer nível de governo, assumiu enorme complexidade. Essa complexidade vai desde a expansão e proliferação de órgãos públicos, todos com autonomia relativa, até a necessidade de se formar coalizões de governo entre diferentes partidos e grupos políticos, o que gera disputas dentro do mesmo governo. Aliado a esses fatores, existe também forte limitação financeira decorrente da expansão dos gastos dos governos com novas funções e das medidas de controle desses mesmos gastos promovidos pelos ajustes fiscais. Isso mostra que a discussão da questão metropolitana e a construção de políticas e de formas de governança não podem ignorar os problemas existentes no interior dos governos estaduais, questão sobre a qual as análises técnicas e acadêmicas têm, em geral, ignorado.

A despeito da ausência de cooperação e de ainda poucas experiências de coordenação, existiam, em 2000, 23 RMs institucionalizadas por legislações estaduais, de acordo com o IBGE. Institucionalizar significa, apenas, que esses estados mantiveram ou aprovaram legislações reconhecendo parcelas dos seus territórios como metropolitanos. Institucionalizar não significa, necessariamente, que nessas RMs a governança metropolitana esteja em operação.

regulamentados pela Lei Federal 11.107, de 11/04/05. A experiência dos consórcios, com partilha de provisão de serviços, recursos e pessoal, está hoje ainda mais disseminada, especialmente em municípios de médio porte. A maioria das experiências conta com apoio financeiro do estado e/ou do governo federal.

${ }^{13} \mathrm{O}$ caso da RM de São Paulo tem sido bastante estudado pelo CEM-CEBRAP. Vários levantamentos e análises sobre esse tema podem ser encontrados em www.centrodametropole.org.br. No caso da RMS, ver capítulos 2 a 6 desta edição. O Ministério das Cidades acaba de dar uma enorme contribuição ao tema através do estudo Precariedade no Brasil Urbano, realizado pelo CEM-CEBRAP. $O$ estudo estimou a presença, a localização e as características de moradores de assentamentos precários de 561 municípios, inclusive os das RMs. $O$ estudo encontrou uma população de cerca de 6 milhões de habitantes nessas condições, muito acima dos números estimados pelo IBGE. Pará, Amazonas, Ceará, Bahia e Amapá são os estados com maior população habitando aglomerados subnormais e assentamentos precários, com índices acima de 20\%. A RMS conta, nesse estudo, com $23,1 \%$ de domicílios em assentamentos precários ou subnormais, totalizando 709.353 pessoas. A síntese do estudo pode ser acessada em http://www.cidades.gov.br. Análises mais qualitativas sobre as condições sociais dos moradores metropolitanos vêm sendo produzidas pelo Observatório das Metrópoles. Ver, por exemplo, Ribeiro (2004). 


\section{RMS: principais constrangimentos das ações cooperativas e de coordenação}

Como mencionado acima, tanto do ponto de vista empírico como teórico as questões relacionadas à cooperação e à coordenação na Região Metropolitana de Salvador (RMS) não se colocam como uma exceção frente as RMs dos países do mundo em desenvolvimento nem das demais RMs brasileiras, ainda que apresentem algumas particularidades. Esta seção aborda as principais especificidades políticoinstitucionais da RMS que constrangem a cooperação não só entre o governo do estado e os municípios, mas também o papel coordenador do governo do estado.

Uma das especificidades político-institucionais da RMS é que a sua constituição aconteceu antes da institucionalização federal das RMs. A criação da entidade governamental com recorte pré-metropolitano ocorreu em 1967, com a instituição do Conselho de Desenvolvimento do Recôncavo (Conder). Sua finalidade era elaborar uma estratégia de desenvolvimento regional integrado para o Recôncavo, compreendendo 37 municípios. A abrangência dessa vasta área de jurisdição fundamentava-se no entendimento de que o desenvolvimento de Salvador e de sua área de influência associava-se ao desenvolvimento do Recôncavo, o qual seria responsável pelo dinamismo pretendido para o setor primário, visto então como a força motriz da região.

Com a crescente consolidação de atividades industriais na RMS e a concomitante decadência da atividade agrícola, o Recôncavo deixou de ser visto como prioritário para o desenvolvimento econômico da região. Assim, a área abrangida pela Conder foi reduzida, passando a ser composta por oito municípios considerados de "relevante interesse" porque integravam uma mesma comunidade econômica. Nesse mesmo período, o governo federal promulgou a Lei Complementar 14/73, instituindo nas principais capitais e nos municípios do seu entorno a figura da região metropolitana. $O$ estado da Bahia adaptou-se às novas determinações federais, formando os Conselhos Deliberativo e Consultivo da RMS, inicialmente presididos pelo secretário do Planejamento e, posteriormente, pelo governador do estado. Se, por um lado, a decisão de passar a presidência de tais conselhos ao governador funcionou como um reforço político para o planejamento metropolitano e para sua inserção na estrutura governamental, por outro, teve o efeito de acentuar a centralização do processo decisório da entidade metropolitana na esfera administrativa superior do estado.

Em 1974, o Conselho de Desenvolvimento do Recôncavo foi transformado em empresa pública vinculada à Secretaria do Planejamento, denominada Companhia de Desenvolvimento da Região Metropolitana de Salvador, mantendo a mesma sigla (Conder). Seu objetivo era "promover, coordenar, e executar a política de desenvolvimento formulada pelo Conselho Deliberativo da RMS".

Se a característica de empresa pública foi mantida ao longo dos anos e permanece até hoje, o modelo institucional, ou as regras formais e informais que 
regem a empresa, foi alvo de diversas mudanças. Em 1975, a Conder passou a ser subordinada ao governador. A intenção era conceder-lhe maior poder decisório, situando-a no mesmo nível hierárquico das secretarias de estado. Logo em seguida, a Conder retorna à estrutura da Secretaria do Planejamento, sob a justificativa de que um órgão de planejamento deveria estar vinculado à estrutura responsável pelo planejamento global do estado. Paradoxalmente, a partir dessa mudança a Conder deixou de limitar suas atividades ao planejamento, passando também a executar obras e a coordenar projetos, além de prestar assistência técnica aos municípios da RMS. Nesse dilema sobre a indefinição de sua função precípua - planejar e executar ou apenas planejar - reside um traço distintivo da entidade metropolitana da RMS em relação às demais entidades brasileiras, as quais, na sua totalidade, concentraram suas atuações no planejamento e na produção de informações.

Em 1998, retirou-se da Conder a exclusividade da gestão metropolitana. Ainda sob a mesma sigla, a Conder passou a ter jurisdição sobre todo o território estadual, com a denominação de Companhia de Desenvolvimento Urbano do Estado da Bahia e com o objetivo formal de "promover, coordenar e executar a política estadual de desenvolvimento urbano, metropolitano e habitacional do estado da Bahia". Em 1992, com a criação da Secretaria de Desenvolvimento Urbano (Sedur), a Conder passou a ser a ela vinculada. Embora a competência metropolitana seja formalmente restrita à Conder, a entrada de mais uma agência governamental na cena urbana pode indicar uma zona cinza de competências e atribuições.

Todas essas mudanças refletem o jogo de forças entre os atores envolvidos nas configurações políticas vigentes em cada época. Ao longo de sua trajetória, as mudanças institucionais, ou as regras formais e informais que regeram o papel da entidade metropolitana, derivaram do apoio político obtido por suas lideranças, em associação aos projetos políticos dos governantes estaduais, que sempre usaram a Conder como instrumento para atingir seus objetivos político-eleitorais. Muitas escolhas, todavia, notadamente as dos anos iniciais, também foram fruto de decisões externas à RMS e condicionadas ao cumprimento de leis federais editadas durante 0 período autoritário.

Após a redemocratização e até os dias atuais, a Conder continua sendo umas das exceções frente às demais entidades metropolitanas brasileiras, uma vez que ainda permanece ativa, mas perdendo sua abrangência eminentemente metropolitana. Isso se deve ao modo peculiar da trajetória da instituição, marcada por variáveis políticas, econômico-financeiras e técnicas, as quais influenciaram suas escolhas político-institucionais e seu desempenho.

No campo eminentemente político, pouco ainda se conhece sobre os processos que caracterizam a RMS. Pesquisa realizada em 1987 com elites da região mostrou que a RMS comportava a convivência de duas racionalidades políticas contraditórias: uma "velha" racionalidade agrária, em que predominavam as solicitações pessoais, como os pedidos de emprego e de auxílio financeiro; e uma "nova" racionalidade urbano-industrial, em que as demandas se aproximavam dos direitos 
de cidadania, como a luta por melhores serviços urbanos. A pesquisa concluiu que a RMS passava por uma transição sociopolítica, onde a modernização econômica e urbana não correspondia à redefinição das relações políticas e sociais (Medeiros e Souza, 1993. Pesquisa mais recente (Setzler, 2003), mas que apenas analisou os processos político-eleitorais de Salvador, também confirmou esse quadro.

Outro aspecto influente na dimensão política refere-se ao fato de que, durante o período militar, todos os municípios da RMS tinham seus prefeitos eleitos indiretamente (exceto o de Vera Cruz). Com isso, havia maior facilidade de imposição da presença da Conder em todos os municípios.

Com o retorno das eleições diretas para prefeito, as duas principais cidades da RMS - Salvador e Camaçari - elegeram candidatos de oposição ao grupo político hegemônico no governo do estado. Em tal período, a Conder foi instrumental para marcar a presença do governo do estado naquelas cidades, principalmente em Salvador, através da execução de obras de grande visibilidade e que envolviam altos investimentos. Com isso, ofuscava-se e dificultava-se a atuação dos partidos de oposição que governavam essas cidades.

Posteriormente, Salvador e os demais municípios da RMS elegeram prefeitos alinhados ao grupo político hegemônico no estado. Foi a partir de então que a Conder deixou de ser um órgão exclusivamente metropolitano e sua jurisdição passou ao âmbito estadual. $O$ quadro político-eleitoral da RMS foi parcialmente modificado com as eleições de 2004, quando três importantes municípios - Salvador, Camaçari e Lauro de Freitas - elegeram prefeitos de oposição ao grupo político até então hegemônico no estado.

Existem ainda constrangimentos não necessariamente político-institucionais mas que também dificultam a construção de mecanismos de cooperação e de coordenação. Pesquisas já realizadas sobre as relações entre o governo do estado e as prefeituras da RMS apontam para a existência dos seguintes constrangimentos: (a) os governos locais da RMS não são (ou não eram) envolvidos no processo decisório sobre ações estaduais que ocorrem nos espaços territoriais dos municípios, o que gera resistências ou omissão das prefeituras quando chamadas a participar de programas e projetos coordenados pelo governo do estado; (b) o envolvimento das prefeituras só ocorre quando existe aporte de recursos específicos para alguma obra ou programa; (c) inexistem estímulos materiais e políticos para que as prefeituras aportem recursos a programas estaduais que ocorrem nos seus territórios, mas que não são por elas coordenados; (d) a manutenção das obras, ou a participação das prefeituras na fase de pós-intervenção de projetos realizados pelo governo do estado, tem sido avaliada como insatisfatória; (e) a capacidade técnica e de gestão dos municípios da RMS é considerada precária; mesmo naqueles que detêm receita orçamentária per capita relativamente alta vis-à-vis outros municípios, não se tem conhecimento da existência de programas de capacitação técnica dos seus quadros, com raras exceções, em geral localizadas na área fazendária; (f) a RMS é marcada por heterogeneidades de toda ordem, entre elas em relação à distribuição dos recursos 
tributários; em termos per capita, por exemplo, Salvador apresenta um dos mais baixos índices da RMS em arrecadação de ICMS, em contraste com São Francisco do Conde, que, com $1 \%$ da população da RMS arrecada $20,4 \%$ do ICMS da região, além se contar com o maior PIB per capita entre todos os municípios brasileiros.

Como se pode apreender da análise acima, na RMS a governança metropolitana (ou a sua falta) apresenta três paradoxos. 0 primeiro é que, a despeito da trajetória histórica da entidade metropolitana e da sua importância relativa no território da RMS e nos seus municípios, essa trajetória não deixou legados indutores da criação de mecanismos de cooperação e de cooperação quando da sua transformação em entidade estadual. O segundo é que, assim como está ocorrendo em outras RMs brasileiras, o governo do estado, a despeito de sua competência constitucional, ainda não inseriu o tema metropolitano na sua agenda. 0 terceiro é que a legislação federal e, mais recentemente, a estadual, tem priorizado a construção de mecanismos de participação societal, na linha de reforço da democracia deliberativa (governança no sentido estrito), mas desconsiderando a construção de mecanismos governamentais de coordenação. ${ }^{14}$

\section{COMENTÁRIOS FINAIS}

Este trabalho discutiu as condições político-institucionais da cooperação e da coordenação nas metrópoles brasileiras em geral e na Região Metropolitana de Salvador, analisando-as à luz do referencial teórico neo-institucionalista sobre as condições de cooperação nas ações coletivas e de coordenação inter e intragovernamental.

O trabalho buscou demonstrar que a formulação de políticas públicas e a gestão dos territórios metropolitanos no Brasil e na RMS não foram desenhadas para incorporar formas cooperativas de gestão do território, nem mecanismos de coordenação. Mostrou também que inexistem instâncias formais ou informais voltadas para a cooperação (nem sequer para a coordenação) entre estado e municípios e/ou entre as diferentes agências do governo estadual, assim como mecanismos que induzam a constituição de redes de relações intergovernamentais capazes de articular as intervenções das três esferas governamentais e do setor privado. Ademais, a constituição de instâncias de intermediação de interesses e a criação das condições institucionais (regras) para a cooperação estão ausentes da agenda do mosaico de atores e agências que atuam nas regiões metropolitanas brasileiras em geral, inclusive na de Salvador. A ausência de mecanismos de cooperação e de coordenação gera, como conseqüência, um vazio institucional de gestão, de governança e de formulação de políticas públicas metropolitanas.

\footnotetext{
${ }^{14}$ Em 12/11/2007, o Governo do Estado da Bahia promulgou a Lei 10.704, criando o ComCidades/BA. Quando constituídos, cada um desses conselhos deverá contar com 61 membros representando 0 governo estadual, os municipais e diversos setores não-governamentais e privados.
} 


\section{REFERÊNCIAS}

AGRANOFF, Robert. Intergovernmental policy management. In: CONFERÊNCIA INTERNACIONAL "WHICH FEDERALISM?" Brindisi-Itália, 12-14 nov., 2003.

ARRETCHE, Marta. Estado federativo e políticas sociais: determinantes da descentralização. São Paulo: Ed. Revan, 2000.

ETZIONI, Amitai. A comparative analysis of complex organizations. New York: Free Press, 1965.

MEDEIROS, Antonio Carlos de. Politics and intergovernmental relations in Brazil, 1964-1982. New York: Garland, 1986.

; SOUZA, Celina. Gestão do território versus estrutura de solidariedade e autoridade. Revista de Administração Pública, Rio de Janeiro, v.27, n.3, p.37-49, 1993.

PRESSMAN, Jeffrey. Federal programs and city politics: the dynamics of the aid process in Oakland. Berkeley: University of California Press, 1975.

OLSON, Mancur. The logic of collective action. Cambridge, Mass: Harvard University Press, 1965.

RIBEIRO, Luiz Cesar de Q. (Org.) Metrópoles: entre a coesão e a fragmentação, a cooperação e o conflito. São Paulo: Ed. Fundação Perseu Abramo; Rio de Janeiro: FASE - Federação de Órgãos para Assistência Social e Educacional, 2004.

SETZLER, Mark. Recursos socioeconômicos, capital sociocultural e conhecimento político como determinantes da formulação de políticas públicas locais no Brasil. Caderno $\mathrm{CRH}$ : revista do Centro de Recursos Humanos da UFBA, Salvador, n.39, p.133-160, 2003.

SOUZA, Celina. Brazilian metropolitan regions: regime change and governance vacuum. Public Administration and Development, [S.I.], v.25, n.4, p.341-350, 2005a.

Tensions between global demands and local needs: urban governance in São Paulo. In: SEGBERS, K.; RAISER S.; VOLKSMANN, K. (Ed.). Public problems-private solutions? Globalizing cities in the south. Aldershot: Ashgate, 2005b. p.363-378,

Regiões metropolitanas: trajetória e influência das escolhas institucionais. In: RIBEIRO, Luiz César de Queiroz (Org.). Metrópoles: entre a coesão e a fragmentação, a cooperação e o conflito. São Paulo: Ed. Fundação Perseu Abramo; Rio de Janeiro: FASE - Federação de Órgãos para Assistência Social e Educacional, 2004. p.61-96 158, 2003.

Regiões metropolitanas: condicionantes do regime político. Lua Nova, São Paulo, n.59, p.137-

. Decentralization, local autonomy and metropolitan influence: the case of Salvador, Brazil". In: ATKINSON, A. et al. (Ed.) The challenge of environmental management in urban areas. Adelshot: Ashgate, 1999. p.251-260,

Constitutional engineering in Brazil: the politics of federalism and decentralization. London: Macmillan; New York: St. Martin's Press, 1997.

Gestão local e gestão metropolitana: um falso dilema? Espaço \& Debates, São Paulo, n.30, p.56-60, 1990.

Metropolização brasileira: uma análise dos anos setenta. Rio de Janeiro: Fundação Getúlio Vargas; Brasília: Conselho Nacional de Desenvolvimento Urbano, 1985.

STREN, Richard. The challenge of urban governance. In: COMMITTEE OF POPULATION (Ed.) Cities transformed: demographic change and its implications in the developing world. Washington, D.C: National Academy Press, 2003. p.355-409. 
Este livro foi composto no formato $17 \times 23 \mathrm{~cm}$. Impresso em papel Alta Alvura $75 \mathrm{~g} / \mathrm{m}^{2}$ no Setor de Reprografia da EDUFBA. Impressão de capa e acabamento da Bigraf. Tiragem de 600 exemplares.

Salvador, 2008. 